\title{
Fire and Explosion Hazards of Oil Shale
}

By Staff, Bureau of Mines

DISTRIBUTION OF THIS DOCUMENT IS UNLIMITED

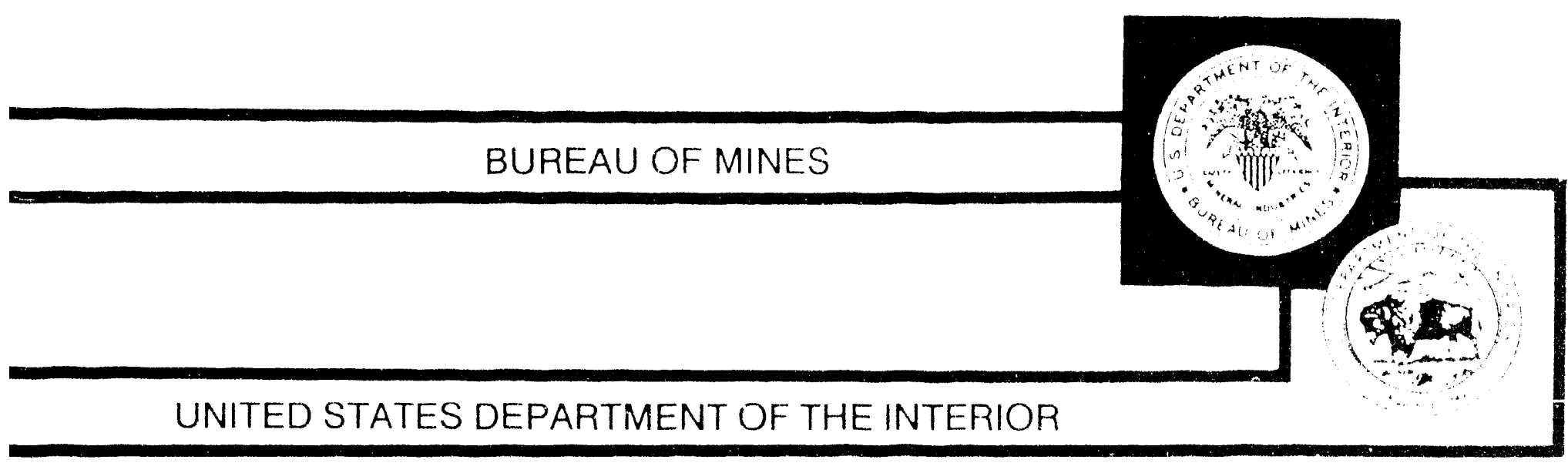


Mission: As the Nation's principal conservation agency, the Department of the Interior has responsibility for most of our nationally-owned public lands and natural and cultural resources. This includes fostering wise use of our land and water resources, protecting our fish and wildlife, preserving the environmental and cultural values of our national parks and historical places, and providing for the enjoyment of life through outdoor recreation. The Department assesses our energy and mineral resources and works to assure that their development is in the best interests of all our people. The Department also promotes the goals of the Take Pride in America campaign by encouraging stewardship and citizen responsibility for the public lands and promoting citizen participation in their care. The Department also has a major responsibility for American Indian reservation communities and for people who live in Island Territories under U.S. Administration. 


\title{
Fire and Explosion Hazards of Oil Shale
}

\author{
By Staff, Bureau of Mines
}

\section{DISCLAIMER}

This report was prepared as an account of work sponsored by an agency of the United States Government. Neither the United States Government nor any agency thereof, nor any of their employees, makes any warranty, express or implied, or assumes any legal liability or responsibility for the accuracy, completeness, or usefulness of any information, apparatus, product, or process disclosed, or represents that its use would not infringe privately owned rights. Reference herein to any specific commercial product, process, or service by trade name, trademark, manufacturer, or otherwise does not necessarily constitute or imply its endorsement, recommendation, or favoring by the United States Government or any agency thereof. The views and opinions of authors expressed herein do not necessarily state or reflect those of the United States Government or any agency thereof.

UNITED STATES DEPARTMENT OF THE INTERIOR

Manuel Lujan, Jr., Secretary

BUREAU OF MINES

T S Ary, Director 
Library of Congress (ataloging in Publication Data

Fire and explosion hazards of oil shale.

(Report of investigations; 9281 )

Includes bihlingraphics.

Supt of Docs. no.: I 2823:9281.

1. Oil-shales-lïre and fire prevention. 2. Dust explosion. 3. Oil-shales-lesting. I. United States. Burcau of Miries. II. Series: Report of investigations (Lnited Statcs. Burcau of Mines):?281.

TN2.3.U4.3

ITN.31:;

$0.22 \times[0.22 .8]$

$88-(60)(0.3+1$ 


\section{CONTENTS}

\section{PART 1: EXPLOSIBILITY AND IGNITABILITY OF OIL SHALE DUST CLOUDS}

Abritact.

Introduction

Apparates and experimental method.

Oil shale and eomparison dusts

z()-1. explovibility ext chamber

1.2-1 ignitabilis fumas.

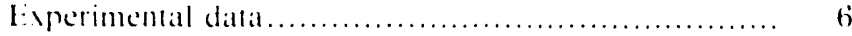

Autoignition temperatures ...............................

lgnition chergics...................................

Evplosibility dalat............................ i

Particle sice variable and microscopic observattions ..... 9

Discussion and conclusion ............................ 11

References........................................ 12

\section{PART 2: FIRE HAZARDS OF OIL SHALE DUST LAYERS ON HOT SURFACES}

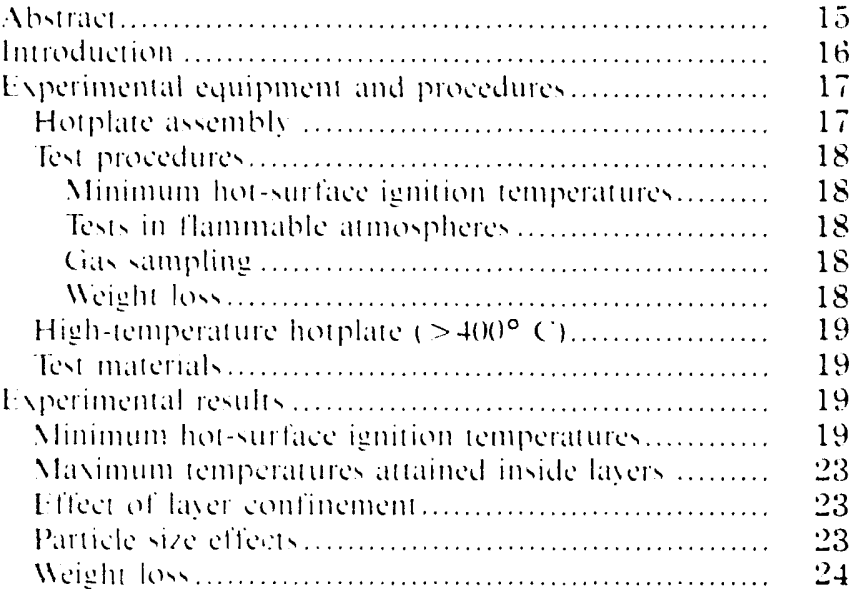

(ian simples ..................................... 25

Sprinkle lests ...................................... 26

Fests in llammable atmospheres.................... 26

High-temperature hotplate $(>f()))^{\circ}($ ) $\ldots \ldots \ldots \ldots \ldots \ldots .27$

Discussion of results................................ 27

Minimum hos-surfate ignition lemperatures.......... 27

Masimum temperatures attanined inside lavers ........ 28

Efled of laser confinement .......................... 29

Particle sise eftects................................ 29

llight loss........................................ 30

(ias silmples ..................................... 30

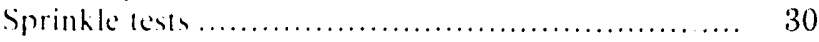

Tests in llammable atmospheres .................... 31

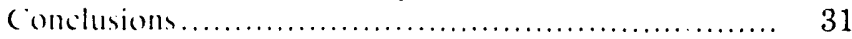

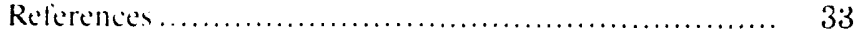

Appendix.-Maximum lemperatures atlained inside various lasers of oil shale and coal dusts ............. 34

\section{PART 3: FLAMMABILITY AND SPONTANEOUS COMBUSTION POTENTIAL OF COARSE OIL SHALE AND EFFECTIVE METHODS OF EXTINGUISHMENT}

Ib-tract

InIfoduction)

t: yerimemal procedures

pile somstrictom and imstumentaion

Ignition voures.

L) \inguivhing ageml.

1. Yporimental comb

Rubtric lite 1

Rubble line 2

Rubble tire?

Rublels tire +
Summary and eonclusions

Slow-heating test

Ignilion.

Lotinguishment

kic! findings

Relerences

Appendis A. - Nodel for heating and self-hcating..... 57

Appendis B. - Model for cooling ....................... 59

Appendis ( . - Strategy for fighting oil shale lïes...... 61

Appendis D. - List of symbols ....................... 63 


\section{ILLUSTRATIONS}

1-1. 2(1)-1 dun explosibility test chamber

1-2. 1.2-1 ignitability furnace

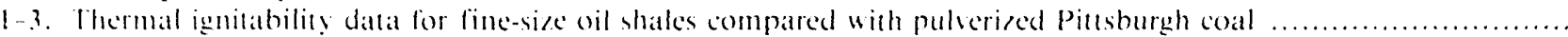

1-4. Thermal ignitability data for coarse-size oil shale compared with fine-sie oil shate of same assay ..................

1 . . Eyplosibility data for finc oil shales compared with Pittsburgh coal, sulfide ore, and anthracite coal of similar size ...

1-6. Explosibility data for coarse and tine sizes of 33 -gal ton oil shale

1-7. Heating value for oil shale as function of particle size compared with heating value and wolatile content of Pittsburgh coat

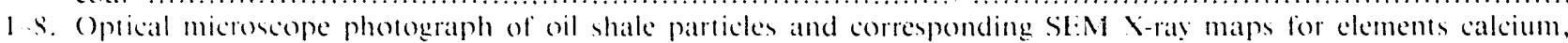
silicon, and aluminum

$2-1$. Sichematic of hoplatic

2-2. Hotplate cest apparatus in laboratory hood

2-3. Enclonure for liammable atmosphere in position on hotplate

2-4. Cemperature-lime profiles for 12.7 -mm-thick layers of $2\left(\right.$-gal ton oil shale all hotplate surface temperatures of $2800^{\circ}$ and 29()$^{\circ}($

2-5. Temperature-time profiles for 12.7-mm-thick layers of fine oil shale and coal dusts at minimum hotplate surface ignition lemperatlures

2-6. Femperature-time profiles for 12.7 -mm-thich lavers of 20 -gal/ton oil shale at sereral hotplate surface temperatures ....

2.7. Temperalture-time profiles for 6.4-mm-thick lavers of 20- and 33-gal/1on oil shales and Pittsburgh coal at minimum hotplate surfice ignition temperatures

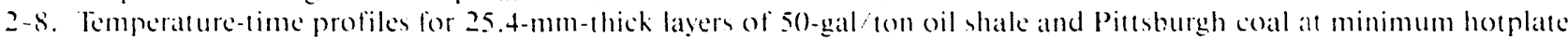
surfice ignition cemperatures

2-9. Temperature-time profiles within laver and just under surface of 38.1 -mm-1hick layer of 33 -gal ton oil shate at minimum hotplate surface ignition temperature of $210^{\circ} C^{\circ}$

2-10. Temperature-time profile for 25.4 -mm-thick laver of $5\left(1-\right.$ gal ton oil shale at hotplate surface temperature of $3800^{\circ} \mathrm{C}(. .$.

2-11. Minimum hotplate surface ignition temperatures for fine oil shate and Piltsburgh coal dusts as a function of laver thichnems

2-12. Typical hotplate est howing ignition process in 12.7 -mm-thick layer of 50 -gal ton oil shale dust

2-13. Femperature-1ime protiles lor 6.4 -mm-l hick layers of 50 -gal ton oil shake at ewo hotplate surface temperatures ....

2-14. Minimum hotplate surface ignition temperatures for finc oil shale and pitrsburgh coal dusts as a function of laver thichness. inciuding values from sprinkle tests

2.15. Semilog plots of laver thichness versus reciprocal of ninimum ignition temperature for fine oil shale and Pittsburgh coial dusts

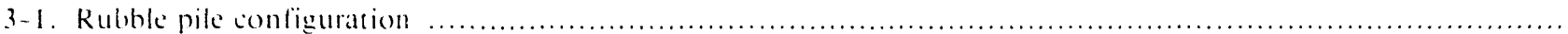

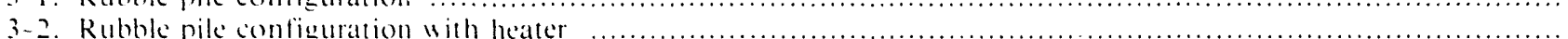

3-3. Thermocouple locations for rubble fïre 1

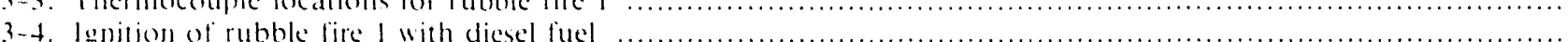

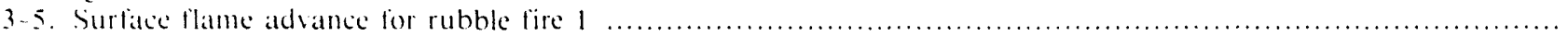

$3-6$. Burning of large lumpe of shale in rubble lire?

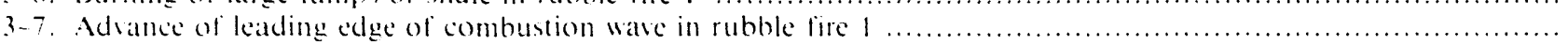

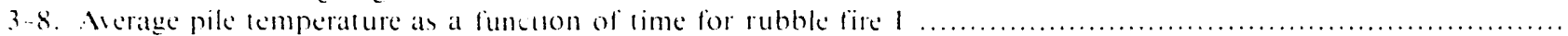

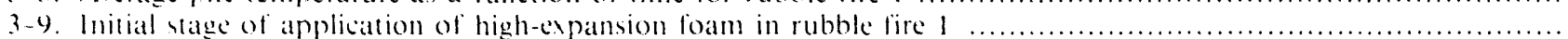

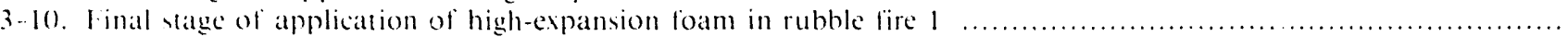

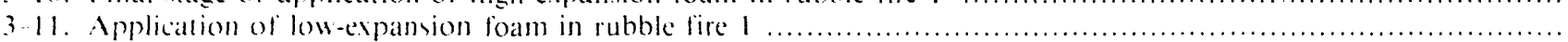

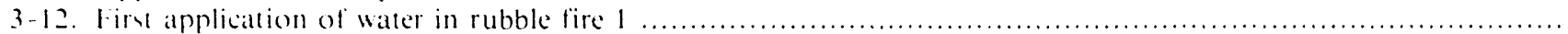

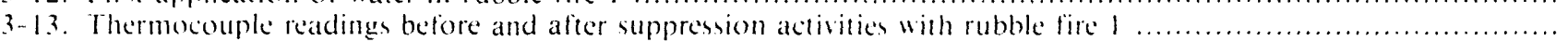

3-14. Thermocouple locations for rubble tïre 2

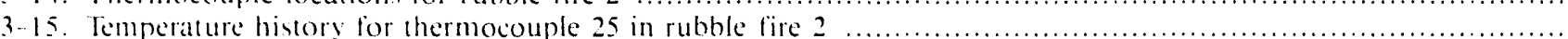

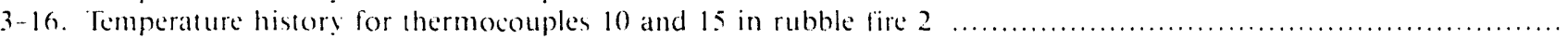

3. 17. Ienition of rubble lïe 2 with diesel fuel

3-18. Surface flame adiance in rubble fire 2

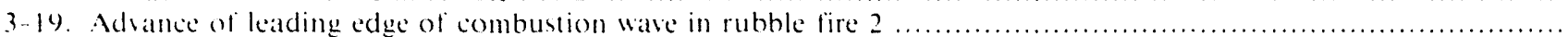

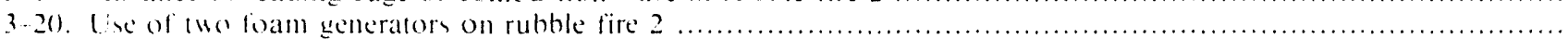

3-21. Average pile temperature as a function of time lor rubble fïre 2

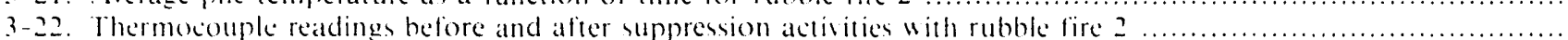

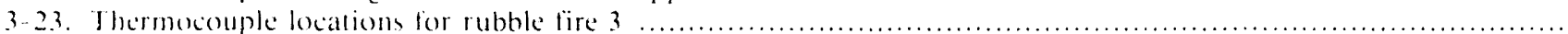

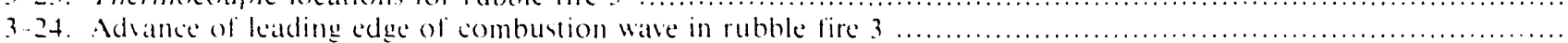

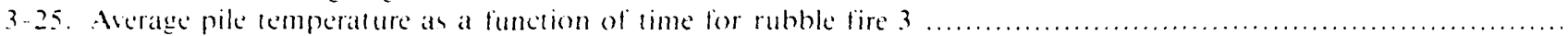

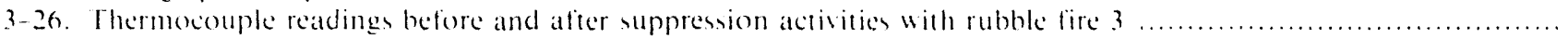

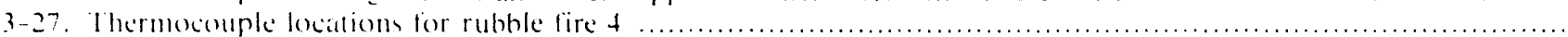

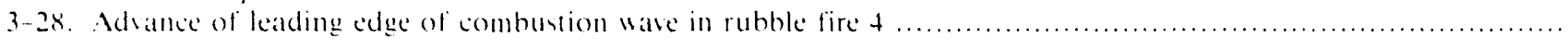

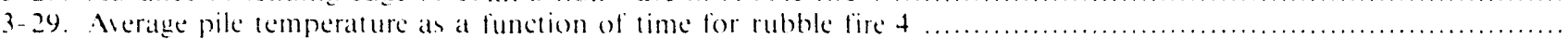

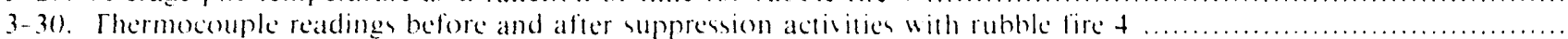

A-1. Temperature response and drum temperature 
TABLES

1 1. Propertien of ail hale and comparison dusts

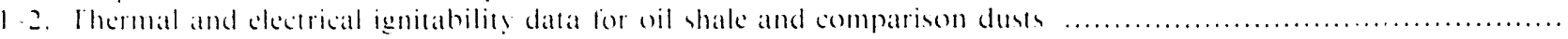

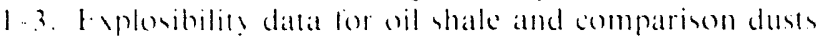

2-1. Analswe cit sit hale and coal duste...

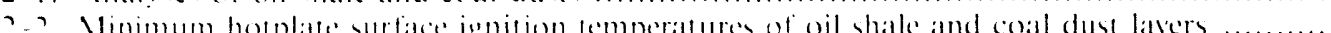

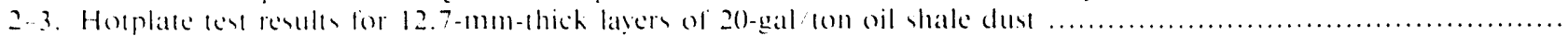

2-4. Masimum liner comperatures atlatined in larious cess

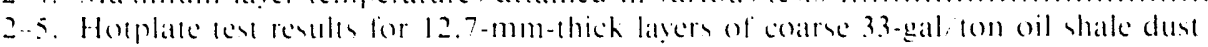

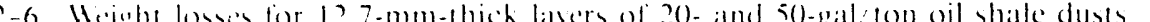

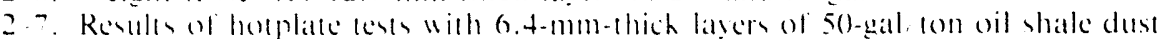

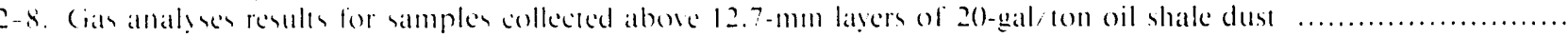

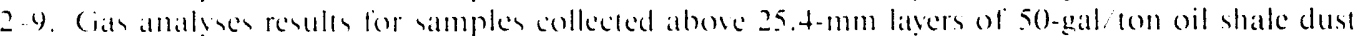

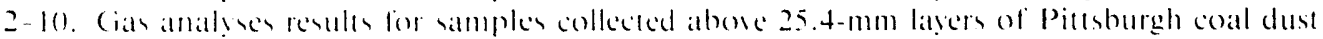

2-11. (ian analines resuld for samples collected above heated layer of s()-galiton oil shale and piltsburgh coal inside flammable gar enclousure

2-12. Masimum rise in temperature (Jlmas) imside laters heated all their respective minimum hot-surface ignition temperaluses

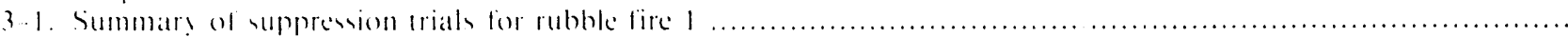

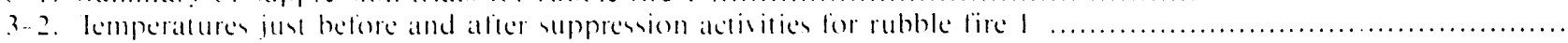

3. 3. Slou-heating ken data

3. Summars of suppresion triale for rubble fire 2

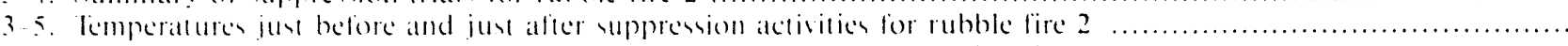

3-6. Eomperalures just belore and just after suppression aldisities for rubble lire 3

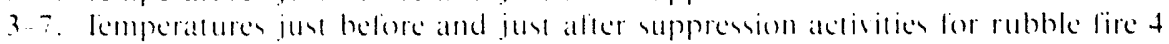

3-8. Eemperature redection during suppression of rubhle tite 1

3.9. Comperature reduction during suppresion of rubble lire 2

3 10. Iemperature adedetion during suppression of rubble lite 3

3 11. Kemperature redaction during suppression of rubble lite 4

1. Pmencial properties ol oil shate uned in models

1 2. llammal rmatwa!

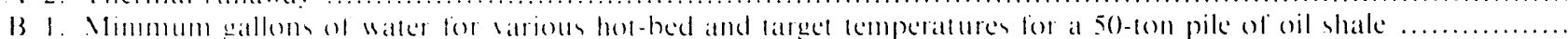




\section{UNIT OF MEASURE ABBREVIATIONS USED IN THIS REPORT}

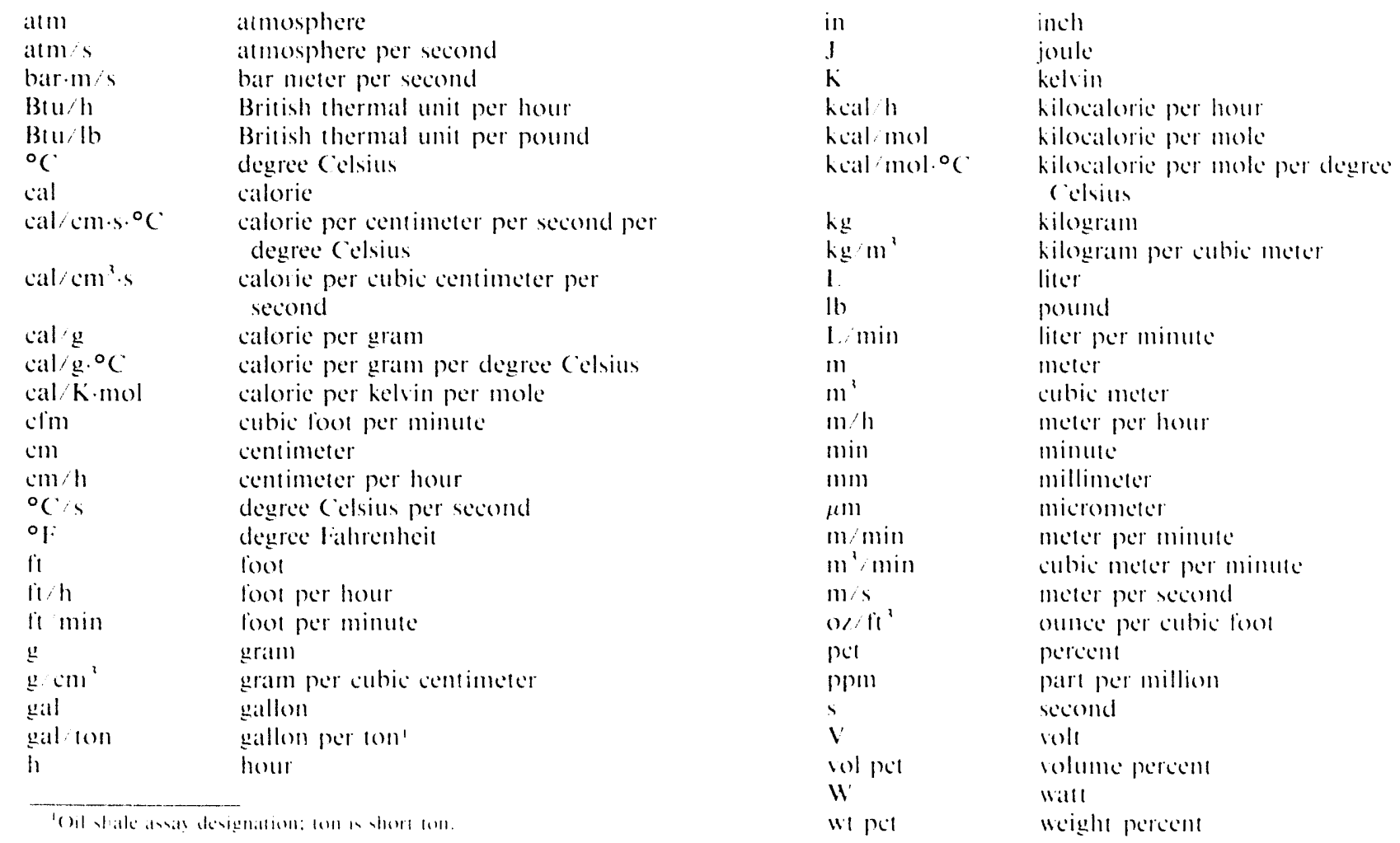




\title{
FIRE AND EXPLOSION HAZARDS OF OIL SHALES
}

\author{
By Staff, U.S. Bureau of Mines
}

\begin{abstract}
This L.S. Bureau of Mlines publication presents the results of insestigations into the fire and explosion hazards of oil shale rocks and dust. Three areas have been examined: the explosibility and ignitahility of oil shale dust clouds, the fire hazards of oil shale dust layers on hot surfaces, and the ignitability and exinguishment of oil shale rubble piles.
\end{abstract}




\section{INTRODUCTION}

()il shale can presem a salely ha/ard to those involsed in its mining, processing. or stoch piling. In mining and processing, oil shale dust is gentrated, dispersing in the air and depositing on equipment surfaces. A sufficiently high concentration of oil shate dust in the air ean propagate an explosion if a strong ignition source is present. (Oil shale dust on the surfices of equipment can undergo combustion if the temperature of a surface is sufficienty hot. Large quantities of oil shake, in stochpiles for example, represent another fire hazard, if ignited spontaneously or by an outside ignition souree.

As part of its program to improve personnel safety in the minerals industry, the U.S. Bureau of Mines examined these atspects of oil shale mining in order to establish eriteria for safety. This report is divided into three parts. Part 1 presents results from studies on the explosibility and ignitability of line and coarse oil shale dust clouds, using a 20-1. laboratory chamber and a 1.2-1. furnace. Part 2 reports on the hazards of oil shale dust layers on hot surlaces. A hotplate was used to determine minimum hot-surface ignition temperatures. Part 3 covers the ignition and extinguishment of large oil shale rubble piles. The oil shales that were lested eame from the cireen River Formation in the Western United States.

This work was done with financial support from the Colorado Mining Association and the U.S. Department of Energy, under memorandums of agreement 14-(39-0)50-3285, 14-09-(0)50-3286, and 14-09-0(070-3291. 


\title{
PART 1: EXPLOSIBILITY AND IGNITABILITY OF OIL SHALE DUST CLOUDS
}

\author{
By Kenneth L.. Cashdollar, ${ }^{1}$ Martin Hertzberg, ${ }^{2}$ and Ronald S. Conti ${ }^{3}$
}

\begin{abstract}
The U.S. Bureau of Mines investigated the explosion hazards of fine and coarse oil shale dust cloudh. Six grader of tine dust of varying oil assay (20 to 55 gal/ton) but with similar i/e distributions were studied in a $20-\mathrm{L}$. explosibility chamber and a 1.2-L. ignitability furnace. Also studied was a coarse oil shale dust with an assay of 33 gal/ton. For comparison, Pittsburgh Seam bituminous coal, gilsonite, sulfide ore, and anthracite coal were also tereted.

The fean limits of flammability saried inversely with oil assay, and all grades of the fine thale dus were capable of generating explosions at concentrations above their respective lean limits. Howerer, even the $5($-gal/ton fine shale dust was less hazardous than a similar size of Pilt hurgh bituminoun coil dust in the 2()-L. chamber tests. The coarse shale dust had a much higher leall flammable limit and a lower maximum pressure and rate of pressure rise than the similar-assay line shate dust. The shales were at least an order of magnitude less ignitable by electric sparks than the bituminous coal. The shale dust clouds were, however, somewhat more carils ignited thermally than the coal.
\end{abstract}

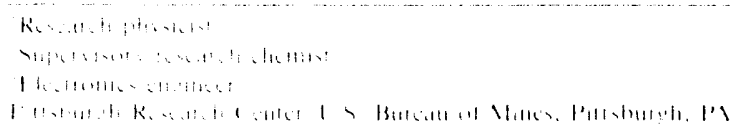




\section{INTRODUCTION}

For a number of years, the Bureau has conducted laboratory and full-scale mine experiments on the explosion hasards involved in the mining and processing of oil shate dusts. The earliest work was done by Allison and Batler $(/)^{\text {t who }}$ showed that oil shale dust could indeed propagate an explosion. More recent and more comprehensive mine testing of the explosibility of oil shate dusts was conducted by Richmond (2-5). Bureau research also involsed the monitoring of methane emicsions in oil shale mines and the study of large oil shale rubble fires $(3,5-6)$.

Supplementing this work, a Bureau contractor (7-9) evaluated the fire and explosion hazards of oil shale mining. Various accident seenarios were postulated, mine dust loadings were measured, and laboratory lests were conducted (7-12). The laboratory dust flammability testing under the contrace used a Hartmann apparatus (1/3) and found that oil shale dust could be ignited only after altering the standard procedures ( 7 . 12). Bureau research (14) has shown that the 1.2-L. Hartmann apparatus has several severe deficiencies, such ats nonuniform dust dispersion and itadequate ignition energy, which limit its usefulness, particularly for hard-to-ignite dusts such as oil shale.

The Bureau's recent laboratory dust flammability testing has been conducted in a $20-\mathrm{L}$. chamber $(15)$ in which optical probes are used to monitor the uniformity of the dust dispersion and strong chemical ignitors are used to intiate the explosion tests. The explosibility data reported here are from this 2()-1 chamber. Some of the data for the fine-sise oil shale duss were also presented at the 17 h (O) Shale Symmosium (16).
There are 1 wo aspects to the explosion hatard of dests. One is related to the probability of having a flammable volume of dust dispersed in air. To evaluate this ha/ard, it is necessalls to measure the lean concentration limit of flammability for the dust and to compare that number with the actual dust loading in the mine volune. The second aspect is related to the probability of igniting the flammable dust cloud. To evaluate this, the minimum thermal autoignition temperature and minimum ignition energy can be measured. If both a flammable dust cloud and a sufficiently strong ignition source are present, an explosion will oceur, and the explosion pressure and rate of pressure rise will provide a measure of the severity of the explosion. In part 1 of this report, the terms "flammability" and "explosibility" are both used to refer to the ability of an airborne dust sloud to propagate a flame after it hais been initiated by a sufficiently strong ignition source. The ferms refer to a rapid deflagration and not a detonation.

Because of the complexity and large seale of full-scalc experimental mine lests, personnel and time demands are considerable for each test. Laboratory tests in the 20)1. chamber can be conducted much more easily and quickly. Various comparison experiments (17-19) have shown good agrement between laboratory and mine tests. Therefore, the laboratory chambers are now used for preliminary sereening before full-scale mine tests are conducted. Full-scale mine lests are, however, still essential for the final esaluation of the true explosion hazard.

\section{APPARATUS AND EXPERIMENTAL METHOD}

\section{OIL SHALE AND COMPARISON DUSTS}

The properties and chatatererstics of the finte- and coarsesiec oil thate and comparisent dusts are hown in lable $1-1$. In the firs column of the lable is an idemsilication mumber used

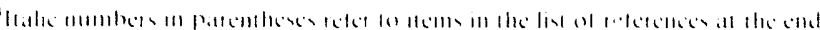
11 P.111 in previous Bureau publications $(2,5,16)$ for the same sil shale dusts. The fischer atssays (20) have uncertainties of 1 to 3 gal ton. Batsed on additional datal, the fischer assates have been reveded slightly from the values in earlier reports. The perechtage of volatiles is the sum of the vil and gats amounts from the fischer assays (5). The heating valtes were measured in an adiabatic homb calorimeter (2/). The sise analyses are

Table 1-1._Properties of oil shale and comparison dusts

\begin{tabular}{|c|c|c|c|c|c|c|c|}
\hline \multirow{2}{*}{$\begin{array}{l}\text { Dust } \\
\text { 'ample' }\end{array}$} & \multirow{2}{*}{$\begin{array}{c}\text { Fischer assay: } \\
\text { gal/ton }\end{array}$} & \multirow{2}{*}{$\begin{array}{c}\text { Volatility. } \\
\text { pct }\end{array}$} & \multicolumn{2}{|c|}{ Heatıng value } & \multicolumn{2}{|c|}{ Mean diameler, „m } & \multirow{2}{*}{$\begin{array}{l}\text { Minus } 200 \\
\text { mesh. w1 pct }\end{array}$} \\
\hline & & & $B(u / l b$ & $\mathrm{cal} / \mathrm{g}$ & Surface $\left(\bar{D}_{.}\right)$ & $\operatorname{Mass}\left(\overline{\mathrm{D}}_{n}\right)$ & \\
\hline \multicolumn{8}{|c|}{ FINE-SIZE DUST } \\
\hline \multicolumn{8}{|l|}{ Oil shale. } \\
\hline 5082 & 20 & 9 & 1.810 & 1.010 & 14 & 37 & 85 \\
\hline $6 i 14$ & 23 & 10 & 2.140 & 1.190 & 16 & 114 & 57 \\
\hline 6238 & 33 & 15 & 3.230 & 1.730 & 12 & 56 & 72 \\
\hline 0000 & 42 & 19 & 4.100 & 2.280 & 17 & 43 & 84 \\
\hline 5084 & 50 & 22 & 4.700 & 2.610 & 17 & 51 & 78 \\
\hline $5777 \cdot 5$ & 35 & 25 & 5.260 & 2.920 & 21 & 93 & 60 \\
\hline Anthracile coal & NAP & 5 & 12.860 & 7.140 & 13 & 37 & 77 \\
\hline Sulfide ore & NAp & NAP & 2,000 & 1.100 & 18 & 40 & 81 \\
\hline Pittsburghts coal & NAp & 37 & 13.800 & 7.670 & 32 & 50 & 80 \\
\hline Gitsonite & $N A_{p}$ & 85 & 17.770 & 9.870 & 24 & 54 & 72 \\
\hline \multicolumn{8}{|c|}{ COARSE SIZE DUST } \\
\hline Oil shale 5933 & 33 & 15 & 3.190 & 1.770 & 55 & 310 & 27 \\
\hline Pittsburgh coal & $N A p$ & 37 & 14.040 & 7.800 & 90 & 325 & 21 \\
\hline
\end{tabular}

NAu Not applicable

Oll shate identifica ton numbers were used in previous Bureatu publica'ıons (2. 5. 16)

To corivert to liters per metric ton. multiply by 417 
from a combination of sonic sieving data and Coulter counter data (electrolytic conductivity through a small orifice). For the Coulter data, the dusts were dispersed in isopropyl alcohol. The symbol $\bar{D}$, represents the surface mean diameter, and $\bar{D}_{1 "}$ is the volume or mass mean diameter. The weight percent through a 200-mesh sieve is listed in the last column.

Four advitional fine-size dusts were studied for comparison with the fine oil shales; they are also listed in table $1-1$. The volatilities and heating values for the coals and gilsonite were measured by the standard ASTM methods (2l). The mean particic sizes are similar to those of the shales. Pittsburgh Seam pulverized bituminous coal was used for comparison because of the large amount of practical data on its explosion hazards in the coal mining and electric power industries. Gilsonite (asphaltite or uintahite) is a mined asphaltic material that is even more hazardous than coal. An anthracite coal was chosen ais a material that has a long mining history with no record of any pure dust explosion (22). A sulfide ore (about 40 pct sulfur) was chosen as a material that is difficult to ignite but that has caused secondary explosions during mine blasting operations $(23-24)$.

The properties and characteristics of the coarse oil shale and Pittsburgh coal comparison dusts are shown at the bottom of table $1-1$. The coarse coal was 99 pet minus 20 mesh and 21 pct minus 200 mesh. The coarse oil shale was 89 pet minus 20 mesh and 27 pct minus 200 mesh.

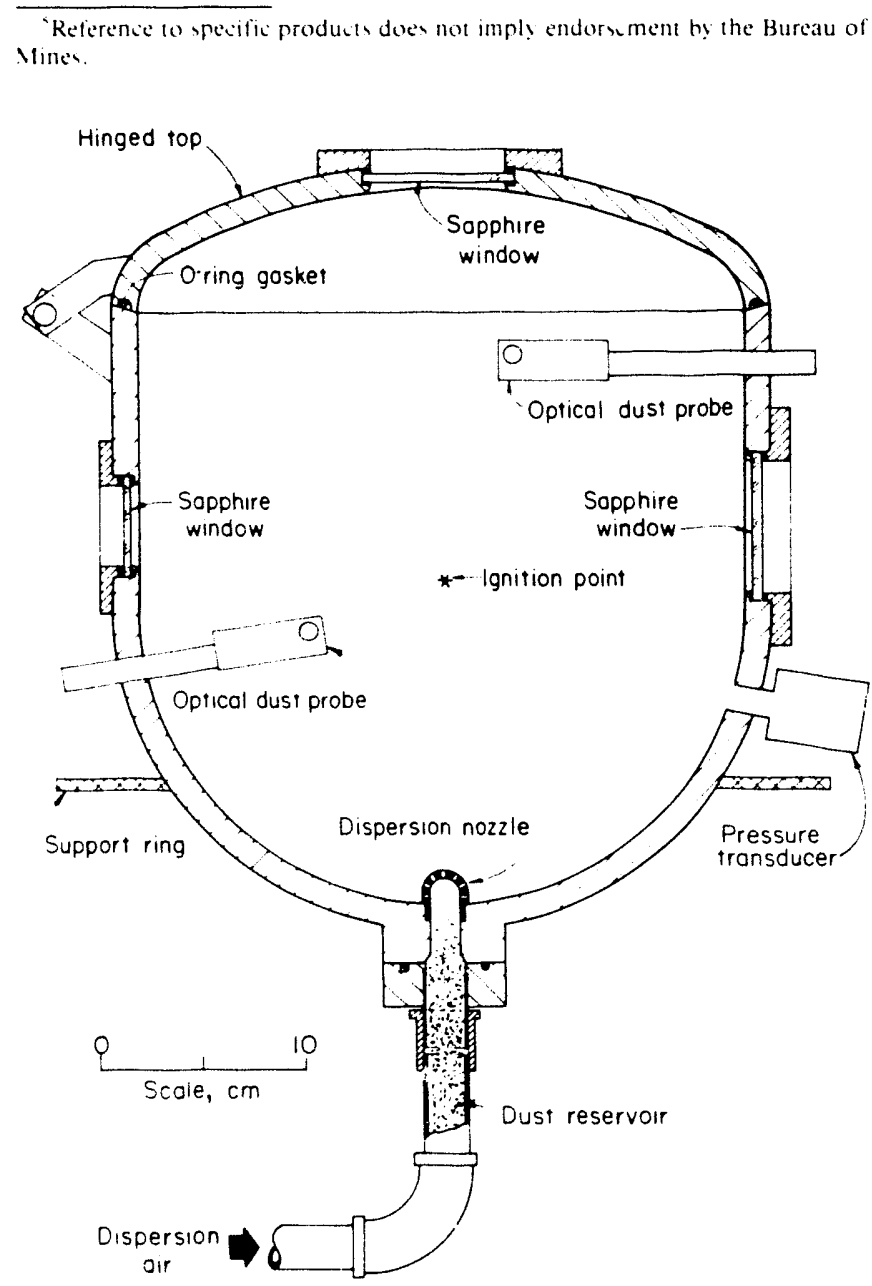

Figure 1-1.-20-L dust explosibility test chamber.

\section{0-L EXPLOSIBILITY TEST CHAMBER}

The 20-L laboratory chamber (15) used for the flammability and ignitability testing of the dusts is shown in figure $1-1$. The optical dust probes $(25-26)$ are used to measure the dust dispersion uniformity. The dust is placed in the reservoir at the bottom of the chamber and is dispersed through the holes in the nozzle by a blast of air from a reserve tank (not shown). The standard procedure is to partially evacuate the chamber to $0.1 \mathrm{~atm}$ absolute so that the blast of air (which disperses the dust) raises the chamber pressure to 1 atm absolute at ignition. Various ignition sources, such as electric sparks, chemical matches, and strong chemical ignitors, can be used. A more detailed description of the experimental procedures can be found in reference 15 .

\section{2-L IGNITABILITY FURNACE}

The 1.2-L furnace (27) used to measure the thermal and electrical : gnitability of the dusts is shown in figure 1-2. For the thermal ignition tests, the furnace is 'et at a predetermined

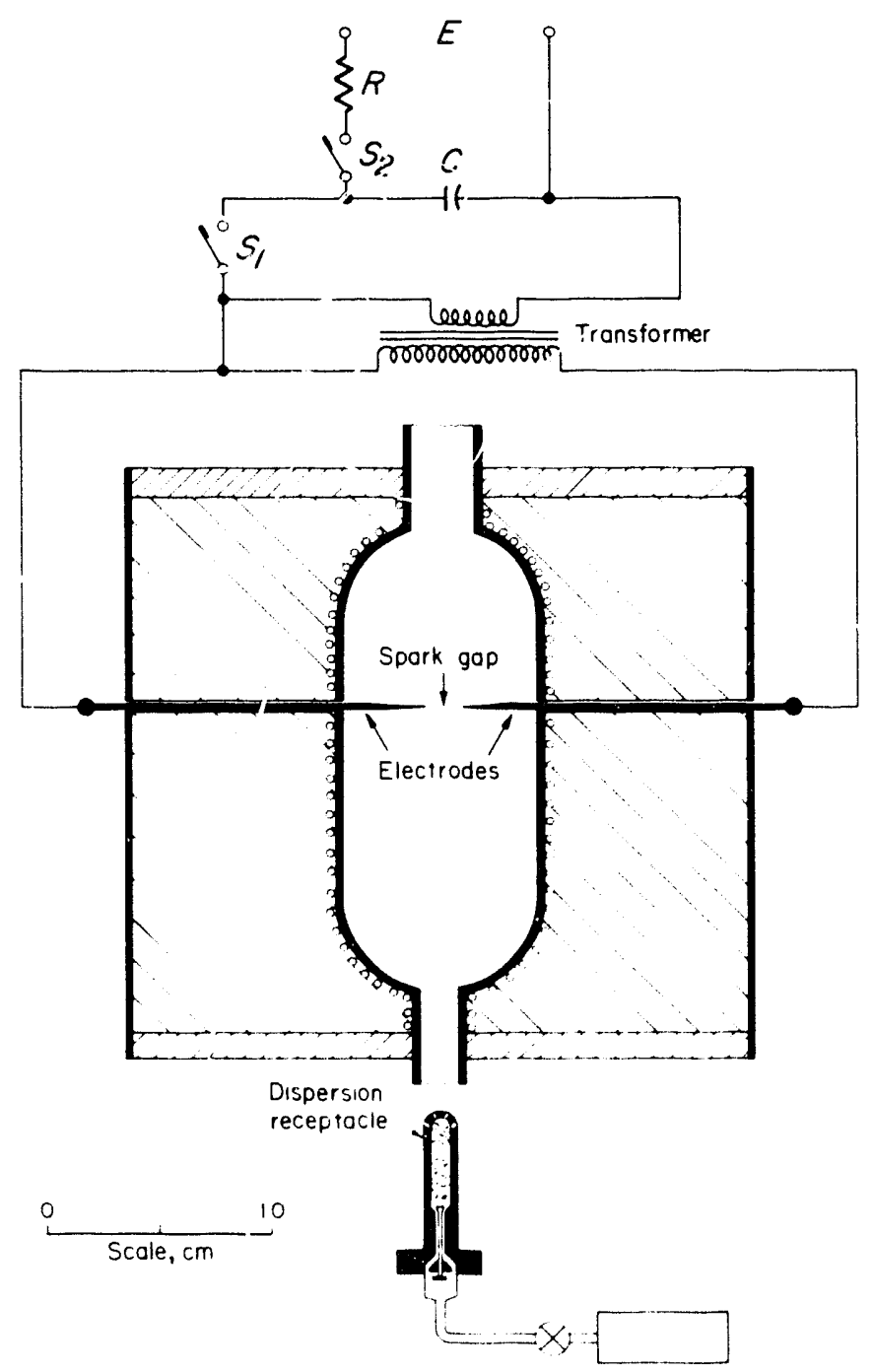

Figure 1-2. -1.2. $\mathrm{L}$ ignitability furnace. $(C=$ capacitor; $E=$ charging voltage; $1 \mathcal{L}=$ resistor; $S=$ switch.) 
temperature and the dust is placed in the dispersion receptacle. Then the receptacle is quickly inserted into the bottom of the furnace, and an air blast from the reservoir disperses the dust into the furnace. A fiberglass filter diaphragm on the top of the furnace confines the dust so that its concentration is controlled. The maximum time of exposure of the dust cloud to the furnace temperature is at least several seconds, after which the dust begins to settle out. The criteria for ignition are that the diaphragm rupture and that flame be observed emitting from the top of the furnace. Because of its larger volume, more uniform dispersion, and longer residence time, the 1.2-L furnace generally gives somewhat lower minimum autoignition temperatures (27) than does the 0.3-L GodbertGreenwald furnace (13) used in earlier Bureau studies.

The electricai circuit shown in figure 1-2 was not a part of the system during the thermal ignitability testing, but it was used for spark ignitability testing $(28-29)$ in the furnace at ambient temperature and at elevated temperatures below the autoignition temperature of the dust cloud. A similar spark ignition circuit was also used in the 20 - $\mathrm{L}$ chamber for ignitability testing at ambient temperature.

\section{EXPERIMENTAL DATA}

\section{AUITOIGNITION TEMPERATURES}

Some of the thermal autoignition data for the fine oil shale and Pittsburgh coal dusts are shown in figure $1-3$. The areas above and to the right of the curves represent the combinations of teinperatures and dust cloud concentrations that will thermally autoignite in the 1.2-L furnace. The areas below the curves represent combinations that will not ignite thermally, although dusts in this region might deflagrate if initiated by a point ignition source such as a spark or chemical match flame. Both the low-grade $(20-$ to 23 -galiton) and high-grade (50- to 55-gal/ton) oil shales have slightly lower rninimum autoignition temperatures (AIT) than the Pittsburgh coal dust. (The AIT is sometimes also referred to as the "cloud ignition temperature.") The rich oil shale reaches its minimum AIT at about the same concentration as the Pittsburgh coal, but the 20- to 23-gal/ton shale reaches its minimum AIT at a significantly higher concentration. The minimum AIT's, $475^{\circ}$ to $500^{\circ} \mathrm{C}$, measured for oil shales in the 1.2-L furnace are significantly lower than the $560^{\circ}$ to $620^{\circ} \mathrm{C}$ minimum AIT's reported previously for the shales in the Godbert-Greenwald furnace (12).

The complete data for the minimum AIT's for the fine oil shales and the comparison dusts are shown in table 1-2. The oil shales have minimum AIT's similar to that of gilsonite, somewhat lower than those of Pittsburgh coal and the sulfide ore. The anthracite coal dust has a much higher AIT of $675^{\circ} \mathrm{C}$.

The thermal ignitability data for the 33-gal/ton coarsesize oil shale dust are compared with those for the fine-size shale of the same assay in figure 1-4 and table 1-2. The minimum AIT for the coarse oil shale is $525^{\circ} \mathrm{C}$, only slightly higher than that of the fine shale. However, the minimum AIT is reached at a much higher concentration for the coarse-size shale. The coarse Pittsburgh coal dust was also tested in the 1.2-L furnace. Its AIT is $575^{\circ} \mathrm{C}$, slightly higher than the value for the fine-size Pittsburgh coal.

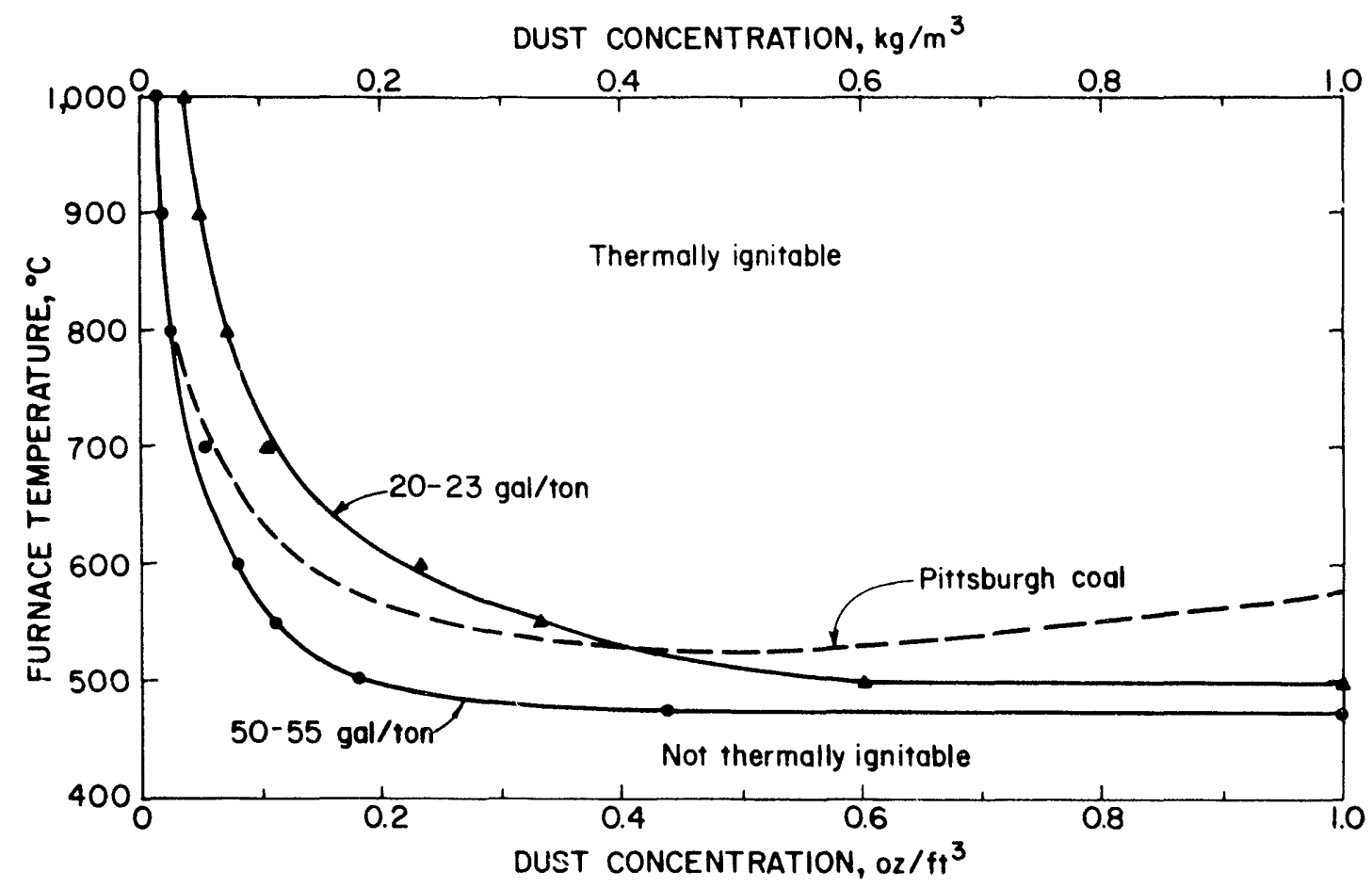

Figure 1-3.-Therma! ignitability data for tine-size oil shales compared with pulverized Pittstuirgh coat. 


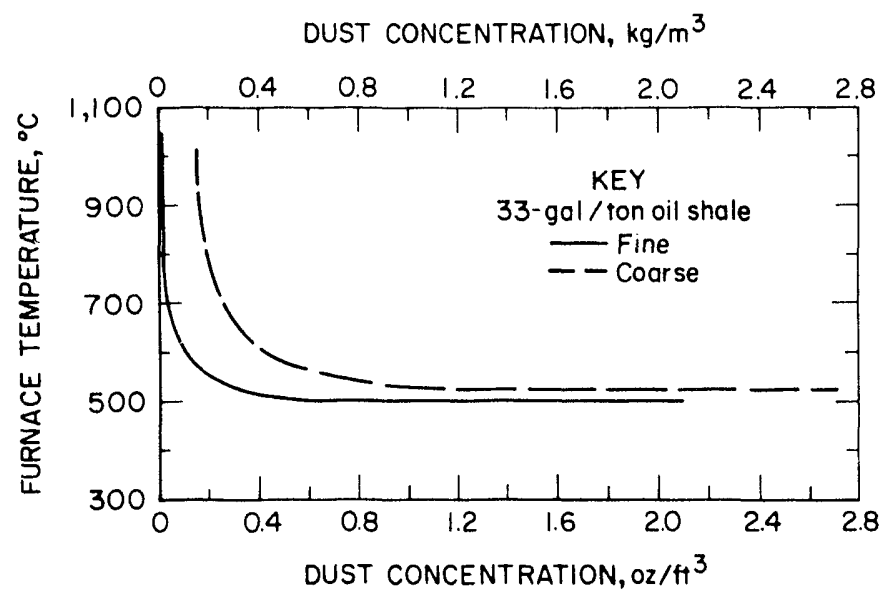

Figure 1-4.-Thermal ignitability data for coarse-size oil shale compared with fine-size oil shale of same assay.

Table 1-2. - Thermal and electrical ignitability data for oil shale and comparison dusts

\begin{tabular}{|c|c|c|c|}
\hline \multirow{2}{*}{$\begin{array}{l}\text { Dust } \\
\text { sample }\end{array}$} & \multirow{2}{*}{$\begin{array}{l}\text { Minimum } \\
\text { AIT, }{ }^{\circ} \mathrm{C}\end{array}$} & \multicolumn{2}{|c|}{$\begin{array}{c}\text { Room-temperature } \\
\text { minimum spark energy, } \mathrm{J}\end{array}$} \\
\hline & & Stored, $1 / 2 \mathrm{CE}^{2}$ & Effective, $2.5 \vee \Delta p$ \\
\hline \multicolumn{4}{|c|}{ FINE-SIZE DUST } \\
\hline \multicolumn{4}{|l|}{ Oil shale: } \\
\hline 20 -gal/ton ................... & 500 & - & - \\
\hline 23-gal/ton .................... & 500 & - & - \\
\hline 33-gal/ton ............... & 500 & - & - \\
\hline 42-gal/ton ............... & 500 & $\mathrm{NI}$ & NI \\
\hline 50-gal/ton ................. & 475 & $80-100$ & $1-2$ \\
\hline Anthracite coal. & 675 & - & - \\
\hline Sulfide ore & 550 & - & - \\
\hline Pittsburgh coal .................... & 540 & .310 & .070 \\
\hline Gilsonite ................... & 490 & .140 & .030 \\
\hline \multicolumn{4}{|c|}{ COARSE-SIZE DUST } \\
\hline Oil shale: $33-\mathrm{gal} / \mathrm{ton} .$. & 525 & - & - \\
\hline Pittsburgh coal ........... & 575 & - & - \\
\hline
\end{tabular}

NOTE.-Dashes indicate no data were obtained.

\section{IGNITION ENERGIES}

The minimum spark ignition energies for the fine oil shales were measured at room temperature in the 1.2-L furnace and $20-\mathrm{L}$ chamber. The minimum ignition energy is generally observed to be apparatus dependent because it is a function of the turbulence level generated by the dust dispersion process as well as the circuit efficiency for transferring stored electrical energy into the gas in the spark gap (29). Therefore, the values reported here should be considered only as relative values for comparing different dusts and not as absolute minimum values. Lower turbulence levels than those used here would probably result in lower minimum ignition energies. In industry, turbulence levels may vary over a wide range, depending on how the dust is dispersed. The data reported in table 1-2 are mainly from the 20 - $\mathrm{L}$ chamber; the minimum values from the 1.2-L furnace were about the same for the shale but larger in the cases of the Pittsburgh coal and gilsonite. The data are reported both as the stored energy on the capacitor, $1 / 2 \mathrm{CE}^{2}$, where $C$ is the capacitance and $F$ is the voltage, and also as the effective energy deposited into the gas in the spark gap. To compare different types of ignition sources, the effective energy of each is obtained by measuring the pressure rise, $\Delta p$, due to the ignition source by isself in a fixed volume V. For the sparks, the effective energy is defined (28-29) as $2.5 \mathrm{~V} \Delta \mathrm{p}$.

For either the stored or effective minimum ignition energy, even the richest oil shale tested is at least an order of magnitude more difficult to ignite than the Pittsburgh coal, which is itself somewhat more difficult to ignite than gilsonite. The 42-gal/ton shale could not be ignited at ambient temperature by the strongest spark available ( 1 to $2 \mathrm{~J}$ effective energy). At above-ambient temperatures of $100^{\circ}$ to $200^{\circ} \mathrm{C}$, this shale could easily be ignited by the $1-$ to $2-\mathrm{J}$ spark. This lowering of the minimum ignition energy at elevated tamperatures has been discussed previously $(27-29)$. The 23 - gal/ton oil shale could be ignited only with a very strong chemical ignitor. Even a chemical ignitor with a calorimetric energy of $2,500 \mathrm{~J}$ and a $2.5 \mathrm{~V} \Delta \mathrm{p}$ energy of about $1,500 \mathrm{~J}$ was not able to ignite a uniformly dispersed cloud; however, one with a calorimetric energy of $5,000 \mathrm{~J}$ and a $2.5 \mathrm{~V} \Delta \mathrm{p}$ energy of about $2,500 \mathrm{~J}$ did ignite the 23 -gal/ton shale. Such difficulty in igniting predispersed oil shale dust clouds of low assay was also observed by Richmond (4-5) in full-scale mine tests.

\section{EXPLOSIBILITY DATA}

The dust explosion data from the 20-L chamber for the fine oil shale and the comparison dusts ?e shown in figure 1-5 as a function of dust concentration. The pressure rise rate is shown in figure $1-5 A$, and the maximum explosion pressure ratio is shown in figure $1-5 B$. The explosion pressure ratio is the maximum explosion pressure (corrected for the small pressure rise due to the ignitor itself) divided by the pressure at ignition, which is about $1 \mathrm{~atm}$ absolute. The criteria (30) used to define the lean flammability limit (also known as the minimum explosible concentration) are a pressure ratio of 2 and a pressure rise rate of $5.4 \mathrm{~atm} / \mathrm{s}$. A pressure ratio of 2 corresponds to a pressure rise of approximately $1 \mathrm{~atm}$ above the pressure at ignition. The pressure rise rate, $\mathrm{dp} / \mathrm{dt}$, is often size normalized by multiplying by the cube root of the vessel volume. For the $20-\mathrm{L}\left(0.02-\mathrm{m}^{3}\right)$ chamber, the second flammability criterion would therefore correspond to a $(\mathrm{dp} / \mathrm{dt}) \cdot \mathrm{V}^{1 / 3}$ value of $1.5 \mathrm{bar} \cdot \mathrm{m} / \mathrm{s}(30)$. These flammability criteria assure that there is significant flame propagation beyond the ignition source.

The data shown in figure $1-5 B$ are for the strongest chemical ignitor, with $5,000 \mathrm{~J}$ calorimetric energy. For the dusts shown in the figure, Pittsburgh bituminous coal dust has the lowest lean limit and highest maximum explosion pressure. Gilsonite, which is not shown in the figure, has a lower lean limit and about the same maximum pressure as the Pittsburgh coal, as shown in table $1-3$. The $50-\mathrm{gal} /$ ton oil shale has a higher lean limit concentration and significantly lower maximum pressure than the Pittsburgh coal. The lower assay oil shales have progressively higher lean limits and lower maximum pressures.

The variation in the measured lean limits with ignition energy, shown in table 1-3, indicates the ease or difficulty in igniting the various dusts. Pittsburgh coal can be ignited at almost as low a concentration with the $2,500-\mathrm{J}$ ignitor as with the 5,000-J ignitor. The more difficult to ignite 50-gal/ton shale can be ignited at much lower concentrations with the stronger ignitor. The same is true for the $33-\mathrm{gal} / \mathrm{ton}$ shale. The $23-\mathrm{gal} / \mathrm{t}$ on shale and the sulfide ore could not be ignited with the 2,500-J ignitors. As discussed in previous publications (14, 18. 30). the true lean limit concentration for dust explosibility 

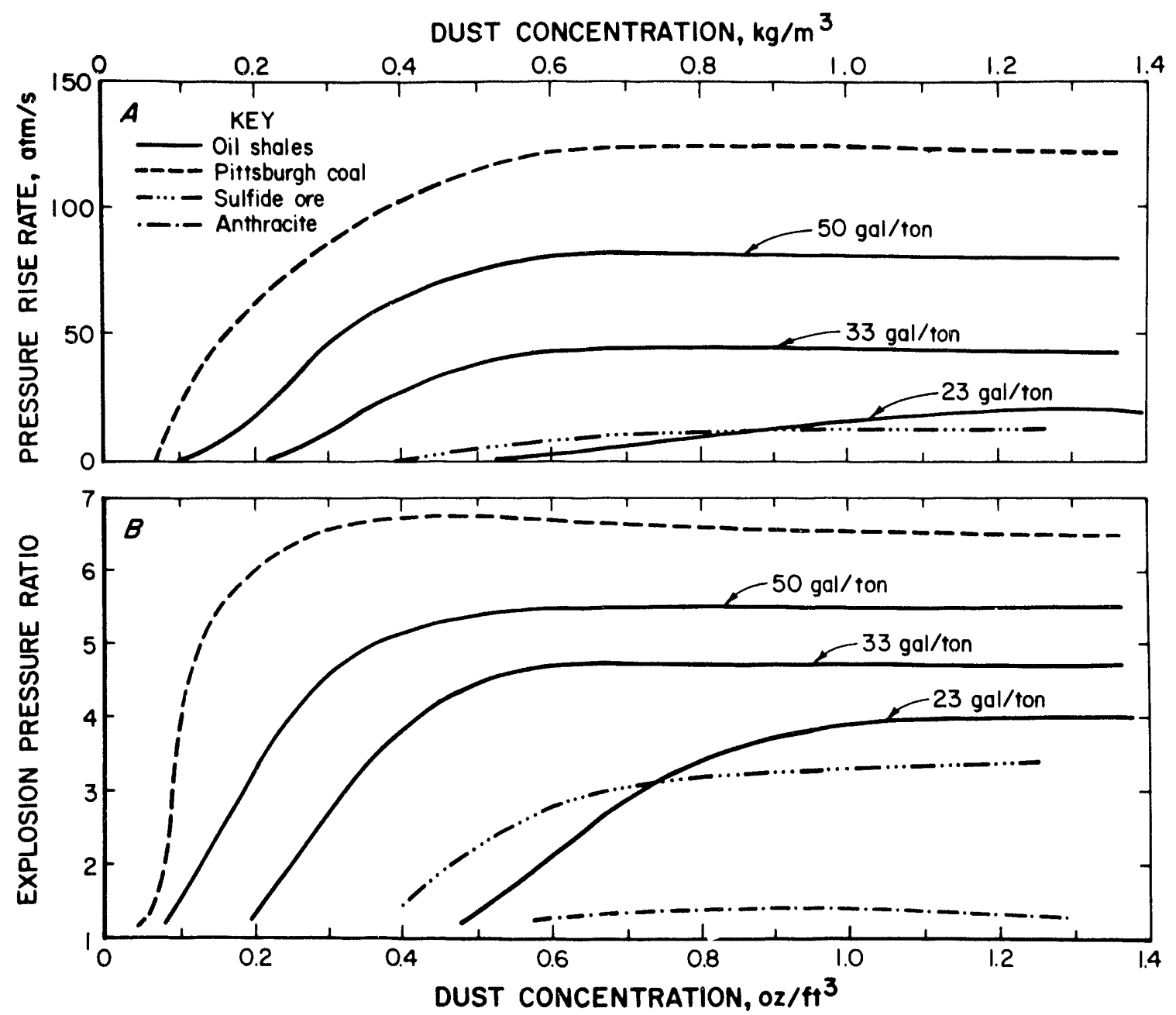

Figure 1-5. - Explosibility data for fine oil shales compared with Pittsburgh coal, sulfide ore, and anthracite coal of similar size.

Table 1-3.-Explosibility data for the oil shale and comparison dusts

\begin{tabular}{|c|c|c|c|c|}
\hline \multirow[t]{2}{*}{$\begin{array}{l}\text { Dust } \\
\text { sample }\end{array}$} & \multicolumn{2}{|c|}{$\begin{array}{l}\text { Lean flammability } \\
\text { limit, } \mathrm{kg} / \mathrm{m}^{3} \text {, with } \\
\text { ignitor of- }\end{array}$} & \multirow{2}{*}{$\begin{array}{l}\text { Maximum } \\
\text { pressure } \\
\text { rise, atm }\end{array}$} & \multirow{2}{*}{$\begin{array}{c}\text { Maximum rate } \\
\text { of pressure } \\
\text { rise, atm/s }\end{array}$} \\
\hline & $2,500 \mathrm{~J}$ & $5,000 \mathrm{~J}$ & & \\
\hline \multicolumn{5}{|c|}{ FINE-SIZE DUST } \\
\hline 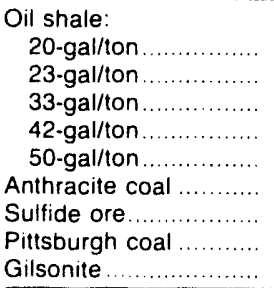 & $\begin{array}{c}- \\
\mathrm{NI} \\
0.42 \\
.20 \\
.20 \\
- \\
\mathrm{NI} \\
.090 \\
.040\end{array}$ & $\begin{array}{c}-0.8 \\
.6 \\
.25 \\
.16 \\
.13 \\
\mathrm{NI} \\
-.5 \\
.080 \\
.037\end{array}$ & $\begin{array}{r}2.7 \\
3.0 \\
3.7 \\
4.5 \\
4.5 \\
.4 \\
-2.3 \\
5.6 \\
6.0\end{array}$ & $\begin{array}{r}11 \\
21 \\
44 \\
85 \\
85 \\
<1 \\
-10 \\
130 \\
280\end{array}$ \\
\hline \multicolumn{5}{|c|}{ COARSE-SIZE DUST } \\
\hline $\begin{array}{l}\text { Oil shale: } 33 \text {-gal/ton ... } \\
\text { Pittsburgh coal ........... }\end{array}$ & $\begin{array}{l}\mathrm{NI} \\
0.27\end{array}$ & $\begin{array}{r}-0.7 \\
.15\end{array}$ & $\begin{array}{l}3.3 \\
5.1\end{array}$ & $\begin{array}{l}-20 \\
-80\end{array}$ \\
\hline
\end{tabular}

NI Nonignitable

NOTE.-Dashes indicate no data were obtained. is the value measured with a high enough ignition energy so that the limit is independent of ignition energy. The data in table 3 show that this true limit is probably reached for the coal, but that even with the 5,000-J ignitors, the measured limits for the oil shales may not yet be independent of ignition energy.

The 20-gal/ton fine oil shale produced explosions only at very high concentrations $\left(0.8\right.$ to $\left.1.5 \mathrm{~kg} / \mathrm{m}^{3}\right)$ in the $20-\mathrm{L}$ chamber. These results are comparable to results from the full-scale mine tests $(3,5)$ that found that 22 -gal/ton fine oil shale dust could produce explosions at high concentrations, but that 19-gal/ton shale did not propagate explosions.

The sulfide ore that was tested is somewhat comparable in explosion hazard to the lower grade oil shales. It should be noted that there is a wide range of sulfide ores (of varying sulfur content) and that some sulfide ores have been involved in secondary explosions during blasting in mines $(23-24)$. For the anthracite coal, the slight pressure rise observed was only due to a small amount of burning around the ignition source and does not signify flame propagation. Therefore, this 5 pct-volatile anthracite is considered nonexplosible in air in the 20-L tests. Full-scale mine tests (24) have also shown that anthracites do not propagate explosions. 
The data in figure $1-5.4$ for maximum rates of pressure rise are similar to the pressure data exeept that the differences among the various dusts are more pronounced. These data are also listed in the last column of table $1-3$. The rate's of pressure rise are very dependent on the turbulence in the chamber, and therefore, the data should be used only for a relative comparison among the various dusts. A higher level of turbulence would increase the rates of pressure rise for all the dusts.

The 20-L explosibility data for the coarse oil shale dust (33 gal/ton) are compared with those for the fine shale of the same assay in figure 1-6. The maximum pressures for both sizes were similar, but a much higher concentration of the coarse dust was required to reach he maximum pressure. The lean limit for the coarse dust using the $5,000-$-J ignitors was about three times the limit for the fine dust using the same ignitor. The coarse dust could not be ignited with the $2,3(0)-1$ ignitors, but the fine dust could be ignited even with $1,0(0)(1-.1$ ignitors.

The coarse-size Pittsburgh coal was tested for comparison. Its lean limit was about two times the limit for the fine-size coal using the same ignitor. For both the coal and 33-gal/ton oil shate, the coarse dusts had much higher lean limits than the fine dusts. A summary of the explosibility data for the coarse dusts in the 2()-L chamber is listed at the bottom of table $1-3$. The maximum pressures and rates of pressure rise for the coarse dusts are lower than those for the fine dusts of the same type.

In previous tests in the experimental mine $(3,5)$, this same 33-gal/ton coarse oil shate dust did propagate an explosion at a high nominal concentration of about $0.5 \mathrm{~kg} / \mathrm{m}^{3}$

\section{PARTICLE SIZE VARIABLE AND MICROSCOPIC OBSERVATIONS}

In a previous study (3/) of coal dust and polyethylene powder, it was possible to isolate the particle size variable and to measure the effect of particle diameter on the lean limit of flammability and the minimum AIT. Using narrow size distributions for coal and polyethylene with average diameters ranging from 210 over $4(0) \mu \mathrm{m}$, it was determined that the lean limits were insensitive to particle size below some characteristic diameter. Above these characteristic diameters of $50 \mu \mathrm{m}$ for Pittshurgh Seam coal dust and $100 \mu \mathrm{m}$ for polyethylene, the lean limit concentrations increased markedly with increasing particle diameter. The minimum AIT's for coal dust and

"ethylene powder displayed a similar particle size depend- cee except that at the elevated temperatures involved, both the characteristic diameters were larger. It was, therefore, quite logical to attempt to initiate a similar study of the effect of particle size on the flammability limit and thermal ignitability for the oil shale dust studied here. In the case of polyethylene. which is a totally volatilizable, homogeneous solid, the particle size and volatility variables are readily separable. Even though the coal structure is heterogeneous and contains separate pyritic inclusions, the data in figures $1-7.4$ and $B$ show that there is no tendency for these separate phases to concentratc in

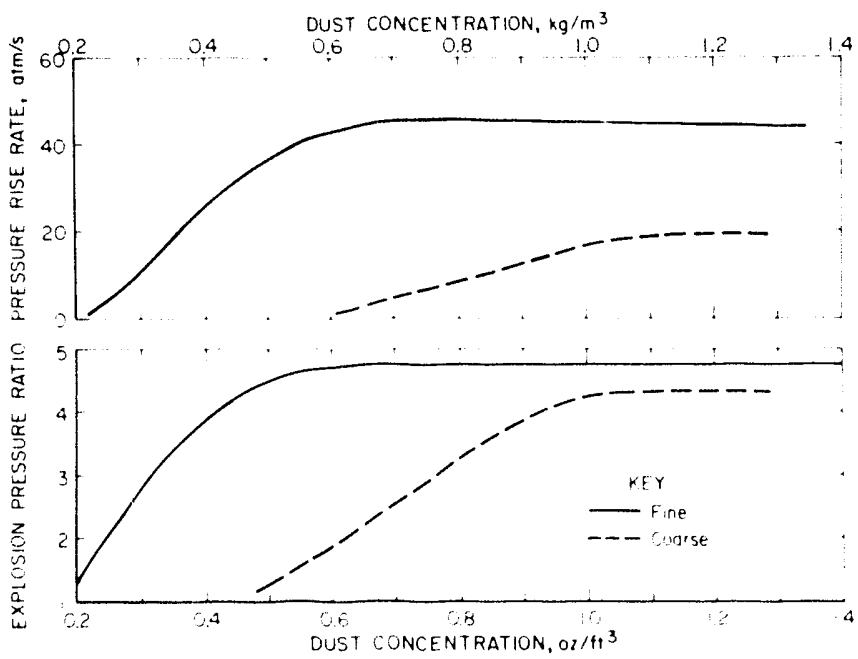

Figure 1-6. -Expiosibility data for coarse and fine sizes of 33-gal/ton oil shale. either the fine or the coarse fractions of the sieved dust. The volatile content and heating value are essentially independent of particle size, despite the heterogeneous structure of the coal.

Figure $1-7 C$ shows a different behavior for a broad sice distribution of 33-gat/ton oil shale that was sieved to obtain the various sizes shown. There is an increase in the heating value with increasing particle size until the heating value levels off at the $300-101,000-\mu \mathrm{m}$ particle size range. The heating values are proportional to the Fischer assays as shown in a previous Bureau publication (5). This observation of lower heating values or fower assays associated with the finer sizes of oil shale has been reported previously $(2,10)$. This variation in assay with particle size is a reflection of the basic heterogeneous structure of the oil shate and the way in which that

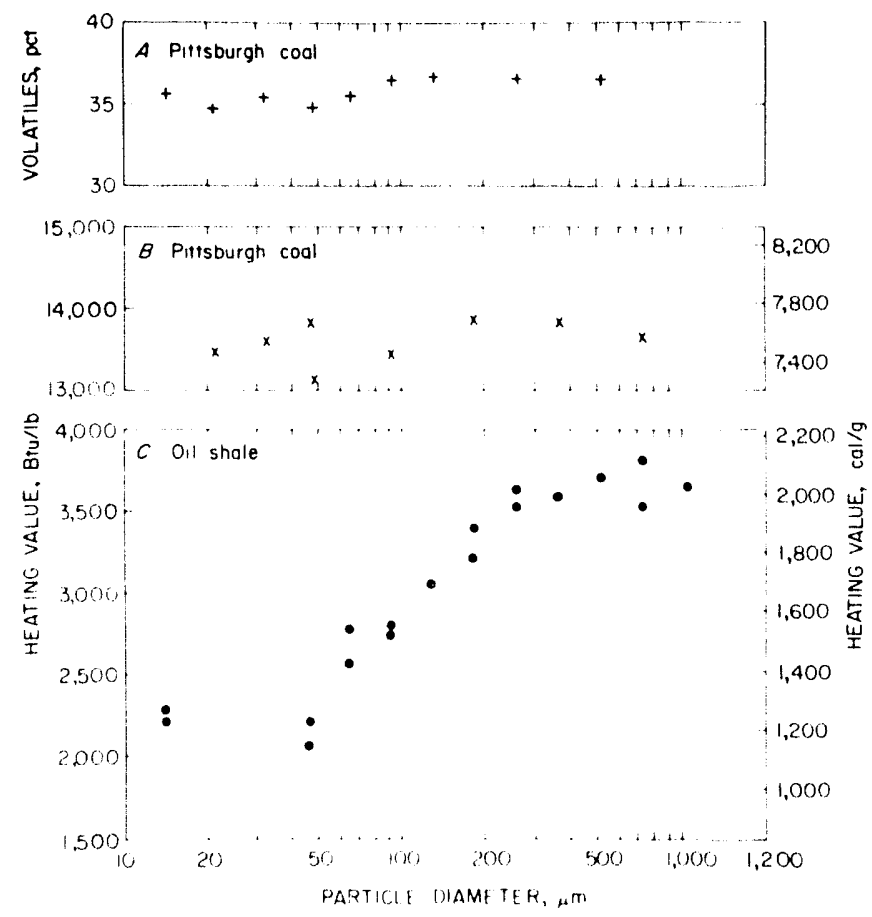

Figure 1-7.- Heating value for oil shale as function of particle size compared with heating value and volatile content of Pittsburgh coal. 
heterogeneity affects its pulverization. This variation is consistent with the structure studies of Tisot and Murphy (32), who showed that the average particle size of the mineral matter in the Green River shale deposit was less than $44 \mu \mathrm{m}$. The parent oil shale rock is a heterogeneous agglomerate consisting of fine mineral particles bound together by a soft kerogen glue or matrix in some regions and by an inorganic cementing agent in other regions. When the shale is pulverized, the fine mineral particles are more easily separated from the matrix, leaving a higher kerogen concentration in the larger particles. This structural heterogeneity and grinding behavior of the oil shate also serves as a basis for the physical concentration method for oil shale enrichment described by Fahlstrom (33). Independent studies of comparable methods were later reported by others (34-36) at the 16th Oil Shale Symposium in 1983.
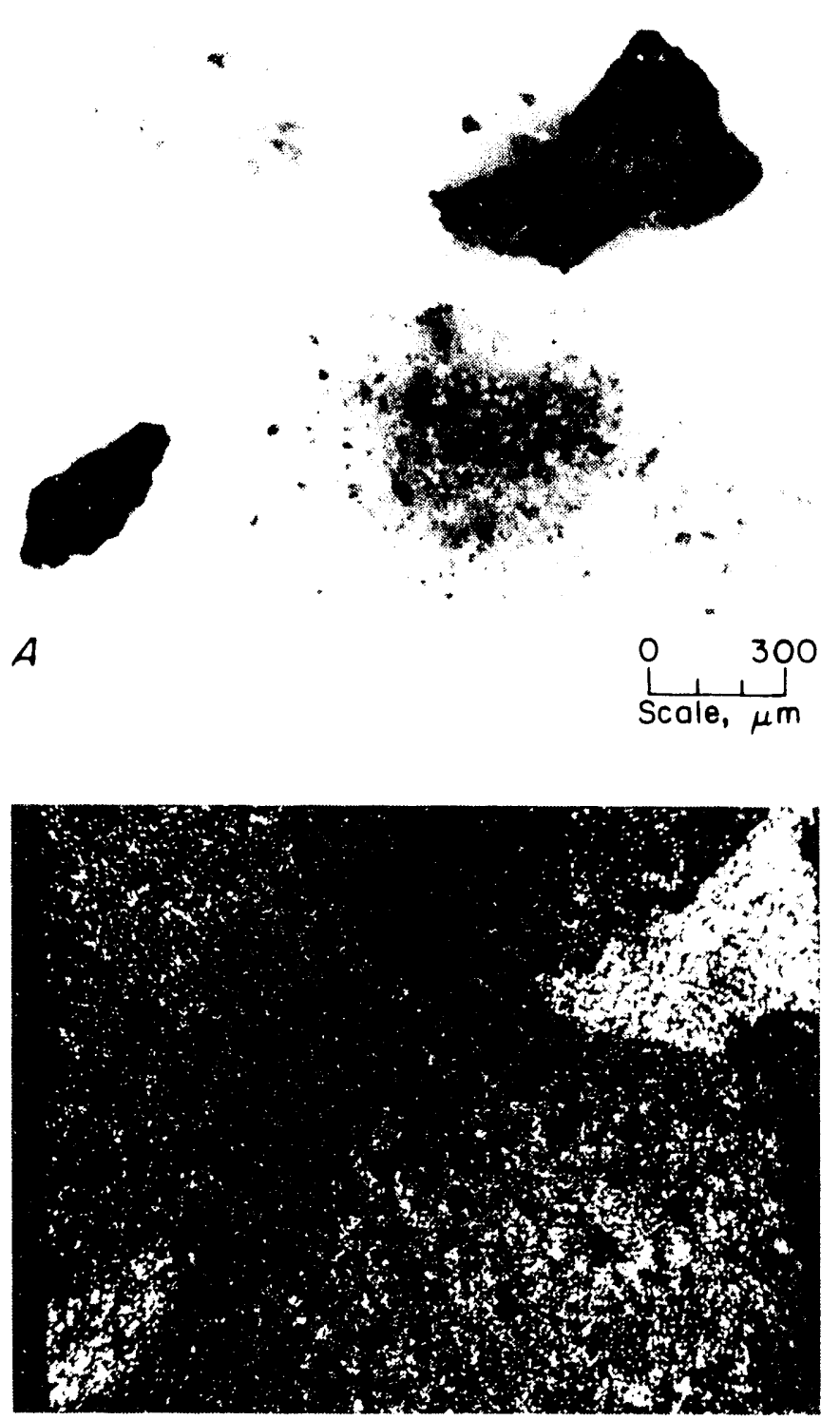

C Si $X$-ray map

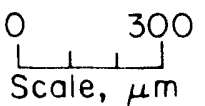

This structural heterogeneity is clearly illustrated by the optical and scanning electron microscope (SEM) data shown in figure 1-8. A second sample of various sieved fractions was sampled and analyzed with an optical mieroseope and with the $\mathrm{X}$-ray imaging feature $(37)$ of the SEM. Figure $1-8 A$ shows an optical photomicrograph of a collection of particles from several of the various sieved fractions. In the upper left portion of figure $1-8 . \mathrm{A}$ is an approximately $600-\mu \mathrm{m}$-diam particle from the 40- by 30 -mesh sieved fraction. This particle was selected because of its high optical transparency. The three corresponding SEM X-ray maps were made by collecting only the X-rays from a particular element to form an image showing the distribution of that element over the field of view (37). A comparison of the three X-ray images show that the $600-\mu \mathrm{m}$ transparent particle contains a large amount of calcium and
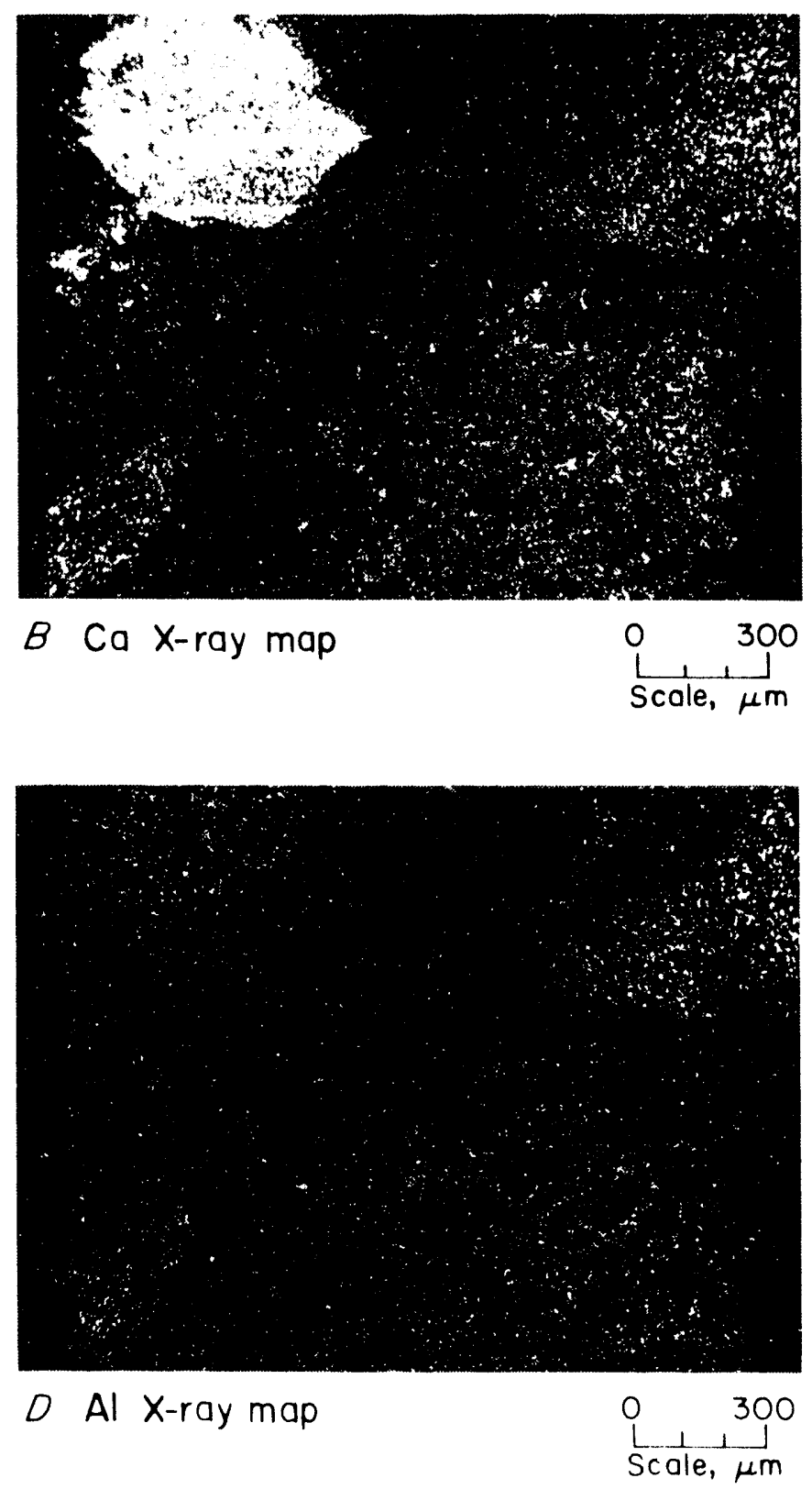

Figure 1-8. -Optical microscope photograph of oil shale particles $(A)$ and corresponding SEM X-ray maps for elements calcium $(B)$, silicon $(C)$, and aluminum $(D)$. 
only trace amounts of silicon and alumimum. Therefore, that particle is most likely calcitic in composition.

In the upper right quadrant of ligure $1-8.4$ is a particle from the 40- by $3(0$-mesh sieved fraction that was selected because it was one of the more opaque particles observed with the optical microscope. This particle is clearly much more heterogeneous in structure than the calcitic particle. Some areas of the particle appear quite dark and are probably high in kerogen content; lighter areas are probably mineral matter. The corresponding $X$-ray maps in figures $1-8 B, C$, and $D$ show a strong silicon $X$-ray signal and weaker signals from both the calcium and aluminum for this particle. Thus, its heterogeneous structure seems to contain the organic kerogen matrix together with mineral matter such as quart/, feldspar, spurrite, calcite, dolomite, etc. (38).

The dark particle in the lower left quadrant of figure 1-8.4 was selected from the 10)- by 7()-mesh fraction. This particle is even darker than the previous particle, and its corresponding X-ray maps show some silicon and smaller amounts of aluminum and calcium. This particle anpears to be another highly heterogeneous agglomerale but w th a higher kerogen content than the particle in the upper right quadrant.

The lower right quadrant contains a large number of very small particles from the minus $4(0)$-mesh sieved fraction. Probably each of these small, individual mineral particles is fairly homogeneous in structure (32), and the data in figure $1-7 C^{\prime}$ show that these smaller particles atre lower in organic content.

These structure stuties show that the particle size and oil content variables are not independent. The fact that the heating value (or kerogen content) decreases with decreating particle size may have a moderating effect on the potential explosion hazard of dust generated in a practical mining situation. The fundamental heterogeneous structure of the oil shale deposits also has implications for the effective design of retorting or pyrolysis systems for the efficient recovery of the shate's oil content $(3 l)$.

\section{DISCUSSION AND CONCLUSION}

The fundamental conclusion of part 1 is that fine oil shale dusts with Fischer assays of 20 gal/ton or greater are a potential explosion hazard and that even relatively coarse sizes of such dusts can propagate an explosion if the dust concentration is high enough. However, measurements $(9,1 /)$ have shown that, with current mining practices, the accumulated dust levels in oil shale mines are well below that required to propagate an explosion if the dust were dispersed. Recent measurements (39-40) have shown that during blasting operations there may be pockets of higher dust concentration near the face that could result in some localized burning of oil shale dust. However, there is not enough dust generated during blasting to cause large-scale propagating explosions. If methane were present in the mine in addition to the oil shale dust, the potential hazard would be increased.

In surface facilities that process, grind, or beneficiate oil shale, the concentrations may exceed the minimum explosible concent rations (lean limits) listed in table $1-3$. Therefore, these facilities should he evaluated for potential explosion hazard on a case-by-case basis.

The flammability and ignitability data reported in this part have broadened the comparison of various-grade oil shales to include other dusts with more extensive mining histories. Fine 50-gal/ton oil shale dust is only slightly less hazardous than a similar size of Pittsburgh coal in terms of its lean flammability limit concentration and the explosion pressures generated, but it is at least an order of magnitude more difficult to ignite with an electric spark. For the fine shates, the lowest assay that could propagate an explosion was 20 gal/ton. Sulfide ore, which has a history of secondary dust explosions during blasting in mines, is comparable in explosion hazard to the lower grade oil shales. All of the oil shales tested were somewhat more easily ignited thermally than was the Pittsourgh coal since the AlT's of oil shale dust clouds were lower than that of the coal.

For the safety engineering design of pressure-release (venting) systems to protect equipment and personnel against excessive pressures during dust explosions, the (West) (jerman Society of Engineers (Verein Deutscher Ingenieure or VDI) and the National Fire Protection Association (NFPA) have published detailed guidelines $(4 /-42)$. The VDI classification is based on an index that is the maximum rate of pressure rise, normalized to a $1-m^{\prime}$ lest chamber. This index is $k$, $(\mathrm{dp} / \mathrm{dt})_{\text {max }} \cdot V^{\prime}{ }^{3}$ in bar meters per second, where $\mathrm{dp} / \mathrm{dt}$ is the rate of pressure rise and $V$ is the test chamber volume. If the exact $K_{4,}$-value is known for a dust, the nomograms can be used to determine venting areas. I:ven if only the general $\mathrm{K}_{\mathrm{S}_{1}}$-class is known, the nomograms can be used to determine approximate venting areas. The $\mathrm{K}_{S_{1}}$-classes are $\mathrm{St} 1$ for $(0) 200$ bar.m/s, St 2 for 200 to 300 bar.m $/ \mathrm{s}$, and St 3 for $>3(0) \cdot$ bar $\mathrm{m} / \mathrm{s}$. The VDI recommended test for rate of pressure rise is made at a higher turbulence level than the data reported here in table 1-3. However, even with this difference, the oil shales (with assays greater than 20 gal/ton) and the Pittsburgh coal can be confidently estimated to be in class Si 1 according to the VDI guideline. The gilsonite would probably be near the boundary between classes St 1 and St 2 if tested at the higher turbulence level.

The NFPA has developed the National Electrical code (NEC) for electrical equipment in hazardous locations (43-46). Dusts are classified according to their explosion severity and ignition sensitivity indexes based on old Bureau of Mines testing procedures in the 1.2-L. Hartmann chamber and 0.3-L. Godbert-Cireenwald furnace (13). These indexes can also be calculated from the data (tables $1-2$ and $1-3$ ) obtained in the newer 20-1. chamber and 1.2-1. furnace. According to the data, the fine-size 50-gal/ton oil shale would have an explosion severity of about 0.5 relative to a Pittsburgh coal value of 1.0 and an ignition sensitivity less than 0.05 relative 10 a Pittsburgh coal value of 1.0. The NFPA-NI: ( classification system says that the presence of dust with explosion severity greater than 0.5 and ignition sensitivity greater than 0.2 makes an area a Class Il location (one made hazardous by combustible dust). Dusts with lower explosibility indexes are not considered to be significant explosion hazards in terms of electrical equipment. Therefore, the 5()-gal/ton oil shale dust would be only a weak explosion hazard and the lower assaly shales even less of a hazard in terms of electrical equipment. According to the NFPA classification scheme, the oil shales listed in tables 1-2 and $1-3$ do not require electrical equipment suitable for ('ass II hazardous locations. Hoxicere, the resules of the 2()-1 laboratory tests and the results from the experimental mine tests (3-5) have shown that stronger ignition sources, similar to those that might be present during blasting operations, can ignite oil shale dust clouds (with assays greater than 20) gal/ton) and lead on propagating dust explosions if the dust concentration is sufficient. 


\section{REFERENCES}

1. Allison, V. C., and A. D. Batuer. Explosibility of Oil-Shale Dust. BuMines RI 2758, 1926, $8 \mathrm{pm}$.

2. Richmond, J. K., and L. I: Miller. Explosion and Fire Properties of Oil Shale. Paper in 10th Oil Shale Symposium Proceedings (Ciolden, (C), Apr. 21-22, 1977). (O) Sch. Mines Press, Ciolden, (O) 1977, pp. $45-59$

3. Richmond, J. K., M. J. Sapko, L. F. Miller, A. L. I urno, and I. E. Dalverny. Fire and Explosion Properties of Oil Shale, Part II. Paper in 13th Oil Shate Symposium Proceedings (Golden, CO, Apr. 16-18, 1980). CO Sih. Mines Press, Ciolden, CO, 1980, pp. 193-207.

4. Richmond, J. K., M. J. Sapko, L. F. Miller, and L. E. Dalverny. Explosion Hazards in Gassy and Non-Gassy Oil Shale Mines. Paper in 14th Oil Shale Symposium Proceedings (Golden, CO, Apr. 22-24, 1981). CO Sch. Mines Press, Golden, (O), 1981, pp. 61-74.

5. Richmond, J. K., M. J. Sapko, and L. F. Miller. Fire and Explosion Properties of Oil Shale. BuMines R1 8726, 1982, $39 \mathrm{pp}$.

6. Sapko, M. J., J. K. Richmond, and J. P. McDonnell. Continuous Monitoring of Methane in a Deep Oil Shale Mine. Paper in 15 th Oil Shale Symposium Proceedings (Ciolden, CO, Apr. 28-30, 1982). CO Sich. Mines Press, Golden, CO, 1982, pp. 320-340.

7. Crookston, R. B., M. T. Atwood, R. E. Williams, and M. D. Meciuire. An Evaluation of the Fire and Explosion Harards of Oil Shale Mining and Processing. Volume 1: Analytical Studies and Accident Scenarios (contract J0275001, Toseo (orp.). BuMines OFR 12(1)-85, 1983, 268 pp.; NTIS PB 85-165492.

8. Crookston, R. B., and M. D. Mc (iuire. An Evaluation of the Fire and Explosion Hazards of Oil Shale Mining and Processing. Volume 2: Data Summary of Anvil Points Raw Shale Waste Pile Combustion (contract 102750)1, Tosco Corp.). BuMlines OFR 12(2)-85, 1983, 144 pp.; NTIS PB 85-165959.

9. An Evaluation of the Fire and Explosion Hazards of (Oil Shale Mining and Processing. Volume 3: Oil Shale Mine Dust Program (contract J0275001, Tosco Corp.). BuMines OFR 12(3)-85, 1983, 74 pp., NTIS PB 85-165967.

10. Alwood, M. T., L. (ioodfellow, and R. K. Kauffman. Chemical and Physical Properties of Oil Shale Dust and Correlations With Laboratory Fire and Explosivity Test Results. Paper in 12th Oil Shale Symposium Proceedings (Golden, (CO, Apr. 18-20), 1979). (O Sch. Mines Press, Golden, (C), 1979, pp. 299-315.

11. Crookston, R. B., and W. N. Hoskins. Potential for Fires and Esplosions in Oil Shale Mining and Processing. Paper in 12th Oil Shalc Symposium Proceedings (Golden, CO, Apr. 18-20, 1979). (O) Sch. Mines Press, (iolden, CO, 1979, pp. 326-338.

12. Williams, R. E., Z. Zborovs/ky, R. M. Blunt, and D. West. Laboratory and Fire Explosivity Testing of Oil Shale Dust. Paper in 12th Oil Shale Symposium Proceedings (Golden, (O, Apr. 18-20, 1979). (C) Sch. Mines Press, Golden, (O, 1979, pp. 316-325.

13. Dorsett, H. G., Jr., M. Jacobson, J. Nagy, and R. P. Williams Laboratory Equipment and Test Procedures for Evaluating Explosibility of Dusts. BuMines RI 5624, 1960, $21 \mathrm{pp}$.

14. Herteberg, M., K. I. Cashdollar, and J. J. Opterman. The Flammability of Coal Dust-Air Mixtures. Lean Limits, Flame Temperatures, Ignition Energies, and Parricle Size Effects. BuMines RI $8360,1979,70 \mathrm{pp}$.

15. Cashdollar, K. I., and M. Hertzberg. 20-1. Explosibility Test Chamber for Dusts and (iases. Kev. Sci. Instrum., s. 56, 1985, pp. 596-602.

16. Cashdollar, K. L., M. Hert/berg, and R. S. Conti. Explosion Hazards of Oil Shale Dusts: Limits, Pressures, and Ignitability. Paper in 17th Oil Shale Symposium Proceedings (Ciolden, (C), Apr. 16-18, 1984). (C) Sch. Mines Press, Golden, (O), 1984, pp. 243-254

17. (ashdollar, K. 1.., M. Hertaberg, and J. K. Richmond. Inhibi tion of Coal Dust Explosions: Comparison of the 8-1 iter Laboratory Chamber and Experimental Mine. Paper 1.4 in 20th International Conference of Safety in Mines Research Institutes, Sheffield, England, October 3-7, 1983. HSE, 1983,11 pp.

18. Hertzberg, M., K. I. (ashdollatr, and (.. P. Iazzara. The limit of Flammability of Pulverized coals and Other Dusts. Paper in tighteenth Symposium (International) on combustion (Waterloo, Canada, Aug. 17-22, 19801). Combustion Inst., Piltsburgh, PA, 1981, pp. 717-729.
19. Cashdollar, K. L., M. J. Sapko, E. S. Weiss, and M. Herlaberg. laboratory and Mine Dust Explosion Research at the Bureau of Mines. Paper in Industrial Dust Lxplosions. ASTM, Philadelphia, PA, STP 958, 1987, pp. 107-123.

20. Stanfield, K. E., and I. C. Frost. Method of Assaying (Oil Shale by a Modified Fischer Retort. BuMines RI 4477, 1949, $13 \mathrm{pp}$.

21. American Society for Testing and Materials. Standard Test Method for Ciross Calorific Value of Solid liuel by the Adiabatic Bomb Calorimeter, D2015; Standard Test Method for Proximate Analysis of Coal and Coke, D3172. Sections in 1987 Annual Book of ASTM Standards: Volume 05.05, Gaseous Fuels; Coal and Coke. Philadel. phia, PA, 1987, pp. 304-314, 380-381.

22. Hartmann, I. Studies on the Development and Control of Coal-Dust Explosions in Mines. BuMines IC 7785, 1957, $27 \mathrm{pp}$.

23. Ciardner, E. D., and E. Stein. Explosibility of Sulphide Dusts in Metal Mines. BuMines RI 2863, 1928, $11 \mathrm{pp}$.

24. Nagy, J. The Explosion Hazard in Mining. MSHA, IR I119, $1981,69 \mathrm{pp}$.

25. Cashdollar, K. L., I. Liebman, and R. S. Conti. Three Bureau of Mines Optical Dust Probes. BuMines RI 8542, 1981, 26 pp.

26. Conti, R. S., K. L. Cashdollar, and I. Liebman. Improved Optical Probe for Monitoring Dust Explosions. Kev. Sci. Instrum., v. 53. 1982, pp. 311-313.

27. Conti, R. S., K. L. Cashdollar, M. Hertzberg, and I. Liebman. Thermal and Electrical Ignitability of Dust Ciouds. BuMines RI 8798, $1983,40 \mathrm{pp}$.

28. Hertzberg, M., R. S. Conti, and K. I. Cashdollar. Spark Ignition Energies for Dust-Air Mixtures: Temperature and Concentration Dependences. Paper in Twentieth Symposium (International) on Combustion (Ann Arbor, MI, Aug. 13-17, 1984). Combustion Inst., Pittsburgh, PA, 1985, pp. 1681-1690.

29. Hertzberg, M., R. S. Conti, and K. L., Cashdollar. Electrical Ignition Energies and Thermal Autoignition Temperatures for Evaluating Explosion Hazards of Dusts. BuMines RI 8988, 1985, 41 pp.

30. Hertzberg, M., K. L. Cashdollar, and I. A. Zlochower. Flammability Limit Measurements for Dusts and Gases: Ignition Energy Requirements and Pressure Dependences. Paper in Twenty-First Symposium (International) on Combustion (Munich, Federal Republic of (iermany, Aug. 3-8, 1986). Combust. Inst., Pittsburgh, PA, 1988, pp. 303-313.

31. Hertzberg, M., K. L. Cashdollar, D. L. Ng, and R. S. Conti. Domains of Flammability and Thermal Ignitability for Pulverized Coals and Other Dusts: Particle Size Dependences and Microscopic Residue Analyses. Paper in Nineteenth Symposium (International) on Combustion (Haifa, Israel, Aug. 8-13, 1982). Combustion Inst., Pittsburgh, PA, 1982, pp. 1169-1180.

32. Tisot, P. R., and W. I. R. Murphy. Physical Structure of Green River Oil Shale. Chem. Eng. Prog., Symp. Ser., v. 61, 1965, pp. 25-32.

33. Fahlstrom, P. H. A Physical Concentration Route in Oil Shale Winning. Paper in 12th Oil Shale Symposium Proceedings (Golden, CO, Apr. 18-20, 1979). (O Sch. Mines Press, Ciolden, CO, 1971), pp. 252-277.

34. Datta, R. S., and C. A. Salotti. Coarse Beneficiation of (ireen River (Oil Shale. Paper in $16 \mathrm{th}$ (Oil Shale Symposium Proceedings (Golden, CO, Apr. 13-15, 1983). CO Sch. Mines Press, Ciolden, CO, 1983, pp. 413-425

35. Krishnan, (i. N., E. P. Farley, and R. (i. A urray. Beneficiation of U.S. Oil Shales by Froth Flotation. Paper in 16th Oil Shale Symposium Proceedings (Ciolden, CO, Apr. 13-15, 1983). (O) Sch. Mines, Golden, CO, 1983, pp. 426-436.

36. Salotti, C. A., and R. S. Datta. Size Reduction of (ireen River Shale. Paper in 16 th Oil Shale Symposium Proceedings (Ciolden, (C), Apr. 13-15, 1983). CO Sich. Mines Press Golden, (O), 1983, pp. 394-412.

37. Ng, D. I.., K. I.. Cashdollar, M. Hertzberg, and C. P. Lazara. Electron Microscopy Studies of Explosion and Fire Residues. BuMines IC $8936,1983,63 \mathrm{pp}$.

38. Branch, M. C. In-Situ Combustion Retorting of (Oil Shale. Prog. Energy and combust. Sici., v. 5, 1979, pp. 193-206. 
39. Weiss, E. S., K. L. Cashdollar, and M. J. Sapko. Dust and Pressures Generated During Commercial Oil Shale Mine Blasting. Paper in $18 \mathrm{ch}$ Oil Shale Symposium Proceedings (Grand Junction, CO, Apr. 22-24, 1985). (CO Sch. Mines Press, Golden, (CO, 1985, pp. $68-76$

40. Dust and Pressure (ienerated During Commercial Oil Shale Mining: Part II. Paper in 19th Oil Shale Symposium Proceedings (Ciolden, CO, Apr. 21-22, 1986). CO Sch. Mines Press, Ciolden, CO, 1986, pp. $47-58$

41. Verein Deutscher Ingenieure (German Society of Engineers). Druckentlastung von Staubexplosionen (Pressure Release of Dust Explosions). VDI (iuideline 3673 (in Cier., Engl., Fr.). VDI-Handbuch Reinhaltung der Luft, v. 6; available from Beuth Verlag, D-1000) West Berlin. Federal Republic of Germany, 1983, $51 \mathrm{pp}$.
42. National Fire Protection Association (Quincy, MA). Guide for Venting Deflagrations. NFPA 68, 1987, $51 \mathrm{pp}$.

43. National Electrical code 1987. Pp. 70-423 to 70-449.

44. Manual for Classification of (iases, Vapors, and Dusts for Electrical Equipment in Hazardous (Classified) Locations. NFPA 497M-1986, 1986, $27 \mathrm{pp}$

45. National Materials Advisory Board, Committee on Evaluation of Industrial Hazards. Classification of Combustible Dusts in Accordance with the National Electrical Code. Natl. Acad. Sci., Washington, DC, NMAB 353-3, 1980, $29 \mathrm{pp}$.

46. Classification of Dusts Relative to Electrical Equipmem in Class Il Hazardous Locations. Natl. Acad. Sci., Washington, DC, NMAB 353-4, 1982, $51 \mathrm{pp}$. 


\title{
PART 2: FIRE HAZARDS OF OIL SHALE DUST LAYERS ON HOT SURFACES
}

\author{
By Yael Miron' and Charles P. Lazzara²
}

\begin{abstract}
The U.S. Bureau of Mines determined the minimum hot-surface ignition temperatures of fine and coarse oil shale dusts ( 20 to $50 \mathrm{gal} /$ ton) from the Green River Formation in Colorado and fine and coarse Pittsburgh bituminous coal dust, using a hotplate. Dust layers were 10 $\mathrm{cm}$ in diameter and 6.4- to $25.4-\mathrm{mm}$ thick. Ignition criterion was a temperature rise within the dust layer of at least $50^{\circ} \mathrm{C}$ above that of the hotplate.

Minimum ignition temperatures for the fine dusts ranged from $200^{\circ}$ to $325^{\circ} \mathrm{C}$ and depended on layer thickness, and for the oil shales they were also a function of grade. The values for 50-gal/ton oil shale and Pittsburgh coal dusts were similar for layer thicknesses of 12.7 and $25.4 \mathrm{~mm}$. Coarse dust layers had significantly higher minimum ignition temperatures. Glowing particles were observed only in 50-gal/ton oil shale dust, most often with the 6.4-mm layers. Flaming combustion dici not occur in any of the tests. Layers of $50-\mathrm{gal} / \mathrm{ton}$ oil shale and Pittsburgh coal dust were also tested in an enclosure containing a flammable methane-air mixture at hotplate temperatures between $350^{\circ}$ and $400^{\circ} \mathrm{C}$. The layers underwent glowing combustion but did not ignite the flammable mixture.
\end{abstract}

'Chemical engineer

"Supervisory research chemist.

Pitlsburgh Research Center, U.S. Burcau of Mlines, Pitlsburgh, PA 


\section{INTRODUCTION}

The mining and processing of raw oil shale produce a combustible dust in underground mines and aboveground facilities. This dust settles on available surfaces in layer-like fashion. Some of these surfaces can be hot, such as the surfaces of engines and exhaust lines of diesel equipment and of electrical enclosures. If the temperatures of such surfaces are sufficiently high, various exothermic reactions, including combustion, can occur in the oil shale dust layers. The ignition of an oil shale layer in this manner could result in fire. Also, if a flammable gas atmosphere is present, as is possible in some deep oil shale mines ( $I),{ }^{\prime}$ an explosion might ensue. Largescale tests, at the Bureau's Experimental Mine, have demonstrated that oil shate dust can propagate an explosion when initiated by an ignited methane-air mixture (2). However, the likelihood for ignition of flammable methane-air mixtures by reacting layers of oil shale dust, heated by hot surfaces, has not been studied in detail.

In coal mines and in gassy noncoal mines, Federal regulations mandate the maximum permissible temperatures for various surfaces. As an example, in coal mines, the maximum temperature of the external surfaces of exhaust systems of diesel mine locomotives is limited to $204^{\circ} \mathrm{C}$ (3). Similarly, the temperature of any external surface of the engine or exhaust system of mobile diesel-powered transportation equipment for gassy noncoal mines is also limited to $204^{\circ} \mathrm{C}$ (4). This latter regulation is intended to prevent fires that might result from the contact of diesel fuel with the hot surface. For permissible electrical enclosures and mechanical components in coal mines, the surface temperature is not allowed to exceed $150^{\circ} \mathrm{C}$, under normal operating conditions (5). The National Electrical Code (NEC) also limits the maximum surface temperature of electrical equipment in locations that are hazardous because of the presence of combustible dust (6). The NEC states that the maximum temperature shall be less than the ignition temperature of the specific dust and in no case shall it be greater than $165^{\circ} \mathrm{C}$ for a nonconductive dust and electrical equipment not subject to overloading. For equipment such as motors and power transformers that may be overloaded, the maximum surface temperature is $120^{\circ} \mathrm{C}$ for normal operation and $165^{\circ} \mathrm{C}$ for abnormal operation.

In order to evaluate the hazards of oil stale dust layers on hot surfaces, the Bureau determined the minımum hot-surface ignition temperatures of a graded series of oil shale dusts and assessed the fire and explosion hazards associated with the combustion process.

Two tests have commonly been used to measure the minimum ignition temperature of a dust layer: a modified Godbert-Greenwald furnace test and a hotplate test. Most of the ignition temperature values for dust layers found in the literature were obtained in the modified Godbert-Greenwald furnace test (7). In this test (8), a relatively small sample of dust filling a $1 / 2$-in-deep, 1 -in-diam container made of $4(0$-mesh stainless steel is suspended in the center of the furnace, which is already heated to a set temperature considered likely to cause

\footnotetext{
Balic numbers in parentheses refer to them in the list of referencen all the end of part 2
}

ignition. A stream of air passes through an inlet orifice and flows upward through the furnace, at a rate that ranges between 0.5 and $3 \mathrm{~L} / \mathrm{min}$. The flow rate is adjusted so as to maintain the sample temperature at the furnace wall temperature if ignition does not occur. In successive trials, the temperature of the furnace is either increased or decreased by $5^{\circ} \mathrm{C}$ increments (as required) until a minimum is obtained at which ignition of dust just occurs. The ignition is denoted by an inflection in the temperature-time record of a thermocouple embedded in the dust as well as by visual observation of the top surface of the dust, via a mirror placed above the furnace. The duration of a test is regulated so that the dust maintains the set temperature of the furnace for a 5 -min period unless ignition occurs sooner. The duration of a test is usually on the o.der of $15 \mathrm{~min}$.

Various hotplate tests have also been used to determine the hot-surface ignition temperatures of dusts. Results of these tests are scattered in the literature and have not been compiled. A few tests have been made with oil shales. For instance, the Bureau conducted hotplate tests with oil shales from the Green River Formation, assaying at 19, 25, and $48 \mathrm{gal} /$ ton (9). In these tests, the dust was placed on a hotplate at room temperature, and the hotplate was then heated to a desired temperature. Both Godbert-Greenwald furnace tests and hotplate tests of oil shale dusts from the Green River Formation were conducted by the Tosco Corp. under Bureau contract (10), and results were reported for a limited number of tests.

The results obtained in previous hotplate tests suffer from the fact that neither the test equipment nor the testing procedure was standardized. In recognition of these drawbacks, the National Academy of Sciences Committee on Evaluation of Industrial Hazards, as part of a larger program to classify gases, vapors, and dusts in accordance with the NEC, recommended a detailed test procedure for the determination of the ignition temperature of dust layers $(I /)$. In this test, layers of dust are placed on the surface of a hotplate preheated to a desired temperature and the temperature within the layer is monitored. Both the thickness and the diameter of the layer can be varied, and in general, the samples are much larger than those used in the Ciodbert-Greenwald furnace test. Unlike the sample in the isothermal furnace, which is evenly heated, the sample in this test is heated on one side only; this condition more closely resembles actual conditions of deposited dust layers in the workplace.

Ignition, as defined by this hotplate test, is the initiation of combustion in the material under test. Ignition is considered to have taken place at the minimum hotplate temperature at which-

- There is visible evidence of combustion such as red glow or flame;

- The dust layer undergoes a $50^{\circ} \mathrm{C}$ rise in temperature atuve that of the hotplate as measured by a thermocouple in the geometric center of the layer; or

- The dust melts.

The test equipment and the procedures recommended by the committee were used in this study; the possibility that a burning dust layer could initiate the explosion of a flammable methane-air mixture was also examined. 


\section{EXPERIMENTAL EQUIPMENT AND PROCEDURES}

\section{HCTPLATE ASSEMBLY}

The test equipment consisted of a commercial hotplate, on which the centrally positioned circular aluminum plate was $20 \mathrm{~cm}$ in diameter and $2.5 \mathrm{~cm}$ thick. The temperature at the surface of the aluminum plate was controlled by a temperature controller connected to a thermocouple mounted just below the plate surface. The junction of the thermocouple was in contact with the plate and was within $1 \pm 0.5 \mathrm{~mm}$ of the upper surface, at its center.

The combination of heated plate and temperature controller met the following performance requirements, specified in the test procedure:

1. The plate is capable of attaining a temperature of 400$)^{\circ} \mathrm{C}$ without a dust layer in position.

2. The temperature of the plate is constant to within $\pm 5^{\circ} \mathrm{C}$ throughout the test.

3 . When the temperature of the plate reaches a constant value, the temperature across the plate is uniform to within $\pm 5^{\circ} \mathrm{C}$

4. The plate temperature does not change by more than $\pm 5^{\circ} \mathrm{C}$ during the placing of the dust layer on the plate, and it is restored to within $2^{\circ} \mathrm{C}$ of the set value within $5 \mathrm{~min}$ of placing of the sample.

5. Temperature controller and thermoco.sples are calibrated and correct to within $\pm 3^{\circ} \mathrm{C}$.

A stainless steel ring, placed on the aluminum plate, contained the dust layer and maintained its shape and size. The ring specified in the test procedure is $10 \mathrm{~cm}$ in diameter and $12.7 \mathrm{~mm}$ high, but rings of other dimensions were also used.
All the rings had slots at opposite ends of a diameter to accommodate the positioning of a thermocouple throght the sample and parallel to the surface of the aluminum plate. A fine ( -0.25 -mm-diam), bare type $k$ thermocouple was used, and its junction was positioned at the geometric center of the ring. This thermocouple measured the temperature inside the dust layer. A schematic of the hotplate is shown in figure 2-1. The whole assembly, consisting of the hotplate, temperature controller, and temperature indicators and/or recorders, was set up in a laboratory hood and is shown in figure 2-2.

KEY

Heated plate, $20-\mathrm{cm}$ diam Heating element

Connection to controller-power supply

D Ring for dust layer, $10-\mathrm{cm}$ diam

$E$ Plate thermocouple to controller

$F$ Dust layer thermocouple

$G$ Insulating cover

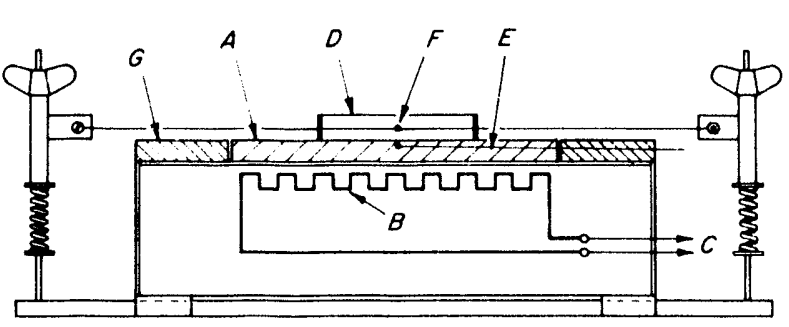

Figure 2-1.-Schematic of hotplate.

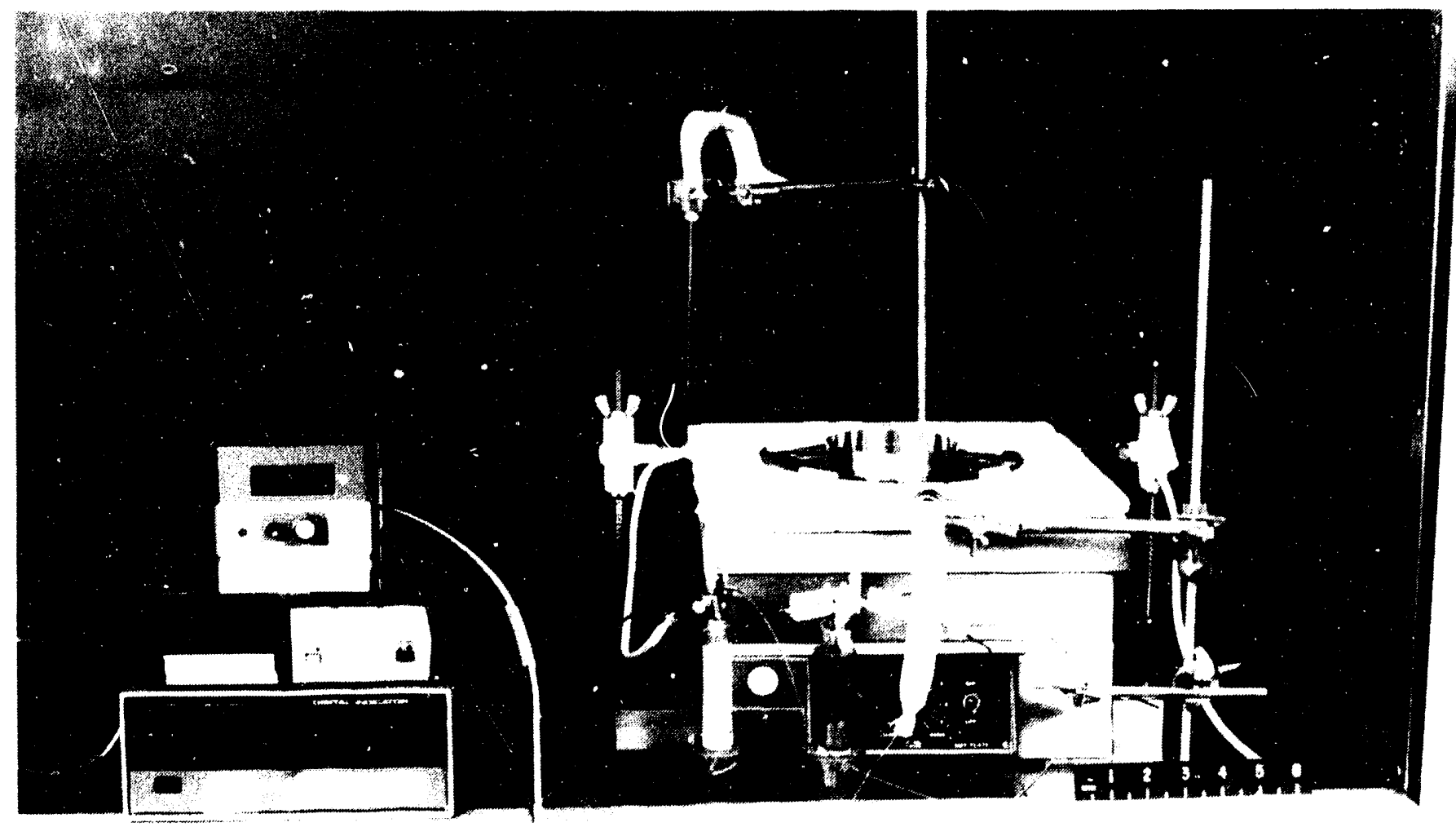

Figure 2-2.- Hotplate test apparatus in laboratory hood. 
Laver ignition tests were also conducted in a flammable atmosphere, with an enclosure placed over the hotplate to contain the gas mixture. This enclosure had an aluminum base and a plastic upper part that afforded a visual observation of the dust layers during the tests. Metered flows of air and methane were premixed prior to their entering the enclosure. Samples of the gas mistures were analyzed by gas chromatography to ensure the presence of the desired methane concentration. The complete assembly is shown in figure 2-3.

\section{TEST PROCEDURES}

\section{Minimum Hot-Surface Ignition Temperatures}

The sample thermocouple was first positioned so that its junction would be near the geometric center of the layer about to be tested. The stainless steel ring was then placed on the clean aluminum plate, and final adjustments were made in the themocouple position. A nreselected test temperature was set on the temperature controller, and the hotplate was heated. When the plate temperature stabilized at ihe set value, the stainless steel ring was filled with the test dust and the surface of the laver was leveled. Any excess powder, which spilled onto the aluminum plate, was removed. Efforts were made not to compress the dust layer. The temperatures of the hotplate and of the dust laver were monitored continuously to the end of the test. The duration of the tests varied with laver thickness, type and grade of dust, and with surface temperature, but in no

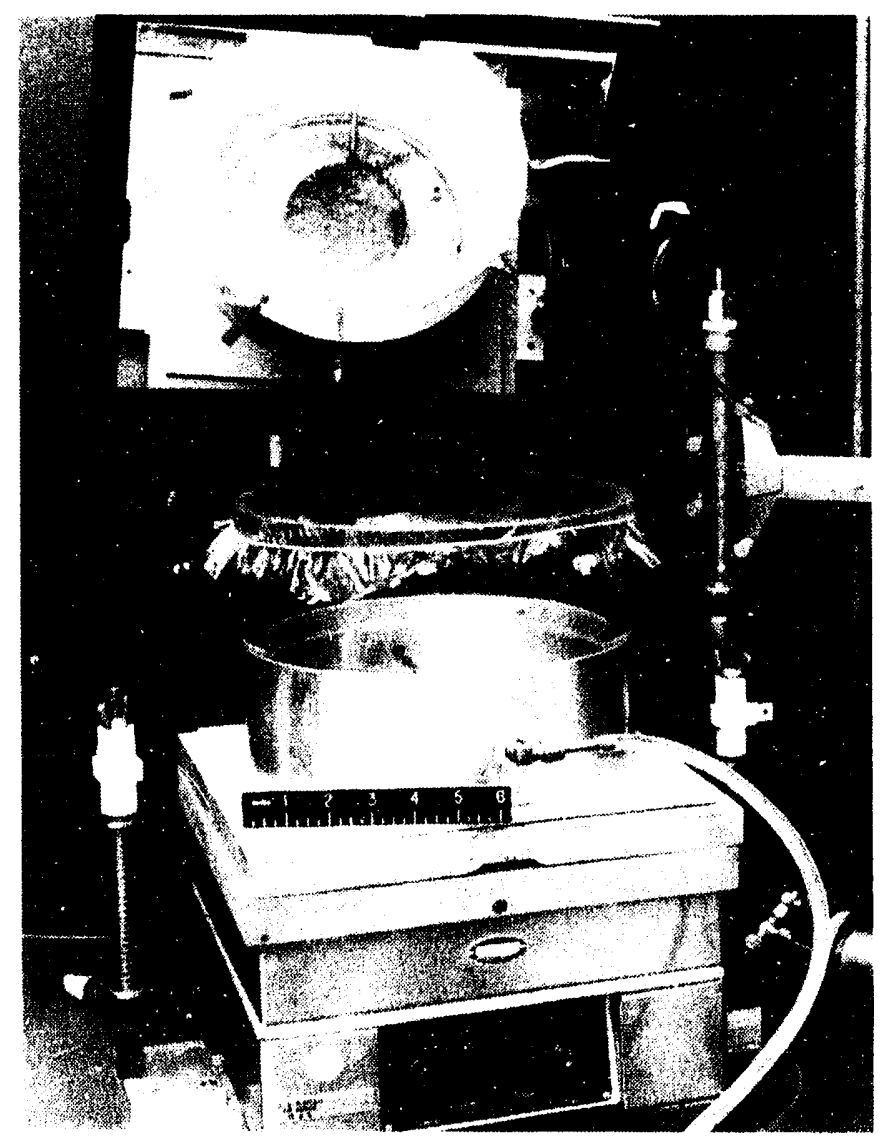

Figure 2-3.-Enclosure for flammable atmosphere in position on hotplate. catse was it less than 25 min for layers that ignited or less than $30 \mathrm{~min}$ for layers that did not ignite.

The temperature just under the surface of the dust layer was monitored with a 0.5 -mm-diam, stainless-steel-sheathed type $K$ thermocouple. Although not called for in the test procedure, it was helpful in indicating imminent reactions.

Trials were repeated with a fresh layer of dust each time, until the minimum ignition temperature was determined. The minimum ignition temperature is the temperature of the hotplate that just causes ignition in the dust laver; it is no more than $10^{\circ} \mathrm{C}$ higher than a hotplate temperature that fails to cause ignition. At least two or three tests were conducted at the hotplate temperature that just failed to cause ignition to confirm results and sheck for reproducibility. In addition to temperature-time records, visual observations of events--such as evolution of smoke, charring, and smoldering-were also noted.

Sprinkle tests were also conducted to simulate very thin layers. In these tests, small amounts of dust were dropped from a spatula onto the preheated surface and the minimum hot-surface temperature at which glowing occurred was determined.

\section{Tests in Flammable Atmospheres}

For the tests in the flammable atmospheres, the hotplate was heated to a higit temperature of about $380^{\circ} \mathrm{C}$, with the aluminum base of the enclosure already in position. Then the stainless steel ring was filled with the test dust, and the plastic upper part of the enclosure, covered with a plastic film, was placed on top of the base. At the onset of ignition and smoldering in the layer, an airflow of about $11 \mathrm{~L} / \mathrm{min}$ was introduced into the enclosure and directed downward over the layer to promote development of substantial areas of glowing particles (approximately 25 to $50 \mathrm{~mm}$ in diameter). When this was accomplished, the air was replaced with a llammable methane-air atmosphere. Metered flows of methane and air were premixed, and the mixtures, containing anywhere fiom 7 $1010 \mathrm{pct}$ methane, were introduced into the enclosure near the dust layer at a rate of about $12 \mathrm{~L} / \mathrm{min}$. The desired gas concentration was established inside the enclosure within a minute. Sprinkle tests were also conducted in the flammable atmospheres. For these tests, the hotplate was first heated to a high temperature $\left(>350^{\circ} \mathrm{C}\right)$, a flammable atmosphere was introduced into the enclosure, and then the dust being tested was sprinkled onto the hotplate.

\section{Gas Sampling}

Gas samples were collected in evacuated glass sample tubes with the aid of a hypodermic needle. The samples were collected close to and above the dust laver, usually during periods of vapor and/or smoke evolution. These samples were then analyzed by gas chromatography. (ias samples were also collected inside the enclosure during the tests in flammable atmospheres. A long hypodermic needle was used to sample the space just above the dust layer.

\section{Weight Loss}

The oil shale or coal to be tested was preweighed. Usually a small amount of dust was left over after the stainless steel retaining ring was filled. This amount was also weighed and its weight subtracted from the original weight. Alter the test, the residue was usually left on the hotplate to cool and llen wats weighed. Any changes in layer weight were recorded. The weight of the layer was also used to calculate layer density. 


\section{HIGH-TEMPERATURE HOTPLATE $\left(>400^{\circ} \mathrm{C}\right)$}

A high-temperature surface was constructed from a circular heating coil used in electric ranges. The temperature of the coil was controlled by a seven-position switch. A 22- by 22- by $0.6-\mathrm{cm}$ stainless steel plate was positioned just above the coil on ceramic supports. The surface temperature of the plate was uneven and was not controlled other than by the switch setting. The outer perimeter of the metal plate was covered with thick insulating material to help maintain a more uniform temperature in the central portion of the plate where the samples were deposited.

At the two highest settings, which were used in almost all the tests, the surface temperature of the coil was abotit $720^{\circ}$ and $770^{\circ} \mathrm{C}$, and ihe surface temperature of the plate was about $470^{\circ}$ and $500^{\circ} \mathrm{C}$, respectively. Dusts were either sprinkled or piled on the prehealed plate surface without the use of a retaining ring. Thermocouples within the pile measured the approximate sample temperatures.

\section{TEST MATERIALS}

Four oil shale samples from the Green River Formation in Colorado and two Pittsourgh Sean coal samples were tested. The six dusts were analyzed, and the resultant Fischer assays, heating values, and particle sizes are presented for fine and coarse dusts, respectively, in table $2-1$. The two Pitusburgh coal samples were chosen for comparison purposes.
Table 2-1.-Analyses of oil shale and coal dusts

\begin{tabular}{|c|c|c|c|c|c|}
\hline \multirow{2}{*}{$\begin{array}{c}\text { Dust } \\
\text { sample' }\end{array}$} & \multirow{2}{*}{$\begin{array}{l}\text { Fischer } \\
\text { assay. } \\
\text { gal/ton }\end{array}$} & \multirow{2}{*}{$\begin{array}{l}\text { Heatıng } \\
\text { value, } \\
\text { Btu/lb }\end{array}$} & \multicolumn{2}{|c|}{ Mean diameter, $\mu \mathrm{m}$} & \multirow{2}{*}{$\begin{array}{c}\text { Minus } \\
200 \text { mesh. } \\
\text { wt pct }\end{array}$} \\
\hline & & & Surface $\left(\bar{D}_{\mathrm{s}}\right)$ & Mass $\left(\bar{D}_{w}\right)$ & \\
\hline \multicolumn{6}{|c|}{ FINE-SiLt UUST } \\
\hline \multicolumn{6}{|l|}{ Oil shale: } \\
\hline $5082 \ldots$ & 20 & 1,810 & 14 & 37 & 85 \\
\hline $6238 \ldots \ldots \ldots \ldots$ & 33 & 3.230 & 12 & 56 & 72 \\
\hline $5084 \ldots \ldots \ldots \ldots$ & 50 & 4,700 & 17 & 51 & 78 \\
\hline Plttsburgh coal .... & NAp & 13.800 & 32 & 50 & 80 \\
\hline \multicolumn{6}{|c|}{ COARSE-SIZE DUST } \\
\hline Oil shale $5933 \ldots .$. & 33 & 3.190 & -55 & 310 & 27 \\
\hline Pittsburgh coal .... & NAp & 14,040 & 115 & 460 & 14 \\
\hline
\end{tabular}

The oil shales ranged in grade from 20 gal/ton through 33 to $50 \mathrm{gal} / \mathrm{ton}$. The fine 33 -gal/ton oil shale was from the Colony Mine while all the other oil shales were from Anvil Points. The Pittsburgh Seam coal is a bituminous coal of high volatility. As seen in the table, about 80 pet of the fine samples pass through a 20() -mesh $(74-\mu m)$ screen, whereas less than 30 pet of the coarse samples pass through the same screen. The surface mean diameters $\left(\bar{D}_{2}\right)$ of the fine and coarse coal particles are about twice the size of the respective oil shale particles, while the mass mean diameters of the coal and oil shale samples are similar.

\section{EXPERIMENTAL RESULTS}

\section{MINIMUM HOT-SURFACE IGNITION TEMPERATURES}

The fine oil shale and coal dusts were tested in 10. em-diam layers with the following nominal thicknesses: 6.4, 12.7 , and $25.4 \mathrm{~mm}$. In addition, the 33 -gal ton oil shale was tested in a layer that was $38.1 \mathrm{~mm}$ thick and $12.7 \mathrm{~cm}$ in diameter. The coarse samples were tested in only a few selected layer thicknesses. All the experimental data were obtained in the form of temperature-time histories of the hotplate surface and of the dust layer at its geometric center and at its surface. Representative temperature-time profiles are shown in figures 2-4 $102-10$. In figure 2-4, two temperature-time profiles are shown for the 20-gal/ton oil shale, heated in a $12.7-\mathrm{mm}$-thick layer. The $1 \mathrm{~cm}$ peratures of the surface of the hotplate differ by $10^{\circ} \mathrm{C}$. In the test at $290^{\circ} \mathrm{C}$, the layer ignited; its temperature rose more than $50^{\circ} \mathrm{C}$ above the hotplate surface temperature. When the hotplate surface temperature was $10^{\circ} \mathrm{C}$ lower $\left(280^{\circ} \mathrm{C}\right)$, the dust layer did not ignite. Thus, the minimum hot-surface ignition temperature of the 12.7 -mm-thick layer of the 20 -gal/ton oil shale dust is $290^{\circ} \mathrm{C}$. The temperature-time profiles obtained for the three fine oil shales and for the fine coal dust, tested in 12.7-mm-thick layers at their minimum ignition temperatures, are shown in figure 2-5. Some points of interest in this ligure are the following:

- The higher the grade of the vil shale, the lower the minimum hot-surface ignition temperature.

- Following an initial rise, the temperatures inside the heated layers reached a plateau and then rose rapidly when the lavers ignited.

- The maximum temperatures attained by the various oil shales do not show at correlation with their erade.
- The coal dust, whose minimum ignition temperature, $240^{\circ} \mathrm{C}$, was similar to that of the 50 -galiton oil shale, $230^{\circ} \mathrm{C}$, also attained a similar maximum temperature inside the layer. The initial heating rates of both these samples were also comparable, but the coal required more time before rapid heating, began.

As previously shown, the minimum hot-surface ignition temperature of the 20 -gal/ton oil shale was $290^{\circ}$ ( when its layer thickness was $12.7 \mathrm{~mm}$. The same oil shale was also

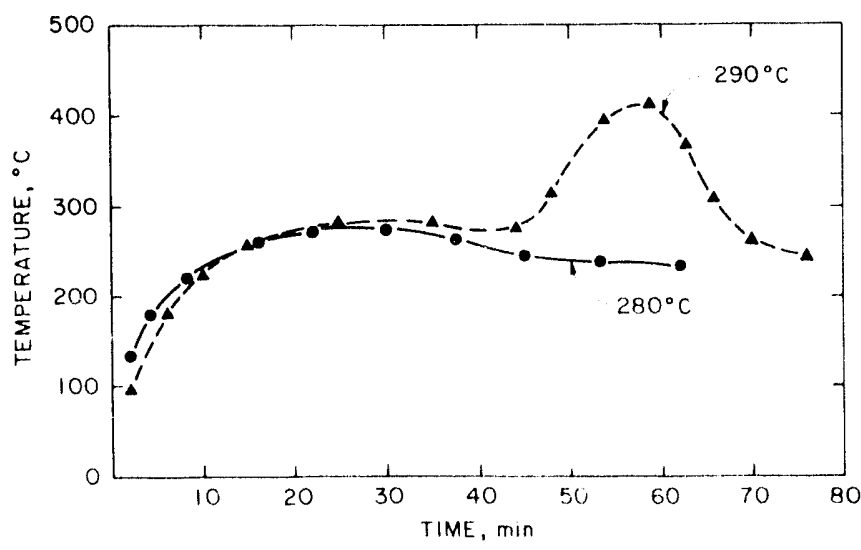

Figure 2-4. - Temperature-time profiles for 12.7-mm-thick layers of 20 -gat/ton oil shale at hotplate surface temperatures of $280^{\circ}$ and $290^{\circ} \mathrm{C}$. 


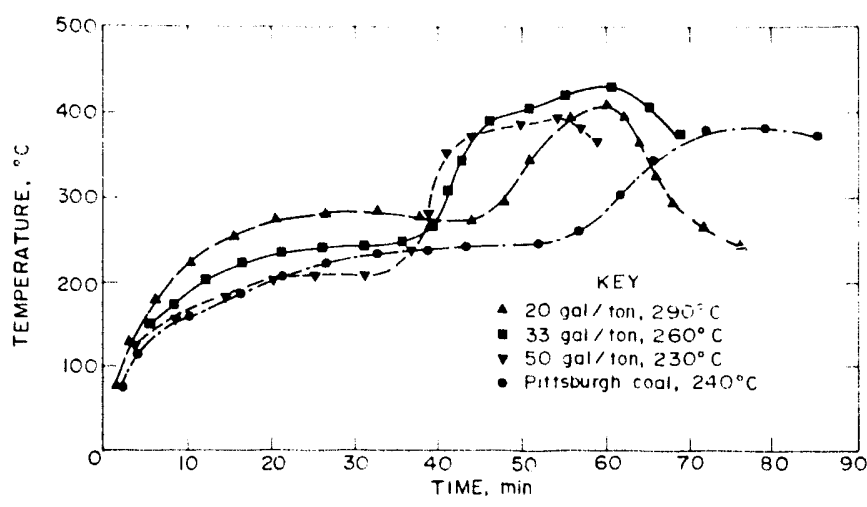

Figure 2-5. - Temperature-time profiles for 12.7-mm-thick layers of tine oil shale and coal dusts at minimum hotplate surface ignition temperatures.

heated at $300^{\circ}$ and $310^{\circ} \mathrm{C}$ during the process of finding the minimum ignition temperature. Temperature-time profiles recorded at $290^{\circ}, 300^{\circ}$, and $310^{\circ} \mathrm{C}$ are presented in figure 2-6. The samples heated at these three hot-surface temperatures all ignited, but less time was required for the initiation of the accelerated heating phase when the surface temperature was higher, as expected. The maximum temperatures attained inside the layers do not correlate directly with the surface temperatures of the hotplate. More likely, the maximum temperature is a function of the packing density of each layer and the resultant available oxygen inside the layer.

The temperature-time profiles for the thin, $6.4-\mathrm{mm}$ oil shale layers differ somewhat from those for the 12.7-mm-thick layers; instead of a plateau, the slow rise in temperature was followed by a drop in temperature, manifested as a shallow trough. The final, faster increase in the temperature of the layer came after this trough. The plots for the 33- and 20-gal/ton oil shales in figure 2-7 are typical. The thin layers of the $50 \mathrm{-gal} / \mathrm{ton}$ oil shale behaved in a similaı manner. Unlike the oil shales, the thin coal layer showed neither a plateau nor a trough, but only an uninterrupted rise to the peak temperature, as depicted in the figure.

The temperature-time histories for the $25.4-\mathrm{mm}$-thick layers that underwent ignition are largely similar to those observed with the $12.7-\mathrm{mm}$-thick layers, but in place of a plateau, the slow rise in temperature was directly succeeded by a period in which the temperature rise inside the layer occurred at an increased rate. This change in rate is evident as an upward bend in the plots, at times more pronounced than at others, as seen in figure $2-8$ for coal and for the $50-\mathrm{gal} / \mathrm{ton}$ oil shale, and in figure 2-9 for the $38.1-\mathrm{mm}$-thick layer of the 33-gal/ton oil shale. The temperature-time profile that was measured just under the surface is also included in figure 2-9 (and shown as "Surface"). This profile is fairly representative of many of the hotplate tests. The coincidence of smoke evolution with the very fast rise in temperature at the surface is also typical. The much longer time periods required for thick layers to ignite and reach maximum temperatures are slso seen in figures $2-8$ and 2-9. Finally, a temperature-time history for a $25.4-\mathrm{mm}$ layer of 50 -gal/ton oil shale, heated at a surface temperature of $380^{\circ} \mathrm{C}$ (much higher than the minimum ignition temperature of $200^{\circ} \mathrm{C}$ ) is presented in figure $2-10$.

The temperature-time histories for layers that did not ignite, regardless of thickness, are similar. The temperature rose slowly to a level that was in most cases below that of the hoiplate icmperature, and then the icinperature fell duc eventually reached a plateau, as shown in figure 2-4 for the

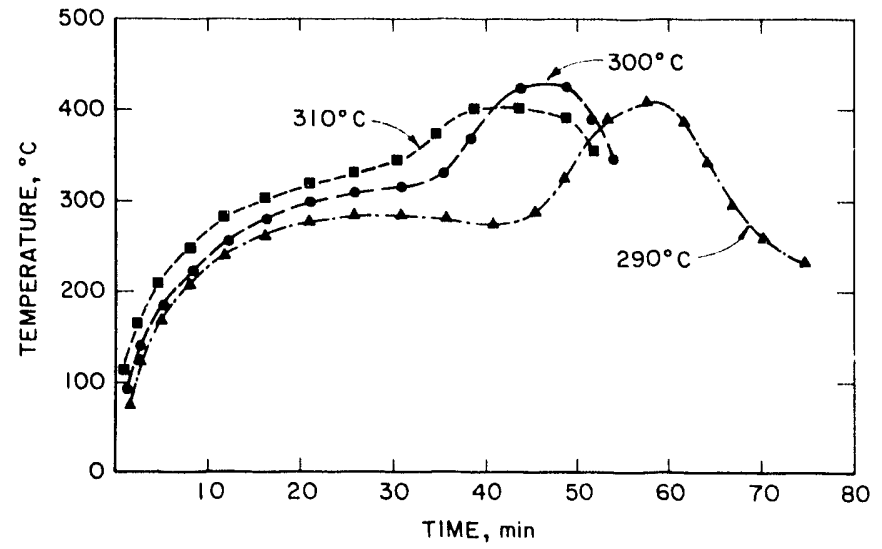

Figure 2-6. - Temperature-time profiles for 12.7-mm-thick laye:s of 20-gal/ton oil shale at several hotplate surface temperatures.

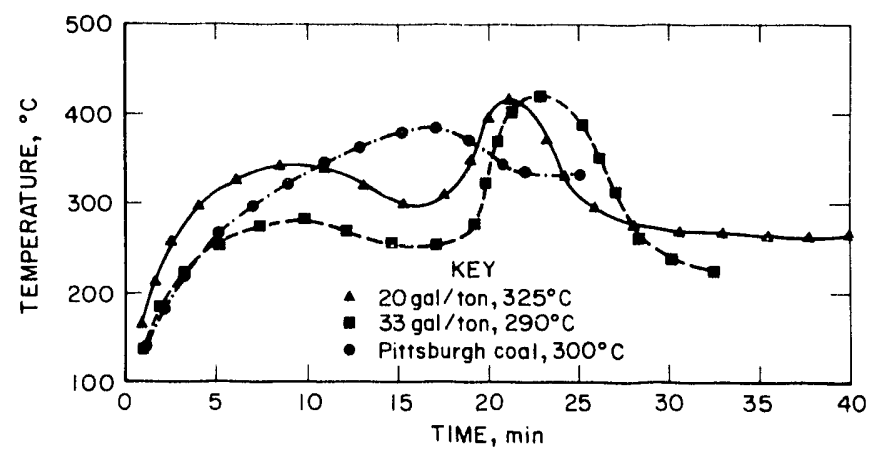

Figure 2-7.-Temperature-time profiles for 6.4-mm-thick layers of 20- and 33-gal/ton oil shales and Pittsburgh coal at minimum hotplate surface ignition temperatures.

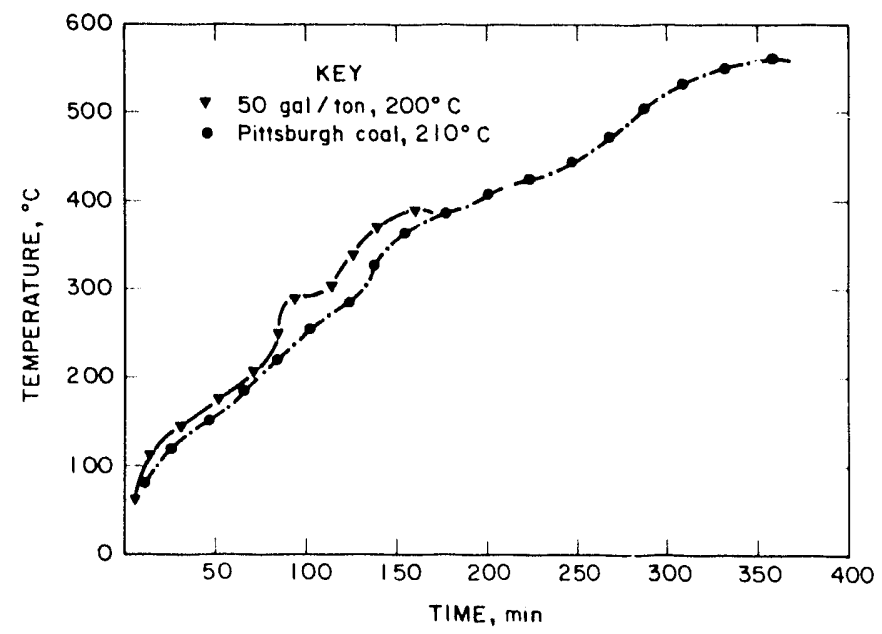

Figure 2.-8. - Temperature-time profiles for 25.4-mm-thick layers of $5 \mathrm{u}$-gaijiton oii shaie and Pitisburgh coai at minimum hotplate surface ignition temperatures. 


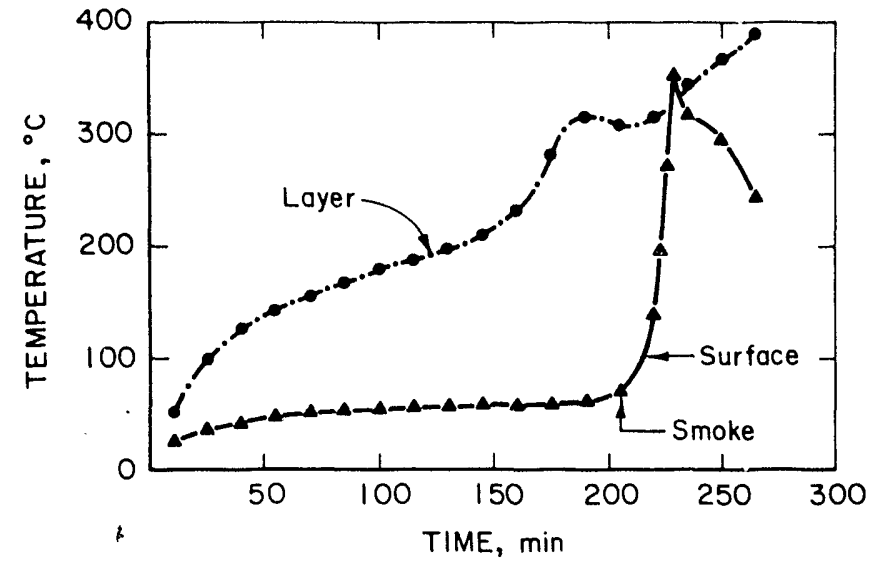

Figure 2-9.-Temperature-time profiles within layer and just under surface of $38.1-\mathrm{mm}$-thick layer of $33 \mathrm{gal} / \mathrm{ton}$ oil shale at minimum hotplate surface ignition temperature of $210^{\circ} \mathrm{C}$.

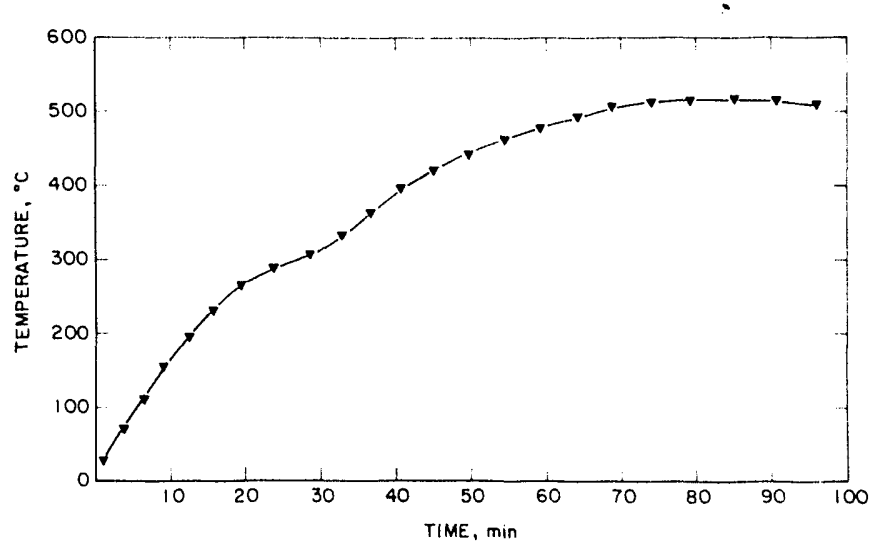

Figure 2-10.-Temperature-time profile for 25.4-mm-thick layer of $50-\mathrm{gal} /$ ton oil shale at hotplate surface temperature of $380^{\circ} \mathrm{C}$.

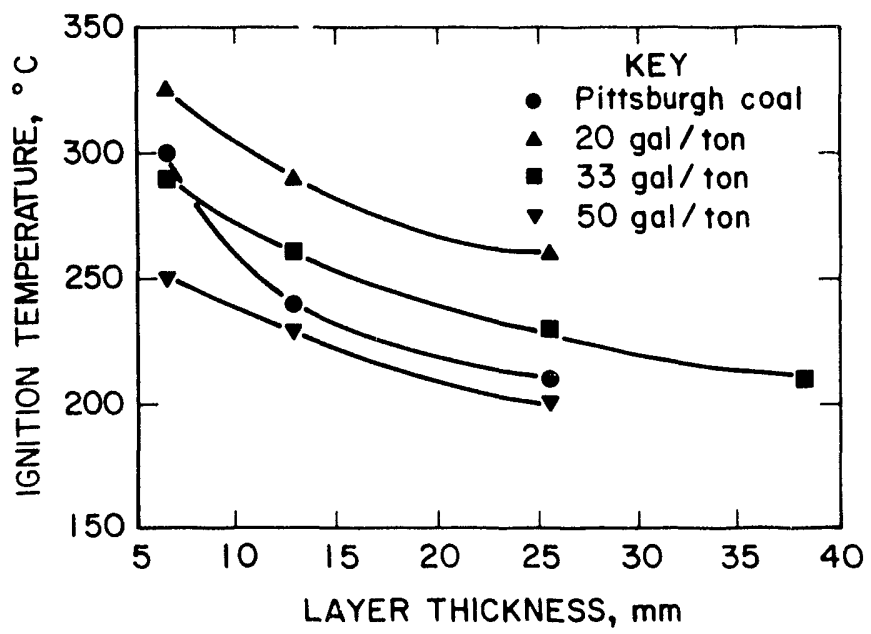

Figure 2-11.-Minimum hotplate surface ignition tempera-

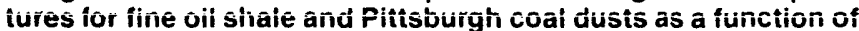
layer thickness.
20 -gal/ton oil shale. The time to reach this final plateau increased with increasing layer thickness.

The minimum hot-surface ignition temperatures for all the samples at the various layer thicknesses are summarized in table 2-2, which also includes the maximum temperatures that were reached inside the geometric centers of the layers for the respective hot-surface temperatures and the times to reach these maximum temperatures. The densities of the various layers are also shown in the table. Minimum ignition temperatures were not determined for the coarse dusts. The maximum hot-surface temperatures at which these dusts were tested are shown in the table, as well as the respective maximum temperatures attained within the layers at these hot-surface temperatures. The relationship between the minimum ignition temperature and layer thickness is shown in figure 2-11.

Table 2-2.-Minimum hotplate surface ignition temperatures of oil shale and coal dust layers $(10 \mathrm{~cm}$ in diam)

\begin{tabular}{|c|c|c|c|c|}
\hline $\begin{array}{l}\text { Layer } \\
\text { thickness } \\
\text { and dust } \\
\text { sample }\end{array}$ & $\begin{array}{l}\text { Layer } \\
\text { density, } \\
\mathrm{g} / \mathrm{cm}^{3}\end{array}$ & $\begin{array}{c}\text { Minimum } \\
\text { hotplate surface } \\
\text { ignition } \\
\text { temperature, } \\
{ }^{\circ} \mathrm{C}\end{array}$ & $\begin{array}{c}\text { Maximum } \\
\text { temperature } \\
\text { within layer,' } \\
{ }^{\circ} \mathrm{C}\end{array}$ & $\begin{array}{c}\text { Time to } \\
\text { maximum } \\
\text { temperature, } \\
\text { min }\end{array}$ \\
\hline \multicolumn{5}{|c|}{ FINE-SIZE DUST } \\
\hline \multicolumn{5}{|l|}{$6.4 \mathrm{~mm}$} \\
\hline \multicolumn{5}{|l|}{ Oil shale: } \\
\hline 20-gal/ton ................ & 0.69 & 325 & 425 & 21 \\
\hline 33-galiton............... & .62 & 290 & 420 & 23 \\
\hline 50-gal/ton ................. & .55 & 250 & 419 & 20 \\
\hline $\begin{array}{c}\text { Pittsburgh coal ........... } \\
12.7 \mathrm{~mm}\end{array}$ & .52 & 300 & 385 & 15 \\
\hline \multicolumn{5}{|l|}{ Oil shale: } \\
\hline $20-\mathrm{gal} / \mathrm{ton} . . . \ldots \ldots \ldots$ & .78 & 290 & 411 & 59 \\
\hline 33-gal/ton ................ & .63 & 260 & 436 & 60 \\
\hline 50-gal/ton ................ & .62 & 230 & 397 & 49 \\
\hline $\begin{array}{l}\text { Pittsburgh coal ............ } \\
25.4 \mathrm{~mm}\end{array}$ & .52 & 240 & 386 & 77 \\
\hline \multicolumn{5}{|l|}{ Oil shale: } \\
\hline 20-gal/ton ............... & .83 & 260 & 383 & 147 \\
\hline 33-gal/ton ............... & .63 & 230 & 482 & 163 \\
\hline 50-gal/ton .................. & .64 & 200 & 392 & 158 \\
\hline $\begin{array}{c}\text { Pittsburgh coal ............ } \\
38.1 \mathrm{~mm}^{2}\end{array}$ & .55 & 210 & 560 & 363 \\
\hline Oil shale: 33 -gal/ton ... & .74 & 210 & $>389$ & $\left({ }^{3}\right)$ \\
\hline \multicolumn{5}{|c|}{ COARSE-SIZE DUST } \\
\hline $12.7 \mathrm{~mm}$ & & & & \\
\hline Oil shale: $33-\mathrm{gal} / \mathrm{ton} \ldots$ & 0.97 & $>390$ & 405 & ${ }^{4} 24$ \\
\hline $\begin{array}{l}\text { Pittsburgh coal ........... } \\
\qquad 25.4 \mathrm{~mm}\end{array}$ & .77 & $>380$ & 373 & 547 \\
\hline 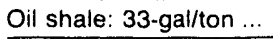 & 1.02 & $>390$ & 383 & ${ }^{4} 69$ \\
\hline $\begin{array}{l}\text { Al geometric center } \\
212.7 \mathrm{~cm} \text { in diam. } \\
3 \text { Terminated at } 263 \mathrm{n} \\
{ }^{4} \text { Smoke was evolved } \\
{ }^{5} \text { No visible change }\end{array}$ & n. & ale underwent a & smoldering re & ction. \\
\hline
\end{tabular}

The main objective of the tests was to determine the minimum hot-surface ignition temperatures of the dust layers. In general, this value for a given dust and layer thickness can be determined in a reasonable number of tests. As seen in table $2-3$, which summarizes results for all the tests of 12.7$\mathrm{mm}$-thick layers of the $20 \mathrm{-gal} /$ ton oil shale, tests at $250^{\circ}$, $280^{\circ}$, and $290^{\circ} \mathrm{C}$ were sufficient to determine the minimum hot-surface ignition temperature. However, hotplate tests for many of the samples were also conducted over a much wider range of temperatures, including temperatures well above the minimum ignition temperatures. This was done in order to assess the fire hazards under such conditions. For example, the $12.7-\mathrm{mm}$ layers of the lean oil shale were tested at surface 
temperatures that ranged from $250^{\circ}$ to $378^{\circ} \mathrm{C}$. Intormation garnered in the tests is presented in table 2-3, including layer temperature at the time smoke was observed.

In addition to the ignition criterion of a rise in the temperature of a layer of at leas $50^{\circ} \mathrm{C}$ above the hotplate surface temperature, another criterion is that of visible evidence of combustion, surh as red glow or flame. However, flaming combustion was not observed in any of the tests with the six samples, even at hot-surface temperatures well above the minimum ignition temperatures. Cilowing ; articles were observed only in the tests with the 50 -gal/ton oil shale, most often with the thin, $6.4-\mathrm{mm}$ layers. Glowing was due to the oxidation of char on the layer surface, at edges or near cracks. A residue of ash was left after the glow.

The ignition process in a 12.7-mm-thick layer during one of the tests with the $50-\mathrm{gal} /$ ton oil shale dust is seen in figure 2-12. The black spots on the surface are the locations of reacting areas $(2-12 B$ to $D)$. At the end of the test $(2-12 D)$, the whole layer is black, owing to conversion of the kerogen to char. The volatiles coming off the layer are also discernible.

Table 2-3. - Hotplate test results for $12.7-\mathrm{mm}$-thick layers of $20-\mathrm{gal} /$ ton oil shale dust

\begin{tabular}{|c|c|c|c|c|c|c|c|}
\hline \multirow{3}{*}{$\begin{array}{l}\text { Hotplate } \\
\text { surface } \\
\text { temperature. } \\
{ }^{\circ} \mathrm{C}\end{array}$} & \multicolumn{4}{|c|}{ Vapor or smoke' } & \multirow{3}{*}{$\begin{array}{l}\text { Maximum } \\
\text { temperature } \\
\text { within layer, } \\
{ }^{\circ} \mathrm{C}\end{array}$} & \multirow{3}{*}{$\begin{array}{c}\text { Time } \\
\text { to } \\
\text { maximum } \\
\text { temperature, } \\
\text { min }\end{array}$} & \multirow{3}{*}{$\underset{{ }^{\circ} \mathrm{C}}{\Delta \max ^{3}}$} \\
\hline & \multicolumn{2}{|c|}{ Appearance } & \multicolumn{2}{|c|}{ Termination } & & & \\
\hline & $\begin{array}{c}\text { Temperature }{ }^{2} \\
{ }^{\circ} \mathrm{C}\end{array}$ & $\begin{array}{c}\text { Time. } \\
\text { min }\end{array}$ & $\begin{array}{c}\text { Temperature. }{ }^{2} \\
{ }^{\circ} \mathrm{C}\end{array}$ & $\begin{array}{c}\text { Time, } \\
\min \end{array}$ & & & \\
\hline 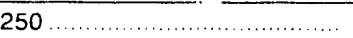 & ND & ND & ND & ND & 203 & 22 & -47 \\
\hline 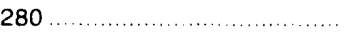 & 214 & 10 & 260 & 32 & 263 & 26 & -17 \\
\hline $280 \ldots \ldots \ldots \ldots$ & ND & ND & ND & ND & 276 & 26 & -4 \\
\hline $290 \ldots \ldots \ldots \ldots$ & 180 & 6 & ${ }^{4} 200$ & 86 & 411 & 59 & 121 \\
\hline $300 \ldots \ldots \ldots \ldots$ & 189 & 5 & 420 & 43 & 429 & 48 & 129 \\
\hline 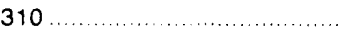 & 198 & 4 & 401 & 43 & 401 & 42 & 91 \\
\hline $350 \ldots \ldots \ldots \ldots$ & ${ }^{5} 65$ & 1 & 429 & 26 & 458 & 39 & 108 \\
\hline $378 \ldots \ldots \ldots \ldots \ldots \ldots \ldots \ldots \ldots \ldots \ldots \ldots \ldots \ldots \ldots \ldots \ldots \ldots$ & ${ }^{5} 68$ & 1 & 462 & 29 & 478 & 40 & 100 \\
\hline \multicolumn{8}{|l|}{$\begin{array}{l}\text { ND Not detected. } \\
1 \text { Vapor is white, whereas sn } \\
2 \text { At geometric center. } \\
{ }^{3} \text { Difference between maxim }\end{array}$} \\
\hline
\end{tabular}
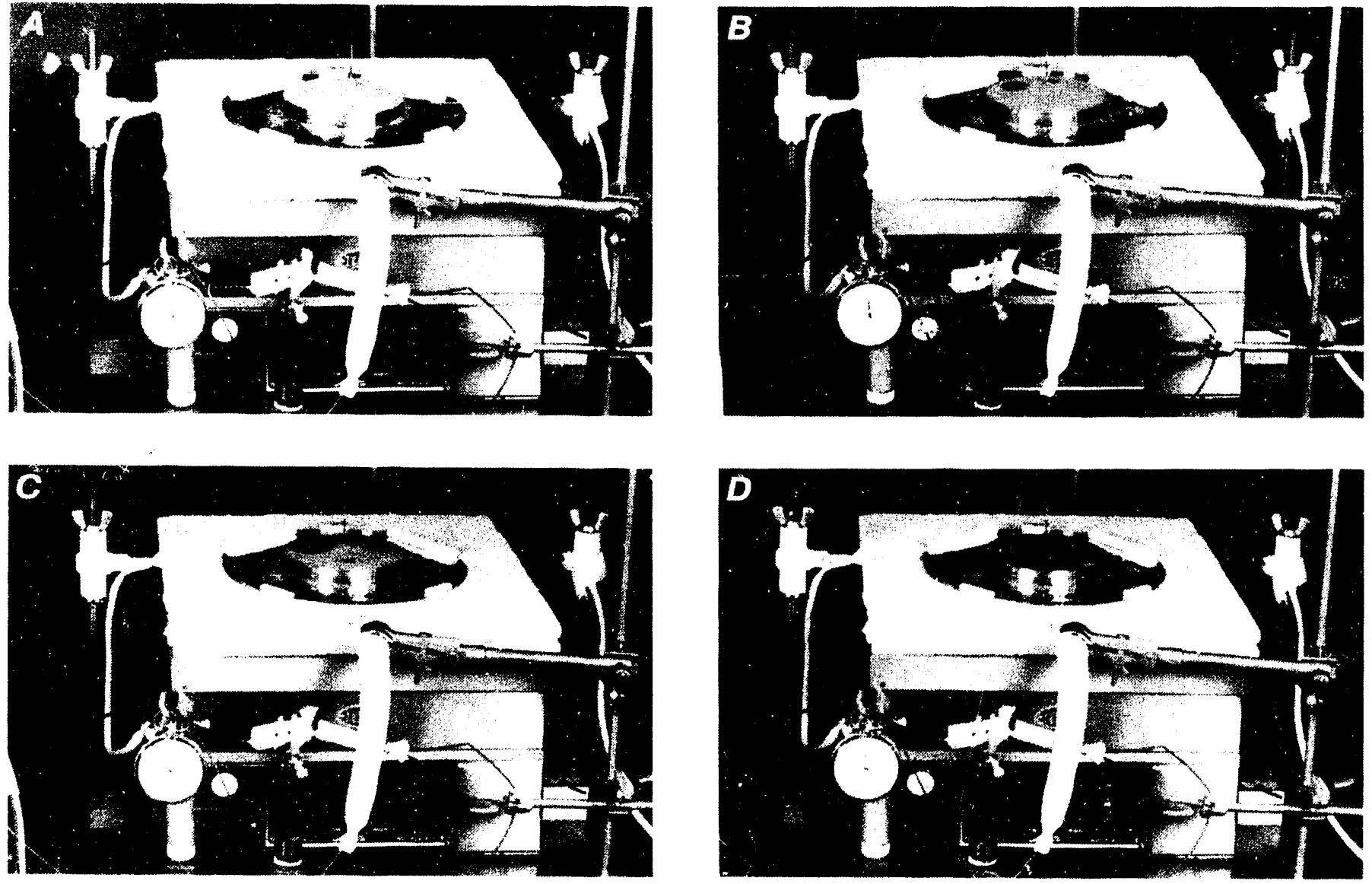

Figure 2-12. - Typical hotplate test showing ignition process in $12.7-\mathrm{mm}$-thick layer of 50-gal/ton oil shale dust. 


\section{MAXIMUM TEMPERATURES ATTAINED INSIDE LAYERS}

As was indicated in the previous section, tests were also conducted at surface temperatures much higher than the minimum ignition temperatures of the layers. The intent was to determine the highest temperatures that would be attained within the various layers, and at the same time, to look for signs of visible combustion, such as flame or glowing particles. Such information is helpful in the assessment of possible fire hazards of ignited layers. Detailed results showing maximum temperatures for the various samples at selected layer thicknesses as a function of the hot surface temperature are given in the appendix to part 2 . Pertinent values were chosen from these tables and combined in table 2-4.

Table 2-4.-Maximum layer temperatures attained in various tests (fine-size dust)

\begin{tabular}{|c|c|c|c|c|}
\hline $\begin{array}{c}\text { Dust } \\
\text { sample }\end{array}$ & $\begin{array}{c}\text { Layer } \\
\text { thickness, } \\
\mathrm{mm}\end{array}$ & $\begin{array}{c}\text { Hotplate } \\
\text { surface } \\
\text { temperature. } \\
{ }^{\circ} \mathrm{C} \\
\end{array}$ & $\begin{array}{c}\text { Maximum } \\
\text { temperature } \\
\text { within layer, }{ }^{1} \\
{ }^{\circ} \mathrm{C}\end{array}$ & $\underset{{ }^{\circ} \mathrm{C}}{\mathrm{T} \max }{ }^{2}$ \\
\hline \multicolumn{5}{|l|}{ Oil shale: } \\
\hline \multirow[t]{3}{*}{ 20-gal/ton .......... } & 6.4 & 320 & 356 & 36 \\
\hline & & 325 & 425 & 100 \\
\hline & & 350 & 442 & 92 \\
\hline \multirow[t]{2}{*}{ Do .................. } & 25.4 & 250 & 264 & 14 \\
\hline & & 260 & 383 & 123 \\
\hline \multirow[t]{3}{*}{ 33-gal/ton .......... } & 12.7 & 250 & 231 & -19 \\
\hline & & 260 & 436 & 176 \\
\hline & & 270 & 456 & 186 \\
\hline Do ................... & 25.4 & 230 & 482 & 252 \\
\hline \multirow[t]{5}{*}{50 -gal/ton .......... } & 25.4 & 200 & 392 & 192 \\
\hline & & 220 & 397 & 177 \\
\hline & & 240 & 439 & 199 \\
\hline & & 260 & 403 & 143 \\
\hline & & 378 & 520 & 142 \\
\hline \multirow[t]{4}{*}{ Pittsburgh coal ..... } & 6.4 & 280 & 310 & 30 \\
\hline & & 300 & 385 & 85 \\
\hline & & 310 & 392 & 82 \\
\hline & & 330 & 424 & 94 \\
\hline \multirow[t]{2}{*}{ Do. } & 25.4 & 210 & 560 & 350 \\
\hline & & 380 & 566 & 186 \\
\hline
\end{tabular}

\footnotetext{
At geometric center

${ }^{2}$ Difference between maximum temperature attained at geometric center of layer and hot-surface temperature.
}

It is apparent from the data in table 2-4 and in the appendix that in almost all the tests the maximum temperatures registered at the geometric center of the layers were less than $500^{\circ} \mathrm{C}$. In most of the tests the maximum temperaiures were less than $450^{\circ} \mathrm{C}$, for both the oil shales and the coal, even when the hotplate surface temperatures were high. The few exceptions in which temperatures greater than $500^{\circ} \mathrm{C}$ were seen were tests with $25.4-\mathrm{mm}$-thick layers of the $50-\mathrm{gal} /$ ton oil shale and of coal. The oil shale required a high hotplate surface temperature $\left(-380^{\circ} \mathrm{C}\right)$ to achieve a temperature above $500^{\circ} \mathrm{C}$, while the coal sample reached $560^{\circ} \mathrm{C}$ when heated at a hotplate temperature of $210^{\circ} \mathrm{C}$. The coal layer sagged, especially at the center, and lost almost $27 \mathrm{pct}$ of its original weight; some ash formed as well. When the same layer thickness of coal $(25.4 \mathrm{~mm})$ was heated on a $380^{\circ} \mathrm{C}$ hot surface, essentially the same maximum temperature, $566^{\circ} \mathrm{C}$. was recorded. However, less time was required to reach this point.
The dust layers did not undergo flaming combustion in any of the tests. Glowing combustion was observed only in some of the tests with the $50-\mathrm{gal} /$ ton oil shale layers and occurred most often with the 6.4-mm-thick layers.

\section{EFFECT OF LAYER CONFINEMENT}

The hotplate test procedure specifies the use of a metal ring of a known size and thickness for the confinement of the sample during the tests. But dust layers accumulating on equipment surfaces can be unconfined as well. A few tests were conducted to observe the behavior of unconfined layers. The unconfined layers were prepared in the usual manner, with a standard ring, and then the ring was carefully removed. The fine oil shale dusts tended to stick together and retain their layer shape, even without the support of a ring. The coal dust lacked this sticking tendency, and upon removal of the ring, fine cracks developed in the layer. The cracks and open sides permitted easier diffusion of air into the heated layer, and as a result, the layer attained somewhat higher maximum temperatures. However, the minimum hot-surface ignition temperature for the coal layer remained the same as for the confined layer. The minimum hot-surface ignition temperature of the $12.7-\mathrm{mm}$ layer of $50-\mathrm{gal} / \mathrm{ton}$ oil shale likewise was not changed by the absence of the ring.

\section{PARTICLE SIZE EFFECTS}

Previous work by the Bureau (12) documented the effect of particle size on the minimum hot-surface ignition temperature of coal dust layers, namely, that coarser particles had a higher minimum ignition temperature. In order to see if oil shale behaved in a similar manner, fine and coarse oil shale dusts of the same richness, $33 \mathrm{gal} / \mathrm{ton}$, were tested. The tests with the coarse material were done at a layer thickness of 12.7 $\mathrm{mm}$. None of the coarse dust layers ignited according to the ignition criteria of the test, even when heated on surfaces whose temperatures were as high as $390^{\circ} \mathrm{C}$. The minimum hot-surface ignition temperature for $12.7-\mathrm{mm}$-thick layers of the fine $33-\mathrm{gal} / \mathrm{ton}$ dust was $260^{\circ} \mathrm{C}$.

The maximum temperatures achieved inside the coarse shale layers at their geometric centers are presented in table 2-5. From these results, it is somewhat difficult to predict the minimum hot-surface ignition temperature (i.e., $\Delta T \max >50^{\circ} \mathrm{C}$ ) of this oil shale for this layer thickness. One test of the coarse sample at a layer thickness of $25.4 \mathrm{~mm}$ and at a hot-surface temperature of about $390^{\circ} \mathrm{C}$ also did not result in ignition; the maximum temperature measured inside the layer was $383^{\circ} \mathrm{C}$.

Table 2-5.-Hotplate test results for $12.7-\mathrm{mm}$-thick layers of coarse 33-gal/ton oil shale dust

\begin{tabular}{|c|c|c|c|}
\hline $\begin{array}{c}\text { Hotplate } \\
\text { surface } \\
\text { temperature, } \\
{ }^{\circ} \mathrm{C}\end{array}$ & $\begin{array}{c}\text { Maximum } \\
\text { temperature } \\
\text { within layer, } \\
{ }^{\circ} \mathrm{C}\end{array}$ & $\begin{array}{c}\text { Time to } \\
\text { maximum } \\
\text { temperature, } \\
\text { min }\end{array}$ & 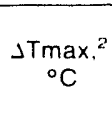 \\
\hline $230 \ldots \ldots \ldots \ldots \ldots \ldots \ldots \ldots$ & 204 & 49 & -26 \\
\hline $255 \ldots \ldots \ldots \ldots \ldots \ldots$ & 229 & 26 & -26 \\
\hline $267 \ldots \ldots \ldots \ldots \ldots \ldots \ldots \ldots$ & 247 & 27 & -20 \\
\hline $275 \ldots \ldots \ldots$ & 253 & 27 & -22 \\
\hline $290 \ldots \ldots \ldots \ldots \ldots \ldots \ldots \ldots \ldots$ & 283 & 32 & -7 \\
\hline $310 \ldots \ldots \ldots \ldots \ldots \ldots \ldots \ldots$ & 309 & 32 & -1 \\
\hline $350 \ldots \ldots \ldots \ldots \ldots \ldots \ldots \ldots \ldots$ & 374 & 32 & 24 \\
\hline 390 & 405 & 24 & 15 \\
\hline
\end{tabular}


Coarse Pittsburgh coal behaved in the same manner as did the coarse oil shale; it did not ignite, even at high surface temperatures. In two tests with $12.7-\mathrm{mm}$ layers at hotplate temperatures of $300^{\circ}$ and $380^{\circ} \mathrm{C}$, the maximum temperatures attained inside the centers of the layers were 27()$^{\circ}$ and $373^{\circ} \mathrm{C}$. respectively. At the same laver thickness, the minimum hotsurface ignition temperature of the fine coal dust was $240^{\circ} \mathrm{C}$.

During the tests with the coarse 33 -gal/ton oil shale, it was noted that the packing density of this dust $\left(0.97 \mathrm{~g} / \mathrm{cm}^{3}\right)$ was higher than the density of the fine $33-\mathrm{gal} / \mathrm{ton}$ oil shale $\left(0.63 \mathrm{~g} / \mathrm{cm}^{3}\right)$. To eliminate the possibility that the packing density influenced the results, layers of the fine dust were pressed by hand to increase their density to $0.79 \mathrm{~g} / \mathrm{cm}^{3}$. These layers were prepared before the tests. The ring was placed on a piece of fine aluminum foil and filled with the dust, and the dust was compressed. The compressed dust laver in the ring. along with the foil, was slid onto the preheated hotplate. The layer thermocouple was not used in these tests. Instead, a fine thermocouple was inserted into the layer with its junction at about the geometric center of the layer. For the compressed layer. the minimum hot-surface ignition temperature was $270^{\circ} \mathrm{C}$, as compared with $260^{\circ} \mathrm{C}$ for the uncompressed layer. Thus, layer density has a relatively minor effect on the minimum ignition temperature as compared with the effect of particle size.

\section{WEIGHT LOSS}

Weight loss values for $12.7-\mathrm{mm}$-thick layers of 20- and 5()-gal/ton oil shale dusts heated at various temperatures are shown ir table 2-6. The minimum ignition temperature of the

Table 2-6. -Weight losses for 12.7-mm-thick layers of 20- and 50-gal/ton oil shale dusts

\begin{tabular}{|c|c|}
\hline $\begin{array}{l}\text { Hotplate surtace } \\
\text { temperature, }{ }^{\circ} \mathrm{C}\end{array}$ & Weight los \\
\hline \multicolumn{2}{|l|}{ 20.gal/ton oll shale. } \\
\hline $250 \ldots \ldots \ldots$ & 1.2 \\
\hline 280 & 1.7 \\
\hline 280 & 2.3 \\
\hline$\ldots \ldots \ldots \ldots \ldots$ & 5.2 \\
\hline 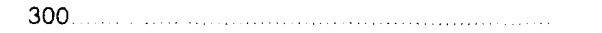 & 5.6 \\
\hline 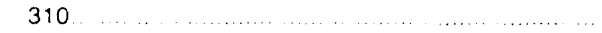 & 6.3 \\
\hline$\ldots \ldots \ldots \ldots \ldots \ldots \ldots \ldots \ldots \ldots \ldots \ldots \ldots \ldots \ldots \ldots \ldots \ldots \ldots$ & 9.0 \\
\hline \multicolumn{2}{|l|}{ 50-gal,ton oll shale: } \\
\hline$(\ldots \ldots \ldots \ldots, \cdots, \ldots \ldots \ldots \ldots$ & .2 \\
\hline$\ldots \ldots \ldots \ldots \ldots \ldots \ldots \ldots \ldots \ldots \ldots \ldots \ldots$ & 12.7 \\
\hline 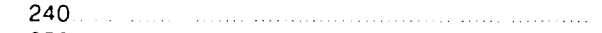 & 14.2 \\
\hline$\ldots \ldots \ldots \ldots \ldots$ & 152 \\
\hline$\ldots \ldots \ldots \ldots \ldots \ldots$ & 16.5 \\
\hline 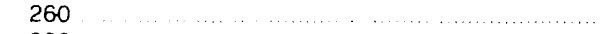 & 16.2 \\
\hline$\ldots \ldots \ldots \ldots \ldots$ & 17.6 \\
\hline 404 & 258 \\
\hline
\end{tabular}

Table 2-7.-Results of hotplate tests with $6.4-\mathrm{mm}$-thick layers of $50-\mathrm{gal} / \mathrm{ton}$ oil shale dust

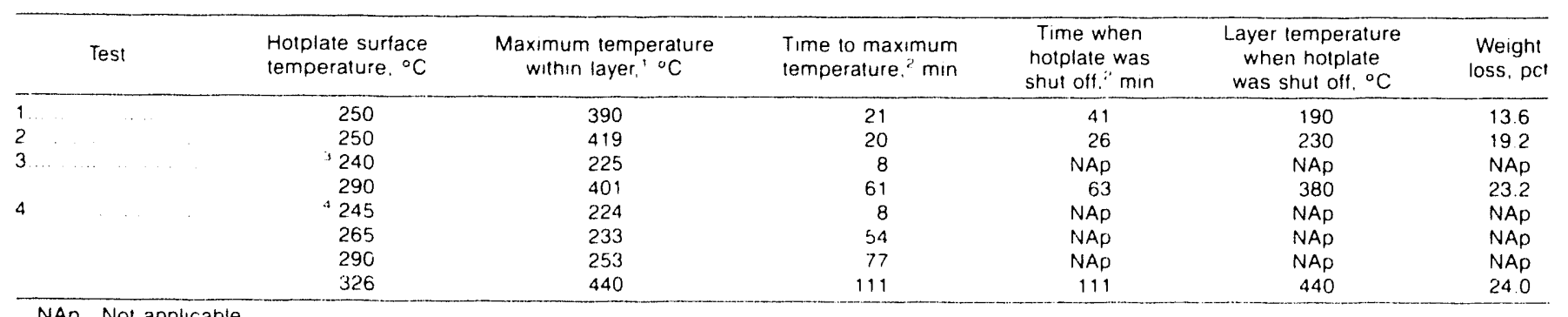

20-gal/ton oil shale at this layer thickness is $290^{\circ} \mathrm{C}$. But even at the lower temperatures there is a small weight loss, most probably due to loss of moisture. The minimum ignition temperature for the 50 -galion sample is $230^{\circ} \mathrm{C}$; a small weight loss was found at $205^{\circ} \mathrm{C}$. The data claarly show the dependence of the extent of kerogen decomposition on the temperature of the hotplate.

Weight losses were also determined in tests with the 6.4-mm layers of the 50 -gal/ton oil shale at the minimum ignition temperature of $250^{\circ} \mathrm{C}$ and at temperatures just below this value. The results for these tests, shown in table 2-7, indicate that in addition to the hot-surface temperature, the heating time at any specific temperature or temperature range influences weight loss. Comparison of the results with those shown in table 2-6 suggests that layer thickness can also alfect tests 2 and 4 from table $2-7$ are depicted in figure 2-13. The profiles show that both layers attained a temperature of $-250^{\circ} \mathrm{C}$ before they ignited. However, a much higher hotplate surface temperature of $326^{\circ} \mathrm{C}$ was required to ignite the layer in test 4 , in which a lower heating rate was used. oil shale were analyzed for their heating values with an adiabatic bomb calorimeter. The results of these tests together with additional pertinent information are as follows:

\begin{tabular}{|c|c|c|}
\hline & Resudue' I & Residue' \\
\hline Hotplate surfate temperature & 280 & 350 \\
\hline $\begin{array}{l}\text { Mavimum temperalure withm laver, measured al } \\
\text { geometric center .............................. }{ }^{\circ} \mathrm{C} \text {. }\end{array}$ & 26.3 & 458 \\
\hline Residue heating value ..................... But th.. & 1.390 & 210 \\
\hline 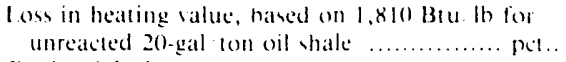 & 23.4 & 88.3 \\
\hline 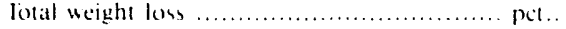 & 1.7 & 9.0 \\
\hline $\begin{array}{l}\text { kerogen weight loss (portion of kerogen that } \\
\text { decomposed to volatiles), based on kerogen } \\
\text { content of } 11 \text { wi pet ............................ pet. }\end{array}$ & 15.5 & 81.8 \\
\hline
\end{tabular}

The losses in kerogen content should be similar to the respective losses in heating values, but they are somewhat lower. The kerogen content of this raw oil shale is not known accurately and could be less than 11 pct; this would partly explain the disparity. Another uncertainty in the kerogen weight loss values arises from their mode of calculation; they are determined from relatively small differences between two large numbers. Loss of moisture should increase the total weight loss, and hence kerogen weight loss, without affecting the loss in heating value. However, oil shales in general contain very small amounts of moisture, and moisture loss could be neglected. On the whole, though, agreement is quite good.

The results show that a hotplate temperature of $350^{\circ}($, which generated a maximum temperature close to $460^{\circ} \mathrm{C}$ the extent of decomposition. Temperature-time profiles for

Two residues from $12.7-\mathrm{mm}$ layer tests of the 20 -gal/ton

From start of test.

${ }^{3}$ For $38 \mathrm{~min}$. then slowly raised to $290^{\circ} \mathrm{C}$

${ }^{4}$ For $37 \mathrm{~min}$, then slowiv raised in stages $10265^{\circ}$. $290^{\circ}$ and $326^{\circ} \mathrm{C}$ 


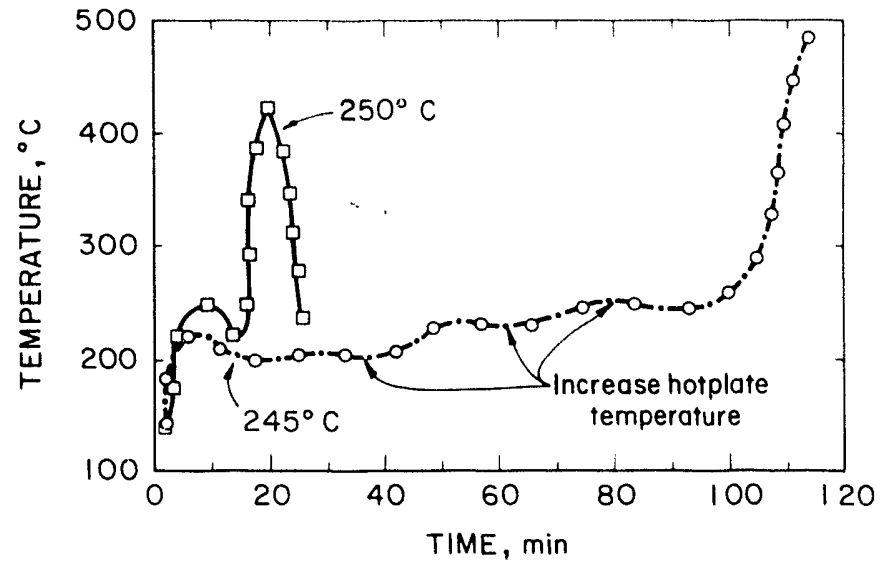

Figure 2-13.-Temperature-time profiles for 6.4-mm-thick layers of $50-\mathrm{gal} /$ ton oil shale at two hotplate surface temperatures.

inside the laver, sufficed to decompose most of the kerogen. Even during retorting, when much higher temperatures are attained, the kerogen does not decompose completely into gas and oil. Part of it converts to char that remains within the spent shale.

The coarse 33-gal/ton oil shale was evaluated at a 12.7 $\mathrm{mm}$ layer thickness, for a range of surface temperatures from $230^{\circ}$ to $390^{\circ} \mathrm{C}$. None of the samples ignited, according to the ignition criteria of this test. Nonetheless, at the higher hotplate surface temperatures the samples reacted and emitted vapors and smoke. Reactions were also evident in the color changes of the oil shale from beige to black (char formation) and to gray-black (a char-ash mixture). Yet, weight losses in all the tests were small, of the order of 1 to 3 pet.

For coal dust layers that did not ignite, very small weight losses were also observed. In a few of the coal layers, very small weight gains were recorded because of surface oxidation. The coal sample that did lose appreciable weight was the 25.4mm-thick layer that ignited and reached a maximum temperature of $560^{\circ} \mathrm{C}$. Weight loss was $26.8 \mathrm{pct}$. A change in volume also occurred and the coal layer collapsed, especially in the central portion. Such changes did not appear in any of the oil shale samples, although a small degree of shrinkage in the thickness and in the diameter of some of the layers did take place.

\section{GAS SAMPLES}

Gas samples were collected above the layers in some of the tests, usually during the emission of gases and/or smoke. These reaction products are diluted by the ambient atmosphere as soon as they emerge from the layer. Additional dilution occurred during sampling with a fine hypodermic needle. As a result, the combustion products constitute a very small part of any gas sample, and the results serve only to identify the gases that form and their relative concentrations. The height above the dust layer at which the sample was taken and the sampling time were kipt as uniform as possible. Some results of the analyses of these gas samples are presented in tables 2-8 and 2-9 for oil sha'e and in table 2-10 for coal.

Table 2-8. - Gas analyses results for samples collected above $12.7-\mathrm{mm}$ li'yers of $20-\mathrm{gal} / \mathrm{ton}$ oil shale dust

\begin{tabular}{|c|c|c|c|c|c|c|c|c|c|c|c|c|c|}
\hline \multirow{3}{*}{$\begin{array}{l}\text { Hotplate surface } \\
\text { temperature, } \\
{ }^{\circ} \mathrm{C}\end{array}$} & \multirow{3}{*}{$\begin{array}{l}\text { Layer temperature } \\
\text { at time of } \\
\text { sampling. }{ }^{1}{ }^{\circ} \mathrm{C}\end{array}$} & \multicolumn{11}{|c|}{ Concentration } & \multirow{3}{*}{$\begin{array}{c}\mathrm{CO}_{2} \cdot \mathrm{CO} \\
\text { ratio }\end{array}$} \\
\hline & & \multicolumn{5}{|c|}{ vol pct } & \multicolumn{6}{|c|}{ ppm } & \\
\hline & & $\mathrm{O}_{2}$ & $\mathrm{Ar}$ & $\mathrm{N}_{2}$ & $\mathrm{CO}_{2}$ & $\mathrm{CO}$ & $\mathrm{CH}_{4}$ & $\mathrm{C}_{2} \mathrm{H}_{6}$ & $\mathrm{C}_{2} \mathrm{H}_{4}$ & $\mathrm{C}_{2} \mathrm{H}_{2}$ & $\mathrm{C}_{3} \mathrm{H}_{8}$ & $\mathrm{C}_{3} \mathrm{H}_{6}$ & \\
\hline $300 \ldots \ldots \ldots \ldots \ldots \ldots$ & 308 & 20.7 & 0.93 & 78.18 & 0.15 & 0.04 & ND & ND & ND & ND & 7 & 4 & 3.8 \\
\hline $310 \ldots \ldots \ldots \ldots \ldots \ldots$ & 332 & 20.3 & .93 & 78.25 & 40 & .11 & ND & 20 & 20 & ND & 18 & 18 & 36 \\
\hline $350 \ldots \ldots \ldots \ldots \ldots \ldots$ & 359 & 19.7 & .93 & 78.40 & .68 & .22 & 200 & 40 & 40 & ND & 25 & 36 & 3.1 \\
\hline
\end{tabular}

Table 2-9.-Gas analyses results for samples collected above $25.4-\mathrm{mm}$ layers of $50-\mathrm{gal} / \mathrm{ton}$ oil shale dust

\begin{tabular}{|c|c|c|c|c|c|c|c|c|c|c|}
\hline \multirow{2}{*}{$\begin{array}{c}\text { Hotplate surface } \\
\text { temperature. } \\
{ }^{\circ} \mathrm{C}\end{array}$} & \multirow{2}{*}{$\begin{array}{c}\text { Layer temperature } \\
\text { at time of } \\
\text { sampling, }{ }^{\prime} \mathrm{C}\end{array}$} & \multicolumn{8}{|c|}{ Coricentration, vol pct } & \multirow{2}{*}{$\begin{array}{c}\mathrm{CO}_{2}-\mathrm{CO} \\
\text { ratio }\end{array}$} \\
\hline & & $\mathrm{O}_{2}$ & $\mathrm{Ar}$ & $\mathrm{N}_{2}$ & $\mathrm{COO}_{2}$ & $\mathrm{CO}$ & $\mathrm{CH}_{4}$ & $\mathrm{C}_{2} \mathrm{H}_{6}$ & $\mathrm{C}_{2} \mathrm{H}_{4}$ & \\
\hline $250 \ldots \ldots \ldots \ldots \ldots \ldots \ldots$ & 390 & 20.0 & 0.93 & 78.27 & 0.69 & 0.11 & 0.02 & 0.006 & 0.003 & 6.3 \\
\hline \multirow{2}{*}{$260 \ldots \ldots \ldots \ldots \ldots \ldots \ldots$} & 280 & 17.7 & .94 & 78.56 & 2.20 & .46 & .08 & .023 & .012 & 4.8 \\
\hline & 380 & 19.5 & .93 & 78.31 & 1.06 & .15 & .03 & .008 & .005 & 7.1 \\
\hline \multirow[t]{2}{*}{$380 \ldots \ldots \ldots \ldots \ldots \ldots$} & 300 & 19.6 & .93 & 78.38 & .84 & .21 & .01 & .009 & .006 & 4.0 \\
\hline & 380 & 20.6 & .93 & 78.21 & .22 & .03 & ND & .003 & .001 & 7.3 \\
\hline
\end{tabular}

ND Not detected.

At geometric center.

Table 2-10.-Gas analyses results for samples collected above $25.4-\mathrm{mm}$ layers of Pittsburgh coal dust

\begin{tabular}{|c|c|c|c|c|c|c|c|c|c|}
\hline \multirow{2}{*}{$\begin{array}{c}\text { Hotplate surface } \\
\text { temperature, } \\
{ }^{\circ} \mathrm{C}\end{array}$} & \multirow{2}{*}{$\begin{array}{c}\text { Layer temperature } \\
\text { at time of } \\
\text { sampling. }{ }^{1}{ }^{\circ} \mathrm{C} \\
\end{array}$} & \multicolumn{7}{|c|}{ Concentration, vol pct } & \multirow{2}{*}{$\underset{\text { ratio }}{\mathrm{CO}_{2}-\mathrm{CO}}$} \\
\hline & & $\mathrm{O}_{2}$ & Ar & $N_{2}$ & $\mathrm{CO}_{i^{\prime}}$ & $\mathrm{CO}$ & $\mathrm{CH}_{4}$ & $\mathrm{C}_{2} \mathrm{H}_{6}$ & \\
\hline \multirow[t]{2}{*}{$210 \ldots \ldots \ldots \ldots \ldots \ldots$} & 290 & 20.0 & 0.93 & 78.40 & 0.43 & 0.23 & 0.02 & 0.002 & 1.9 \\
\hline & 406 & 18.3 & .93 & 78.23 & 1.40 & .90 & .17 & .044 & 1.6 \\
\hline \multirow[t]{2}{*}{$380 \ldots \ldots \ldots \ldots \ldots \ldots$} & 413 & 19.8 & .93 & 78.24 & .60 & 37 & .04 & .014 & 1.6 \\
\hline & 429 & 19.7 & 93 & 78.41 & 56 & .35 & .04 & .011 & 1.6 \\
\hline
\end{tabular}

${ }^{1}$ At qeometric center. 
The results in table 2-8 show increased amounts of $\mathrm{CO}_{2}$ and $\mathrm{CO}$ combustion products with increasing layer temperature. $\mathrm{CO}_{2}$ is more abundant than $\mathrm{CO}$ in the three samples. The hydrocarbons are present in trace quantities in all the samples, but results suggest a trend for increasing amounts at higher temperatures. Higher hydrocarbons, up to $C_{5}$, were also detected in trace quantities, but are not reported. No attempt was made to detect hydrocarbons above $C_{5}$ or to analyze condensed products.

The compositions of gas samples collected above 25.4 $\mathrm{mm}$ layers of 50-gal ton oil shale are presented in table 2-9. For these thicker lavers, peak amounts of gases were found, in general, when the layer temperature was about $300^{\circ} \mathrm{C}$. By about $300^{\circ} \mathrm{C}$, a black crust formed on top of all the layers in these tests. This crust may have reduced the flow of air into the lavers and flow of products out of the lavers. The $\mathrm{CO}_{2}$-to- $\mathrm{CO}$ ratios are higher for the rich oil shale than for the lean oil shale. The effect of laver thickness on this ratio was not evaluated in this test program, but could also be a factor.

It is of interest to compare the above results with values found for gas samples collected above $25.4-\mathrm{mm}$-thick layers of coal (table 2-10). Slightly larger amounts of $\mathrm{CH}_{4}$ and $\mathrm{C}_{2} \mathrm{H}_{6}$ and of the other hydrocarbons (which are not shown here) were found, but the differences were small. The main difference is seen in the ratio of $\mathrm{CO}_{2}$ to $\mathrm{CO}$, which is much smaller owing to the larger amounts of $\mathrm{CO}$ emanating from the coal laver.

In general, the only combustion gases found in significant amounts are $\mathrm{CO}_{2}$ and $\mathrm{CO}$. The hydrocarbons are present in trace amounts. In all cases, $\mathrm{CO}_{2}$ is present in larger amounts than $\left(\mathrm{C}^{\circ}\right.$, and the ratio of $\mathrm{CO}_{2}$ to $\mathrm{CO}$ is larger for the oil shate than for the coal.

Finally, gas samples were collected during the laver tests conducted in the flammable atmosphere. Results of analyses of some of these samples are shown in table 2-11. In these tests, confinement alfected the gas composition results. The accumulated combustion products reduced the oxygen concentration inside the enclosure. Therefore, it was necessary to determine whether there was sufficient oxygen for the combustible gases in the enclosure to propagate a flame. Calculations showed that sufficient oxygen was available to sustain a flame or explosion, if a suitable ignition source had been present. This was verified by igniting the mixture in the enclosure with a lighted match.

\section{SPRINKLE TESTS}

Dust slowly settling on hot sufaces will initially form small, uneven island of very thin layers. Sprinkle tests were conducted in order to simulate this initial stage of layer formation. In these tests, the fine dusts were sprinkled from a spatula onto the heated surface. The deposits that formed were on the order of 1 to $2 \mathrm{~mm}$ in thickness. From the trends found in the layer tests, it was clear that surface temperatures in excess of $300^{\circ}$ C would be required for ignition of very thin accumulations. The ignition criterion used in the sprinkle tests was the formation of glowing particles, partly because measurement of temperatures was not practical. Nonglowing particles, or piles, also pyrolyzed, but the heat generated was not sufficient to overcome heat loss, and as a result oxidation of the formed char with its concurrent glow did not occur.

Glowing occurred when the char oxidized, and in most cases it happened after the formation of small, rounded globules by the oil shale particles. This agglomeration of the small particles is believed to be due to the wetting of the particles by the oil that is generated by reacting kerogen. The lowest surface temperature at which glowing was observed when the 50-gal/ton oil shale dust was sprinkled on the heated surface was $330^{\circ} \mathrm{C}$. Higher temperatures were required for the leaner oil shales. The 33-gal/ton oil shale did glow at about $340^{\circ} \mathrm{C}$ and the $20-\mathrm{gal} / \mathrm{ton}$ shale at $380^{\circ} \mathrm{C}$, but the glow was not as bright and not as many particles reacted all the way to the glowing stage. At these high surface temperatures, reaction of the dust was almost instantaneous. Glowing particles were not observed when fine coal dust was sprinkled on surfaces close to $400^{\circ} \mathrm{C}$ in temperature.

The surface temperatures at which the particles glowed and the estimated layer thicknesses were used to extend the curves of figure 2-11, representing minimum hot-surface ignition temperatures as a function of layer thickness. The resultant curves, shown in figure $2-14$, can be used cautiously for interpolation, keeping in mind that the ignition criterion for the very thin layers differs from that for the thicker layers.

\section{TESTS IN FLAMMABLE ATMOSPHERES}

The tests were conducted with 25.4-mm-thick layers of fine 50-gal/ton oil shale and coal dusts at surface temperatures of about $380^{\circ} \mathrm{C}$. With the onset of ignition in the layer, a flow of air of about $11 \mathrm{~L} / \mathrm{min}$ was first directed downward over the layer to enhance the development of substantial areas of glowing particles. When the air in the enclosure was then replaced with a flammable methane mixture, glowing was dimmed and then suppressed. Replacement of the flammable atmosphere with a fresh flow of air renewed the glow. In no case was the flammable atmosphere ignited by the layers.

It is important to note that the reacting layers themselves emitted gases and vapors, and thereby changed the composition of the atmosphere in the enclosure. To ascertain the presence of a flammable atmosphere, gas samples were taken inside the enclosure and analyzed by gas chromatography. Results of the analyses, displayed in table 2-11, showed the presence of small amounts of $(\mathrm{O}), \mathrm{H}_{2}$, and $\left(\mathrm{O} \mathrm{O}_{2}\right.$. Methods exist for calculating the flammability of any mixture of combustible

Table 2-11.-Gas analyses results for samples collected above heated layers of 50 -gal/ton oil shale and Pittsburgh coal inside flammable gas enclosure

\begin{tabular}{|c|c|c|c|c|c|c|c|c|c|c|c|c|c|}
\hline \multirow{3}{*}{$\begin{array}{c}\text { Dusl } \\
\text { sample }\end{array}$} & \multirow{3}{*}{$\begin{array}{c}\text { Layer } \\
\text { thickness. } \\
\mathrm{mm}\end{array}$} & \multirow{3}{*}{$\begin{array}{c}\text { Hotplate } \\
\text { surface } \\
\text { temperature. } \\
{ }^{\circ} \mathrm{C}\end{array}$} & \multirow{3}{*}{$\begin{array}{l}\text { Conditions during } \\
\text { sampling }\end{array}$} & \multicolumn{9}{|c|}{ Concentration } & \multirow{3}{*}{$\begin{array}{c}\mathrm{CO}_{2} \cdot \mathrm{CO} \\
\text { ratio }\end{array}$} \\
\hline & & & & \multicolumn{7}{|c|}{ vol pct } & \multicolumn{2}{|c|}{ ppm } & \\
\hline & & & & $\mathrm{O}$ & $\mathrm{Ar}$ & $N_{2}$ & $\mathrm{CO}_{2}$ & $\mathrm{CO}$ & $\mathrm{CH}_{13}$ & $\mathrm{H}_{2}$ & $\mathrm{C}_{2}, \mathrm{H}_{\mathrm{t}}$ & $\mathrm{C}_{4}, \mathrm{H}_{4}$ & \\
\hline Oll shale $50 . \mathrm{gal} / \mathrm{ton}$ & 127 & 360 & Smoke and flammable atmosphere & 16.2 & 0.86 & 726 & 23 & 033 & 7.5 & 0.18 & 575 & 320 & 7.0 \\
\hline \multirow[t]{2}{*}{ Do } & 25.4 & 365 & 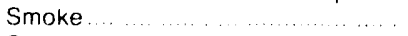 & 18.7 & 94 & 78.9 & 1.1 & 29 & 1 & ND & 100 & 130 & 38 \\
\hline & & & Smoke and flammable atmosphere & 167 & 86 & 722 & 1.6 & 32 & 8.3 & ND & 375 & 90 & 5.0 \\
\hline \multirow[t]{3}{*}{ Pittsburgh coa! } & 254 & 360 & 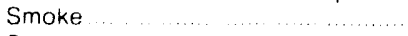 & 177 & 93 & 78.0 & 17 & 110 & 4 & 10 & 515 & 120 & 1.5 \\
\hline & & & Smoke and flammable atmosphere & 156 & 86 & 723 & 20 & 195 & 6.9 & 35 & 665 & 130 & 1.0 \\
\hline & & & & 14.3 & 85 & 711 & 24 & 2.20 & 85 & 60 & 885 & 180 & 1.1 \\
\hline
\end{tabular}

ND Not detected 


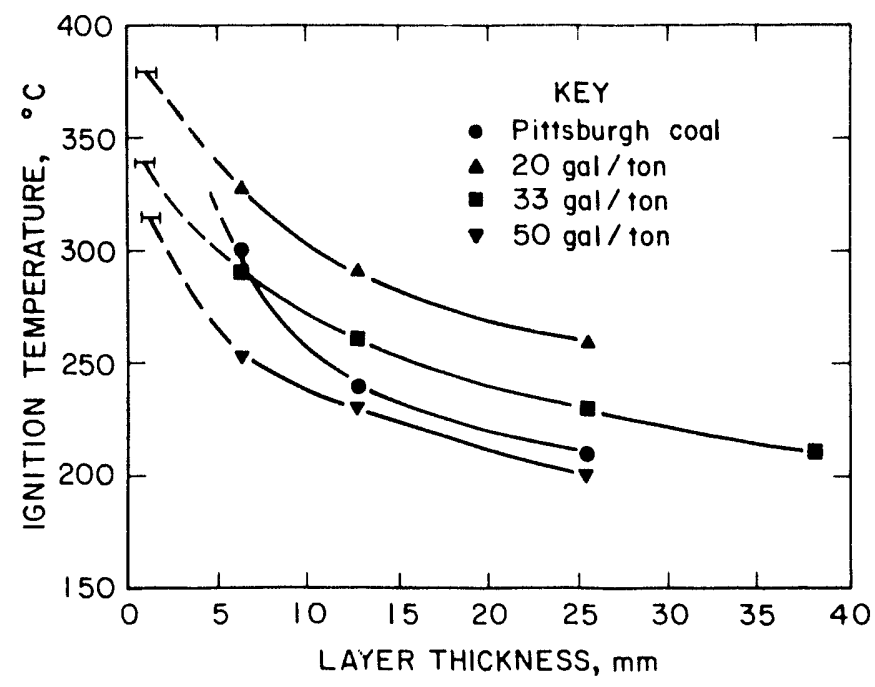

Figure 2-14.-Minimum hotplate surface ignition temperatures for fine oil shale and Pittsburgh coal dusts as a function of layer thickness, including values from sprinkle tests.

and inert gases (13). These methods were applied to the atmospheres inside the enclosure, and they were determined to be flammable.

In addition to the layer tests, sprinkle tests with fine coal and 50-gal/ton oil shale dusts were also conducted in a flammable atmosphere. Ignition of the gas mixture did not occur at any time. The flammable atmospheres were readily ignited by a lighted match thrown into the enclosure.

\section{HIGH-TEMPERATURE HOTPLATE $\left(>400^{\circ} \mathrm{C}\right)$}

The high-temperature hotplate consisted of a thick stainless steel plate atop a circular heating coil. Local variations in the temperature across the plate surface were large and followed the pattern of the coil.

Both the $50 \mathrm{-gal} / \mathrm{ton}$ oil shale and coal dusts reacted immediately upon being placed on the hottest portions of the plate, which were easily discerned by a dull red color. The surface temperatures were at least $470^{\circ} \mathrm{C}$, and probably higher. Large amounts of volatiles and yellow-brown fumes were emitted. Temperatures measured inside thin layers of oil shale were on the order of $570^{\circ} \mathrm{C}$, and red glowing particles were evident. Red glow inside thicker layers was also observed.

When coal was placed on the hot surface, glowing particles formed. A mixture of fine and coarse coal particles was tested, and crackling sounds were heard. The coarser particles disintegrated and at times even flew apart; these events were accompanied by tiny sparks.

The only time flaming combustion occurred was when a piece or particle of either oil shale or coal came in direct contact with the bright red heating coil $\left(>750^{\circ} \mathrm{C}\right)$. The flame flashed back to the pile, which was located on the central portion of the stainless steel plate, about $6 \mathrm{~cm}$ away:

\section{DISCUSSION OF RESULTS}

\section{MINIMUM HOT-SURFACE IGNITION TEMPERATURES}

The hotplate minimum ignition temperatures were very reproducible in the tests with the oil shale and the coal samples. Small variations in the packing densities and in ambient conditions, such as humidity and temperature, did not noticeably affect the results. Perhaps the difference of $10^{\circ} \mathrm{C}$ between ignition and nonignition is a sufficient margin to compensate for such effects.

The minimum hot-surface ignition temperatures decrease in an orderly fashion with increasing oil shale richness for the fine oil shale dusts with similar particle size distributions. The greater amount of kerogen in the richer oil shales and the larger amount of volatiles released by them at a lower temperature during decomposition combine to generate more heat during air oxidation. Lee and Sohn (14) investigated the ignition characteristics of various grades of Green River oil shale and determined that the energy required for ignition decreased with increasing shale grade. In the hotplate tests, ignition energy is represented by the hotplate surface temperature, but it cannot be calculated accurately because of the unknown amounts of heat loss to the surroundings.

The other systematic change in the minimum hot-surface ignition temperatures of all the tested dusts related to layer thickness. The minimum hot-surface ignition temperatures decreased with increasing layer thick ness. The ignition process on the hotplate is very sensitive to heat loss, and any provision that decreases heat loss aids the process. The thicker layers reduce heat loss from the layer, and the result is a lower ignition temperature.
It is always helpful to compare experimental results with values found by other researchers. However, published experimental results for hotplate tests of coal and oil shale are scarce, and the ones available were not obtained by exactly the same test procedures as were used in this study. Ignition criteria also vary from one publication to another.

For Pittsburgh Seam coal dust $(80$ pct through 200 mesh), the minimum ignition temperature, as determined by the modified Godbert-Greenwald furnace test, is $170^{\circ} \mathrm{C}(15)$. When the same coal was tested in a hotplate test, in which the layer dimensions were $1 \mathrm{in}$. in diameter and $1 / 2 \mathrm{in}$. in height and the confining ring was made from a 40-mesh screen, the same temperature of $170^{\circ} \mathrm{C}$ was obtained (/2). This is somewhat surprising since the small layer dimensions and nonisothermal conditions in the latter test are conducive to heat loss, and a higher ignition temperature would have been expected. In the modified Godbert-Greenwald furnace, the minimum ignition temperature of the Pittsburgh Seam coal from the present test series was determined to be $175^{\circ} C^{\circ}$.

Hotplate tests with oil shale dusts were conducted by the Tosco Corp. under Bureau contract. In these tests, a 35gal/ton oil shale (minus 200 ) plus 325 -mesh fraction) was tested on a hotplate whose surface cemperature was set at $20\left(0^{\circ}\right.$, $230^{\circ}$, and $260^{\circ} C^{\circ}$. Only the var. is that evolved during the test at $260^{\circ} \mathrm{C}$ ignited when a pilot flame was passed over the dust (10). A lew samples of 10-, 20-, and 30-gal/ton oil shale dusts were also tested in the modified (iodbert-(ireenwald furnace, and a nominal ignition temperature of $200^{\circ}$ ( was reported (10). However, the test data and ignition criteriat are not presented in sufficient detail to determine the minimum ignition temperatures of the various samples. When a 5() -gal/ton 
oil hale was tested in the modified (iodbert-Greenwald furnace, a misnimum ignition temperature of $180^{\circ}$ (' was reported (15): the equivalent minimum ignition temperature of the s()-gal ton oil shate from the present test series was determined to be $175^{\circ}$ ( )

As mentioned in the introduction to part 2, hotplate tests of coal and oil shale were also conducted by the Bureau (9). Pulserized Pittsburgh Seam coal and three oil shales (19-, 25-, and 48 -gall ton; 95 pet through 200 mesh), were tested. For unconfined, 25.4-mm-thich lavers of Pittsburgh coal dust, the minimum igmtion temperature was $210^{\circ}$ ('. A 50 -mm-thick laver of the same coal ignited at $2(\%)^{\circ}$ ( alter $400 \mathrm{~min}$. of continuous heating. The minimum hot-surface ignition temperature for $5(1-\mathrm{mm}$-thick layers of the three oil shales were $30(1)^{\circ}, 24()^{\circ}$, and $200^{\circ}($, respectively. The results for the 25.4-mm-thick coal laver are the sam: as were found in this study. The results for the oil shales show the same trend as in this study but cannot be directly compared because thicker layers were used and the ignition criteria and test procedures were different.

In hotplate test results mentioned earlier (10), for a 35-gal ton oil thale, the minimum hot-surface ignition temperature was not given. Instead, tests were conducted at barious hotplate surface temperatures, and the emitted vapors were tested for ignitability by a pilot flame. A similar effort was made in this study to determine the hotplate semperature at which evolved gases would be ignited by a flame. Altempts 10 ignite the vapors and or smoke emanating from layers of the 5()-gal ton oil shale with a pilot flame were seldom suceessful. When the laver temperature was at least $3(x)^{\circ}\left({ }^{\circ}\right.$, the thame from a lighted match held above the layer flashed back to the layer, but was not sustained. The only time ignition of vapors by a lighted match was repeatedly successful was when the 50 -gal/ton oil shale, or coal dust, was heated on the high-temperature hotplate at surface emperatures above $470^{\circ} \mathrm{C}$. Also, when particles of the oil shale or coal fell from the stainless steel plate onto the bare coil (surface temperature $>750^{\circ}$ (), they ignited instantaneously and the flame flashed back to the nearby layers. Thus, lammable gas mixtures were formed only when volatiles were generated at at high rate and in large quantities by rich oil shale in contact with a high-lemperature surface.

Plots of the minimum sot-surface ignition temperature versus layer thickness, as shown in figure 2-14, are not linear and thus are not easily extrapolated. However, when the logarithm of layer thicknesses were plotled as a function of the reciprocal values of the ignition temperatures in kelvins, as suggested in the hotplate test procedure and as shown in figure 2-15, straight lines resulted for the three oil shate dusts but not for the coal dust. A comprehensive theoretical analysis of hotplate test results, by Bowes and Townshend (16), correlates the logarithm of the function $\delta \mathrm{r}^{2}, \mathrm{r}^{2}$ with the reciprocal of the ignition temperature. The function, in which $r$ is half the layer thickness, $T$ is the minimum ignition temperature, and $\delta$ is a complex combination of various parameters, is proportional to the rate of heat evolution per unit volume of reacting mass. The slopes of the resultant straight lines yield activation energy values. Several assumptions and additional data are required

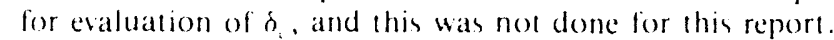

The plots for the 20)- and 50-gal/ton oil shales in figure 2-15 are parallel, while the slope of the line for the 33-gal/ton oil shale more closely resembles the slope of the upper portion of the coal curve. As stated earlier, the 33-gal/ton oil shale originated from a different location than the two other oil shates and probably comains different proportions of the compounds constituting the inorganic matrix, or possibly even other minerals. The reason for the nonlinear behavior of the coal is not known.

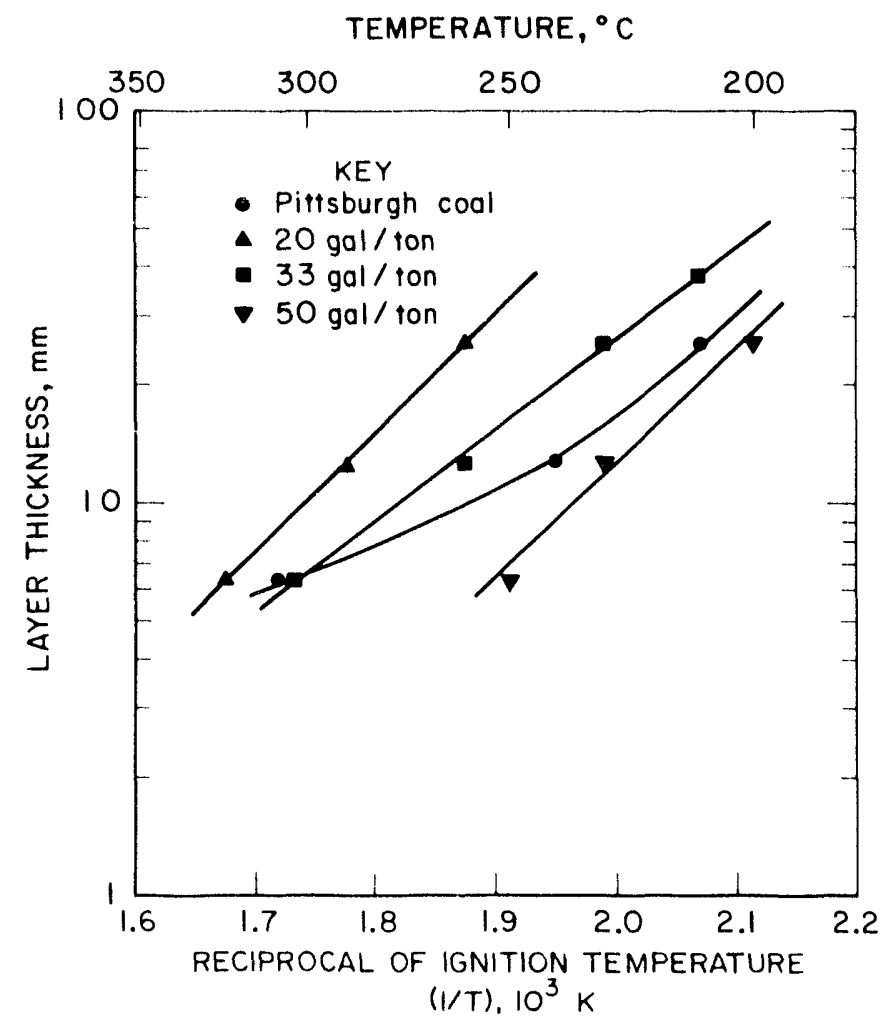

Figure 2-15.-Semilog plots of layer thickness versus reciprocal of minimum ignition temperature (in kelvins) for fine oil shale and Pittsburgh coal dusts.

Long-duration hotplate tests, in which the hotplate surlace temperature was initially lower than the minimum ignition temperature but then was slowly raised to temperatures that were much higher than the minimum ignition temperature, failed to ignite the samples. Whatever the events that take place when the oil shale dusts undergo prolonged heating at temperatures lower than their minimum ignition temperatures, snmehow they become more resistant to additional, and more energetic, thermal stimuli. These results indicate an increase in relative safety for dust layers accumulating slowly over long periods of time on hot surfaces.

\section{MAXIMUM TEMPERATURES ATTAINED INSIDE LAYERS}

With a few exceptions, the maximum temperatures attained inside the layers of oil shale and coal when they were heated at their respective minimum hot-surface ignition temperatures were about $4(0) \pm 20^{\circ}\left({ }^{\circ}\right.$. Higher temperatures were found in the 12.7-and 25.4-mm-thick layers of the 33-gal/ton oil shale $\left(436^{\circ}\right.$ and $482^{\circ} \mathrm{C}$, respectively). The highest temperature was $560^{\circ}$ (', for the 25.4 -mm-hick layer of fine coal dust.

The maximum rise in layer temperature above the minimum hot-surface ignition temperature ( $\Delta \Gamma \max$ ), for the various samples, is shown in table $2-12$. The maximum rise in temperature, in general, increased with increasing layer thickness for the samples, allhough the increase was less pronounced for the 2() - and $5($-gal/10n shale dusts. This increase is due to the reduction in heat loss; the thicker layers in essence act as incu!!a!ors. The maxim!n!m rise in temperature increased 
Table 2-12. - Maximum rise in temperature $(\Delta T \text { max })^{\prime}$ inside layers heated at their respective minimum hot-surface ignition temperatures, degrees Celsius

\begin{tabular}{|c|c|c|c|}
\hline Dust sample & $6.4 \mathrm{~mm}$ & $12.7 \mathrm{~mm}$ & $25.4 \mathrm{~mm}$ \\
\hline \multicolumn{4}{|l|}{ Oil shale } \\
\hline 20 -gal/ton. & 100 & 121 & 123 \\
\hline 33-gal!ton.. & 130 & 176 & 252 \\
\hline 50-gal/ton ..... & 169 & 167 & 192 \\
\hline Pittsburgh coal & 35 & 146 & 350 \\
\hline
\end{tabular}

'At geometric center.

with increasing grade for the thin layers of the oil shales. The same cannot be said for the 12.7- and $25.4-\mathrm{mm}$ layers of oil shales, mainly because the values for the 33-gal/ton oil shale are not in line with the values for the other two oil shales. Maximum increases in temperature irsside layers of some of the samples that were tested at higher surface temperatures than the minimum ignition temperatures were essentially the same as those in iable 2-12.

To achieve higher temperatures in reacting solid fuels, contributions from vapor phase reactions are important. Such vapor phase reactions, which in general occur as flames, were not observed. The volatiles generated by the reacting layers were either not present in sufficient quantities to be in the flammable range, or else the temperature at the surface of the layer was lower than that required for ignition of the flammable mixture. Similar gas mixtures are generated by other pyrolyzing fucls, such as cellulose. Yoshizawa and Kubota determined the temperature of self-ignition of such mixtures of $\mathrm{CO}, \mathrm{CH}_{4}, \mathrm{C}_{2} \mathrm{H}_{4}, \mathrm{C}_{2} \mathrm{H}_{6}$, and $\left.\mathrm{C}^{\circ}\right)_{2}$ in air to be $540^{\circ} \mathrm{C}(17)$; ignition occurred at or near the rich flammable limit. The 33-gal ton oil shale and the Pittsburgh Seam coal did generate high temperatures when heated in thick layers, but the combination of the required flammable gas enneentration and layer surface temperature for initiating flaming combustion was evidently not attained.

\section{EFFECT OF LAYER CONFINEMENT}

When layers are not confined by a metal ring, diffusion of air into the sides of the sample increases, but at the same time heat losses also increase. In the few tests that were done, the same minimum ignition temperature was found for both the confined and uncontined layers. These results suggest that a balance, or equilibrium, was established, in which the effects of diffusion and heat loss cancelled each other. However, it should be noted that slightly higher maximum temperatures were attained inside the unconfined layers. A more detailed examination of this parameter would be worthwhile, especially since most dust accumulations on hot surfaces are not confined.

\section{PARTICLE SIZE EFFECTS}

The minimum hot-surface ignition temperatures for the coarse 33-gal/ton shale and coal samples were greater than $400^{\circ}($. The exact values were not determined because they were greater than the highest temperature the hotplate could attain. In comparison, the minimum hot-surface ignition temperatures for the 12.7 -mm-thick layers of the line 33 gal/ton shale and coal dust were $260^{\circ}$ and $240^{\circ}$ (', respectively. Several factors contributed to this significant difference. The coarse samples had a wider particle size distribution than the fine samples. Consequently, a greater layer density resulted, capable of restricting airflow through the layer and thereby minimizing exothermic reactions. The contributions from exothermic surface oxidation reactions are reduced for layers of coarse particles that have smaller overall surfice areas. More time is required to evenly heat the coarse particles throughout, and a slower heating rate results. Finally, and most importantly, the decomposition products that form inside the larger particles have a longer diffusion path and, consequently, more time to undergo further decomposition. This leads to coking of the gas and oil products. As a result, the amou, $t$ of thermal feedback from vapor oxidation is reduced.

Oil shale pyrolysis and combustion and oil shate retorting have been extensively studied. The many parameters evaluated include particle size and heating rate. Although layer lests were not utilized in these studies, the results regarding particle size effects are valid for comparison with the results of the layer tests. Galan and Smith (18) used thermogravimetric analysis to evaluate the effects of transport processes on the decomposition of small samples of Colorado oil shate and found three modes to be important. These were interparticle, intraparticle, and particle-to-fluid transport phenomena. Decomposition rate, measured as weight loss, decreased when particle size was greater than $0.4 \mathrm{~mm}$. Galan and Smith conducted their tests in a nitrogen atmosphere; thus, oxidative decomposition was not a factor.

Campbell also studied the effect of particle size on oil degradation inside shale particles (19). He attributed coke formation within the particles to slow heating rate, rather than to particle size. A Colorado oil shale dust with particles smaller than $800 \mu \mathrm{m}$ was used in the tests, in cither nitrogen or self-generated atmospheres. Essentially, the results agree with the layer test results, because larger particles are heated at slower rates.

Suuberg (20) studied the pyrolysis of bituminous coal that $\checkmark$ as heated in an atmosphere of helium at a fast rate. Particle sizes tested ranged from 74 to $1,000 \mu \mathrm{m}$. Less tar and more char formed when particle size was increased. He also suggest mass transport effects and secondary reactions within or on the particles as an explanation of the results.

Nagy and Verakis (12) present data obtained in the Codbert-Creenwald furnace test that show increases in the minimum ignition temperatures of coal dust layers with increasing particle size. The ignition temperatures reported for two coal dusts, one a 20-pet and the other a 75-pet minus $20\left(\right.$ )-mesh coal, were $210^{\circ}$ and $170^{\circ} \mathrm{C}$, respectively. These dusts are similar in size to the coarse and fine coal dusts utilized in the present study and for which the corresponding minimum hot-surface ignition temperatures were determined to be $>380^{\circ}$ and $240^{\circ} \mathrm{C}$, respectively, for a $12.7-\mathrm{mm}$ layer. Although the same trend is seen, the results are not directly comparable to those of this study because of the different test methods employed.

Palmer and Tonkin measured ignition temperatures of conical dust layers on hot surfaces $(2 /)$. For a cork dust, the ignition temperature increased with increasing particle size. Although they do not report the effect of particle size on the minimum ignition temperature of coal dust, the minimum ignition temperature found by them for a 25 -mm-thick coal dust layer consisting of particles $<0.063 \mathrm{~mm}$ in diameter (minus 230 mesh) was $210^{\circ}$ (. This value is identical to that found in the present study for fine Pittsburgh coal of approximately the same particle size and layer thickness.

The importance of these results lies in the fact that much higher hot-surface temperatures are needed to intiate reactions and ignite a layer comprised of larger particles or of a mixture of small and large particles. Such layers can tolerate higher surface temperatures without igniting. 


\section{WEIGHT LOSS}

Kerogen, the fuel-bearing portion of oil shale, constitutes a relatively small part of the oil shale by either weight or volume. The major portion of the oil shale is a matrix of inorganic compounds. In the range of temperatures encountered in the layer tests, the inorganic portions of the shales do not undergo any significant decomposition, and the observed weight losses reflect solely the decomposition of kerogen and the evaporation of the small amount of moisture present in the oil shale. Results of weight losses show that the 50 -gal/ton oil shale underwent appreciable decomposition (on the order of 50 wt pet of kerogen) at a hotplate temperature of $230^{\circ}$ to $250^{\circ} \mathrm{C}$, while a surface temperature of $290^{\circ} \mathrm{C}$ was refuired for a similar degree of decomposition of the 20 -gal/ton oil shale. These data support the previous results of lower ignition temperatures for higher oil shale grades. Higher temperatures, around $350^{\circ} \mathrm{C}$, were required for a more complete kerogen decomposition of both oil shales.

Not only hot-surface temperatures but also layer thickness, exposure time on the hot surface at any specific temperature or temperature range, and packing density of the layer affect the extent of weight loss. Although packing densities were similar for most of the layers of any one sample, they still varied from test to test. Variations in density were greater for the thin lavers. Avalability of oxygen to the reacting layer and heat loss from the layer depend strongly on layer density, and they in turn influence the maximum temperatures attained inside the lavers and the resultant weight losses. The results in tables 2-6 and 2-7 reflect the combined effects of the various parameters on weight losses in the hotplate tests.

In addition to the decomposition of kerogen, oxidation and pyrolysis reactions of kerogen and its decomposition products that form volatiles also contribute to the weight loss. These reactions drive the smolder wave through the reacting layer. In these hotplate layer tests, the hot surface provides an energy flow in a direction that opposes the flow of oxygen. The air diffuses into the laver mostly from the top and, in the process, actually reverses part of the energy flow. This mode of reaction, known as reverse smolder, depends on and is limited by oxygen awailability and heat transfer, which are interdependent. It may also interfere with the upward flow of combustion products.

In many of the hotplate tests in which the oil shale layers ignited, only chars formed, and even then, only a part of the layer converted to char. The additional oxygen and energy needed for the oxidation of the chatr and formation of ash was apparently not atailable.

When the coarse 33-gal ton oil shale laver was heated at a high hot-surface temperature $\left(380^{\circ} \mathrm{C}\right)$, it underwent chemical changes that were obvious to the eye, yet both weight loss and temperature rise were minimal. The reason is mainly coking of the generated volatiles within the larger particles. Minimal weight ioss also occurred when lavers of coarse coal were heated in a similar manner.

\section{GAS SAMPLES}

All the gas amples collected above the heated lavers at various hot-surface temperatures and at different periods during the tests did not contain large quantities of flammable gases. Dilution during sampling was partly responsible for these results. The only two gases found in any significant concentrations were $(\mathrm{O})$, and $\mathrm{CO}$. $(\mathrm{C})$, was present in larger quantities, as seen in tables 2-8 10 2-10. $(0$, is a direct decomposition product of the oil shale and the coal; it maly also be formed by oxidation of the evolved $\mathrm{CO}$ as it diffuses through the layer. The temperature of the evolved gases as they effuse from the layer is probably too low for oxidation in the ambient air.

Samples of gas emanating from cores of spent oil shale undergoing char combustion were collected by Manor (22). When the cor was heated at $483^{\circ} \mathrm{C}$, the ratio of $\left.\mathrm{CO}\right)_{2}$ to $\mathrm{CO}$ in the gas sample was about 4 . The ratio is dependent on the temperature of the char and increases at higher temperatures. These results are very similar to those found for samples collected above the oil shale layers and suggest that the char that formed on the surface of many of the oil shale layers as well as inside some of the layers generated combustion gases. Temperatures of about $6(0)^{\circ} \mathrm{C}$ or more, depending on char reactivity, produced self-sustaining reactions between the char and air in Manor's tests. This may be the temperature of the glowing particles observed in some of the layer tests.

The gas samples that were collected above the reacting coal layers contained relatively larger amounts of $\mathrm{CO}$ than samples collected above the oil shale layers. Only traces of flammable hydrocarbons were detected in any of the gas samples. In general, $\mathrm{CH}_{4}$ was present in larger amounts than were the higher hydrocarbons in gas samples taken above the coal. This was not always the case in samples from the oil shales.

Even considering the fact that the gas samples were diluted with air during sampling, none of the flammable gases were found in quantities anywhere near their lower flammability limits. The limits in air are the following:

\begin{tabular}{|c|c|}
\hline Gas & $\begin{array}{c}\text { Iower flammability limit, } \\
\text { vol pot }\end{array}$ \\
\hline 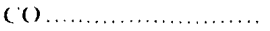 & 12.5 \\
\hline$\left(\mathrm{H}_{4}, \ldots \ldots \ldots \ldots \ldots \ldots \ldots \ldots \ldots\right.$ & 5.0 \\
\hline$C_{2} H_{t}, \ldots \ldots \ldots \ldots \ldots \ldots$ & 3.1 \\
\hline$\left({ }_{2} H_{4} \ldots \ldots \ldots \ldots \ldots \ldots \ldots\right.$ & 2.7 \\
\hline
\end{tabular}

The concentrations of these gases in the collected samples were much smaller. Hydrocarbons such as $\mathrm{C}_{2} \mathrm{H}_{4}$ and $\mathrm{C}_{2} \mathrm{H}_{\text {, sensitize }}$ mixtures of $\mathrm{CO}$ and $\mathrm{CH}_{4}$ and can lower their ignition temperatures. However, the gaseous mixture has to be within the flammable limit to ignite.

In view of the above, the absence of flaming during the tests may be explained. The first requisite for combustion is the formation of a flammable mixture. This, however, is not sufficient to ensure the autoignition of the mixture. A critical surface temperature-the ignition source-is needed as well. The highest layer surface temperatures in the layer tests were about $370^{\circ} \mathrm{C}$. They were recorded for $25.4-\mathrm{mm}$-thick layers of 50-gal/ton oil shale and of coal that were heated on very hot surfaces $\left(-380^{\circ} \mathrm{C}\right)$. The maximum layer surface temperatures in most of the other tests in which ignition occurred were lower, even as low as $111^{\circ} \mathrm{C}$. These lower temperatures are a good indication that gas flux at the surface was minimal. They also point to the lack of energy input or feedback from gas phase reactions near the surface into the solid. Without such interactions, flaming combustion cannot occur. The small amounts of flammable gases generated by the oil shale are due to the relatively slow smolder-type reactions that are at least an order of magnitude slower than flame reactions.

\section{SPRINKLE TESTS}

As was demonstrated in the layer tests, the hot-surface ignition temperatures increased with decreasing layer thickness. Sprinkle tests provide a means for evaluating the behavior of very thin layers or smatl piles of dust on hot surfaces. 
The ignition criterion chosen for the tests was the formation of glowing particles.

When particles of fine oil shale dust were sprinkled on a sufficiently high-temperature surface, they reacted instantaneously, emitting smoke and volatiles. (ilowing particles were seen when the char on the surfaces of the particles reacted with air and formed $\mathrm{CO}_{2}$ and/or $\mathrm{CO}$, leaving behind a residue of ash.

The glowing behavior was not seen with single particles. It was observed when a few particles combined together to form a larger mass, thereby decreasing heat loss. Hot-surface temperatures in excess of $340^{\circ} \mathrm{C}$ were required for glowing particle formation with 50-gal/ton shale dust, and higher surface temperatures were required for leaner oil shales. The number of glowing particles and degree of brightness increased with increasing grade of oil shale. Exudation of shale oil may be a contributing factor in the agglomeration of the fine oil shale particles. In sprinkle tests of coal dust, glowing particles were not observed at hot-surface temperatures close to $400^{\circ} \mathrm{C}$.

\section{TESTS IN FLAMMABLE ATMOSPHERES}

The main purpose of the tests in the flammable atmospheres was to determine if the temperatures attained by the hot dust layers were sulficiently high to ignite methane-air flammable mixtures. The tests were conducted so as to create favorable conditions for ignition of a gas mixture. The $12.7-$ and $25.4-\mathrm{mm}$-thick layers of 50 -gal/ton oil shale and coal dusts were placed on a $350^{\circ}$ to $390^{\circ} \mathrm{C}$ hot surface, and airflow was then directed over the layers to promote glowing combustion. These irnited layers, with areas of glowing particles ranging from 25 to $50 \mathrm{~mm}$ in diameter, did not ignite the methane-air atmospheres that were then introduced into the enclosure. Instead, the flammable atmospheres reduced and dimmed the glow. Most readily ignited concentrations of methane-air atmospheres range from 5 to 9.5 pit methane. depending on the type of ignition source (23). The methane mixtures utilized in the present tests ranged from 7 to $10 \mathrm{pct}$, and none of these were ignited by the areas of orangered-colored glowing particles, whose temperatures were at least $600^{\circ} \mathrm{C}$. The latest experimentally determined minimum autoignition temperature of a 7-pet methane-air mixture is $601^{\circ} \mathrm{C}$ (24). A spherical stainless steel vessel (coated with boric acid) was used in the determination, and ignition lag times were between 17 and $20 \mathrm{~s}$. Higher temperatures are required to ignite stationary flammable mixtures by an open hot surface, and still higher temperatures are needed to ignite flowing mixtures by a hot surface.

Finally, the part played by a combustible substance placed on a hot surface in the ignition process of a flammable gas mixture, and especially its effect on the ignition temperature of the flammable mixture, is of direct interest. To test this combined effect, Guest (25) placed a very fine bituminous coal on a $12.5-\mathrm{mm}$-wide nickel bar heated to $9.33^{\circ} \mathrm{C}$. At this temperature, a 6-pct natural gas-air mixture in contact with the bare bar was ignited. The presence of the smoldering coal (which did not flame) did not reduce the metal bar temperature at which the gas mixture ignited to below $933^{\circ} \mathrm{C}$. Rather, the presence of the gas mixture suppressed the combustion of the coal. Unlike coal, other substances such as pyritic dust and pine sawdust aided the ignition of the 6-pct natural gas-air mixture by emitting volatiles that reduced the bar temperature necessary for ignition of the flammable mixture. But like coal, these substances had their own combustion suppressed by the gas mixture. When the same test was repeated with a stream of air blown over the coal to aid combustion, the temperature of the bar required to ignite the flammable mixture was lowered by $130^{\circ} \mathrm{C}$ from that required for ignition by the bare bar. Guest's results are analogous to the results seen with the oil shale and coal dust layers in the flammable atmospheres. These latter atmospheres interfered with the glowing combustion and dimmed it.

Crookston conducted tests similar to the ones in this program using a 10 -pct methane-air mixture (10). A hotplate capable of being heated to temperatures in excess of $538^{\circ} \mathrm{C}$ was utilized. Various shapes, sizes, and thicknesses of layers were used in the tests with three oil shale dusts of 15,25 , and $35 \mathrm{gal} / \mathrm{ton}$. The flammable mixtures were not ignited in any of the tests. Thus, results of both test programs are in agreement regarding the inability of the hot layers of oil shale to ignite a flammable mixture of methane and air. Both Crookston's results and the results of the tests conducted by the Bureau are to be expected. The temperatures of the hot surfaces of both the hotplates and the dust layers are much lower than the ones quoted by (iuest for ignition of such flammable mixtures by hot surfaces. Even the flammable gases gentrated by the heated layers themselves, which can probably be ignited at lower surface temperatures than those required for the methane-air mixture, were not ignited by the heated oil shale layers.

\section{CONCLUSIONS}

The minimum hot-surface ignition temperatures of a suite of three fine oil shale dusts and one coarse oil shale dust and of one fine and one coarse coal dust were determined and the fire hazards of the layer ignition process evaluated.

Test results are summarized as follows:

- Hot-surface ignition temperatures increased with decreasing oil shale grade and layer thickness.

- Hot-surface ignition lemperatures increased with increasing particle size.

- Hot-surface ignition temperatures for the 50 -gal/ton oil shale were similar to those of Pittsburgh coal dust for the 12.7. and $25.4-\mathrm{mm}$-thick layers. For the $6.4-\mathrm{mm}$-thick layers, the minimum ignition temperature of the oil shale was lower than that of the coal by $50^{\circ} \mathrm{C}$.
- Glowing particles were observed in the standard layer tests only with the 50 galiton oil shale dust, most ofterl with the 6.4 -mm-thick layers. They were also produced when the oil shales were sprinkled on the hotplate when its surface temperature was $>340^{\circ} \mathrm{C}$. The surface temperature that produced glowing particles increased with decreasing oil shale grade. The number of glowing particles and their intensity increased with increasing oil shale grade. Sprinkled coal dust particles did not gloweven at a surface temperature of $390^{\circ}$ ( ${ }^{\circ}$. Thus, to attain glowing, relatively high surface temperatures combined with sufficient air are needed.

- Flames were not observed in any of the layer tests, and the maximum lemperature attained inside the geometrie centers of the shale layers were not higher than $400^{\circ}$ ("in most 
cases. Higher temperatures resulted only when the layers were heated on the hotplate at temperatures much higher than the minimum hot-surface ignition temperatures. Flames were observed only when particles of oil shale or coal were sprinkled on a cherry-red hot surface of a heating coil at about $750^{\circ}($.

- During the hotplate tests, large amounis of volatiles and smoke were generated by the oil shale and coal dusts. These volatiles contained flammable gases such as hydrocarbons, $C($, and at times hydrogen, but their concentration. were below the flammable limits of such gases and they were not ignited by the reacting hot layers in any of the standard tests. These volatiles were seldom ignited even by a lighted match unless the hotplate surface temperature was high enough $\left(-370^{\circ}\right.$ () to induce extensive decomposition of a rich oil thale, e.g., 50-gal ton shale.

- Flammable methane-air atmospheres that passed over reacting rich oil shale or coal dust layers on $350^{\circ}$ to $390^{\circ}$ ( hot surfaces were not ignited by them evei when these layers were glowing. To ignite such atmospheres, much higher laver temperatures or flaming combustion is required. Such temperatures were not attained in any of the layer tests, even at high hotplace surlace temperatures.

- The minimum hot-surface ignition temperatures of oil shale dust layers increase gradually when the layers are heated on surfaces whose temperatures are initially slightly lower than the layers minimum ignition temperatures but are then slowly raised to levels higher than the minimum ignition temperatures. These results suggest that dust layers that slowly accumulate on hot surfaces are safer than freshly deposited dust.

- In tests with coarse oil shale and coal dusts, the temperatures inside the layers did not rise $50^{\circ} \mathrm{C}$ above the hot-surface temperature, even when the hotplate temperature was close to $400^{\circ} \mathrm{C}$ and the oil shale and coal dusts underwent decomposition. Therefore, the minimum ignition temperatures of the coarse dusts are higher than $400^{\circ} \mathrm{C}$.
The fire halatds of oil shate dust lavers on hot surfaces with remperatures up to $4000^{\circ}$ ( are those associated with smoldering and glowing combustion. In locations where such hazards are unaceptable, the maximum surface temperature of heat-producing equipment should be at least $10^{\circ} 1020^{\circ} C^{\circ}$ lower than the minimum laver ignition emperature of the dust. As demonstrated in this study, the minimum hot-surface ignition temperatures of oil shale dust layers vary significantly with kerogen content, particle sise, and layer thickness, and these parameters should be considered when specifying maximum surface temperatures.

Federal standards for underground mines that operate within a combustible ore body and liberalle methane, and in which a concentration of $0.25 \mathrm{pet}$ or more of methane has been detected or ignition of methane has occurred, require that all electrical and internal-combustion-powered equipment used in or beyond the last open crosscut be approved by the U.S. Mine Safety and Health Administration under the applicable requirements of $30 \mathrm{CFR}$, parts 18 through $36(26)$. This would limit the maximum surface temperatures of electrical and mechanical equipment to $150^{\circ} C^{\circ}$ and of the external surfaces of exhaust systems of diesel-powered equipment to $204^{\circ} \mathrm{C}$, as in coal mines. These temperatures are $50^{\circ} \mathrm{C}$ less than or near the $200^{\circ} \mathrm{C}$ minimum hot-surface ignition temperature determined in this study for the 25.4-mm-thick layers of fine, 50-gal/ton oil shale dust. The implementation of these surface temperature limits in underground gassy oil shale mines should prevent the ignition and smoldering combustion of oil shale dust layers in all but the richest shale deposits $(>50)$ gal/ton). Indeed, the temperature limits are conservative for the majority of existing oil shale mines. In the event that a dust layer would ignite because of contact with a hot surface below $400^{\circ} \mathrm{C}$ in the presence of a flammable methane-air mixture, the smoldering layer would not attain high enough temperatures to ignite the gas mixture. 


\section{REFERENCES}

1. Sapko, M. J., J. K. Richmond, and J. P. McDonnell. (ontinuous Monituring of Methane in a Deep Oil Shale Mine. Paper in 15 h Oil Shale Symposium Proceedings (Ciolden. ( $(0$, Apr. 28-30, 1982). (0) Sch. Mines Press, (iolden, CO, 1982, pp. 320-340.

2. Richmond, J. K., M. J. Sapko, and L. I. Miller. Fire and Explosion Properties of Oil Shale. BuMines RI 8726, 1982, $39 \mathrm{pp}$.

3. U. S. Code of Federal Regulations. Title 30-Mineral Resources; Chapter I-Mine Safety and Health Administration, Department of Labor; Subchapter B--Testing, Evaluation, and Approval of Mining Products; Part 31-Diesel Mine Locomotives, 31.4; July 1, 1987.

4. __ Title 30-Mineral Resources; Chapter !-Mine Satets and Health Administration, Department of labor: Subchapter B-Testing. Evaluation, and Approval of Mining Products; Part 36-Mobile Diesel-Powered Transportation Equipment for Ciassy Noncoal Mines and Tunnels, 36.25; July 1, 1987.

5. Title 30-Mineral Resources; (hapler 1-Mine Safeny and Health Administration, Department of Labor; Subchapter B-Testing, Evaluation, and Approval of Mining Products; Part 18-Electric Motor-Driven Mine Equipment and Accessories, 18.23; July $1,1987$.

6. National Fire Protection Association (Quincy, MA). National Electrical Code 1987. Art. 500, pp. 70-423 through 70-430.

7. Nagy, J., A. R. Cooper, and H. (i. Dorsett, Ir. Explosibility of Miscellaneous Dusts. BuMlines RI 7208, 1968, 31 pp.

8. Dorsett, H. G., Jr., M. Jazobson, J. Nagy, and R. P. Williams. Laboratory Equipment and Test Procedures for Evaluating Explosibility of Dusts. BuMines RI 5624, 1960, $21 \mathrm{pp}$.

9. I.itchfield, E. L., T. A. Kubala, T. Schellinger, F. J. Perzak, and D. Burgess. Practical Ignition Probloms Related to Intrinsic Salety in Mine Equipment. Four Short-Term Studies. BuMines Kl 8464, 1980, $18 \mathrm{pp}$.

10. Crookston, R. B., M. T. Atwood, R. E. Williams, and M. D. McCuire. An Evaluation of the Fire and Explosion Hazards of Oil Shale Mining and Processing. Volume 1: Analytical Studies and Accident Scenarios (contract J0275001, Tosco Corp.). BuMines OFR 12(1)-85, 1983, 268 pp.; NTIS PB 85-165492.

11. National Materials Advisory Board. Committee on Evaluation of Industrial Hazards. Classification of Dusts Relative to Electrical Equipment in Class II Hazardous Locations. Natl. Acad. Sci., Washington, $D C, N M A B 353-4,1982,51 \mathrm{pp}$.

12. Nagy, J., and H. C. Verakis. Development and Control of Dust

Explosions. Mareel Dekker, Inc., 1983, pp. 61-74.

13. Coward, H. F, and (i. W. Jones. Limits of Flammability of Gases and Vapors. BuMines B 503, 1952, pp. 5-8.
14. Iee, 1. (., and H. Y. Sohn. Experimental Investigation and Mathematical Modeling of the Ignition of an ()il Shale Bed with Hol Air. Ind. \& Eng. (hem. Process Des. and Dev., 1. 24, 1985, Pp. $753-761$.

15. Nagy, J, H. (i. Dorsett, Ir., and A. R. Cooper. Explosibility of Carbonaceous Dusts. BuMines RI 6597, 1965, 30 pp.

16. Bowes, P. ( ., and S. E. Townshend. Ignition of Combustible Dusts on Hot Surfaces. I. Appl. Physs, (Brit.), v. 13, No. 3, 1962, pp. $105-114$.

17. Yoshizawa, Y., and H. Kubota. Experimental Study on Gas Phase Ignition of Cellulose Under Thermal Radiation. Paper in Nincteenth Symposium (International) on Combustion (Haifa, Israel. Aug. 8-13, 1982). Combustion Inst., Pittsburgh, PA, 1982. pp $787-795$.

18. Galan, M. A., and J. M. Smith. Pyrolysis of Oil Shale: Experimental Study of Transport Effects. AlCht J., v. 29, No. 4. 1983, pp. 604-610.

19. Campbell, J. H., (i. H. Koskinas, N. D. Stout, and T. T. Coburn. Oil Shale Retorting: Effect of Particle Size and Heating Rate on Oil Evolution and Intraparı icle Oil Degradation. In Situ, v. 2, No. 1. 1978, pp. 1-47.

20. Suuberg, E. M., W. A. Peters, and J. B. Howard Product Compositions and Formation Kinetics in Rapid Pyrolysis of Pulverized Coal-Implications for Combustion. Paper in Seventeenth Symposium (International) on Combustion (Leeds, England, Aug. 20-25, 1978). Combustion Inst., Pittsourgh, PA, 1978, pp. 117-130.

21. Palmer, K. N. and P. S. Tonkin. The lgnition of Dust Layers on a Hot Surface. Combust, and Flame, v. 1, 1957-58, pp. 14-18.

22. Manor, Y., E. M. Suuberg, M. Ho, and H. L. Toor. The Innition and Combustion Behavior of Spent Shale Particles. Paper in Nineteenth Symposium (International) on Combustion (Haifa, Israel, Aug. 8-13, 1982). Combustion Inst., Pittsburgh, PA, 1982, pp. 1093-1103.

23. Singer, J. M., E. B. Cook, and J. Cirumer. Equivalences and Lower Ignition Limits of Coal Dust and Methane Mixtures. BuMines RI 6931, 1967, $35 \mathrm{pp}$.

24. Robinson, C., and D. B. Smith. The Auto-lgnition Temperature of Methane. J. Hazard. Mater., v. 8, 1984, pp. 199-203.

25. Ciuest, P. G. Ignition of Natural Cias-Air Mixtures by Heated Surfaces. BuMines TP 475, 1930, 59 pp.

26. U.S. Code of Federal Regulations. Title 30-Mineral Resources; Chapter 1-Mine Safety and Health Administration, Department of Labor; Subchapter N-Metal and Nommetal Mine Safety and Health; Part 57-Safety and Health Standards-Underground Metal and Nonmetal Mines; 57.223(2); July 1, 1987. 


\section{APPENDIX.-MAXIMUM TEMPERATURES ATTAINED INSIDE VARIOUS LAYERS OF OIL SHALE AND COAL DUSTS}

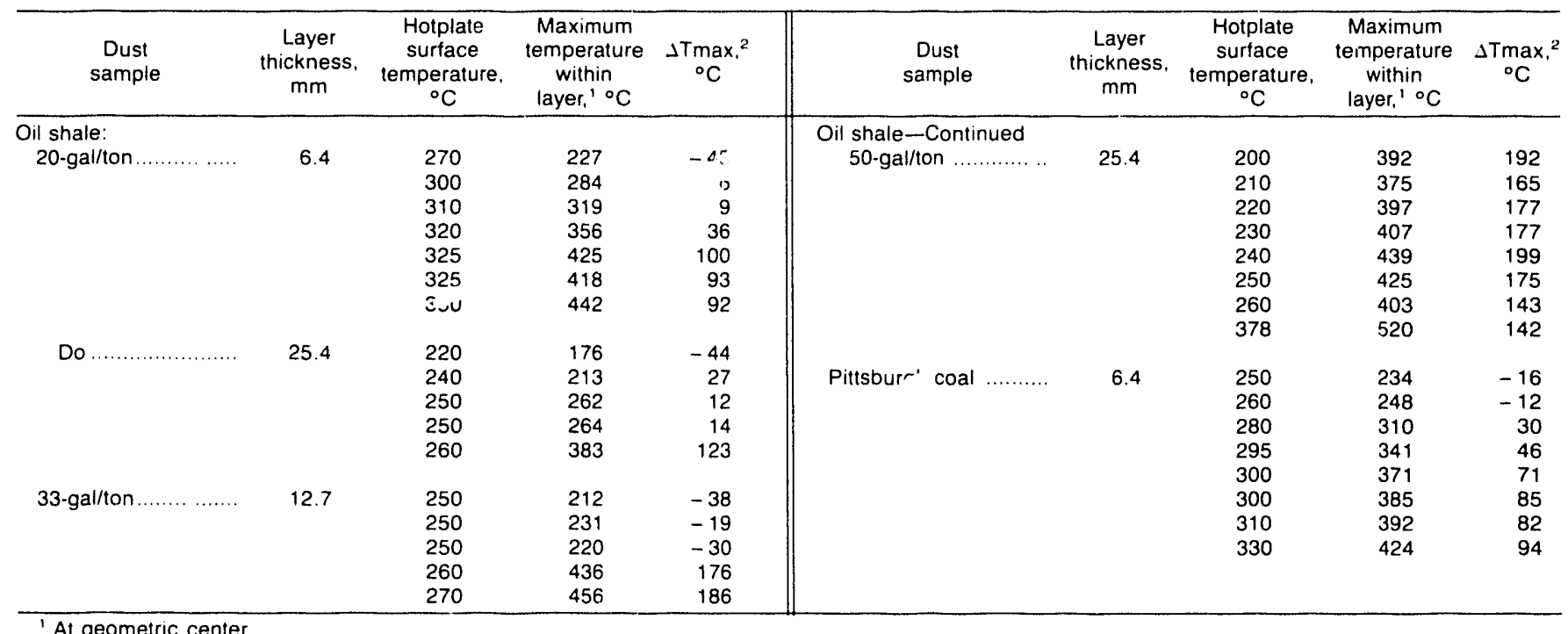

\footnotetext{
At geometric center.
}

2 Difference between maximum temperature attained at geometric center of layer and hot-surface temperature. 


\title{
PART 3: FLAMMABILITY AND SPONTANEOUS COMBUSTION POTENTIAL OF COARSE OIL SHALE AND EFFECTIVE METHODS OF EXTINGUISHMENT
}

\author{
By Staff, Pittsburgh Research Center, U.S. Bureau of Mines
}

\begin{abstract}
The U.S. Bureau of Mines conducted large-scale ignition and fire extinguishment tests on up to 85-ton oil shale rubble piles at the Bureau's Lake Lynn Laboratory. The objectives were to identify the ignition potential of rubble piles and to investigate different methods of extinguishing rubble fires. Large rubble piles of oil shale were easily ignited with burning liquid fuels. However, ignition or spontaneous combustion did not occur when a lowtemperature heat source was applied for a long duration. Once ignited, oil shale rubble pile fires became increasingly difficult to extinguish as the fire progressed into the deeper recesses of the pile. Foam blankets were not particularly effective in suppressing deep-seated fires because of the short lifetimes of the foams. Water was effective in extinguishing deep-seated oil shale fires but not particularly efficient. It took up to 1.7 times as much water to extinguish a fire as anticipated on the basis of a simple cooling model, assuming $100 \mathrm{pct}$ utilization.
\end{abstract}




\section{INTRODUCTION}

Unplanned fires are a constant threat to the economic well-being and personnel safety of organizations that mine, process, or stockpile combustible materials such as oil shale and coal. The potential for oil shale fires has been recognized since the native Indians and early pioneers attempted to use pieces of oil shale to construct campfires (l). In some countries where there are boilers or furnaces designed to handle high-ash fuels, raw oil shale is used as an energy source. Accidental fires have occurred in underground oil shale mines as a result of the ignition of retort gases, methane, and liquid fuels $(2-4)$. Fires in surface facilities have occurred in crushers, in the vicinity of retorts, and in stockpiles or wastepiles. The fire hazard in oil shale mines is likely to be less severe than in coal mines or coal processing plants, but the quantity of material to be handled is so large that fires in oil shale mining operations are almost inevitable.

Spontaneous combustion of oil shale is ill defined and difficult to simulate in controlled experiments of any reasonable size. Those instances in which spontaneous combustion or self-heating of oil shale is thought to have occurred have been in large outdoor stockpiles where the source of heat is the sun and where wind and precipitation may play important roles. Small-scale self-heating tests of oil shales in an adiabatic calorimeter indicated a low self-heating tendency, comparable to that of the higher rank bituminous coals (5). However, smoke has been seen coming from a stockpile at a western oil shale mine where the size distribution ranges from dust to about 6 in $(15 \mathrm{~cm})$. At this location, the self-heating was observed and has been easily controlled by digging out and isolating the hot spots. In a large waste pile of raw oil shale dumped on the side of a gully near the crusher at the Anvil Points Mine in Colorado, fires have been burning for a considerable period of time, producing air pollution and retorted oil. The Tosco Corp., under Bureau contract, was commissioned to investigate the nature of this fire and recommend methods for extinguishment. It concluded that hot spent shale dumped over the raw shale from the crusher was probably the initial ignition source (6). However, some of the hot spots did not appear to be related to the dumped spent shale.

In an effort to provide additional information on the fire hazards of oil shale, personnel at the Bureau's Laki Lynn Laboratory performed suppression experiments on burning oil shale rubble piles to evaluate procedures found effective for extinguishing coal and wood fires. A slow-heating test was also conducted to determine if the rubble could be ignited by a low-temperature, long-duration heat source, simulating a selfheating event.

To help define a strategy for combating unwanted oil shale fires both underground and on the surface, the present strategy for fighting coal mine fïres was reviewed and those features applicable to oil shale fires are summarized in this report.

\section{EXPERIMENTAL PROCEDURES}

\section{PILE CONSTRUCTION AND INSTRUMENTATION}

Over 250 tons of $^{2}$ Colorado oil shale was shipped to the Lake Lyrn Laboratory for fire tests. From this tonnage, four piles were constructed against a limestone highwall, and dirt was filled at the ends to stimulate a section of a large rubble pile blasted from a face or dumped over the edge of a large storage pile (fig. 3-1). The oil shale, as received, contained about 35 -gal/ton kerogen, ranged in size from $<1$ to 10 in $(25.4 \mathrm{~cm})$, varied in color from a light buff to a dark brown or black, and generally was striated.

During formation of each test pile, a predetermined number of sheathed thermocouples were inserted. These were subsequently used to monitor temperatures at various locations in the pile. Where it was expedient, the thermocouples were grouped in bundles of two, three, or four, so that they could be located at predetermined depths along the centerline of the pile. Most of the thermocouples were placed on the centerline plane starting at the toe of pile and extending into the pile at $2-\mathrm{ft}(61-\mathrm{cm})$ intervals to within $1 \mathrm{ft}(30.5 \mathrm{~cm})$ of the bottom. Others were placed on $2-\mathrm{ft}(61-\mathrm{cm})$ spacings above the bottom rows commencing about $1 \mathrm{ft}(30.5 \mathrm{~cm})$ from the bottom. Additional thermocouples were placed on either side of the centerline about $1 \mathrm{ft}(30.5 \mathrm{~cm})$ beneath the surface. This configuration of thermocouples made it possible to follow the progress of the fire. The thermocouples were fed into a 48-channel analog data logger and relayed to a data acquisition computer. The temperature data in the various segments of the

'Italic numbers in parentheses refer to items in the list of reterences at the end of puri ?.

"In this report, the term "ton" meams short ton. pile were superimposed on the videotape from two television monitors focused at right angles to each other. Thus, the decrease in temperatures could be detected during the fire suppression exercises. These readings were updated every $10 \mathrm{~s}$ and stored every 5 to $15 \mathrm{~min}$ to provide a continuous record of temperatures throughout the tests. Each burn was recorded on videotape.

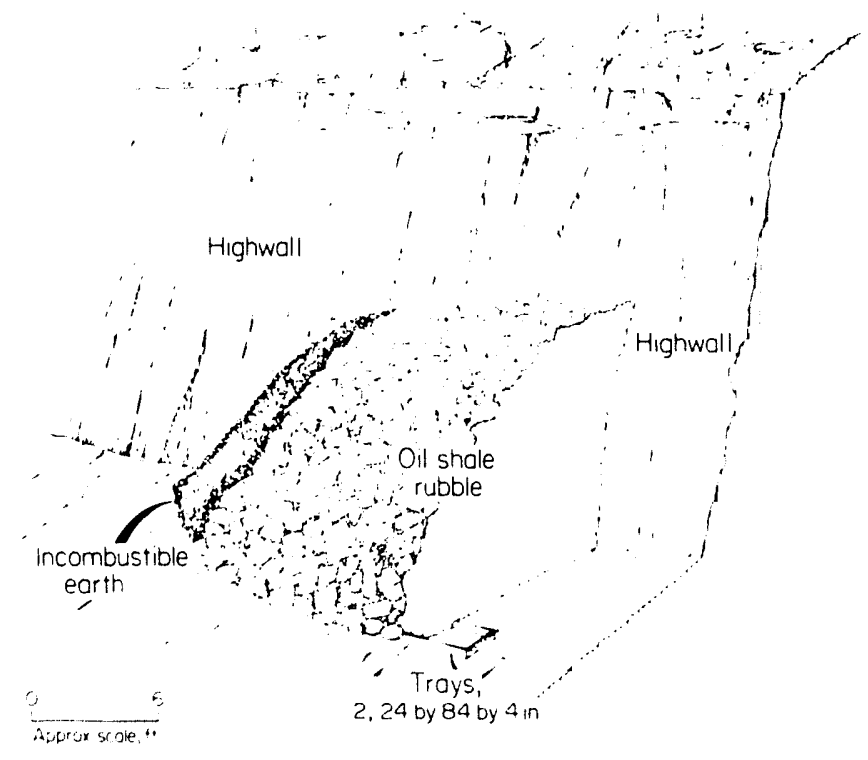

Figure 3-1.-Rubble pile configuration. 


\section{IGNITION SOURCES}

The oil shale rubble fires were ordinarily ignited with 20 gal $(75.7 \mathrm{~L})$ of diesel fuel contained in two $2-\mathrm{ft}(61-\mathrm{cm})$ by $7-\mathrm{ft}$ $(213-\mathrm{cm})$ by 4 -in-deep $(10.2-\mathrm{cm})$ trays embedded in the toe of the piles. The diesel fuel was ignited by the flame from a small pouch of black powder, which was initiated from a remote location using electric matches. In some cases, a small amount of gasoline was added to the diesel fuel to facilitate ignition.

In one of the fires (rubble fire 2), an electric heater was used to slowly heat the center of the pile in order to simulate a spontaneous combustion event (fig. 3-2). The heater consisted of a $55-\mathrm{gal}(208-\mathrm{L})$ metal drum $(36 \mathrm{in}(91.4 \mathrm{~cm})$ long by $22 \mathrm{in}(55.9 \mathrm{~cm})$ diam) equipped with 1 wo $U$-shaped heating elements attached to the drum lid. The elements were 28 in $(71.1 \mathrm{~cm})$ long with a $\mathrm{k}-\mathrm{in}(1.27-\mathrm{cm})$ diam and could produce $2,500 \mathrm{~W}$ at $240 \mathrm{~V}(8,530 \mathrm{Btu} / \mathrm{h})(2,151 \mathrm{kcal} / \mathrm{h})$. The voltage to the heater was independently controlled by a variable transformer.

\section{EXTINGUISHINĪ̄ AGENTS}

A number of different extinguishing agents were used in the fire suppression activities. They were selected on the basis of general applicability and availability and are listed here for reference.

- Ansul Protein Foam-A high-density foam containing hydrolized protein;

- Ansulite-An aqueous film-forming foam containing a fluorosurfactant;

- DAP-Diammonium phosphate;

- MSA General-Purpose Foam-A foaming agent based on alky-aryl sulfates and alcohol, used with both high- and low-expansion nozzles:

- MSA Ultrafoam-A foaming agent containing a variety of surfactants and a biodegradable detergent; and

- Water.

Ordinary water, or water with additives that decrease the surface tension, yields a better penetrating quality than that

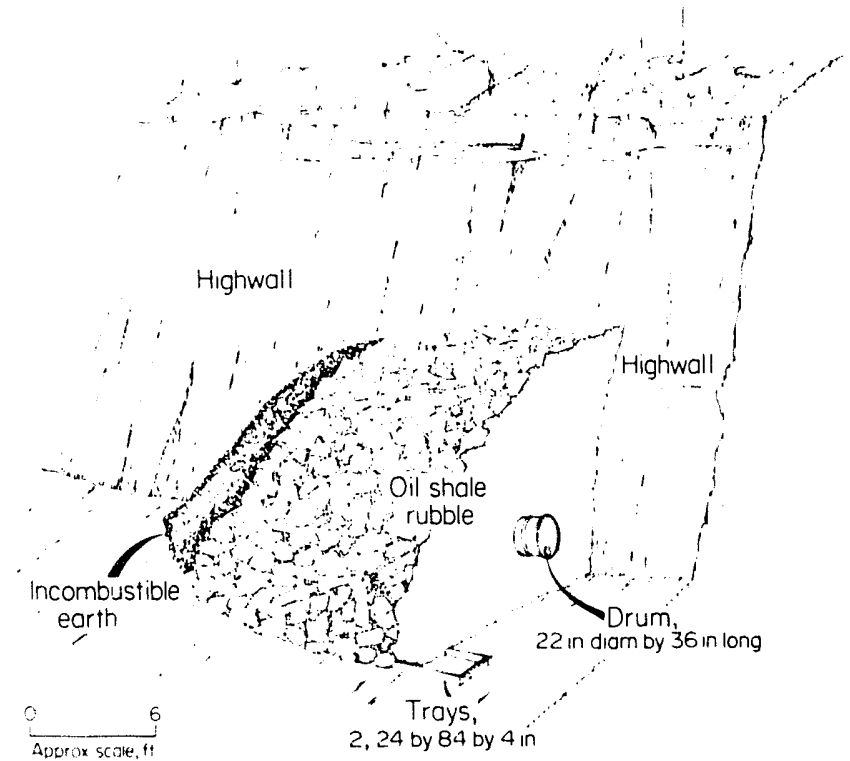

Figure 3-2.-Rubble pile configuration with heater.

normally obtained with a foam. Since in some mine fire situations a vast supply of water may not be readily available to fight a fire and since in some instances it is necessary to control the spread of surface flames, suppression with foams was included in the test program.

Although it is to be expected that medium- to highexpansion foams have shorter lifetimes than low-expansion ones, they were included along with low-expansion foams in the test program. How the wind might affect the application of high-expansion foam was of interest. It was decided to include a wide range of foam densities.

\section{EXPERIMENTAL RESULTS}

\section{RUBBLE FIRE 1}

The first oil shale rubble pile was about $28 \mathrm{ft}$ along the highwall, was piled over $10 \mathrm{ft}(3.04 \mathrm{~m})$ high against the highwall, and had a base of $10 \mathrm{ft}(3.04 \mathrm{~m})$ from the toe to the highwall. It contained approximately 85 tons of oil shale. There were 21 thermocouples implanted in the pile to monitor the progress of the fire (fig. $3-3$ ). The pile was ignited with 20 gal of diesel fuel placed in 1 wo $2-\mathrm{ft}(61-\mathrm{cm})$ by $7-\mathrm{ft}(213-\mathrm{cm})$ by 4 -in-deep $(10.2-\mathrm{cm})$ tray's embedded in the toe of the pile.

The ignition, which occurred about $12: 30$ p.m., is shown in figure $3-4$. The pile burned about $25 \mathrm{~h}$ before suppression activities were begun. During the first hours of the burn, following the depletion of the diesel fuel, flames from the burning shale reached heights of 6 to 8 ft $(1.8$ to $2.44 \mathrm{~m}$ ) (fig. 3-5). The fire was partially supported by a nearly constant wind blowing across the pile.

W'ind gusts were occasionally up to $750 \mathrm{ft} / \mathrm{min}$ (228 $\mathrm{m} / \mathrm{min}$ ) during the first day of the burn and up $10600 \mathrm{ft} / \mathrm{min}$ $(183 \mathrm{~m} / \mathrm{min})$ the second dav, subsiding only moderately overnight. The rate of spread of the heat and flame fronts into and across the surface of the burning oil shale pile seems to have been governed, at least in part, by the textural makeup of the pile. The surface of pile 1 consisted of a relatively large proportion of coarse shale (fig. 3-6) providing ample passageways for air to reach the fire area. The strong, steady wind from the southeast at the time of this burn helped accelerate the burn, which in $23 \mathrm{~h}$ spread up across much of the surface with temperatures as high as $1,100^{\circ} \mathrm{C}$. Simultaneously, the fire was penetrating the pile at a slower rate, reaching a depth of 2 or more feet $(61 \mathrm{~cm})$ from the surface and near the back of the pile in about $27 \mathrm{~h}$. The surface and horizontal velocities of the leading edge of the combustion are shown in figure 3-7. The surface velocity was constant at $2 \mathrm{ft} / \mathrm{h}(6 \mathrm{l} \mathrm{cm} / \mathrm{h})$, and the horizontal velocity was constant at about $0.25 \mathrm{ft} / \mathrm{h}(7.6 \mathrm{~cm} / \mathrm{h})$.

Several suppression trials were conducted with rubble fire 1. They included the use of a high-expansion foam, the use of a low-expansion foam, and finally, the application of water. The exercises with foam were conducted to determine foam life under fire exposure and the effect of foam on surface temperatures. Water was used in an attempt to attack the deeper seated portions of the fire. 
LEGEND

- Thermocouple location and number

Note: probes 14 through 19 are 12 in deep

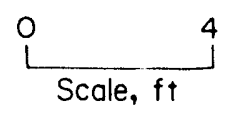
4

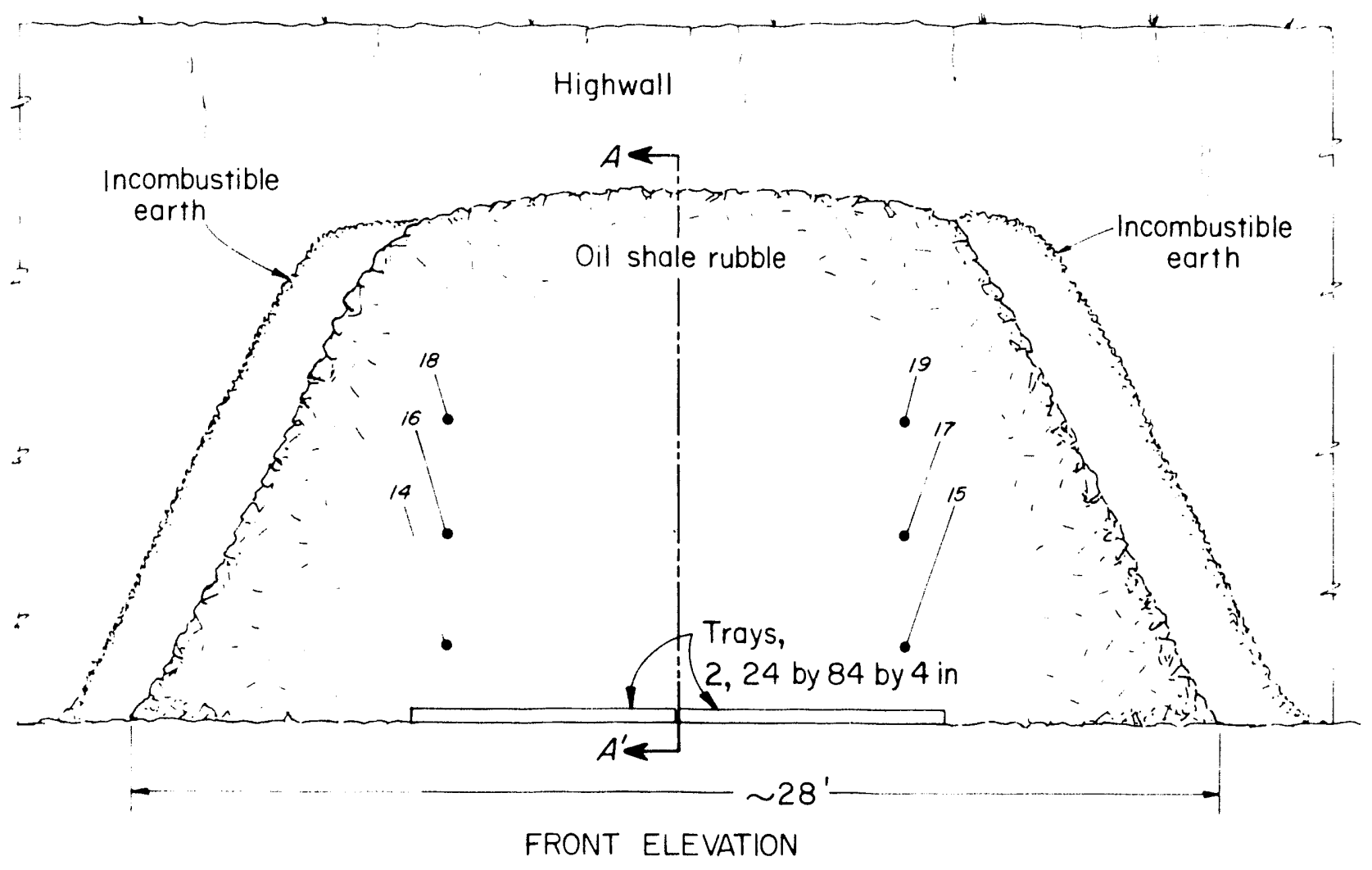

Figure 3-3.-Thermocouple locations for rubble fire 1. 


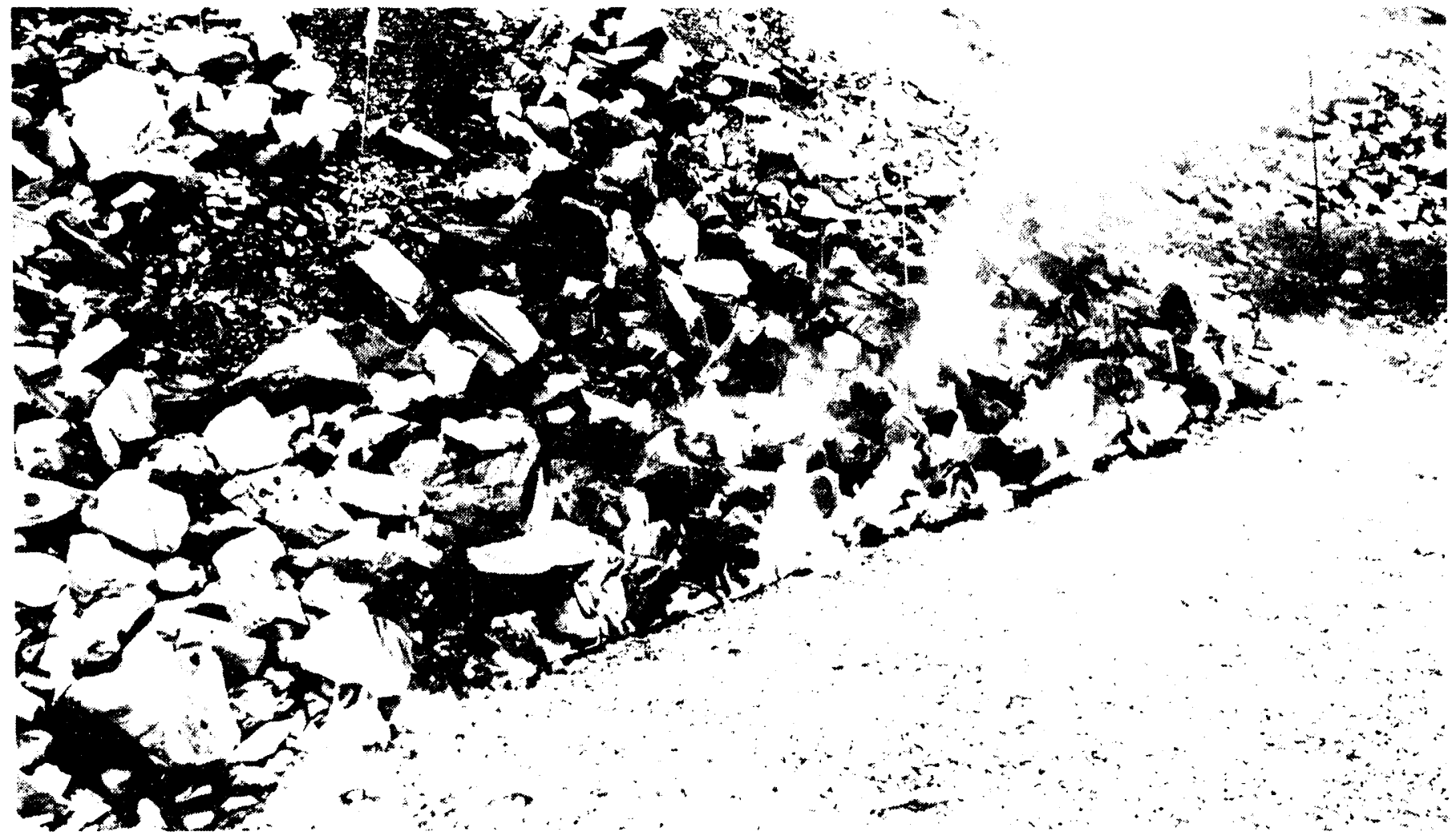

Figure 3-4. - Ignition of rubble fire 1 with diesel fuel.

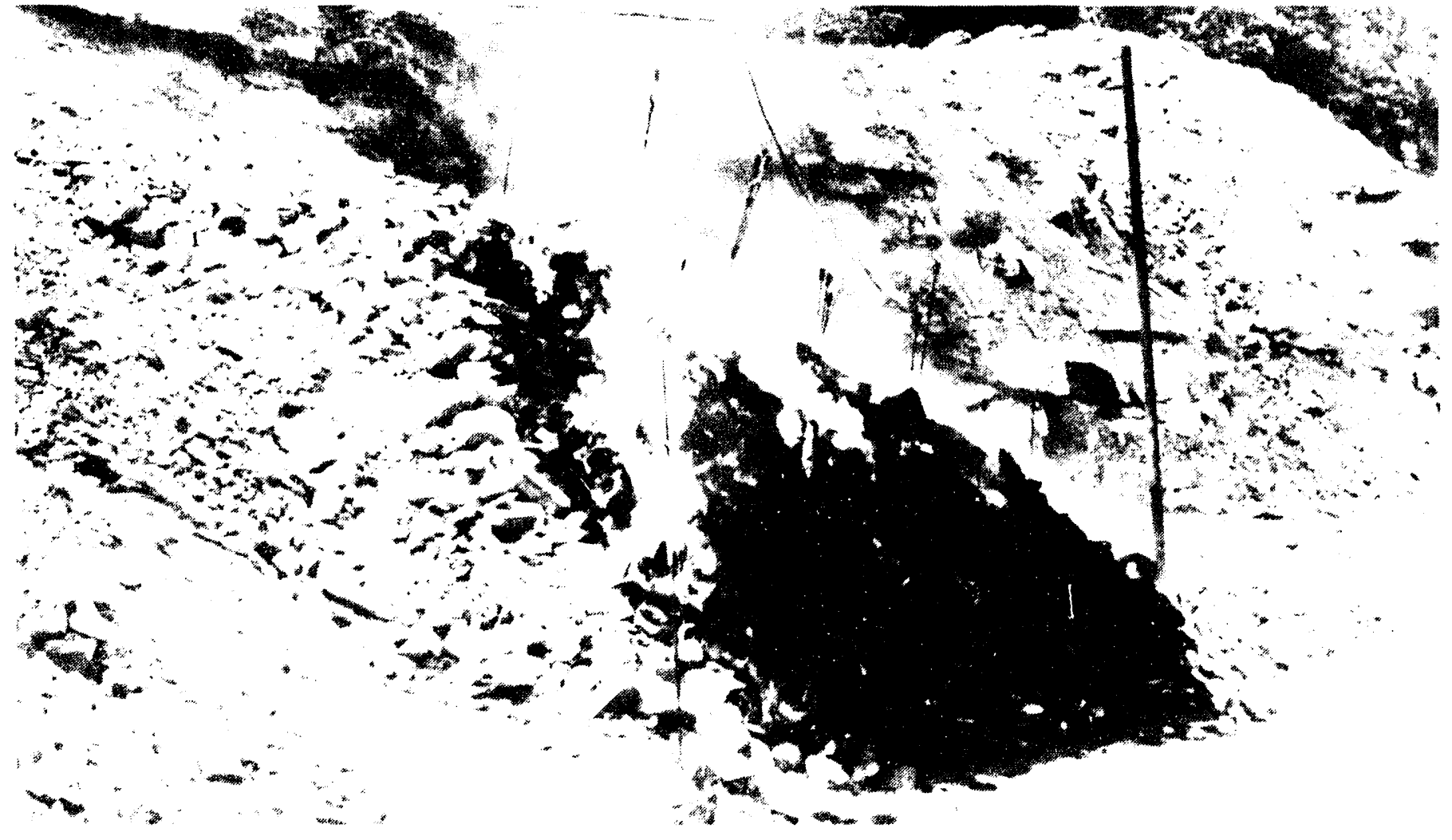

Figure 3-5.-Surface flame advance for rubble fire 1. 


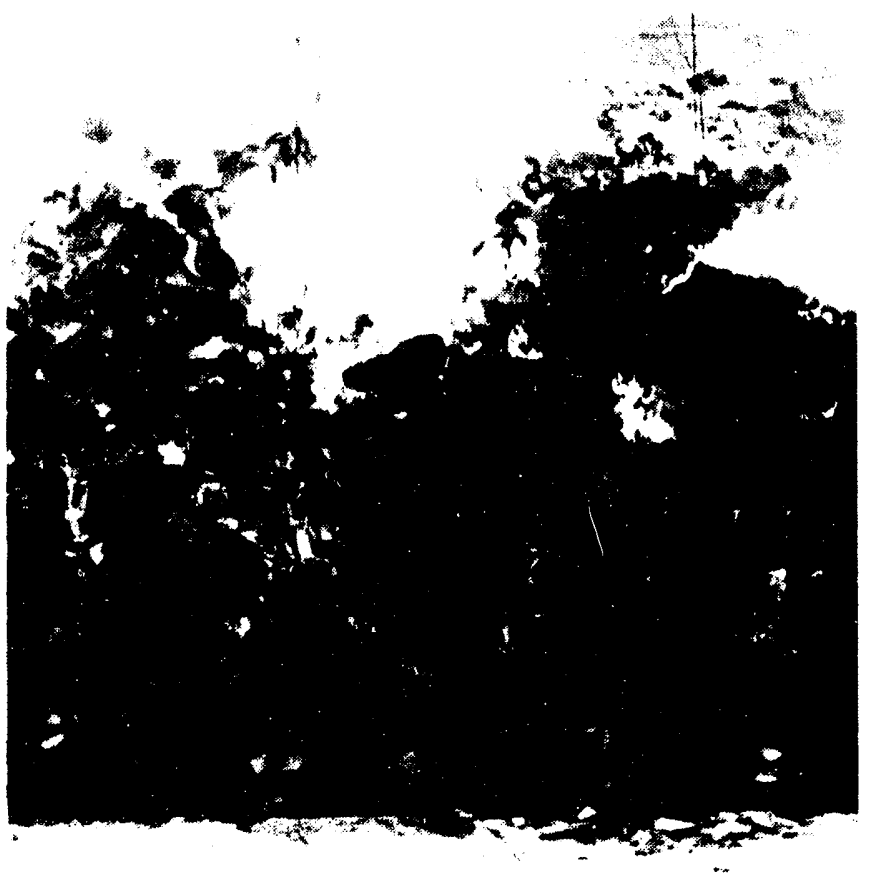

Figure 3-6.-Burning of large lumps of shale in rubble fire 1.

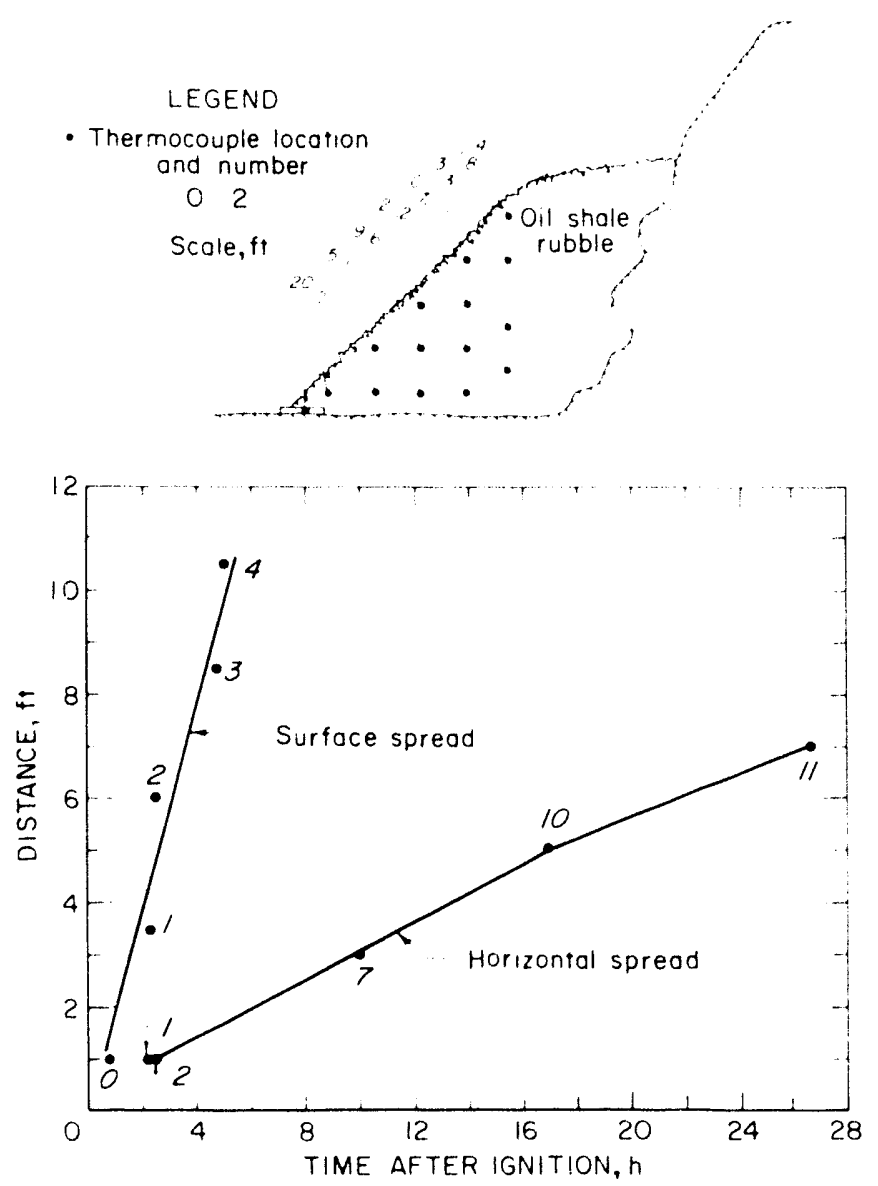

Figure 3-7.-Advance of leading edge of combustion wave in rubble fire 1 .
The experimental results are summarized in table $3-1$ in terms of the amount and lype of extinguishing agent, and time and duration of application, and the qualitative results. To measure the total heat content of the pile and provide a convenient way of illustrating the qualitative effect of the various suppression trials, the weighted-average pile temperature was used. Figure 3-8 shows the suppression trials in graphical form, where weighted pile temperature is plotted as a function of time. The weighted-average pile temperature, $\vec{T}$, for $n$ thermocouples was calculated by (1) assigning an appropriate control mass, $M_{i}$, (control volume, $V_{1}$ ) to each thermocouple, $i$, whose temperature, $T_{i}$, became the mean value for the $i-t h$ control region and (2) averaging over all the control masses; i.e.,

$$
\bar{T}=\frac{M_{1} \bar{T}_{1}+M_{2} \bar{T}_{2}+M_{3} \bar{T}_{3}+\cdots+M_{n} \bar{T}_{n 1}}{M_{1}+M_{2}+M_{3}+\cdots+M_{n}} .
$$

For constant bulk density, $\rho_{\text {hulk }}$.

$$
\mathrm{M}_{1}=\rho_{\text {inulh }}\left(\mathrm{V}_{\mathrm{i}}\right) \text {, }
$$

which yields a density-free relation for the average temperature, $\overline{\mathrm{T}}$; i.e.,

$$
\overline{\mathrm{T}}=\frac{v_{1} \overline{\mathrm{T}}_{1}+v_{2} \overline{\mathrm{T}}_{2}+v_{3} \overline{\mathrm{T}}_{3}+\cdots+v_{11} \overline{\mathrm{T}}_{11}}{v_{1}+\mathrm{v}_{2}+\mathrm{v}_{3}+\cdots+v_{11}} .
$$

This average temperature, $\bar{T}$, gives a measure of the total heat content of the pile and provides a convenient way of illustrating the qualitative effect of the various suppression trials. Since there was no way of estimating runoff, the weightedaverage pile temperature does not provide a quantitative measure of the true effectiveness of the various extinguishing agents.

As indicated in lable 3-1, approximately $25-1 \%$ h $(1,530$ $\mathrm{min}$ ) after lhe oil shale was ignited, a general-purpose foam concentrate wats used with a $750-\mathrm{cfm}\left(21.2-\mathrm{m}^{3} / \mathrm{min}\right)$ foam generator to blanket the burning pile with a high-expansion foam. During the 7 -min application, $3.5 \mathrm{gal}(13.2 \mathrm{~L})$ of foam concentrate and $155 \mathrm{gal}$ (587 L) of water were applied. Initially, the high-expansion foam tended to run off the pile, but as the application continued, a short-lived foam blanket, approximately 10 in $(25.4 \mathrm{~cm})$ thick, was built up and maintained (figs. 3-9 and 3-10). This resulted in a slight drop in the average pile temperature, as indicated in figure 3-8. Shortly thereafter, the foam blanket disintegrated and the average pile temperature rose to a level close to its initial value; the life of the foam blanket, after replenishment, was estimated to be 3 min.

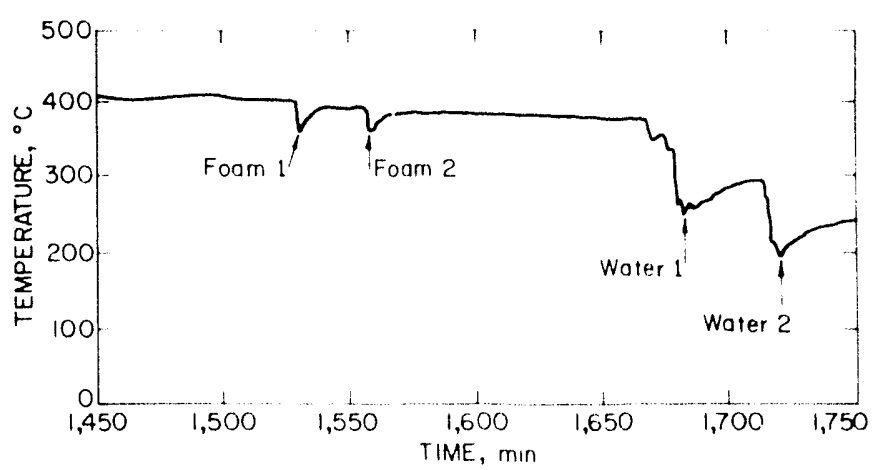

Figure 3-8. Average pile temperature as a function of time for rubble fire 1. 
Table 3-1.-Summary of suppression trials for rubble fire 1

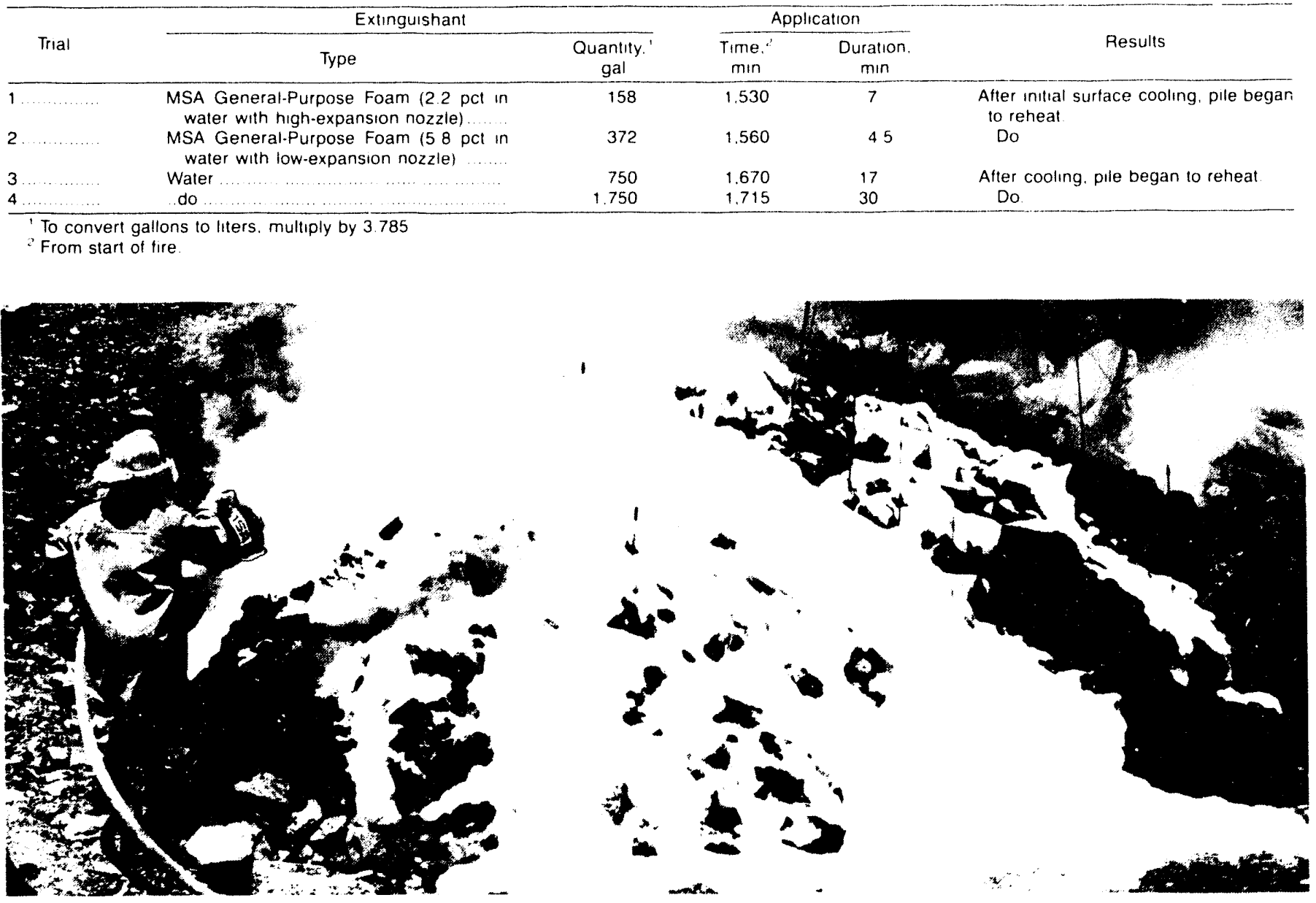

Figure 3-9.-Initial stage of application of high-expansion foam in rubble fire 1.
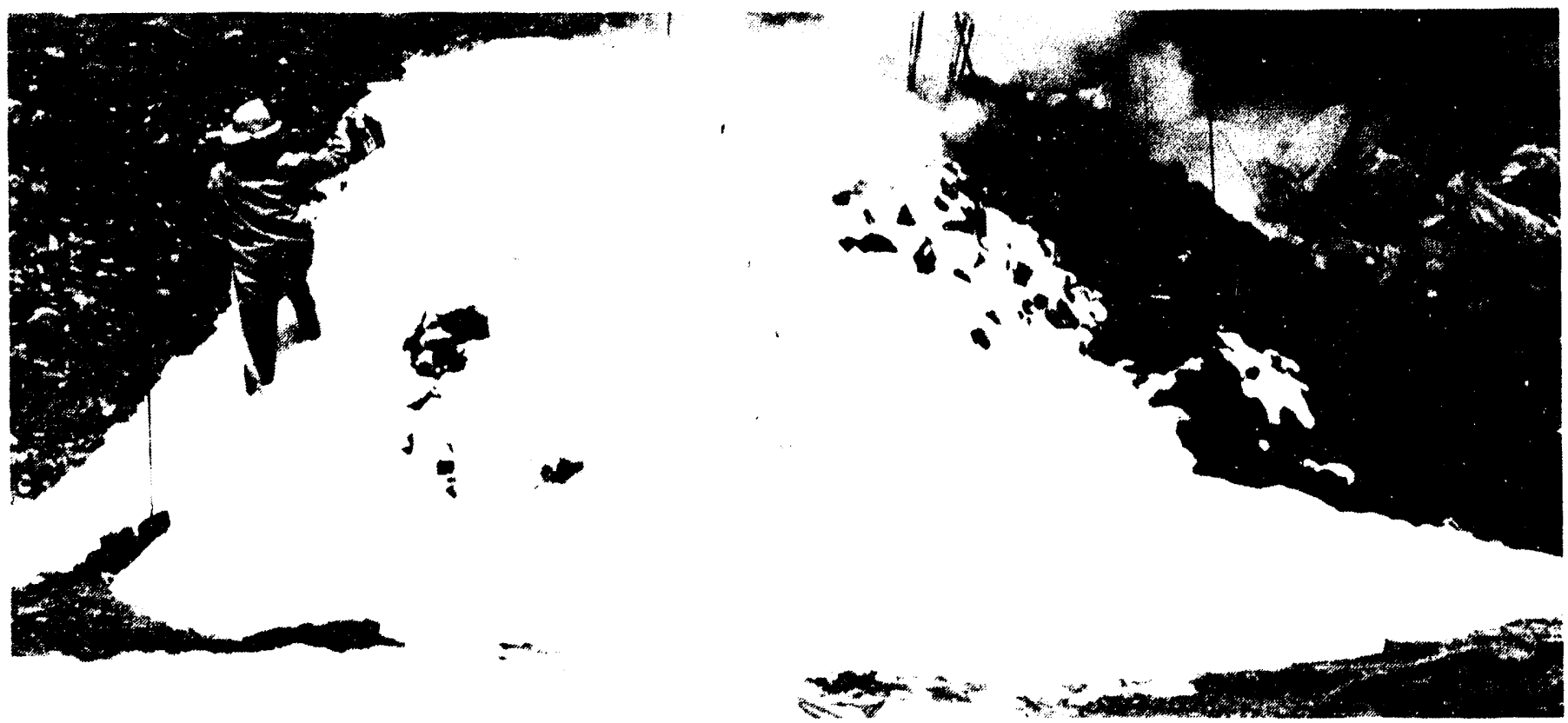

Figure 3-10.-Final stage of application of high-expansion foam in rubble fire 1. 
Approximately 25 min after the first foam application. 21.5 gal $(81 .+1)$ of the general-purpose foam concentrate and about 350 gal $(1,3251$.) of water were applied in 4.5 min using a low-expansion nozzle (fig. 3-11). Again, there was a small drop in average pile temperature (fig. 3-8) while the foam covered the surlace. Shortly thereafter, the foam disintegrated and the average pile temperature rose almost to its original level. The low-expansion foam had a life of about 10 min after the application lerminated. This was significantly longer than the high-expansion foam used initially. Some of the thermocouples indicated a temperature rise while the foam was being applied. This was probably due to a blanketing effect of the foam, which inhibited convectional heat loss. In any case, neither the high-nor low-expansion foams had any significant long-term effect on the course of the rubble fire. In view of this, two applications of water were used in an attempt to extinguish the rubble fire.

The first water application involved about 750 gal $(2,839$ L) of water and was started about 1 h 45 min after the application of the low-expansion foam (fig. 3-12). The application lasted about $17 \mathrm{~min}$ and resulted in a significant drop in average pile temperature, as shown in figure 3-8. However,

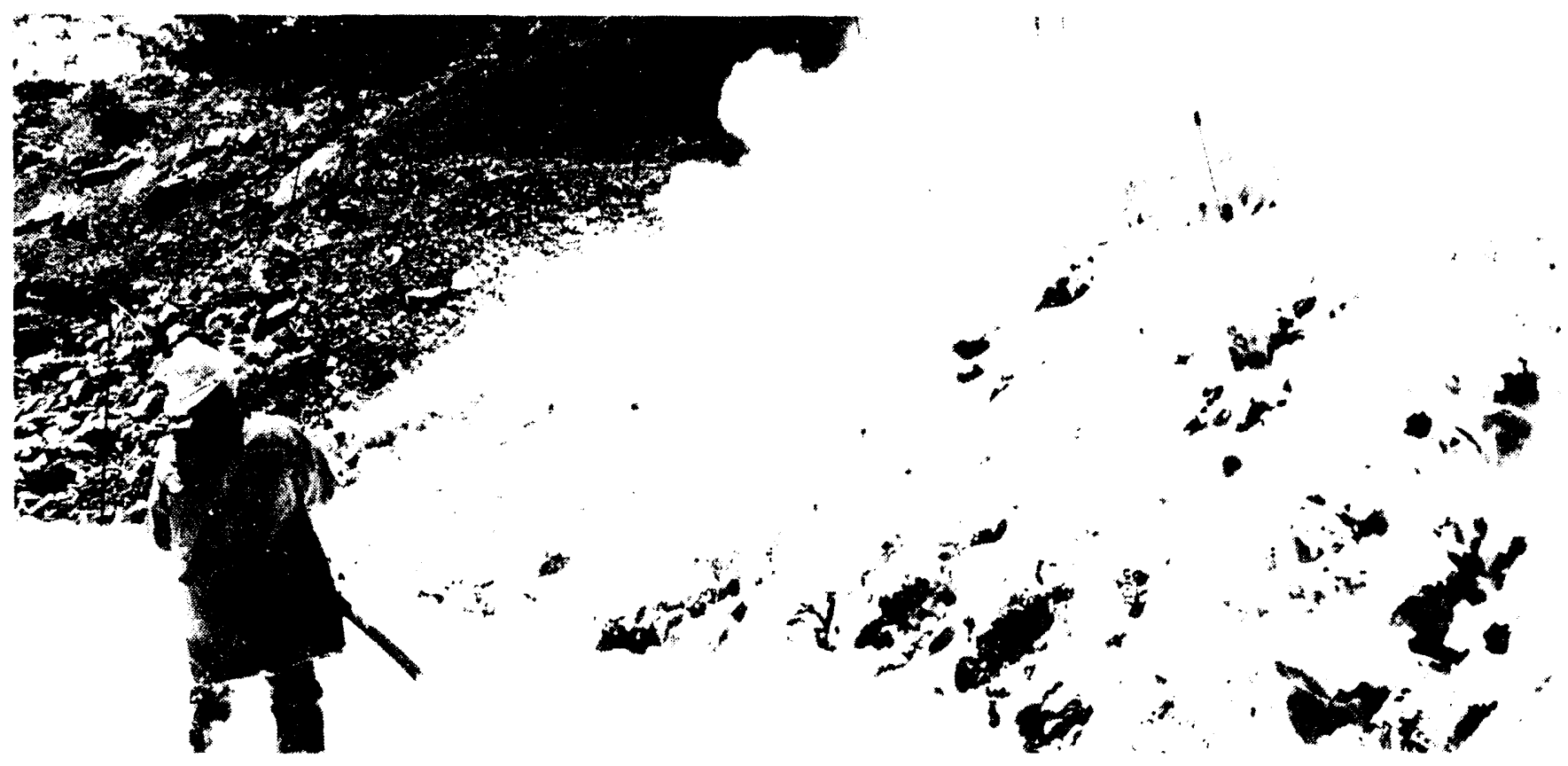

Figure 3-11.-Application of low-expansion foam in rubble fire 1.

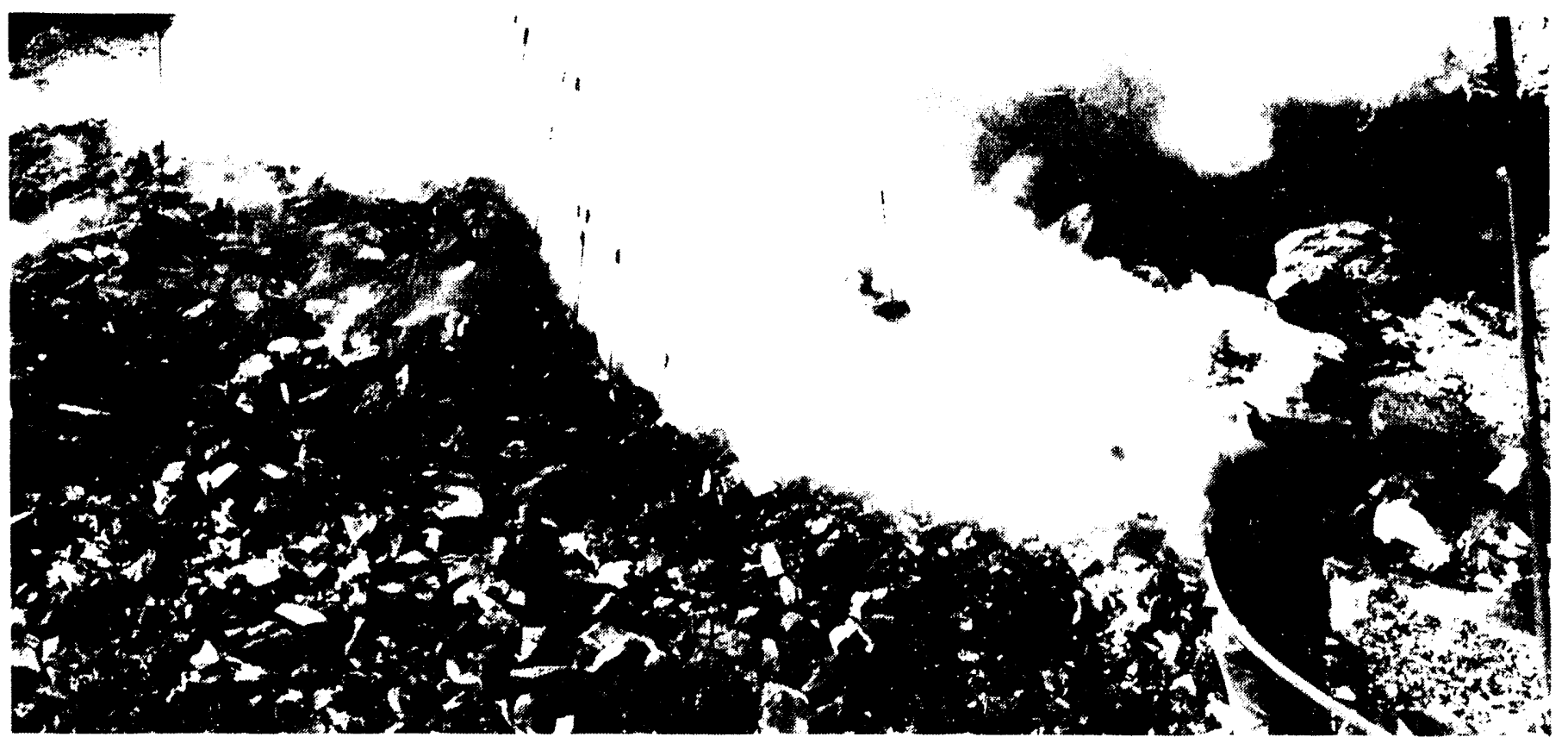

Figure 3-12.-First application of water in rubbie iire 1. 
after termination, the average pile temperature started to rise again and an additional 1,750 gal $(6,6241$ ) of water was applied for about $30 \mathrm{~min}$. The second application of water failed to bring the deep-seated fire under control, and on the following day the fire continued to burn, especially at the edges of the pile. The burning pile was finally extinguished by digging it out with a front-end loader and spraying each load with water. During this operation, there were occasional but intense flareups as the hot oil shale was exposed to air.

The overall effect of the four suppression trials with rubble fire 1 can be seen in table 3-2 and figure 3-13, which give the temperatures for each of the thermocouples just before and immediately after suppression. There was significant cooling of the shallow portions of the pile along the centerline. For example, thermocoup!e + dropped from an initial temperature of $907^{\circ}$ to $91^{\circ} \mathrm{C}$, while thermocouple 2 dropped from $854^{\circ}$ to $570^{\circ}$ ('. However, there was little effect on the deeper portions of the pile as shown by thermocouple 9 . Which rose from an initial value of $472^{\circ}$ to $524^{\circ}$ (". The nonuniformity of the application is illustrated by thermocouple 14 , which rose from an initial value of $144^{\circ}$ ( 10 a final value of $1,121^{\circ}$ (' during suppression activities, and by thermocouple 19. which fell from an initial value of $483^{\circ}$ 10 $202^{\circ} \mathrm{C}$. In any case, there were sufficient hot spots to account for the problems encountered in mucking out the pile.

During the course of rubble fire 1 , combustion gas samples were remotely collected by a strategically placed collecting tube attached to a vacuum pump. While the pile was burning, $C^{\circ} \mathrm{O}_{2}, \mathrm{C}^{\circ} \mathrm{O}$, and $\mathrm{H}$, averaged about $4,0.3$, and $0.5 \mathrm{pct}$, respectively. These values did not change significantly during the suppression atctivities. However, during the first application of water, the $\mathrm{H}_{2}$ level rose abruptly to $1.8 \mathrm{pet}$, giving indication of a watergats reaction. There was a momentary increase in the ( $\mathrm{O}_{2}$, level at this same time.

Table 3-2.-Temperatures just before and just after suppression activities for rubble fire 1

\begin{tabular}{|c|c|c|c|}
\hline \multirow[b]{2}{*}{ Station' } & \multicolumn{2}{|c|}{ Event temperatures. ${ }^{\circ} \mathrm{C}$} & \multirow{2}{*}{$\begin{array}{l}\text { Temperature difference } \\
\left(T_{1}-T_{1}\right) \cdot{ }^{\circ} \mathrm{C}\end{array}$} \\
\hline & $\begin{array}{c}\text { Initial } \\
\left(T_{1}\right)\end{array}$ & $\begin{array}{c}\text { Final } \\
\left(T_{1}\right)\end{array}$ & \\
\hline$\ldots \ldots \ldots$ & 27 & 30 & +3 \\
\hline$\ldots \ldots \ldots$ & 83 & 48 & -35 \\
\hline$\ldots \ldots \ldots$ & 854 & 610 & -244 \\
\hline$\ldots \ldots \ldots$ & 622 & 493 & -129 \\
\hline$\ldots \ldots \ldots$ & 907 & 91 & -816 \\
\hline$\ldots \ldots \ldots$ & NA & 223 & NA \\
\hline$\ldots$ & 679 & 742 & +63 \\
\hline$\ldots \ldots$ & 420 & 328 & -92 \\
\hline$\ldots$ & 529 & 307 & -222 \\
\hline$\ldots \ldots \ldots$ & 472 & 524 & +52 \\
\hline$\ldots \ldots \ldots \ldots$ & 258 & 250 & -8 \\
\hline$\ldots \ldots \ldots$ & 96 & 113 & +17 \\
\hline $12 \ldots \ldots$ & 536 & 313 & -223 \\
\hline $13 \ldots \ldots$ & 12 & 14 & +2 \\
\hline . . . . & 144 & 1.121 & +977 \\
\hline$\ldots \quad \ldots \ldots$ & 109 & 61 & -48 \\
\hline$\ldots \ldots \ldots$ & 360 & 353 & -7 \\
\hline$\ldots \ldots+\ldots$ & NA & NA & NA \\
\hline$\ldots \ldots \ldots$ & 532 & 90 & -442 \\
\hline 19 & 483 & 202 & -281 \\
\hline 20 & NA & NA & NA \\
\hline
\end{tabular}

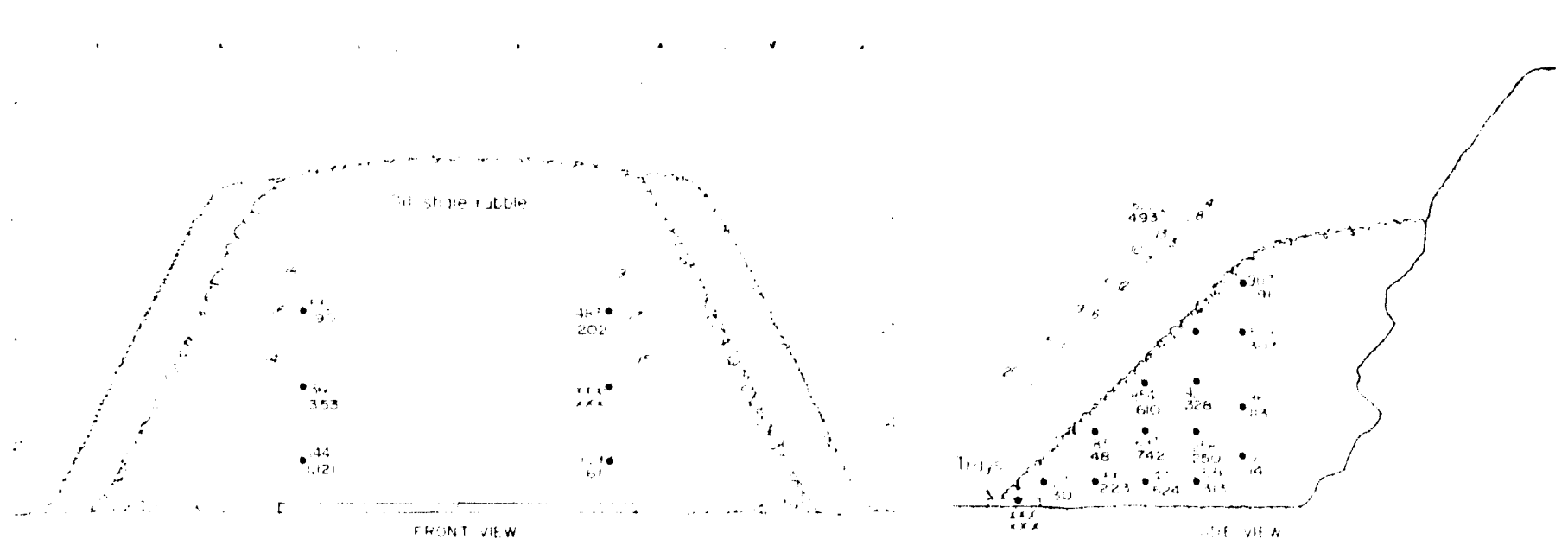

Figure 3-13.-Thermocouple readings before (top number) and after (bottom number) suppression activities with rubble fire 1. 


\section{RUBBLE FIRE 2}

Rubble pile 2, which involved ahout 65 tons of oil shate, was constructed around the electrically heated drum in order to simulate a spontaneous combustion event. This is shown in ligure $3-14$, along with the location of the 28 thermocouples used to monitor the temperatures of the pile and the drum. Since the purpose of the test was to simulate a slow, low. temperature heating, the initial voltage to the internal heaters was set below the maximum and voltage was increased three times during the test period, usually whenever stable temperatures were attained. The test ran for 508 h (21 days), during which time there were three major power outages totaling $50 \mathrm{~h}$ and 3.5 in of rainfall. Ambient temperatures ranged from $15^{\circ}$ to $29^{\circ}$ (. Eleven thermocouples (circled in figure 3-14) monitored the emperatures of the drum surfice and immediate surroundings daring the period.
The smoothed time-temperature trace for thermocouple 25. located on the top center of the drum, is shown in figute 3-15. This thermocouple measured the cemperature of the hottest region of the drum surface. As is evident in tigure 3-15, the surface temperature responded rapidly to increated power to the drum and then attained stable temperatures, ranging from $170^{\circ}$ to $255^{\circ} \mathrm{C}$, depending on the power level. The drum temperature fell rapidly when the power was interrupted. The temperature drop at $370 \mathrm{~h}$ was attributed to a 1.1 in rainfall. The temperature profiles for thermocouples 24 and 26 , located on the sides of the drum, were similar in shape. However, the maximum temperatures attained at a given power level were $45^{\circ}$ to $70^{\circ}$ C lower than those at the top eenter of the drum. The heat from the drum rose up and to the rear of the pile. Figure 3-16 shows the smoothed temperature profiles for thermocouples 10 and 15 , located 1 it above and 1 it behind the drum, respectively (see figure $3-14$ ). Features similar to

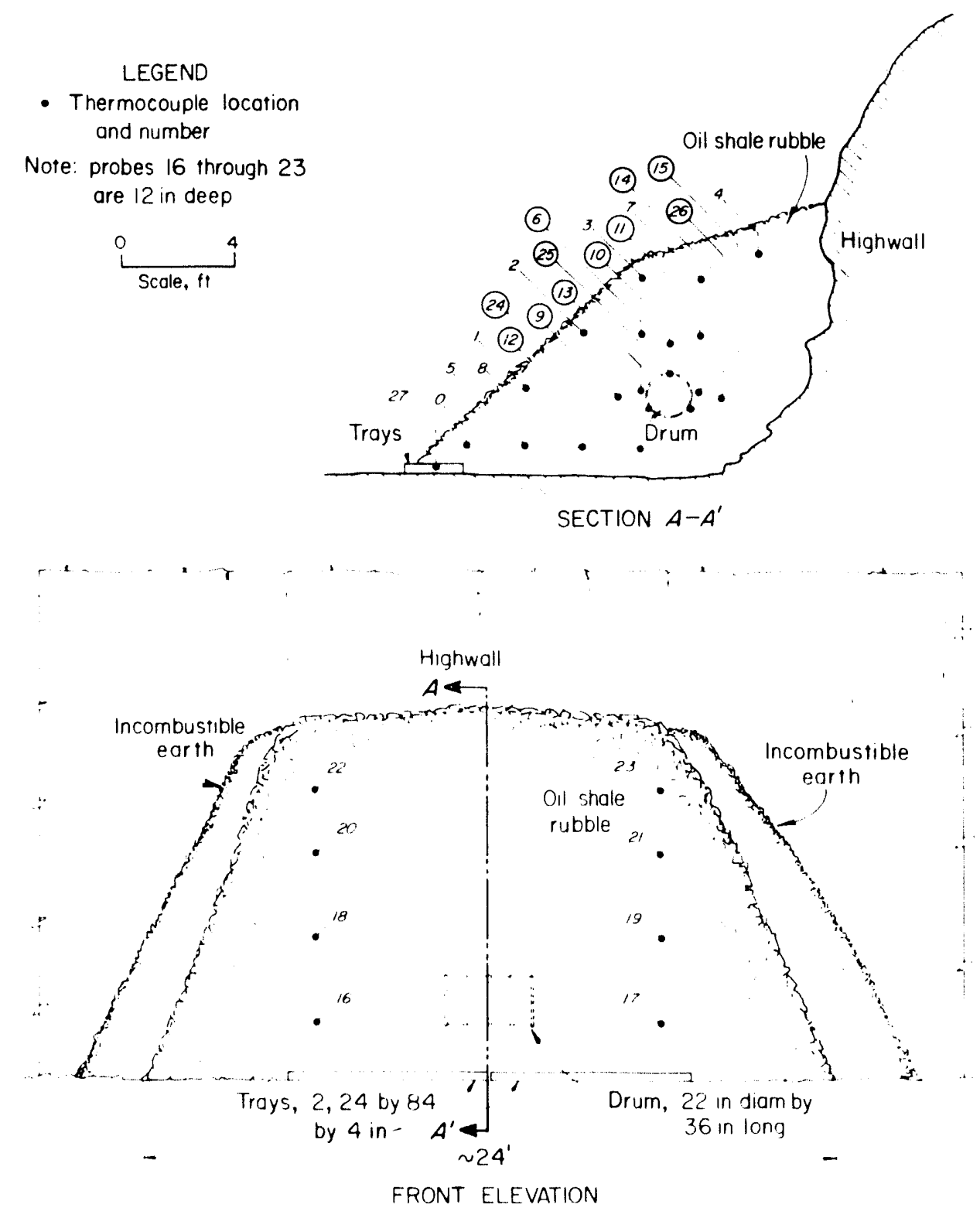

Figure 3-14.-Thermocouple locations for rubble fire 2. 


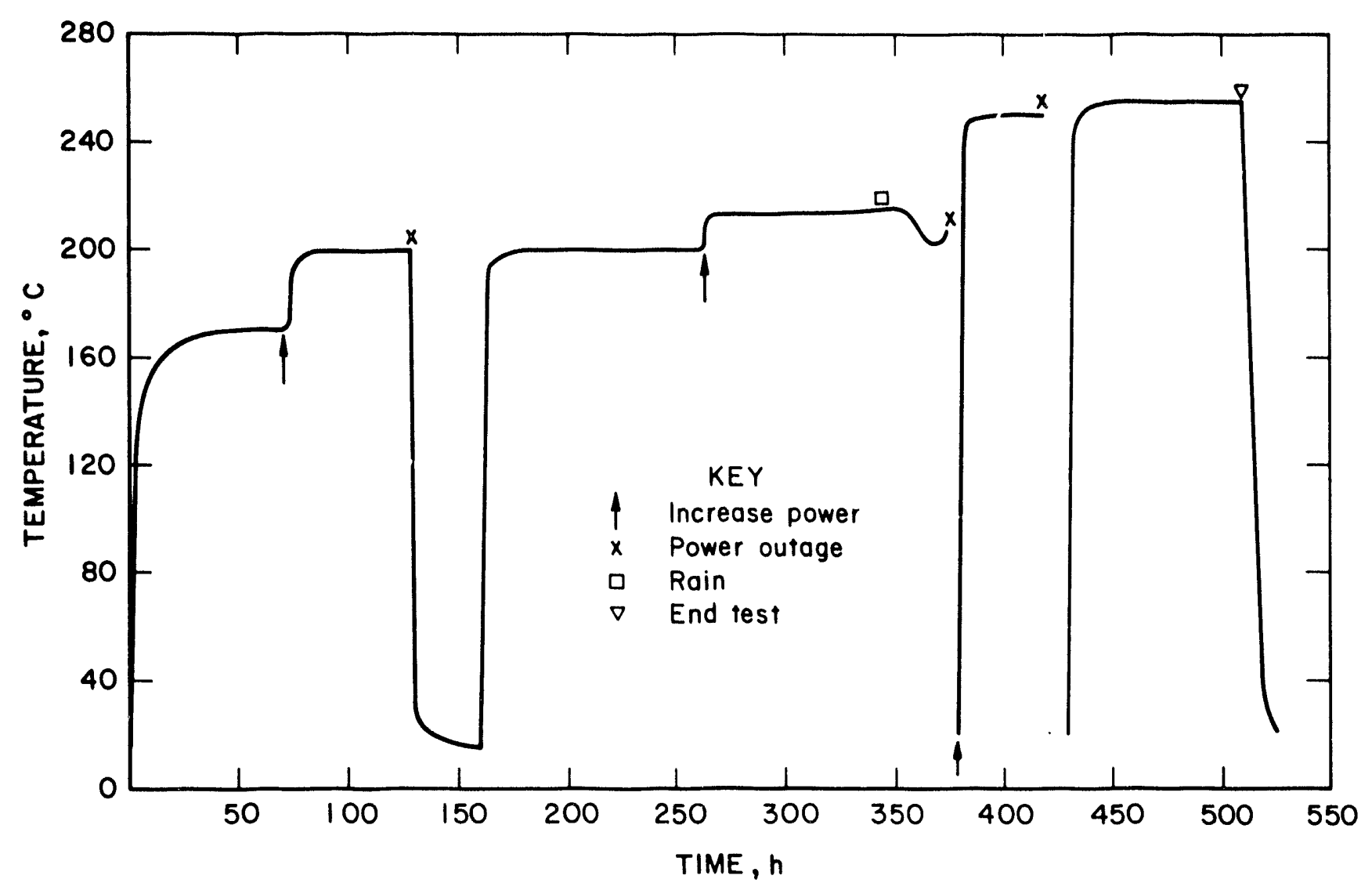

Figure 3-15.-Temperature history for thermocouple 25 in rubble fire 2.

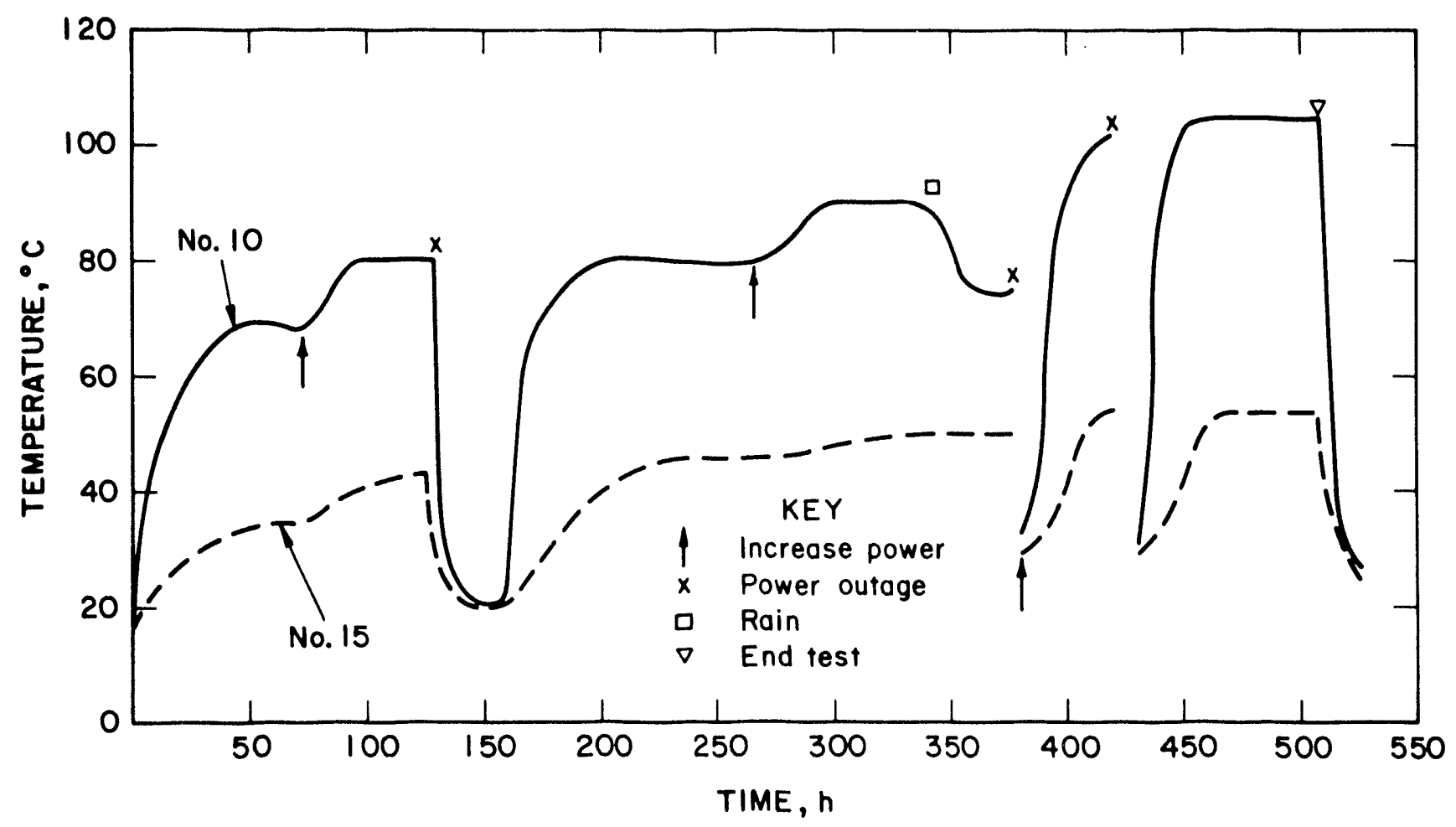

Figure 3-16. - Temperature history for thermocouples 10 and 15 in rubble fire 2. 
those in figure $3-15$ are obsious, but are not as sharp. Once again, stable temperatures were altained for the various drum power levels, as was the case for all monitored locations. The maximum stable temperatures at the various drum power levels for the thermocouples in the vicinity of the drum are summarized in table 3-3. The temperatures below and in front of the drum were lower than those above and to the rear. For example, at the highest power level, thermocouple 12 (below the drum) was not influenced by the drum and thermocouple 9 ( 1 ft in front of the drum) indicated only $27^{\circ}($, while 10 and 11 (above the drum) read about $10 \%)^{\circ}(\mathrm{a}$ and 15 (behind the drum) read $54^{\circ} \mathrm{C}$. The oil shale rubble in contact with the top surface of the drum reached a maximum stable temperature of about $255^{\circ}$ ( (thermocouple 25), which was matillained for 3 days before the end of the test. Stations 9 and 12 did not show an increase-apparently they malfunctioned.

A predictive capability developed by the Bureau to model spontaneous combustion in a fuel with an embedded heat source was utilied to project the temperature rise in the rubble pile. As shown in appendix $A$, an approximate agreement of predicted temperature with that for thermocouple 15 was achieved.

As shown by the temperature data, the heated drum did not innte the rubble pile, nor were there any indications that the shale near the drum underwent exothermic oxidation reactions. Smoke and or vapors were not observed, and there "as no odor. At the highest power level, a circular area, about $1 \mathrm{ft}(30.5 \mathrm{~cm})$ in dianeter on the surface of the pile above the drum, was warm to the louch and generated a warm airflow. The rapid drop in the temperatures of the drum and surrounding shale due to power outages and termination of power at the end of the test indicated substantial heat loss from the pile.

In order to include the second pile of oil shale rubble in the suppression tests, the pile was finally ignited using 20 gal
(75.7 I.) of diesel fuel with a small quantity of gasoline added to facilitate ignition of the diesel fuel. This ignition tan be seen in figure 3-17. The start of this fire was more intense than that of the first pile, because of the use of gasoline to accelerate ignition and burning of the diesel fuel. After starting, the fire (fig. 3-18) seemed to spread over the surface at a slower rate than in the first burn and did not seem to burn as violently as the first one, most likely because of the greater abundance of fines throughout the pile and on much of the surface. During this burn, sporadic winds developed. Hence, the burn was not steady and failed to sustain high propagation velocities as did the first fire. The heat zone and flame front advanced fairly rapidly up the eenterline, where the greater number of thermocouples were located, probably because this section of the pile contained lewer fines. As the lite progressed, 3- 10 4 -ft-long flames were driven at times by winds from the west at speeds up to and occatsionally over $750 \mathrm{~h} / \mathrm{min}(228 \mathrm{~m} / \mathrm{min})$. There appeared to be considerably more smoke given off during this burn than in the previous one.

The surface and horizontal velocities of the leading edge of the combustion wave are shown in ligure $3-19$. The surface velocity went from $4.0 \mathrm{ft} / \mathrm{h}(122 \mathrm{~cm} / \mathrm{h}), \mathrm{to}(0.53 \mathrm{ft} / \mathrm{h}(16 \mathrm{~cm} / \mathrm{h})$, and then $100.34 \mathrm{ft} / \mathrm{h}(11 \mathrm{~cm} / \mathrm{h})$. The initial high velocity is associated with the burning of the diesel fuel. The horizontal velocity went from $0.53 \mathrm{ft} / \mathrm{h}(16 \mathrm{~cm} / \mathrm{h})$ to $0.32 \mathrm{ft} / \mathrm{h}(10.4$ $(\mathrm{m} / \mathrm{h})$ as the combustion wave stabilized.

Extinguishment started $25 \mathrm{~h}$ and $20 \mathrm{~min}(1.520 \mathrm{~min})$ after the fire was ignited. As indicated in table 3-4, three different applications of foam were used, and at limes two foam generators were used (fig. 3-20). However, intermittent water pump problems necessitated cutting back to one foam generator on occasion. The first application of foam lasted about 40 min and employed Ansulite, a 6-pet concentration of aqueous film-forming foam (AFFF) in water. For the first $20 \mathrm{~min}$, the

Table 3-3.-Slow-heating test data

\begin{tabular}{|c|c|c|c|c|c|c|c|c|c|c|c|c|}
\hline \multirow{2}{*}{$\begin{array}{l}\text { Time.' } \\
\text { h (days) }\end{array}$} & \multirow{2}{*}{$\begin{array}{c}\text { Power } \\
\text { W }\end{array}$} & \multicolumn{11}{|c|}{ Maximum temperature. ${ }^{\circ} \mathrm{C}$ at thermocouple station ${ }^{3}-$} \\
\hline & & 6 & 9 & 10 & 11 & 12 & 13 & 14 & 15 & 24 & 25 & 26 \\
\hline $72(3)$ & 2.400 & 29 & 20 & 68 & 60 & 15 & 60 & 80 & 34 & 117 & 170 & 125 \\
\hline $264(11)$ & 2.800 & 31 & 25 & 80 & 81 & 17 & 68 & 96 & 46 & 138 & 200 & 200 \\
\hline $336(14)$ & 3.100 & 32 & 21 & 91 & 85 & 15 & 71 & 102 & 50 & 150 & 215 & 215 \\
\hline $508(21)$ & 4.000 & 36 & 27 & 105 & 102 & 16 & 87 & 125 & 54 & 184 & 255 & 255 \\
\hline
\end{tabular}

Table 3-4.-Summary of suppression trials for rubble fire 2

\begin{tabular}{|c|c|c|c|c|c|}
\hline \multirow[b]{2}{*}{ Trial } & \multicolumn{2}{|l|}{ Extınguishant } & \multicolumn{2}{|c|}{ Application } & \multirow[b]{2}{*}{ Results } \\
\hline & Foam lvise & $\begin{array}{c}\text { Quantity. } \\
\text { gal }\end{array}$ & $\begin{array}{c}\text { Tıme: } \\
\text { min }\end{array}$ & $\begin{array}{c}\text { Duration, } \\
\text { min }\end{array}$ & \\
\hline \multirow[t]{2}{*}{1} & Ansulite $(3 \mathrm{pct})$ & 2.700 & 1.520 & 20 & $\begin{array}{l}\text { Significant drop in average pile temperature, } \\
\text { no strong tendency to reheat. }\end{array}$ \\
\hline & Ansulite (1 pct) & 2.530 & 1.540 & 20 & \\
\hline 2 & Protein $(6 \mathrm{pct})$ & 160 & 1.570 & 13 & Insignificant effect but good foam blanket. \\
\hline 3 & $\begin{array}{l}50 / 50 \text { medium-expansion and } \\
\text { Ansulite }(2 \mathrm{pcl})\end{array}$ & 1.020 & 1.620 & 35 & Significant drop in average pile temperature. \\
\hline
\end{tabular}

To convert galions to liters. multiply by 3785

i From start of fire 


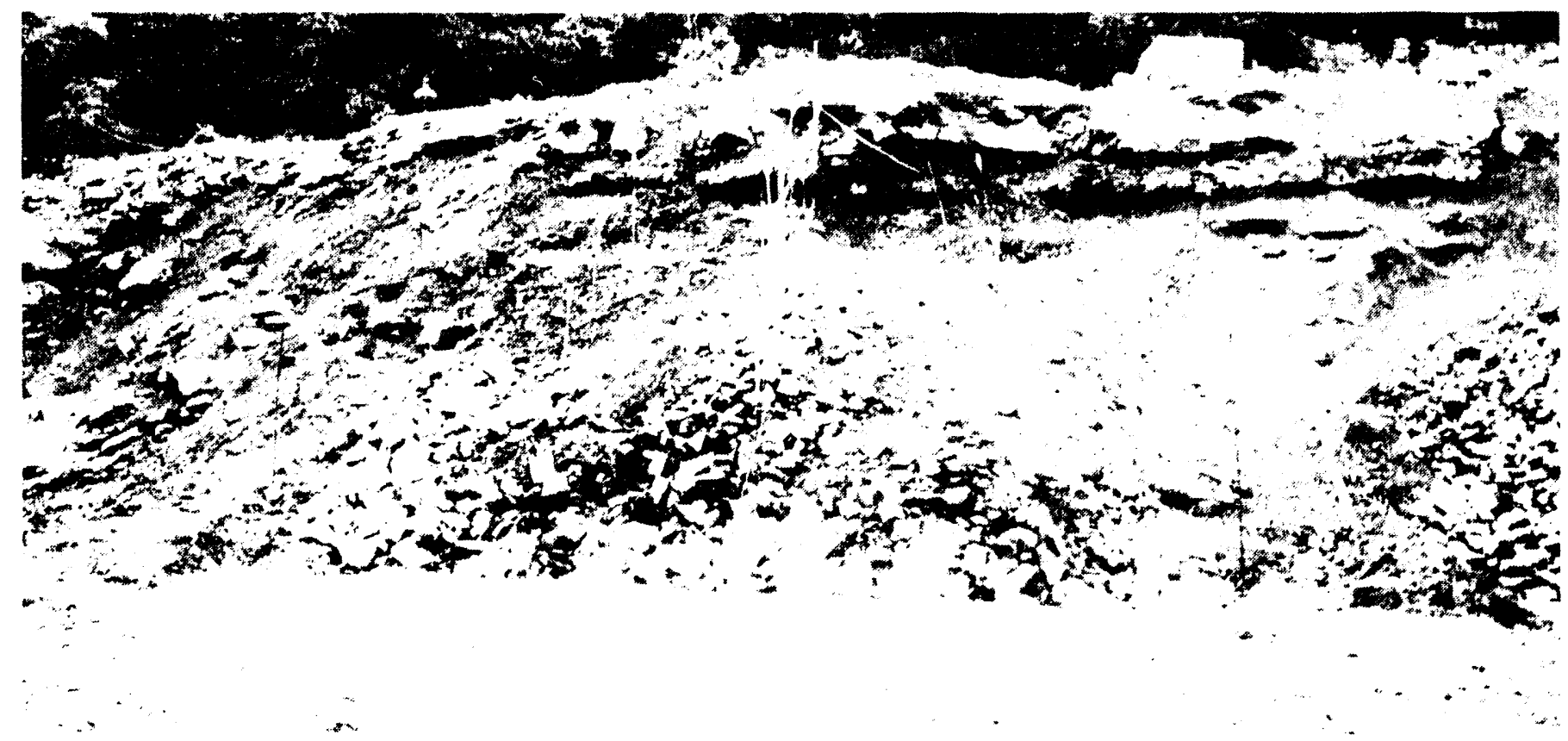

Figure 3-17.-Ignition of rubble fire 2 with diesel fuel.

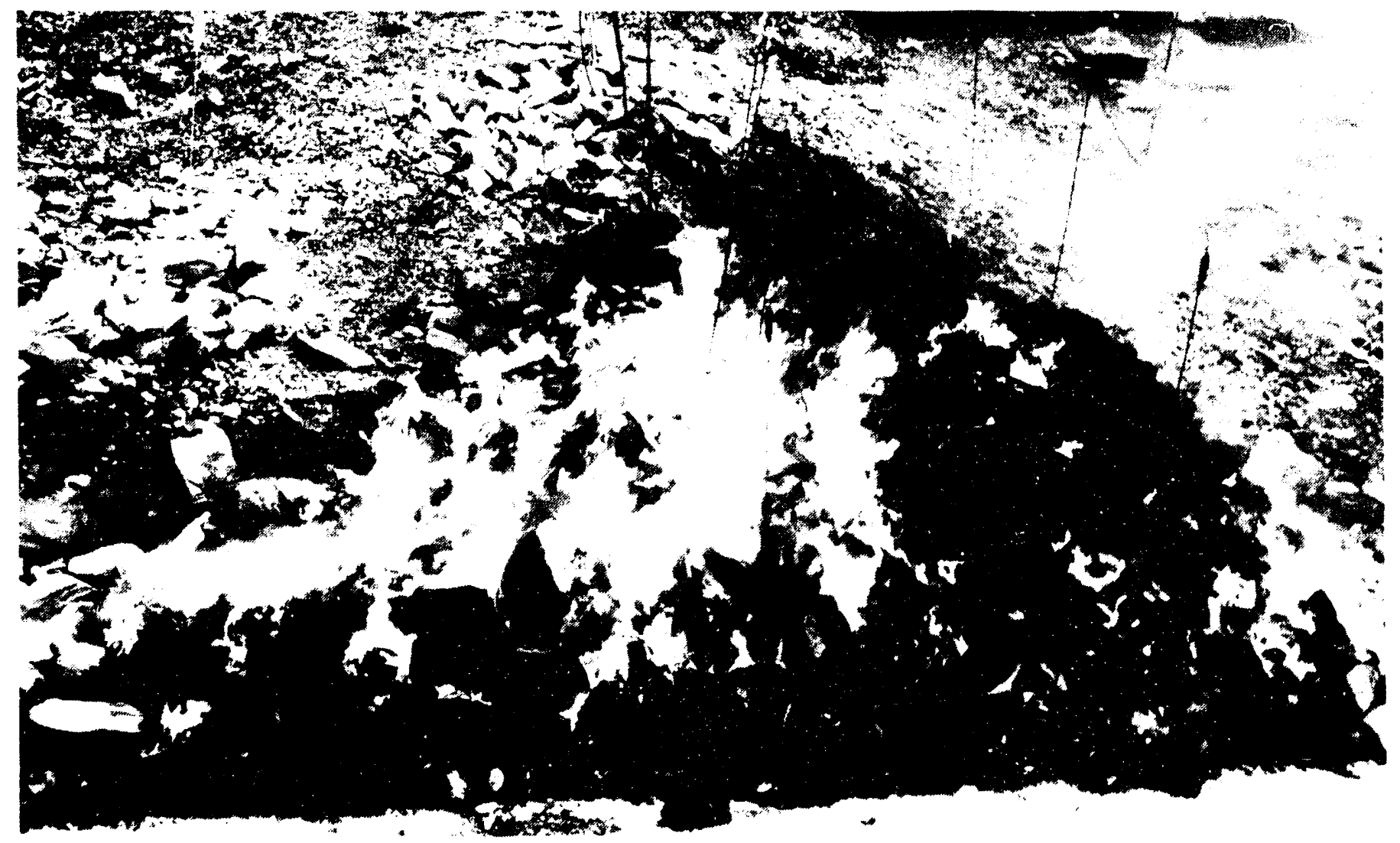

Figure 3-18. - Surface flame advance in rubble fire 2. 


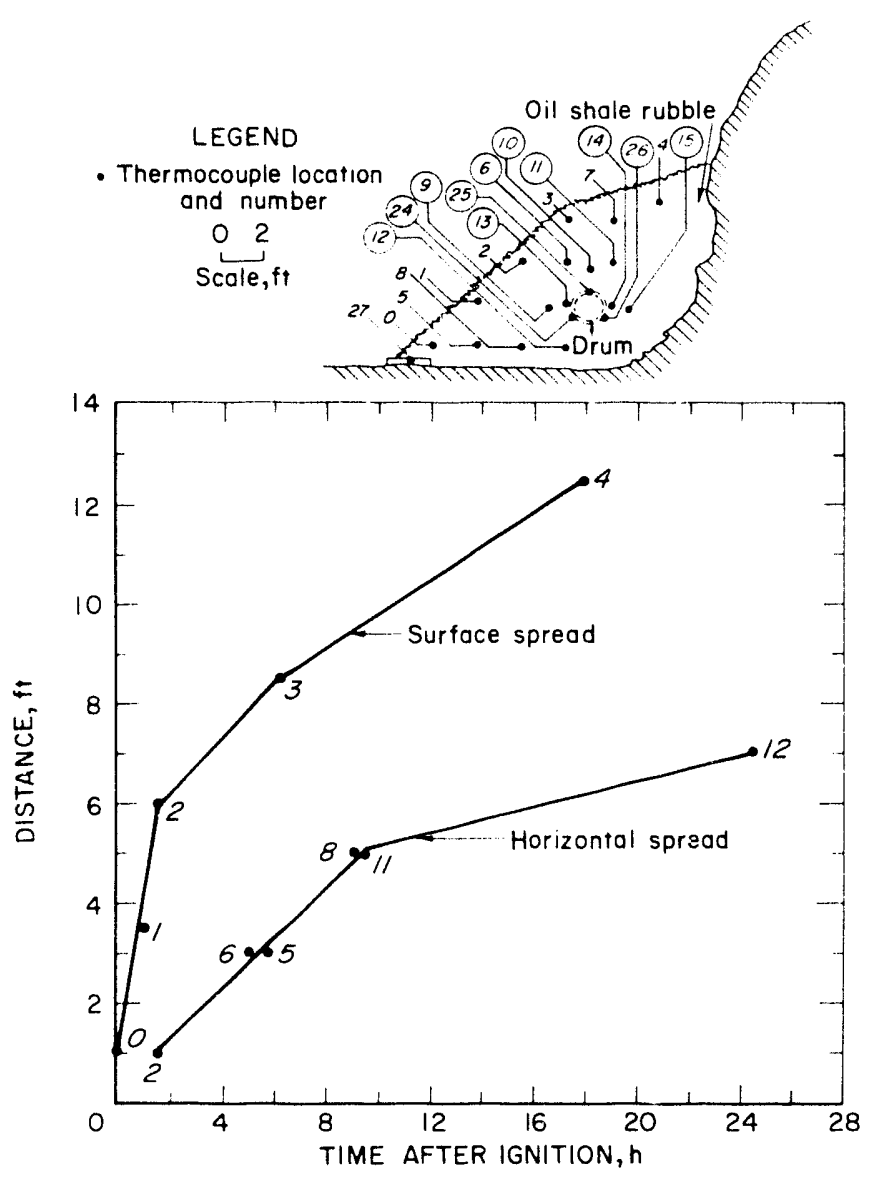

Figure 3-19.-Advance of leading edge of combustion wave in rubble fire 2 . proportioning was 3 parts Ansulite and 97 parts water; for the remaining $20 \mathrm{~min}$, the proportion was cut to 1 part Ansulite and 99 parts water. The $40-\mathrm{min}$ application consumed $130 \mathrm{gal}$ $(492 \mathrm{~L})$ of Ansulite and 5,100 gal $(19,304 \mathrm{~L})$ of water. A lasting foam blanket could not be maintained with either the 3- or 1-pct Ansulite mixtures.

Application of the Ansulite foam resulted in a very significant reduction in average pile temperature, as shown in figure 3-21. This, of course, is associated with the large quantity of water used in this trial.

A 3-pct protein concentrate was used for the second foam application, which lasted for about $13 \mathrm{~min}$. The proportioning was 6 parts concentrate and 94 parts water, which consumed 10 gal $(37.9 \mathrm{~L})$ of concentrate and $150 \mathrm{gal}(568 \mathrm{~L})$ of water. As indicated in figure 3-21, this application had an insignificant effect on average pile temperature. The high-protein foam did, however, produce a well-consolidated foam blanket that maintained its integrity for about $15 \mathrm{~min}$, a reasonable period of time. It adhered to the highwall to a greater degree than the foams used in rubble fire 1 .

The third application of foam utilized a 50/50 mixture of a medium-expansion foam and Ansulite, which was proportioned 2 parts of mixture and 98 parts water. This was applied for 35 min to maintain the foam cover and consumed 20 gal $(75.7 \mathrm{~L})$ of the $50 / 50 \mathrm{mix}$ and $1,000 \mathrm{gal}(3,785 \mathrm{~L})$ of water. As indicated in figure 3-21, this application resulted in another significant drop in average pile temperature. However, after the foam had dissipated, which took about $2 \mathrm{~min}$, the temperatures around the edges of the pile began to rise slowly. The following day, the edges of the pile were sprayed with water for about $20 \mathrm{~min}$. The pile was mucked out with a front-end loader, preventing flare-ups. Temperatures at the various thermocouple locations just before and immediately after suppression activities are given in table 3-5 and figure 3-22. All of the thermocouples, even the deepest ones, registered temperatures below $100^{\circ} \mathrm{C}$, which indicates a suciessful quench.

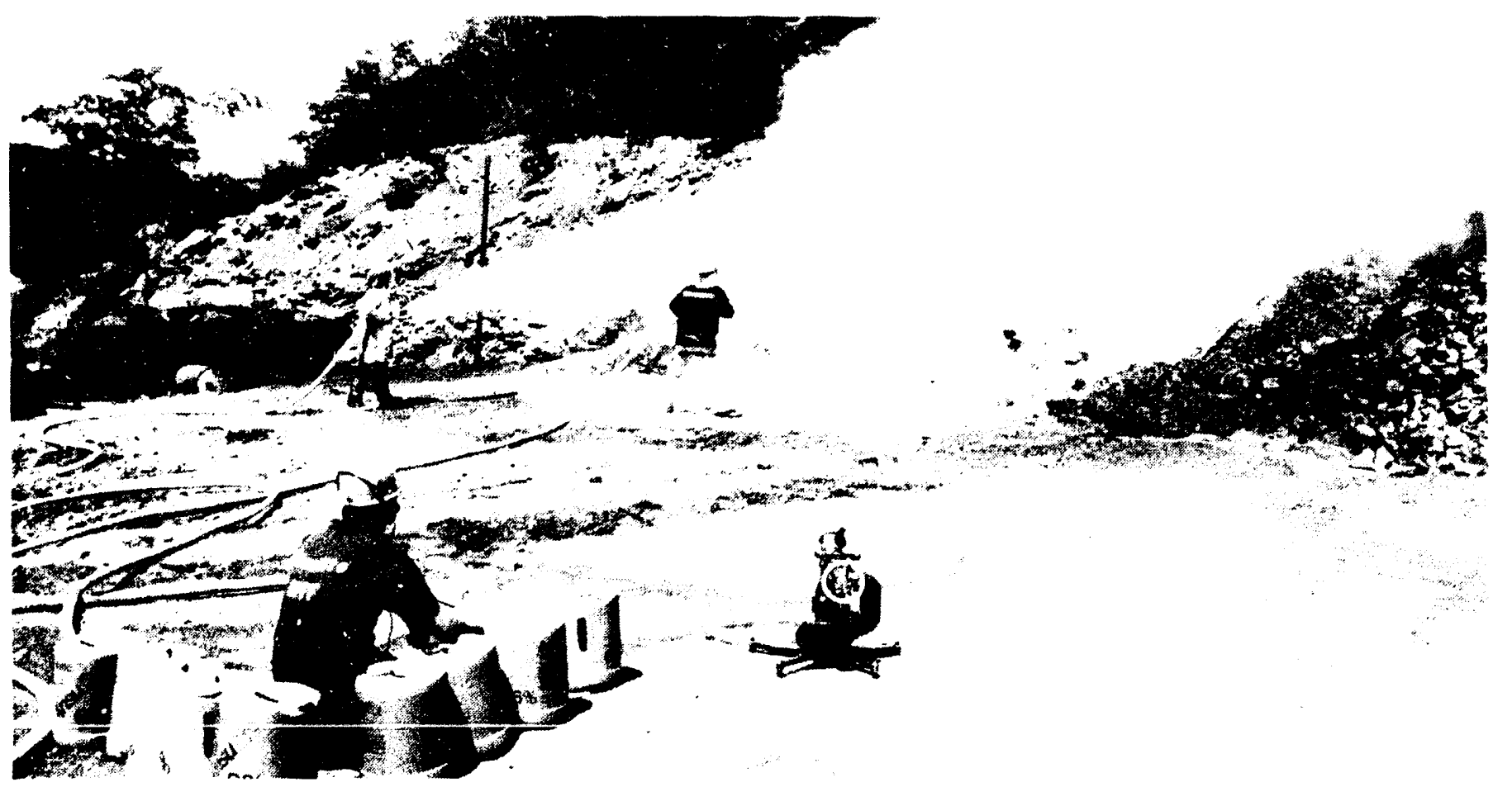

Figure 3-20.-Use of two foam generators on rubble fire 2. 
Combustion gas samples collected from this fire showed a predominance of normal air constituents, with a drop in oxygen content and corresponding increase in $\mathrm{CO}_{2}$ as the fire progressed. As in the case of rubble fire 1 , there was a significant but short-lived rise in the level of hydrogen experienced during the first foam-water application, indicative of a water-gas reaction.

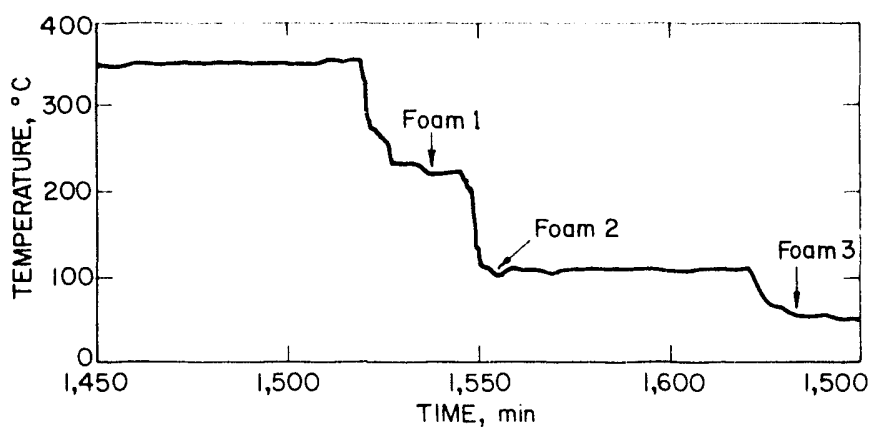

Figure 3-21.-Average pile temperature as a function of time for rubble fire 2 .
Table 3-5.-Temperatures just before and just after suppression activities for rubble fire 2

\begin{tabular}{|c|c|c|c|}
\hline \multirow[b]{2}{*}{ Station ${ }^{1}$} & \multicolumn{2}{|c|}{ Event temperatures, ${ }^{\circ} \mathrm{C}$} & \multirow{2}{*}{$\begin{array}{c}\text { Temperature difference } \\
\left(T_{1}-T_{1}\right),{ }^{\circ} \mathrm{C}\end{array}$} \\
\hline & $\begin{array}{c}\text { Initial } \\
\left(T_{1}\right)\end{array}$ & $\begin{array}{c}\text { Final } \\
\left(T_{1}\right)\end{array}$ & \\
\hline $0 \ldots \ldots \ldots \ldots \ldots \ldots$ & 39 & 33 & -6 \\
\hline $1 \ldots \ldots \ldots \ldots \ldots \ldots$ & 167 & 23 & -144 \\
\hline $2 \ldots \ldots \ldots \ldots \ldots \ldots$ & 502 & 18 & -484 \\
\hline 3...................... & 182 & 19 & -163 \\
\hline $4 \ldots \ldots \ldots \ldots \ldots \ldots$ & 181 & 34 & -157 \\
\hline $5 \ldots \ldots \ldots \ldots \ldots \ldots$ & 282 & 35 & -26 \\
\hline $6 \ldots \ldots \ldots \ldots \ldots \ldots$ & 535 & 24 & -511 \\
\hline $7 \ldots \ldots \ldots \ldots \ldots \ldots$ & 494 & 29 & -465 \\
\hline $8 \ldots \ldots \ldots \ldots \ldots \ldots$ & 467 & 45 & -422 \\
\hline $9 \ldots \ldots \ldots \ldots \ldots \ldots$ & 562 & 41 & -521 \\
\hline $10 \ldots \ldots \ldots \ldots \ldots \ldots$ & 284 & 63 & -221 \\
\hline $11 \ldots \ldots \ldots \ldots \ldots \ldots$ & 149 & 81 & -68 \\
\hline $12 \ldots \ldots \ldots \ldots \ldots \ldots$ & 32 & 62 & +30 \\
\hline $13 \ldots \ldots \ldots \ldots \ldots \ldots$ & 519 & 41 & -478 \\
\hline $14 \ldots \ldots \ldots \ldots \ldots \ldots$ & 140 & 83 & -57 \\
\hline $15 \ldots \ldots \ldots \ldots \ldots \ldots$ & 84 & 85 & +1 \\
\hline $16 \ldots \ldots \ldots \ldots \ldots \ldots$ & 935 & 96 & -839 \\
\hline $17 \ldots \ldots \ldots \ldots \ldots \ldots$ & 318 & 66 & -252 \\
\hline $18 \ldots \ldots \ldots \ldots \ldots$ & 169 & 23 & -137 \\
\hline $19 \ldots \ldots \ldots \ldots \ldots$ & 349 & 84 & -265 \\
\hline $20 \ldots \ldots \ldots \ldots \ldots$ & 231 & 21 & -210 \\
\hline
\end{tabular}

See figure 3-14 for thermocouple locations
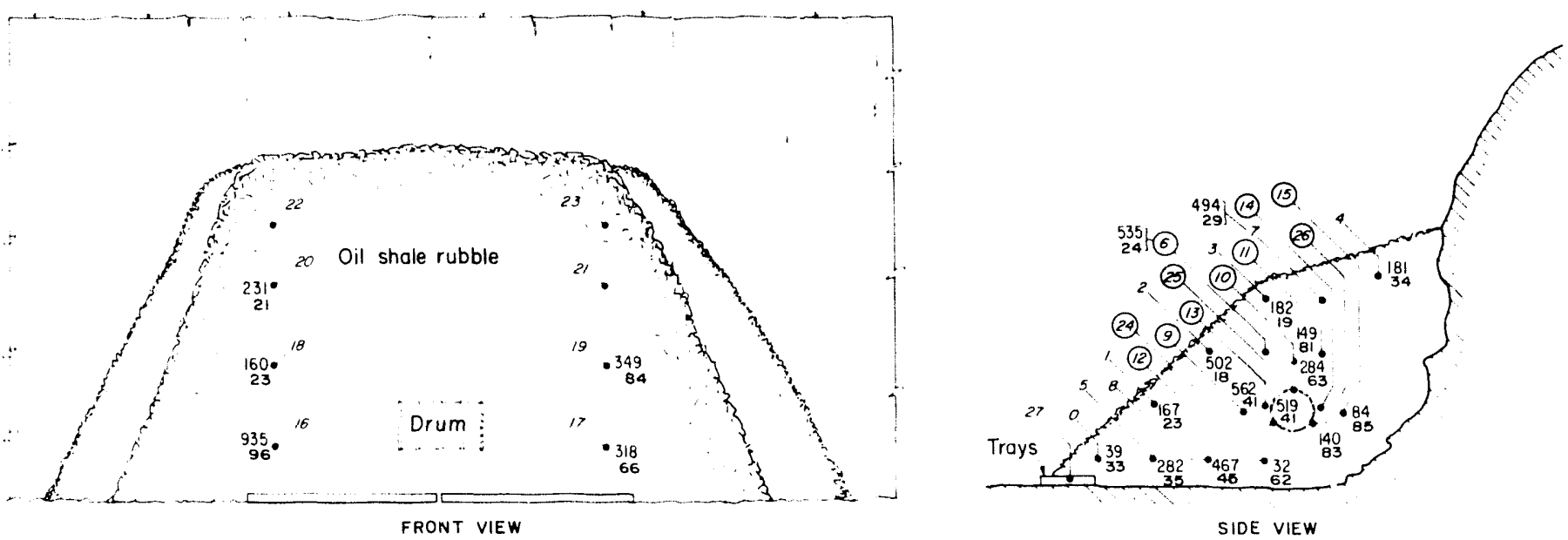

Figure 3-22.-Thermocouple readings before (top number) and after (bottom number) suppression activities with rubble fire 2. 


\section{RUBBLE FIRE 3}

Rubble pile 3 consisted of unburned shale from a previous burn blended with fresh raw shale. The total amount of shale was about 20 tons. The unburned shale from the previous test was screened through a 3 - by 4 -in $(7.6-$ by $10.2-\mathrm{cm})$ screen to remove debris and other inert fines. Thus, the pile contained predominantly coarse oil shale, providing numerous air passages throughout. The shale was stacked to a height of $7 \mathrm{ft}$ $(2.13 \mathrm{~m})$, and the distance from the toe to the highwall was about $10 \mathrm{ft}(3 \mathrm{~m})$. Nine thermocouples were placed at 1 - and 2-ft $(30.5-$ and $61-\mathrm{cm})$ depths at $2-\mathrm{ft}(61-\mathrm{cm})$ intervals along the centerline. Two sets of three additional thermocouples were placed $1 \mathrm{ft}(30.5 \mathrm{~cm})$ deep and $5 \mathrm{ft}(1.52 \mathrm{~m})$ to either side of the centerline as shown in figure 3-23.

Rubble fire 3 was ignited with $20 \mathrm{gal}(75.7 \mathrm{~L})$ of diesel fuel placed in two trays at the toe of the pile. A small amount of gasoline was added to the diesel fuel to facilitate ignition, which was accomplished with electric matches together with a small amount of black powder in plastic pouches. The fire was allowed to develop for $5 \mathrm{~h}$ before the suppression exercise commenced. The surface and horizontal velocities of the
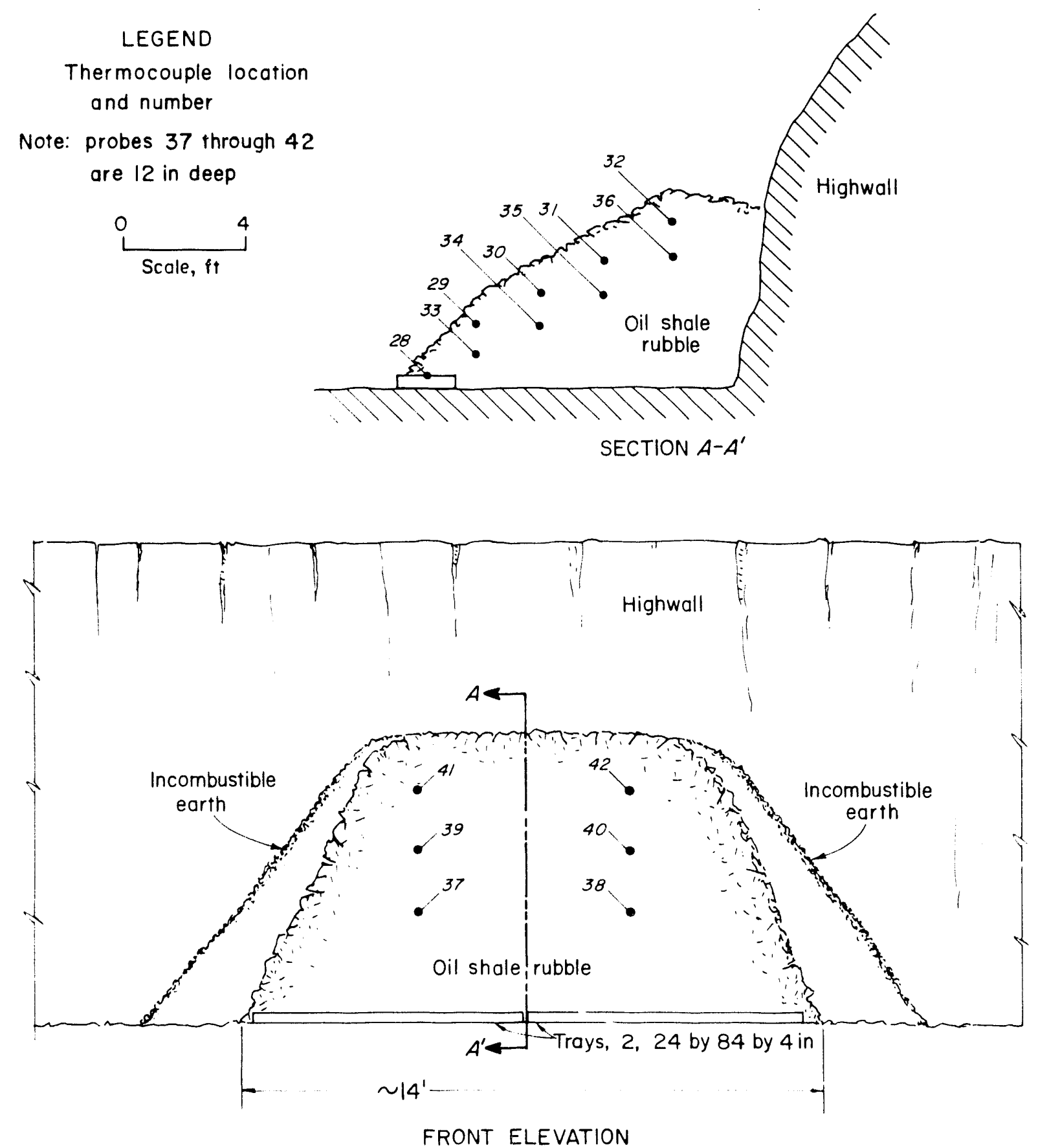

Figure 3-23.-Thermocouple locations for rubble fire 3. 
leading edge of the combustion wave are shown in figure 3-24. The surface velocity was approximately $0.4 \mathrm{ft} / \mathrm{h}(12.2 \mathrm{~cm} / \mathrm{h})$ for several hours after ignition and then changed abruptly to about $6 \mathrm{ft} / \mathrm{h}(1.83 \mathrm{~m} / \mathrm{h})$ prior to extinguishment. The horizontal velocity stabilized at $0.5 \mathrm{ft} / \mathrm{h}(15.2 \mathrm{~cm} / \mathrm{h})$ and remained constant throughout the test. The abrupt change in the surface velocity is unexplained.

Five hours after pile 3 was ignited, water was applied to determine if water alone could extinguish the fire before it became deep seated. A total of $1,750 \mathrm{gal}(6,624 \mathrm{~L})$ of water was applied in about $25 \mathrm{~min}$. During this exercise, the average pile temperature dropped from in excess of $260^{\circ} \mathrm{C}$ to approximately $75^{\circ} \mathrm{C}$ and continued to decline, indicating a successful extinguishment (fig. 3-25).

Thermocouple readings just before and immediately after the application of water to rubble fire 3 are shown in table 3-6 and figure 3-26. It should be noted that all thermocouples displayed temperatures below $100^{\circ} \mathrm{C}$ after the application of water, which indicated a successful quench. The combustion gas analysis showed no significant departures from the normal composition of air except for small quantities of $\mathrm{CO}$ and $\mathrm{CO}_{2}$.

Table 3-6. - Temperatures just before and just after suppression activities for rubble fire 3

\begin{tabular}{|c|c|c|c|}
\hline \multirow[b]{2}{*}{ Station' } & \multicolumn{2}{|c|}{ Event temperature, ${ }^{\circ} \mathrm{C}$} & \multirow{2}{*}{$\begin{array}{l}\text { Temperature difference } \\
\qquad\left(T_{1}-T_{1}\right),{ }^{\circ} \mathrm{C}\end{array}$} \\
\hline & $\begin{array}{c}\text { Initial } \\
\left(T_{1}\right)\end{array}$ & $\begin{array}{c}\text { Final } \\
\left(T_{1}\right)\end{array}$ & \\
\hline 28. & NA & NA & NA \\
\hline $29 \ldots \ldots \ldots \ldots \ldots \ldots$ & 659 & 89 & -570 \\
\hline $30 \ldots \ldots \ldots \ldots \ldots$ & 129 & 94 & -35 \\
\hline $31 \ldots \ldots \ldots \ldots \ldots$ & 65 & 83 & +18 \\
\hline $32 \ldots \ldots \ldots \ldots \ldots \ldots$ & 21 & 69 & +48 \\
\hline $33 \ldots \ldots \ldots \ldots \ldots$ & 672 & 97 & -575 \\
\hline $34 \ldots \ldots \ldots \ldots \ldots$ & 65 & 77 & +12 \\
\hline $35 \ldots \ldots \ldots \ldots \ldots$ & 38 & 72 & -34 \\
\hline ............. & 23 & 69 & +46 \\
\hline 37. & 552 & 86 & -466 \\
\hline .......... & 422 & 91 & -331 \\
\hline $39 \ldots \ldots \ldots \ldots \ldots$ & 789 & 74 & -715 \\
\hline $40 \ldots \ldots \ldots \ldots \ldots$ & 67 & 93 & +26 \\
\hline $41 \ldots \ldots \ldots \ldots \ldots$ & 24 & 37 & +13 \\
\hline $42 \ldots \ldots \ldots \ldots \ldots$ & 24 & 57 & +33 \\
\hline
\end{tabular}

LEGEND

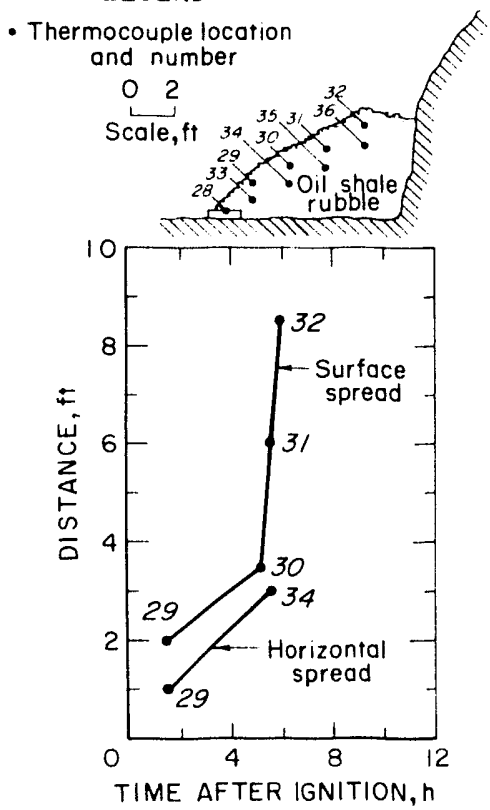

Figure 3-24.-Advance of leading edge of combustion wave in rubble fire 3 .

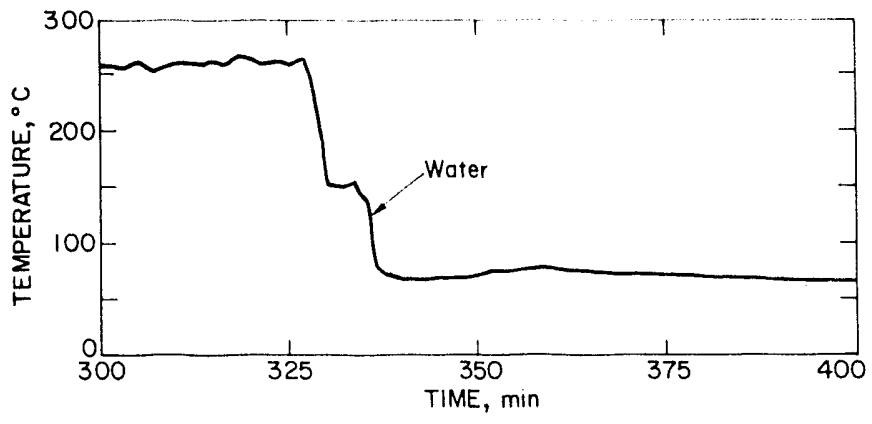

Figure 3-25.-Average pile temperature as a function of time for rubble fire 3 .
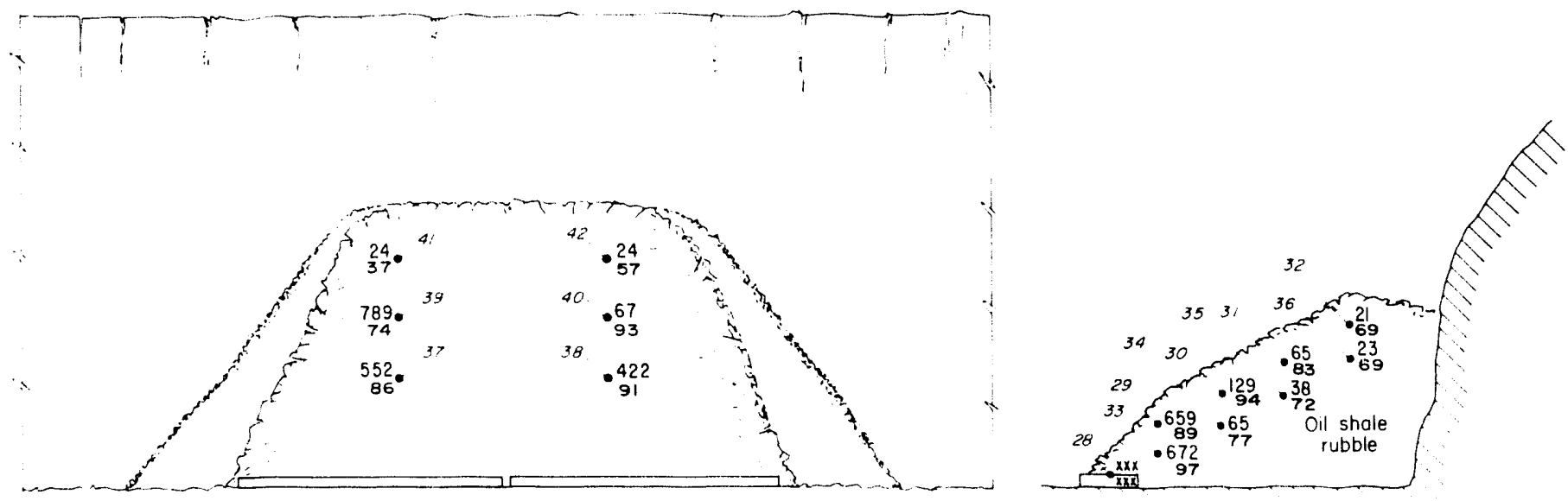

FRUNT VIEW

Sier ViE

Figure 3-26.-Thermocouple readings before (top number) and after (bottom number) suppression activities with rubble fire 3. 


\section{RUBBLE FIRE 4}

Rubble pile 4 , which contained approximately 85 tons of shale, was constructed in a manner similar to pile 1 . It contained a substantial quantity of fines, which, for the most part, were localized near the center of the pile. The dimensions of the pile and thermocouple layout are shown in figure 3-27. A total of 27 thermocouples were used to monitor the fire and extinguishment exercise. The greatest concentration of thermocouples was along the centerline, from $1 \mathrm{ft}(30.5 \mathrm{~cm})$ off the bottom to within $1 \mathrm{ft}(30.5 \mathrm{~cm})$ below the surface. Four additional thermocouples were placed on either side, $4 \mathrm{ft}$ ( 122 $\mathrm{cm}$ ) from the centerline and $1 \mathrm{ft}(30.5 \mathrm{~cm})$ below the surface.

The pile was ignited with $20 \mathrm{gal}(75.7 \mathrm{~L})$ of diesel fuel in two trays at the toe of the pile. A small amount of gasoline was added to the diesel fuel to facilitate ignition, which was accomplished with electric matches in small pouches of black powder.

For the first two burns, the wind had been predominantly from the southeast. However, on the morning of the fourth ignition the wind had shifted to the east-southeast and remained such for the most of the day. Wind velocity ranged from about $50 \mathrm{ft} / \mathrm{min}(15.2 \mathrm{~m} / \mathrm{min})$ to about $450 \mathrm{ft} / \mathrm{min}(137$ $\mathrm{m} / \mathrm{min}$ ). The fire was allowed to burn for about $24-1 / 2 \mathrm{~h}$ before extinguishment began. The surface and horizontal velocities of the leading edge of the combustion wave are shown in figure $3-28$. The surface velocity was constant at about $2.2 \mathrm{ft} / \mathrm{h}(67$ $\mathrm{cm} / \mathrm{h}$ ) for the first few hours of the burn, while the horizontal velocity was about $0.5 \mathrm{ft} / \mathrm{h}(15.2 \mathrm{~cm})$ during the first $12 \mathrm{~h}$ and then dropped to about $0.3 \mathrm{ft} / \mathrm{h}(9.1 \mathrm{~cm} / \mathrm{h})$ for the next $12 \mathrm{~h}$.

The extinguishment procedure for this fire was to apply a foam that was generated with water containing a soluble extinguishing agent. For this purpose, $550 \mathrm{lb}(24.9 \mathrm{~kg})$ of diammonium phosphate (DAP) was dissolved in 750 gal $(2,839$ L) of water to form a 9-pct DAP solution. Six hundred gallons $(2,271 \mathrm{~L})$ of the DAP solution and 30 gal $(113.6 \mathrm{~L})$ of MSA Ultrafoam concentrate were then applied to the fire over a 1.5-h period. The MSA Ultrafoam, a low-expansion foam designed for use with salt water, had previously been demonstrated to work satisfactorily with the DAP solution. It formed a reasonably well-integrated blanket that showed little tendency to run off and lasted about $7 \mathrm{~min}$ after the final application.

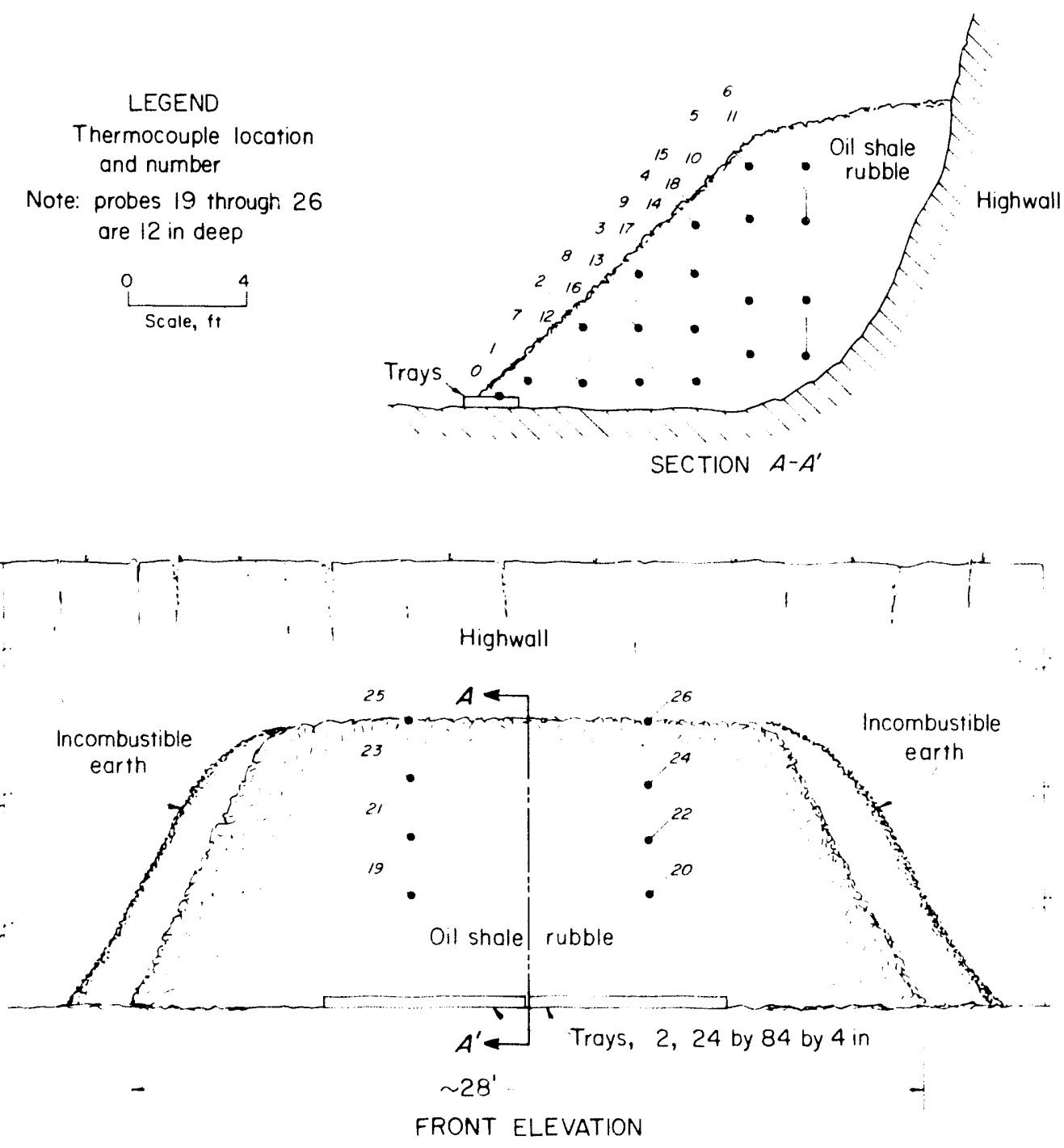

Figure 3-27.-Thermocouple locations for rubble fire 4. 
Following the application of the extinguishant, the fire appeared to be under control. However, the next morning there were still some flames issuing from the left side of the pile. The fire continued to smolder until it was dug out. During the digging, there was no instance of flareup as in the case of rubble fire 1 .

The average pile temperature given in figure 3-29 showed a significant drop associated with the application of the DAP-Ultrafoam combination. However, the average residual temperature was approximately $200^{\circ} \mathrm{C}$, which was high enough to promote the reignition that was noted above.

The thermocouple readings before and after the application of the DAP-foam combination are given in table 3-7 and figure 3-30. Residual temperatures were in excess of the average value shown in figure 3-30, especially along the centerline of the middle of the pile. Analysis of the combustion gases collected from rubble fire 4 showed no significant increase in hydrogen during the extinguishment activities.

Table 3-7.-Temperatures just before and just after suppression activities for rubble fire 4

\begin{tabular}{|c|c|c|c|}
\hline \multirow[b]{2}{*}{ Station : } & \multicolumn{2}{|c|}{ Event temperatures, ${ }^{\circ} \mathrm{C}$} & \multirow{2}{*}{$\begin{array}{l}\text { Temperature difference } \\
\qquad\left(T_{1}-T_{1}\right),{ }^{\circ} \mathrm{C}\end{array}$} \\
\hline & $\begin{array}{l}\text { Initial } \\
\left(T_{1}\right)\end{array}$ & $\begin{array}{c}\text { Final } \\
\left(T_{1}\right)\end{array}$ & \\
\hline 다. & 26 & 125 & +99 \\
\hline $1 \ldots \ldots \ldots \ldots \ldots \ldots \ldots$ & 44 & 73 & +49 \\
\hline $2 \ldots \ldots \ldots \ldots \ldots \ldots$ & 879 & 248 & -631 \\
\hline …………....... & 498 & 90 & -408 \\
\hline $4 \ldots \ldots \ldots \ldots \ldots \ldots$ & 248 & 89 & -159 \\
\hline $5 \ldots \ldots \ldots \ldots \ldots$ & 31 & 37 & +6 \\
\hline $6 \ldots \ldots \ldots \ldots \ldots \ldots$ & 52 & 72 & +20 \\
\hline $7 \ldots \ldots \ldots \ldots \ldots$ & 691 & 627 & -64 \\
\hline $8 \ldots \ldots \ldots \ldots \ldots \ldots \ldots$ & 509 & 534 & +25 \\
\hline ……….......... & 347 & 345 & -2 \\
\hline …......... & 67 & 95 & +28 \\
\hline ……...... & 66 & 73 & +7 \\
\hline $12 \ldots \ldots \ldots \ldots \ldots$ & 495 & 484 & -11 \\
\hline $13 \ldots \ldots \ldots \ldots \ldots$ & 481 & 502 & +21 \\
\hline $14 \ldots \ldots \ldots \ldots \ldots$ & 435 & 485 & +50 \\
\hline $15 \ldots \ldots \ldots \ldots \ldots$ & 58 & 62 & +4 \\
\hline ……….... & 623 & 374 & -249 \\
\hline ................ & 241 & 191 & -50 \\
\hline $18 \ldots \ldots \ldots \ldots \ldots$ & 31 & 34 & +3 \\
\hline $19 \ldots \ldots \ldots \ldots \ldots$ & 207 & 110 & -97 \\
\hline $20 \ldots \ldots \ldots \ldots \ldots \ldots$ & 430 & 394 & -36 \\
\hline $21 \ldots \ldots \ldots \ldots \ldots$ & 60 & 94 & +34 \\
\hline ………..... & 52 & 83 & +31 \\
\hline $23 \ldots \ldots \ldots \ldots \ldots \ldots$ & 23 & 82 & +59 \\
\hline $24 \ldots \ldots \ldots \ldots \ldots$ & 71 & 98 & +27 \\
\hline $25 \ldots \ldots \ldots \ldots \ldots$ & 36 & 45 & +9 \\
\hline ………. & 34 & 36 & +2 \\
\hline
\end{tabular}

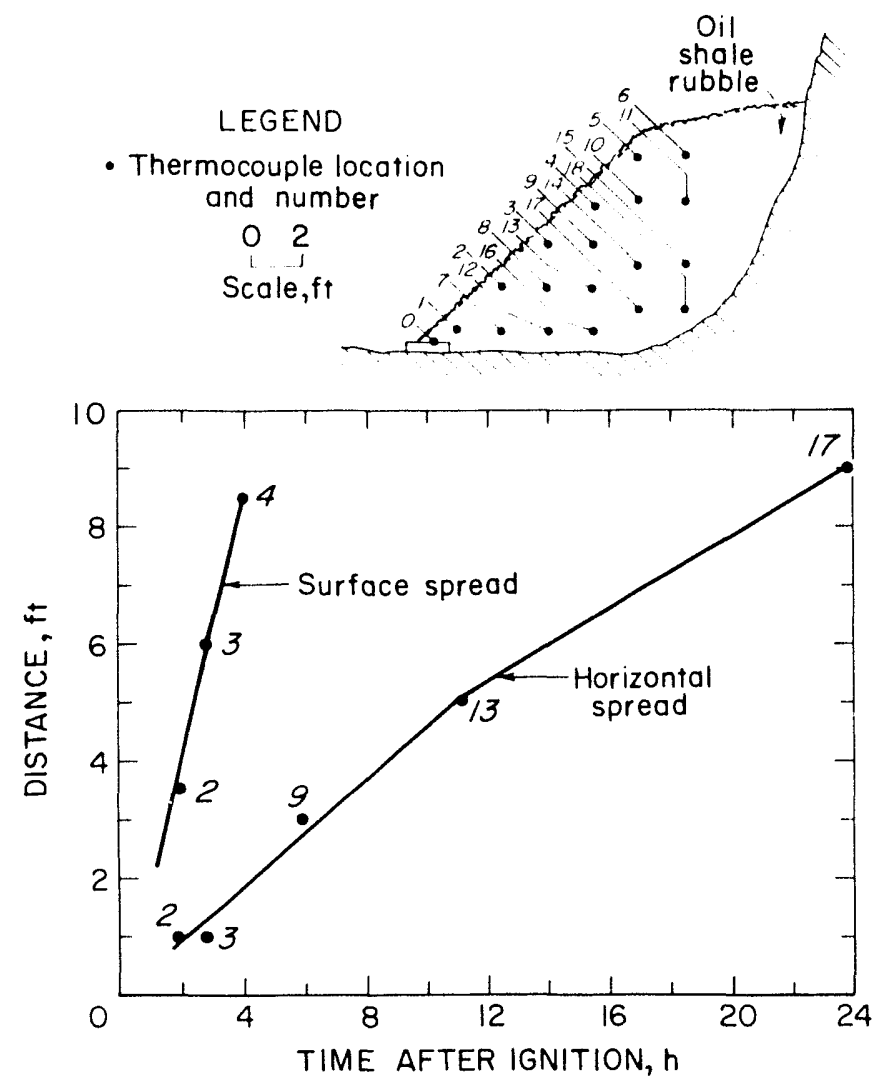

Figure 3-28.-Advance of leading edge of combustion wave in rubble fire 4.

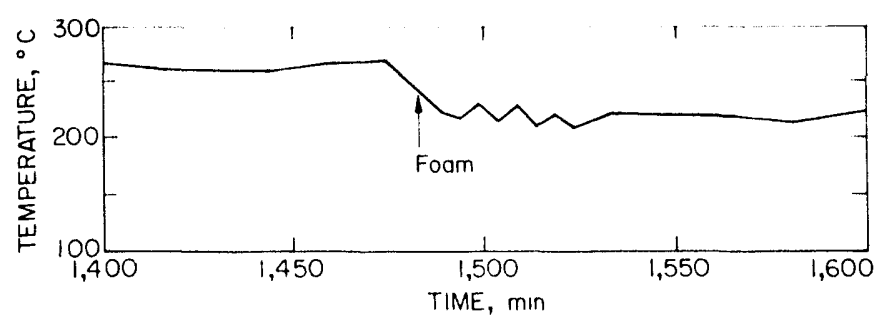

Figure 3-29. -Average pile temperature as a function of time for rubble fire 4 .
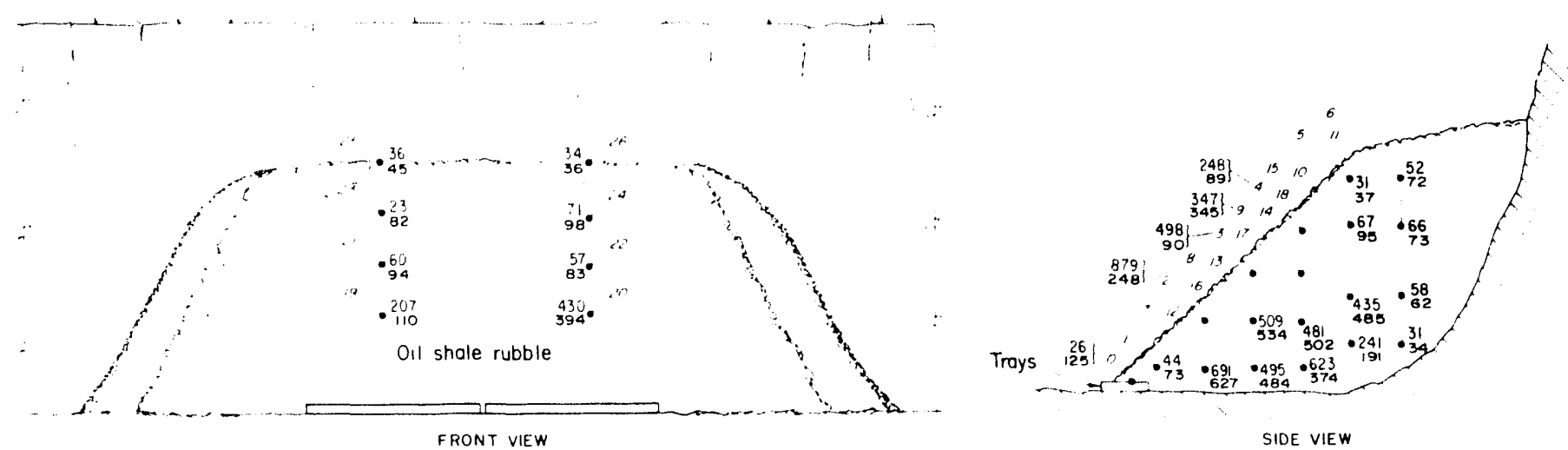

Figure 3-30.-Thermocouple readings before (top number) and after (bottom number) suppression activities with rubble fire 4. 


\section{SUMMARY AND CONCLUSIONS}

\section{SLOW-HEATING TEST}

Oil shale rubble pile 2 was not ignited by the sustained low-temperature source nor was there any indication that the oil shale underwent significant exothermic reaction. Rough estimates indicate that the clectrical energy expended during the slow-heating test totaled about $1.3 \times 10^{9}$ cal, which is enough energy to raise the temperature of the entire 65 -ton pile to over $100^{\circ} \mathrm{C}$. However, only the shale in immediate coniact with the heating source or immediately above the source eve reached temperatures in excess of $100^{\circ}(\therefore$, which indicates enormous heat loss. The theoretical model presented in appendix $A$ suggests that for heat release rates associated with small-diameter oil shale particles the thermal runaway time is relatively short. This prediction is further supported by experimental data from two sources: adiabatic heating experiments and thin-layer studies conducted by the Bureau $(5,7)$ and contract studies conducted for the Bureau (8). Comparing self-heating data for oil shale with that for coal (9) indicates that the self-heating potential for shales is lower than that for volatile, bituminous coal. However, the results of this test indicate that the likelihood of the occurrence of a fire from spontaneous combustion events in run-of-mine oil shale is small.

\section{IGNITION}

Twenty gallons $(75.7 \mathrm{~L})$ of fuel oil was more than adequate to ignite the oil shale rubble fires. Other experiments conducted by the Bureau indicate that as little as 's gal $(1.9 \mathrm{~L})$ of fuel oil is adequate for ignition of sustained combustion in oil shale. Thus, while ignition from low-temperature sources is apparently difficult to accomplish, ignition from hightemperature sources is easy. It follows that the potential fire hazard of this material either underground or in surface facilities cannot be ignored.

\section{EXTINGUISHMENT}

As was previously mentioned, it is difficult to compare the relative effectiveness of the various extinguishing agents used in this series of tests. To compare relative effectiveness requires near-identical fire conditions. Efficiency assumes proper placement of the extinguishant with little or no waste. There was no way of estimating the fraction of extinguishing agent that actually rcithed the seat of the fire compared with the runoff fration. In addition, it was impossible to apply the extinguishing agents in a totally effective manner. There is no doubt that some of the material was wasted on the relatively cool portions of the oil shale rubble piles. Notwithstanding, it is worthwhile to make some attempt at estimating the effectiveness of the various extinguishing agents.

For this purpose, a simple theoretical model using simple heat balance equations was developed for predicting the minimum amount of water required to bring an oil shale pile of arbitrary mass and initial temperature to some lower temperature. The model assumes that the water is utilized with 100 put efficiency, i.e., no runoff and uniform cooling.

The model, which is presented in appendix $B$, can also be used to calculate the temperature reduction associated with the application of a given quantily of water for an oil biale pile of given mass and initial temperature.
One case addressed by the model is that in which the average initial hot shale temperature and the target cooling temperature are both greater than $100^{\circ} \mathrm{C}$. In this situation, the model equates the sensible heat change in the oil shale to the sum of the sensible heat required to raise the water temperature (from the pump value to the boiling point), the latent heat of vaporization of water, and the sensible heat required to raise the steam temperat ure (from the condensation point $-100^{\circ} \mathrm{C}$ - up to the target cooling value).

Another case addressed by the model is that in which the average initial hot shale temperature exceeds $1000^{\circ} \mathrm{C}$ and the target cooling temperature is below $100^{\circ} \mathrm{C}$. In this situation, a two-step transfer process is used. In the first step, the model equates the sensible heat change in the oil shale (from its initial hot shale temperature to $100^{\circ}$ () to the sum of the sensible heat required to raise the water temperature (from the pump value to the boiling point) and the latent heat of vaporization of water. In the second step, the model equates the sensible heat change in cooling the oil shale (from $100^{\circ} \mathrm{C}$ to the target cooling temperature) to the sensible heat required to raise the water temperature (from the pump value to the target cooling value). The total cooling water needed is then obtained by adding the water requirements for the two steps.

Estimated and calculated values of the reduction in average pile temperature associated with the four applications of extinguishment to rubble fire 1 are given in table 3-8.

Table 3-8.-Temperature reduction during suppression of rubble fire 1

\begin{tabular}{|c|c|c|c|c|}
\hline \multirow{2}{*}{ Trial } & \multicolumn{2}{|c|}{ Extinguishant } & \multicolumn{2}{|c|}{ Temperature reduction. ${ }^{\circ} \mathrm{C}$} \\
\hline & Type & Quantity.' gal & Estimated $^{2}$ & Calculated $^{3}$ \\
\hline 1 & High-expansion toam. & 158 & 35 & 19 \\
\hline 2 & Low-expansion foam.. & 372 & 30 & 44 \\
\hline 3 & Water ...................... & 750 & 90 & 87 \\
\hline 4 & do $\ldots$ & 1,750 & 100 & 179 \\
\hline
\end{tabular}

The application of 158 gal (598 L) of high-expansion foam resulted in a reduction of average pile temperature of $35^{\circ} \mathrm{C}$, estimated from figure 3-8. The same quantity of water (158 gal) $\left(598 \mathrm{~L}\right.$.) would have produced a $19^{\circ} \mathrm{C}$ reduction in average pile temperature according to the cooling model in appendix $B$. The small quantity of material applied here and the large error involved in the experimental value of average pile temperature make it difficult to draw a firm conclusion-the highexpansion foam might have had about the same effectiveness as water. The 372 gal $(1,408 \mathrm{~L})$ of low-expansion foam resulted in a $30^{\circ} \mathrm{C}$ reduction in average pile temperature compared with an anticipated value of $44^{\circ}$ ( for the same amount of water. Thus, the low-expansion foam appeared to be about as effective as water. In view of the short life of the foams observed in these experiments, it is unreasonable to expect any temperature decline associated with possible oxygen deprivation; thus, these results are as expected.

The first application of water resulted in an observed reduction in temperatures of $90^{\circ}($, compared with a calculated value of $87^{\circ} \mathrm{C}$, indicating a highly effective application with little runoff. However, the second application resulted in an observed decline of only $100^{\circ}$ (;, compared with an expecied value of $1 / y^{\circ} \mathrm{C}$, indicating either water waste on the cool portions of the pile and or significant runoff. 
Using the cooling model, the total amount of water required to bring the 85 tons of shale in rubble fire 1 from its initial average temperature of $410^{\circ} \mathrm{C}$ (fig. 3.8$)$ to a level below its reignition temperature, which is estimated to be $100^{\circ} \mathrm{C}$, is 3,072 gal $(11,628 \mathrm{~L})$.

This amount is to be compared with a total of $3,030 \mathrm{gal}$ $(11,469 \mathrm{~L})$ of extinguishant used on rubble fire 1 , which resulted in a final average pile temperature of about $200^{\circ} \mathrm{C}$. These observations, coupled with the fact that the pile reignited, indicate that the fire suppression activities with rubble fire 1 were not particularly efficient or effective.

Calculated and observed temperature reduction data for rubble fire 2 are presented in table 3-9.

Table 3-9.-Temperature reduction during suppression of rubble fire 2

\begin{tabular}{|c|c|c|c|c|}
\hline \multirow{2}{*}{ Foam } & \multicolumn{2}{|c|}{ Extinguishant } & \multicolumn{2}{|c|}{ Temperature reduction, ${ }^{\circ} \mathrm{C}$} \\
\hline & Type & Quantity. 'gal & Estimated? & Calculated $^{3}$ \\
\hline \multirow[t]{2}{*}{1} & Ansulite $(3 \mathrm{pct})$. & 2.700 & 140 & 262 \\
\hline & Ansulite (1 pct) .......... & 2.530 & 110 & 141 \\
\hline 2. & Protein $(6 \mathrm{pct}) \ldots \ldots \ldots$ & 160 & 10 & 3 \\
\hline $3 \ldots$ & $\begin{array}{l}50 / 50 \text { medium. } \\
\text { expansion and } \\
\text { Ansulite }(2 \mathrm{pct})\end{array}$ & 1.020 & 50 & 14 \\
\hline
\end{tabular}

The application of 2,700 gal $(10,220$ L) of 3-pet Ansulite foam resulted in a reduction in average pile temperature of approximately $140^{\circ} \mathrm{C}$, compared with the calculated reduction of $262^{\circ} \mathrm{C}$ obtained with the cooling model. Similarly, the second application of Ansulite resulted in a temperature reduction of $110^{\circ} \mathrm{C}$; whereas, based on the cooling model, only 2,530 gal $(9,576 \mathrm{~L}$ ) of water would drop the temperature from its initial value of about 22()$^{\circ} 1070^{\circ} \mathrm{C}$. The combined total of 5,230 gal (19,796 L) of Ansulite (3- and 1-pet) dropped the average pile temperature from its initial value of $350^{\circ}$ to roughly $70^{\circ} \mathrm{C}$ based on the cooling model. Since the pile temperature stabilized at this point, the fire was apparcntly extinguished.

Only minor cooling was effected by the application of the protein foam. Since only a small quantily was applied, no great effect was anticipated. The magnitude of the effect was consistent with expectations for water.

The third application of toam resulted in a further decline in temperature again consistent with expectations for water. However, at this point, the pile temperature was below $100^{\circ} \mathrm{C}$ and the cooling effect was not particularly efficient since the high energy exchange associated with the vaporization of water was not a factor.

Overall it took 6.410 gal $(24,2621$ ) of water-foam to bring rubble fire 2 down from an initial average pile temperature of $350^{\circ} \mathrm{C}$ to approximately $50^{\circ} \mathrm{C}$. The model in appendix $\mathrm{B}$ indicates that 8,707 gal $(32,956$ 1.) of water is capable of accomplishing this same reduction. Thus, it may he concluded that this exercise was a particularly efficient one.

The water for water-foam) requirements for successful extinguishment can be estimated from the fact that a tolal of 6,410 gal $(24,262$ l.) of water-foam was used to quench a 65-ton oil shale fire at an initial average pile temperature of about $3500^{\circ}$ (. This amount equates 10 about $1(0)$ gal ton which is considerably in excess of the 35 gal ton used in rubble fire 1. It is, therefore, not surprising that rubble fire 1 , which had an average pile temperature in excess of $400 \%$ C $C$ prior 10 extinguishment activities, was not brought under control.
Calculated and observed temperature reduction data for rubble fire 3 are presented in table $3-10$.

\section{Table 3-10. - Temperature reduction during suppression of rubble fire 3}

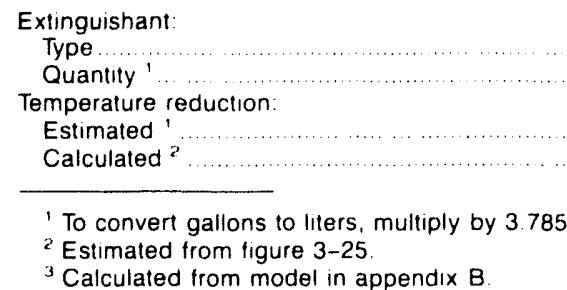

The application of 1,750 gal $(6,624$ L) of water to this rubble fire resulted in a drop in average pile temperature from $260^{\circ} \mathrm{C}$ to about $75^{\circ} \mathrm{C}$ (fig. 3-25). This brought the average pile temperature to below the reignition temperature, and since there were no hot spots (see fig. 3-26), the fire was effectively extinguished. However, calculations show that $1,029 \mathrm{gal}(3,895$ L) is required to drop the temperature from $260^{\circ}$ to $75^{\circ} \mathrm{C}$. Thus, this extinguishing exercise was not particularly efficient.

Calculated and observed temperature reduction data for rubble fire 4 are presented in table $3-11$.

Table 3-11.-Temperature reduction during suppression of rubble fire 4

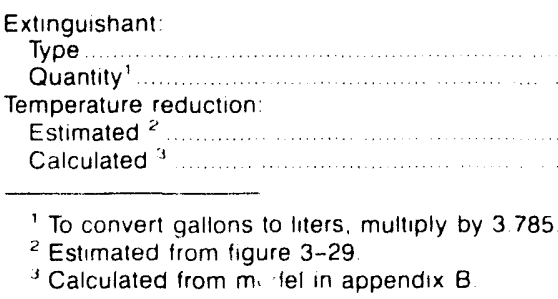

${ }^{3}$ Calculated from $m$, fel in appendix $B$

This application of 600 gal $(2,271$ l.) of the DAP. Ultrafoam combination dropped the average pile temperature from about $270^{\circ}$ to $205^{\circ} \mathrm{C}$ (fig. 3-29), a decline of $65^{\circ} \mathrm{C}$. The model in appendix $B$ indicates that $600 \mathrm{gal}(2,271$ L) of water could produce the same reduction in average pile temperature and that is would take $1,684 \mathrm{gal}(6,374 \mathrm{~L})$ of water to reduce the pile temperature to $1000^{\circ} \mathrm{C}$, below its reignition point. The DAP-Ultrafoam system was the most effective extinguishing agent used in this series of tests because (1) its cooling effect was equal to that expected for water, assuming 100 pet cooling efficiency, and (2) there was only a slight tendency for rubble fire 410 reheat after the application of the extinguishant.

Since the application of 630 gal $(2,385 \mathrm{~L})$ of extinguishing agent 1085 ton of shale averages only 7.4 gal/ton, the high residual temperatures are not surprising. However, most of the final temperatures stabilized at the values shown in figure 3-30. This indicates that the DAP-foam combination may have had an overall inhibiting effect on the combustion reaction. Figure 3-29 show's this trend, which was not rbserved in rubble fire 1 where water was used in the final extnnguishing trials.

\section{KEY FINDINGS}

It was found that baree piles of coarse oil shale could not

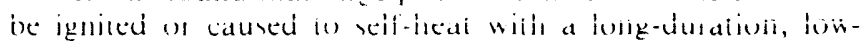
temperature heat source. Failure to ignite was attributed to the 
low self-heating tendency of oil shale, particularly in large lumps, and the high energy losses caused by wind and rain. However, the possibility of spontaneous combustion in oil shale stockpiles cannot be ruled out, especially in the presence of fires.

It was possible to predict with a mathematical model the temperature rise at a fixed distance from a heat source in a rubble pile. The prediction of spontaneous combustion requires more detailed information regarding the particle size effect upon the rate of heat production resultant from the oxidation of oil shale at elevated temperature.

Large rubble piles of oil shale were easily ignited with burning liquid fuels. Any source of flaming combustion must be regarded as a potential ignition source.

Once ignited, oil shale rubble pile lïes became increasingly difficult to extinguish as the fire progressed into the deeper recesses of the pile. foam blankets were not particularly effective in suppressing these fïres because their short lifetime did not allow any significant reduction in heat generation by oxygen deprivation. Low-density foams had better adhesion characteristics and longer life. They would be appropriate for controlling surface flatnes and preventing the spread of fire to unburned portions of rubble piles and possibly the rool and ribs of underground mines.
In general, water was eflective in extinguishing deepseated oil shale fïres but not particularly efficient. It took up to 1.7 times as much water to extinguish a fire as anticipated on the basis of a simple cooling model, assuming 1() pet utilization. Consequently, the water requirements for fighting real oil shale fires may pose supply problems.

One foam-liquid combination, DAP dissolved in water, appears promising. This lire-fighting agent should be further explored for possible application in oil shale and coal firefighting operations. The foam selected, however, should have a significantly long lifetime. Whether such a foam ean be identified is not clear.

Based on these tests, it appears that the best approach to fighting oil shale fires would be to use a low-expansion foam to control surface burning and flame spread, and water or a solution of DAP in water to attack the deep-seated portions of the fire. Experience gained here has shown that the pile temperatures must be lowered to about $10\left(0^{\circ} \mathrm{C}\right.$ to prevent reignition. Since this is the boiling point of water, the disappearance of steam is a good indicator that the fire is out. Additional general comments on fire-fighting strategies are contained in appendix $C$.

\section{REFERENCES}

1. Rusell, P. 1. Histors of Western (Oil Shale. Cent. Prot. Ads., I: Brunsuict. NJ, 1980, $152 \mathrm{pp}$.

2. Breland, R. M., and M. T. Dennehy. Nonfatal Mine Fire Investigation. i.ogan Wash., Occidental Oil Shale, Inc., Debeque, Ciarfield County, CO, reb. 21, 1981. MSHA, 1981, $6 \mathrm{mp}$.

3. Naki, R. (). and W. Synhorst. Report of Nonfatal Mine Fire Accident White River Shale Project. White River Shale Oil Corp., Vernal, Uintah County, UT, Dec. 5, 1983. MSHA, 1983, $4 \mathrm{pp}$.

4. U.S. Mine Safety and Health Administration. Report of Nonfatal Mine Fire Accident Investigation. Logan Wash., Occidemal ()il Shale Inc., Debeyue, (iarfield County, ('), Sept. 12, 1978. 1978, 14 pp.

S. Kuchta, J. M. V. R. Rowe, and D. S. Durgess. Spontaneous Combustion Susceptibility of U.S. Coals. BuMines RI 8474, 1980, $37 \mathrm{pp}$.

6. Crookston, R. B., and M. D). Mc (iuire. An tevaluation of the Fire and Explosions Hazards of Oil Shale Mining and Processing.
Volume 2: Data Summary of Anvil Points Ran Shate Waste Pile Combustion (contract J(1)27500), Iosco (orp.). BuMines OFR 12(2)-85, 1983, 144 pp.; NTIS PB 85-165959.

7. Miron, Y., and ('. P. Iaz/ara. Hire Hazards of ()il Shale Dust layern on Hor Surfaces. Paper in 18 h (Oil Shale Symposium Proceedings (Grand Junction, (O), Apr. 22-24, 1985). (C) Sich. Mines Press, Golden, (O), 1985, pp. 83-1(0).

8. Ciross, S. S. Incorporation of Pire Lxtinguishing Agents in High Expansion loam (contract Ho308064. MSA Res. (orp.). BuMines OI:R 109-83,1983,34 pp.: NTIS PB $83-218859$.

9. Richmond, J. K., M. J. Sapko, and 1. I. Miller. Fire and Explosion Properties of (Oil Shale. BuMlines RI 8726, 1982, $39 \mathrm{pp}$.

10. (iregg, M. I., J. H. ('amphell, and J. R. Taylor. laboratory and Modelling Insestigation of a Colorado ()il-Shale Block Heated to $9(x))^{\circ}$ (. . 1uct, $\therefore$. 60, 1981, pp. 179-188. 


\section{APPENDIX A.-MODEL FOR HEATING AND SELF-HEATING}

Field measurements presented in figure $3-16$ in the main text show that thermocouple 10 ( 1 ft above the drum as shown in figure 3-14) and thermocouple 15 (1 ft away from the drum and toward the high wall at drum height) both showed a thermal response that rapidly followed the temperature of the heated drum. For the major duration of the 55()-h test, the temperature at the surface of the drum exceeded $2000^{\circ} \mathrm{C}$, as shown in figure 3-15. Neither thermocouple indicated that self-heating was occurring-there was no evidence of a thermal runaway. The temperature at thermocouple 10 was higher than at 15 , indicative of the natural buoyancy of the heated air.

A mathematical model was developed to simulate the thermal response at the various spatial and temporal coordinates for an embedded heated drum in an oil shale pile. For simulation purposes, the previously described heat drum was represented by a spherical heat source with a volume equal to that of the cylinderical drum. The drum, which had a diameter of $22 \mathrm{in}(55.9 \mathrm{~cm})$ and a height of 36 in $(91.4 \mathrm{~cm})$, was replaced in the simulation by a sphere with a radius of $14.8 \mathrm{in}(37.7 \mathrm{~cm})$. The pile, with the physical properties listed in table $\mathrm{A}-1$, was treated as a homogeneous isotropic porous bed. Convective airflow and heat production from chemical reactions were not considered. The former was taken as insignificant because the porous consistency of the pile would restrict convection within the pile until temperatures approaching ignition were achieved. The latter did not occur during the heating test.

Table A-1. - Physical properties of oil shale used in models

\begin{tabular}{lrrr}
\hline & Oil shale & \multicolumn{1}{c}{ Air } \\
\hline Thermal conductivity $(\lambda) \ldots . \mathrm{cal} / \mathrm{cm} \cdot \mathrm{s}^{\circ} \mathrm{C} .$. & $1.9 \times 10^{-3}$ & $6.24 \times 10^{5}$ \\
Heat capacity $(\mathrm{Cp}) \ldots \ldots \ldots \ldots \ldots \ldots \mathrm{cal} / \mathrm{g} \cdot{ }^{\circ} \mathrm{C}$. & 0.44 & 0.25 \\
Density $(\mu) \ldots \ldots \ldots \ldots \ldots \ldots \ldots \ldots \ldots \ldots \mathrm{g} / \mathrm{cm}^{3}$. & 2.2 & $1.1 \times 10^{-3}$ \\
\hline
\end{tabular}

For the rubble pile, an effective thermal conductivity, $\lambda_{c}$, was defined by a linear combination of thermal conductivities for air and solid oil shale; i.e.,

$$
\lambda_{c}=\phi \lambda_{i 1}+(1-\phi) \lambda_{b}
$$

where $\phi=$ porosity,

$\lambda_{a}=$ thermal conductivity for air,

and $\lambda_{1}=$ thermal conductivity for oil shale.

The value of $\phi$ for the rubble piles was about 0.46 .

Transient heat diffusion within the spherical pile of radius $R_{1}$ is defined by the heat diffusion equation. The solution to the equation expressed in dimensionless space and time coordinates, respectively denoted as $u$ and $S$, yields a temperature, $\mathrm{T}$, which is a function of $\mathrm{u}$ and $\mathrm{S}, \mathrm{T}(\mathrm{u}, \mathrm{S})$.

The partial differential equation governing the spherical diffusion of heat under the condition of no heat production is given by the equation

$$
\frac{\partial T}{\partial u}=\frac{\partial^{2} T}{\partial S^{2}}+\frac{2}{S} \frac{\partial T}{\partial S}
$$

$$
\begin{aligned}
\text { where } \frac{\partial T}{\partial u} & =\begin{aligned}
\text { first-order partial derivative of } T \text { with respect } \\
\text { to } u,
\end{aligned} \\
\frac{\partial^{2} T}{\partial S^{2}} & \begin{array}{l}
\text { second-order partial derivative of } T \text { with recpect } \\
\text { to } \mathrm{S},
\end{array}
\end{aligned}
$$

and $\frac{\partial T}{\partial S}=$ first-order partial derivative of $T$ with respect

Let $\rho_{\text {a }}$ and $\rho$, be the densities of the air and solid shale, respectively. Let $C_{1}$ and $C_{n}$, be the heat capacities for air and shale, respectively. The temperature field $T$ within the pile at a distance $r$ from the center of the spherical heating source of radius $R$ at a time 1 , denoted by $T(r, t)$, can be related to the temperature field $T(u, S)$ through the transformations

$$
\mathrm{S}=\frac{\mathrm{r}}{\mathrm{R}}
$$

and

$$
\mathrm{u}=\frac{\mathrm{t}}{\mathrm{T}} \text {, }
$$

where

$$
R \leq r \leq R_{1},
$$

and $\quad \tau=\left(\phi \rho_{i} C_{1}+(1-\phi) \rho_{\mathrm{l}} \mathrm{C}_{\mathrm{p}}\right) \mathrm{R}^{2} / \lambda_{\mathrm{c}}$.

In the first phase of the modeling effort, the partial differential equation A-2 was solved numerically using an algorithm implicit in time, in an exponentially stretched coordinate system with spherical symmetry.

The advantage of an exponentially stretched coordinate system is that more information is retained in spatial regions where the temperature field is changing significantly at the expense of regions where the temperature is relatively unchanged, which improves computational efficiency. The algebraically transformed equation A-2 was then written implicitly in time, as a set of coupled finite difference equations using a spatially centered representation of the spatial derivatives. The resultant equations are tridiagonal and are transformed into the upper bidiagonal form by a Gaussian elimination process. The resultant equations are solved for the temperature subject to the appropriate boundary condition, specification of either the temperature or the heat flux, at the surface of the heat source as well as at the surface of the rubble pile.

The temperature of the spherical heating source was determined from a linear regression analysis of the drum temperature shown in figure 3-17 for the time near $50 \mathrm{~h}$. The functional form used for the drum surface temperature, $T$, versus time, $\mathrm{t}$, model is shown in the equation

$$
T_{1}=288.0+162.1\left(1-\mathrm{e}^{4.18} \cdot 10 \mathrm{t}\right),
$$

where $\mathrm{t}=$ time, $\mathrm{s}$,

and $T_{1}=$ surface temperature, $K$.

A computer program was developed to routinely solve the coupled algebraic equations formed from the finite difference representation of equation A-2 subject to the boundary condition at the heating source surface, equation A-7.

The computational procedure yielded the temperature response $1 \mathrm{ft}(30.5 \mathrm{~cm})$ from the source surface shown in the top portion of figure $A-1$ for the no-heat-production situation. The bottom portion of figure $A-1$ shows the surface temperature of the heat source expressed in degrees Celsius. The value of $R$ was 15 in $(38 \mathrm{~cm})$, and $R_{1}$, the outer radius of the oil shale pile. was 53.9 in $(137 \mathrm{~cm})$. The temperature response in figure $A-1$ is in approximate agreement with that 


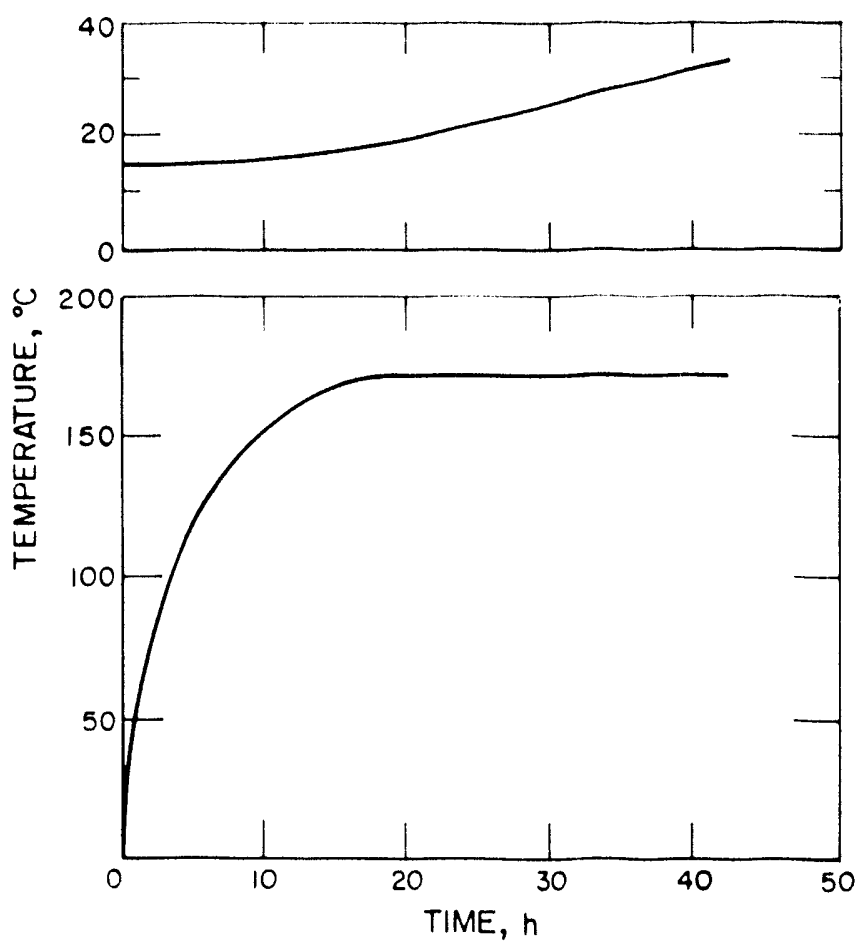

Figure A-1. - Temperature response (top) and drum temperature (bottom).

for thermocouple 15 in figure 3-16. This agrement is expected since at comedion, which was neglected here, mould be less igntifiant sener to the highwalt and at the same level as the heatting drum. It is expected that natural concetion would deselop eloser to the surfite of the pile where air enters dircelly wer the heating drum.

Figure 3- 16 exhibis a rapid cemperature decrease at both tations ahen a power interruption oceurs. This decreatse is cyplatined by the natural contection genterated by the heat source that cominues 10 dram ambient air into the rubble pile while atting as a heal pump. The exrremt model ignores comedtion and predict a time peried of $33 \mathrm{~h}$ for the oil shate at the urfiace to cool from $177^{\circ}$ to $66^{\circ} \mathrm{C}$. The significance of the cooling by contection is made cleat by evaluating the time comsant for a 10 -in-diam $(25.4 \mathrm{~cm})$ oil shale "particle" in ambiem air. Thi, process would oceur if ambient air were comtinuous! supplied to the emironment of the particle.

The diameler of $10 \mathrm{in}(25.4 \mathrm{~cm})$ was selected to represent the larges patricle in a rubble pile. The time constant was determined 10 be $7.9 \mathrm{~h}$, which represents the time for the particke to cool 63 pet of the emperature difference between initial and final (ambient) (cmperatures.

Adiabalic calorimeter measurements were undertaken by the Bureau lo determine the first-order Arrhenius reaction rate parameters for the oil shale oxidation rate. For oil shate with a herogen content weight fratction of 37 gal ton, all actitation

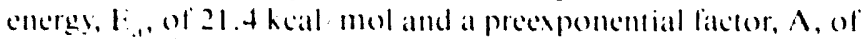
$0.713 \times 10^{10}$ ( s were determined. The mathematical model previously described was modified to prediet the time required for thermal runaway to oceur in a pile of oil shale in which an isothermal heat souree was embedded. The modification of the model comsists of the addition of the heat production ferm (1) equation $A-2$.

let the rate of heat production be denoted as $Q_{1}$, which is given als an Arrhenius reaction rale:

$$
Q_{1}-\rho_{1}, C_{1}, A \text { C } 1, k, 1,
$$

where $R_{y}=$ gats constant,

$$
\begin{aligned}
\rho_{1} & =\text { bulk density, } \\
C_{1} & =\text { bulk heitl capacity, } \\
T & =\text { absolute temperature, } \\
A & =\text { pre-exponential factor. }
\end{aligned}
$$$$
\text { and } E,- \text { activaltion energy: }
$$

The nondimensionalized form of the heat conduction equation A-2. modified to lake into account heat production, yields

$$
\frac{\partial T}{\partial u}=\frac{\partial^{2} T}{\partial S^{2}}+\frac{2}{S} \frac{\partial T}{\partial S}+(1-\phi) \tau A e^{\prime} K_{1} .
$$

In the second phase of the modeling effort, the partial differential equation A-9 was, likewise, solved numerically using an algorithm implicit in time in an exponentially stretched coordinate system with spherical symmetry.

It was determined for a large pile of oil shale with an embedded spherical heat source, maintained at $150^{\circ} \mathrm{C}$, that for heat souree radii greater than $22.2 \mathrm{in}(56.5 \mathrm{~cm})$ thermal runaway would occur after an elapsed time between 28 and 31 h. Whereas, for radii less than 14.8 in $(37.7 \mathrm{~cm})$, considerably longer periods of time would be required as shown in table A-2.

Table A-2. - Thermal runaway

$\begin{array}{cc}\text { Heat source radius, } \mathrm{cm} & \text { Time for thermal runaway, } h \\ 18.85 & 75.7 \\ 28.27 \ldots \ldots \ldots \ldots \ldots \ldots \ldots \ldots \ldots \ldots \ldots \ldots \ldots \ldots \ldots \ldots \ldots \ldots \ldots \ldots \ldots \ldots \ldots \ldots \ldots \ldots \ldots \ldots \ldots \ldots \ldots \ldots \ldots \ldots \ldots \ldots \ldots & 40.8 \\ 37.7 \ldots \ldots \ldots \ldots \ldots \ldots \ldots \ldots & 33.5\end{array}$

These estimates are overly cautious because the selfheating of the oil shale is a surface effect. The adiabatic calorimeter experiments used small-diameter oil shale particles (150 $\mu \mathrm{m}$ or less) with a kerogen fraction of $37 \mathrm{gal} / \mathrm{ton}$. However the actual rubble pile test contained large oil shale lumps and a kerogen fraction of $35 \mathrm{gal} / \mathrm{ton}$, with diameters as great as $10 \mathrm{in}(25.4 \mathrm{~cm})$. The effect of the particle size should be examined more closely using a larger calorimeter to propcrly characterize the first-order kinetics associated with oil shale self-heating. 


\section{APPENDIX B.-MODEL FOR COOLING}

Io shatan an estimate of the minimal water for quenching at rubble pile fire, a heat-exchange model is needed. The model presented here covern three cases: (1) the targed cemperature exceeds 100$)^{\circ} \mathrm{C}$. (2) the hot shale temperature is above $1000^{\circ} \mathrm{C}$ and the target temperature is below $100^{\circ} \mathrm{C}$. and (3) the warm shale temperature is below $1000^{\circ} \mathrm{C}$.

for the heat balances used in the model, the notation used in the three cases is as follows:

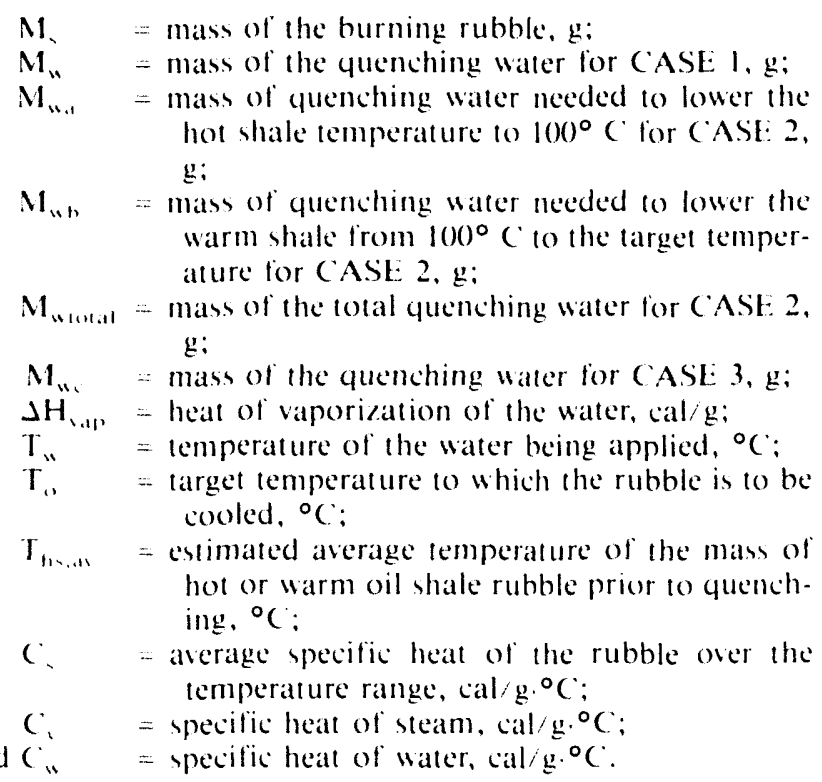

For CASE 1, when the average temperature of the hot oil shale exceeds the target temperature to which the rubble pile is cooled and the target temperature exceeds $100^{\circ} \mathrm{C}$, equation B-2 can be used to compute the minimum water, $M_{n}$.

$$
\text { CASE 1: } \quad \mathrm{T}_{\mathrm{H}, \mathrm{H}}>\mathrm{T}_{11} \geq 100^{\circ} \mathrm{C},
$$

$M_{1}\left(C_{3}\right)\left(T_{H, \ldots+1}-T_{n}\right)$

$$
=M_{n}\left[C_{n}\left(100-T_{n}\right)+\Delta H_{1,11}+C_{1}\left(T_{11}-100\right)\right] \text {. }
$$

For CASE 2, when the average temperature of the hot shate exceeds $100^{\circ} \mathrm{C}$ and the target temperature is below $100^{\circ}$ $C$, either equations $B-4, B-5$, and $B-6$ or equation $B-7$ can be used to compute the minimum water, $\mathrm{M}_{\text {wimal }}$.

CASE 2: $\quad \mathrm{T}_{\mathrm{h}, \mathrm{at}}>100^{\circ} \mathrm{C}>\mathrm{T}_{1,}$,

$$
\begin{aligned}
& M,(C,)\left(T_{11, \ldots, \cdots} \cdots 100\right) \\
& =M_{w a}\left[C_{n}\left(100-T_{n}\right)+\Delta H_{(a \xi}\right] \text {. }
\end{aligned}
$$

$$
\begin{aligned}
& \left.M,(C)(100) \quad T_{n}\right) \quad M_{n 1}\left(C_{n}\right)\left(T_{n} \quad T_{n}\right), \quad(B-5) \\
& M_{w \ldots 1+1}=M_{w_{i t}}+M_{w 1}
\end{aligned}
$$

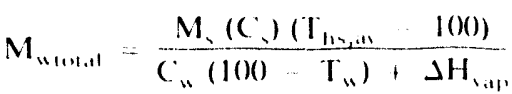

$$
\begin{aligned}
& +\frac{\left.M_{n}\left(C_{1}\right)(100) T_{n}\right)}{C_{n}\left(T_{0} T_{n}\right)} \text {. }
\end{aligned}
$$

For CASE 3, when the warm shale temperature is below $100^{\circ}$ ( and the target temperature is below the warm shale temperature, equation $3-9$ can be used to compute the minimum water, $\mathrm{N}_{\ldots}$.

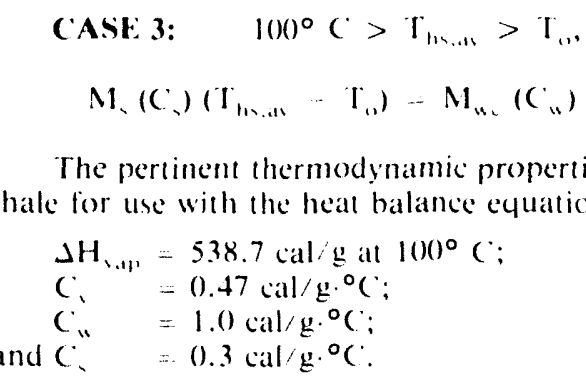

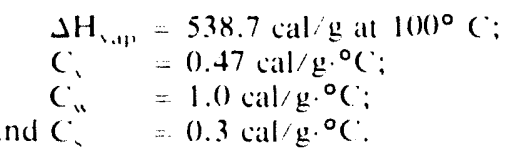$$
M_{1}\left(C_{3}\right)\left(T_{n, \ldots+}-T_{n}\right)-M_{n}\left(C_{n}\right)\left(\Gamma_{n}-T_{n}\right)
$$

The pertinent thermodynamic properties of water and oil shale for use with the heat balance equations are as follows:

To relate the engineering units encountered in the field to those in the heat balances, the appropriate conversion factors are as follows: 1 ton equals $907,200 \mathrm{~g}$, and $1 \mathrm{~g}$ of water equals 2.65 $\times 10^{+}$gal. For the expected range of environmental conditions, the temperature of the water available for quenching, $\mathrm{T}_{\ldots}$. would range between $15^{\circ}$ and $40^{\circ}$ (; i.e..

$$
15^{\circ} \mathrm{C} \leq \mathrm{T}_{n} \leq 40^{\circ} \mathrm{C} \text {. }
$$

Using the heat balance for (ASE 1, minimum gallons of quenching water, $M_{11}$. were computed for various average temperatures of the hot rubble and target temperatures for a 50-ton pile and a water supply temperature of $20^{\circ} \mathrm{C}$. using a value of 0.3 for the specific heat of the shale. These values are presented in table $B-1$.

For the specific heats that demonstrate a linear function of temperature over the appropriate heat-exchange range, when the specific heat assigned is the value at the midpoint of the range, the above heat-exchange model agrees exactly with the rigorous version based on calculus. fortunately, the specific heat data for oil shale indicate linearity with temperature up to at least $9(0)^{\circ} \mathrm{C}(10)$. $^{1}$ The choice of 0.3 for $C$, is on the conservative side.

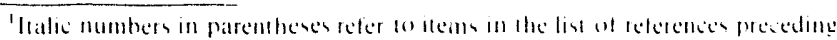
appendix $A$ in part 3 . 
Table B-1. -Minimum gallons' of water for various hot-bed and target temperatures for a 50-ton pile of oil shale

\begin{tabular}{|c|c|c|c|c|c|c|c|c|c|}
\hline \multirow{2}{*}{$\begin{array}{l}\text { Target } \\
\text { temperature } \\
{ }^{\circ} \mathrm{C}\end{array}$} & \multicolumn{9}{|c|}{ Average temperature of pile prior to quenching $\left(T_{\text {nis av }}\right){ }^{\circ} \mathrm{C}-$} \\
\hline & 200 & 300 & 400 & 500 & 600 & 700 & 800 & 900 & 1.000 \\
\hline 190 & 54.6 & 600 & 1.150 & 1.690 & 2.240 & 2.780 & 3.330 & 3.870 & 4.420 \\
\hline 180 & 110 & 659 & 1,210 & 1.760 & 2.310 & 2.860 & 3.410 & 3.960 & 4.510 \\
\hline 170 & 166 & 719 & 1.270 & 1.830 & 2.380 & 2.930 & 3.490 & 4.040 & 4.590 \\
\hline 160 & 223 & 780 & 1.340 & 1.900 & 2.450 & 3.010 & 3.570 & 4.130 & 4,680 \\
\hline 150 & 281 & 842 & 1.400 & 1.970 & 2.530 & 3.090 & 3.650 & 4.210 & 4.770 \\
\hline 140 & 339 & 905 & 1.470 & 2.040 & 2.600 & 3.170 & 3.730 & 4,300 & 4,860 \\
\hline 130 & 399 & 969 & 1.540 & 2.110 & 2,680 & 3.250 & 3.820 & 4.390 & 4.960 \\
\hline 120 & 459 & 1.030 & 1.610 & 2,180 & 2.760 & 3.330 & 3.900 & 4.480 & 5,050 \\
\hline 110 & 521 & 1.100 & 1.680 & 2.260 & 2.830 & 3,410 & 3.990 & 4.570 & 5,150 \\
\hline 100 & 583 & 1.170 & 1.750 & 2.330 & 2.910 & 3.500 & 4.080 & 4,660 & 5,250 \\
\hline
\end{tabular}




\section{APPENDIX C._STRATEGY FOR FIGHTING OIL SHALE FIRES}

Since the carly efforts in oil shale mining. concerns about fire hazards have been raised. The greal loss of life in some underground coal mine fires and the enormous associated property and revenue losses have served as reminders of the need for an effective strategy to prevent and/or combat underground mine and surface fires. The capability of extinguishing an underground or surface mine fire in its early stages is clearly cost beneficial.

Early studies by the Bureau and by the Tosco corp. under Bureau contract suggested possible scenarios relevant to underground and surface oil shake fires. The most common scenarios included surface fïes involving accumulated oil shale in retorts, stockpiles, and railroad cars, and spent shale, as well as underground fires in stockpiles, rubble piles, and crusher bins. Fires involving virgin shale in the rool, rib, and floor were also envisioned. Common ignition sources included spontaneous combustion, diesel fuel, methane ind retort gas flames, hot exhaust manitolds, and burning explosives in blasted rubble.

Despite the low level of production of oil shale to date. unplanned fires have been reported in the Anvil Points Mline in Colorado along the drifts and in the Colony Nine in Colorado during mining and hauling. Fires from secondary ignitions following blasting hate also been reported in the Bureaus Horsedraw Mine in (colorado and at the White River Shale Oil Nine.

At the Bureaus oil thate mine at Horsedraw, when a tunnel had been driven $25 \mathrm{ft}(7.6 \mathrm{~m})$ from the shatt station, the gas emission began to rise. Some of the 2-m-deep blastholes emitted methane. ()casionally, even with the use of blowing vemilation at at rate of $12,0(0)$ (1) 15,000 cfm (340) to 425 $\mathrm{m}^{3}$ mint, in the 10) by (0)-ft (3- by 3-m) drift, mining had to be stoped when the methane in the return air had reached 1 pet.

In November 1978, a methane ignition occurred in the research shaft of the Bureau's oil shale mine at Horsedraw. Al 4:30 a.m. December 6, 1978, at round was fired. Half an hour later, the miners discovered a fire in the much pile. The miners had to retreat to the surface. During the rest of the day and on the nest das, sis separate explosion occurred. due either to explosives being left in the areal or to methane accumulations. The fire had spread to the surrounding ribs and root. The fire was extinguinted by flooding the shath with water.

At the White River ( )il Shale Nine on December 5,1983 , and between June 9 and 12, 1984, ano fires oceurred, which have been altributed to blasting operations. To extinguish the

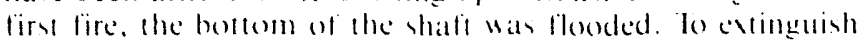

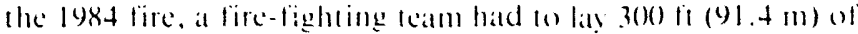
waterline and directl attach the fire with water. The flames were extinguished in aboul 30 min.

With these esamples as batheround, the three essential elements in the srategy 10 combat oit shale tires can be presented. The first element is a presentatise-contingency type of approath, which serven (o) alleviatle mallers should a fire oceur. The exeond is a genteral type of approatch to be implemented immedialely following the delection of a tire

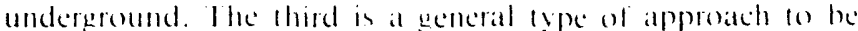
implemented immediately following the detection of a fire on the surface aboseground. The timetrame lon action in the tirs

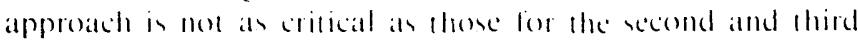
ones.

\section{Prevention Measure and Contingency Planning}

From an analysis of the current strategy emplosed in the coal mining industry-taking into account the important differences between oil shale and coal and the differences in mining practices and techniques-one can identify hey measures applicable to oil shake. For a specitic oil shale mine, the fire prevention, fire-fighting, rescue, and emergency planning measures might involve some of the following:

- Mine design-stopping sites, communication systems, isolation doors, fire detection systems, watter distribution systems, etci:

- Comtingency planning-mine incident and emergency management, ventilation, elc.

- Special teams-rescue, fire-fighting, ventilation control, and gas and particulate analysis;

- Training-rescue, fïre-fighting, smoke control, and gas and particulate monitoring;

- Regular ongoing safety efforts-monitoring the general ventilation network to detect a fire situation, running of waterlines up to the vicinity and cheching the water pressure prior to blasting, monitoring the area following blasting, making periodic and followthrough inspections, having some oxygen self-rescuers readily abailable, and conducting prevenlative maintenance.

Different mines will require different sets of measures. Clearly, the design of an oil shale mine should incorporate special features to prevent fires, to detect fires, to help eontrol ventiation, and to facilitate the fire-lighting. More research should be pursued in order to broaden the choice of possible options available to a given mine.

\section{Underground Fire-Fighting Strategy}

The general strategy for combating underground oil shate fires would seem to include the following steps:

Step 1. Alert the nearby miners and the surfatec coordinator for liere lighting.

Sep 2. Nahe an initial assessment of the heating or open lire situation.

Step 3. lormulate an action planti.

step 4. Withdraw the miners ately from the imperiled areal and send in the resclle and life-fighting leams.

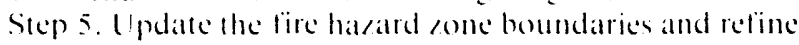
the ation plan.

Sep 6. Fight the open life or heatling.

step 7. Erect the smote control batriers.

step 8 . Isolate the lite working areat.

step 9. (iather the hey data for leathage, fire intensity, heat balance, and explosibility determinations.

step 10. Seal off the tire worhings, if ponsible.

step 11. cool the sealed-off life workings.

sep 12. Monitor the leathage and gals composition for the seidled-offi alleal.

Step 13. Vemtalate the cooled lire workings

seep 14. ()pen and monitor the cooled tire workings.

step 15. Reseal, cool further, and resume the monitoring of the lire working should the lire rehindle.

It should be noted that the latge geometries associated with oil shale mines mathe it difficule to ered seals (even 
low-strength ones) in a short period of time. Smoke control barriers might also be difficult to erect in a short period of time. More research effort on smoke control barriers might prove worthwhile. The large volume of an oil shale mine room makes it difficult to change the gas composition by adding inert gas to the air in a mine having a large total volume of free space. If small portions of a mine could be isolated and leakage kept small, limited inerting might be feasible; however, this would require further study. The economics for inerting does not appear attractive.

Combating a fire immediately following its detection can have a heav'y impact on the probability of success in extinguishing the fire using direct methods. For underground oil shale mines, special concern should be given to methane emissions and blasting in order to develop an effective strategy for the prevention or suppression of a fire. In general, more effort is needed to refine the present strategy for combating underground oil shale fires.

\section{Surface Fire-Fighting Strategy}

For a surface situation, the general strategy for combating oil shale pile fires would seem to include the following steps. data.

Step 1. Monitor the heating or open fire to obtain key

Step 2. Determine, from a heat balance, the minimal water needed for quenching.
Step 3. Formulate an action plan.

Step 4. Secure a water supply and pumps.

Step 5. Construct a dam around the pile, if possible, to permit the recycling of spent quench water.

Step 6. Take precautions against possible steam explosions.

Step 7. Apply quenching water.

Step 8. Alter the pile's configuration following the quenching operation, if possible, by digging out the remaining hot pockets.

Step 9. Monitor the pile following the quenching operation to detect if reheating should occur.

To help control spontaneous combustion in some surface piles, a policy on the height of storage piles should be set and followed. By limiting the height of open storage piles to below a critical value, natural cooling will dissipate the heat from the spontaneous combustion, retard the development of the heating and, it is hoped, avoid a flaming surface situation. Additional efforts are needed to determine the critical height. Its value would seem to depend strongly on the shale's kerogen content, total mass of the shale pile, size distribution of the rubble material, and peak ambient temperature.

In helping to refine the strategy for combating fires in surface retort vessels, recourse can be made to the strategy developed by the chemical processing industry. In general, more research should be devoted to the refinement of the existing strategy for combating surface oil shale fires. 


\section{APPENDIX D._LIST OF SYMBOLS}
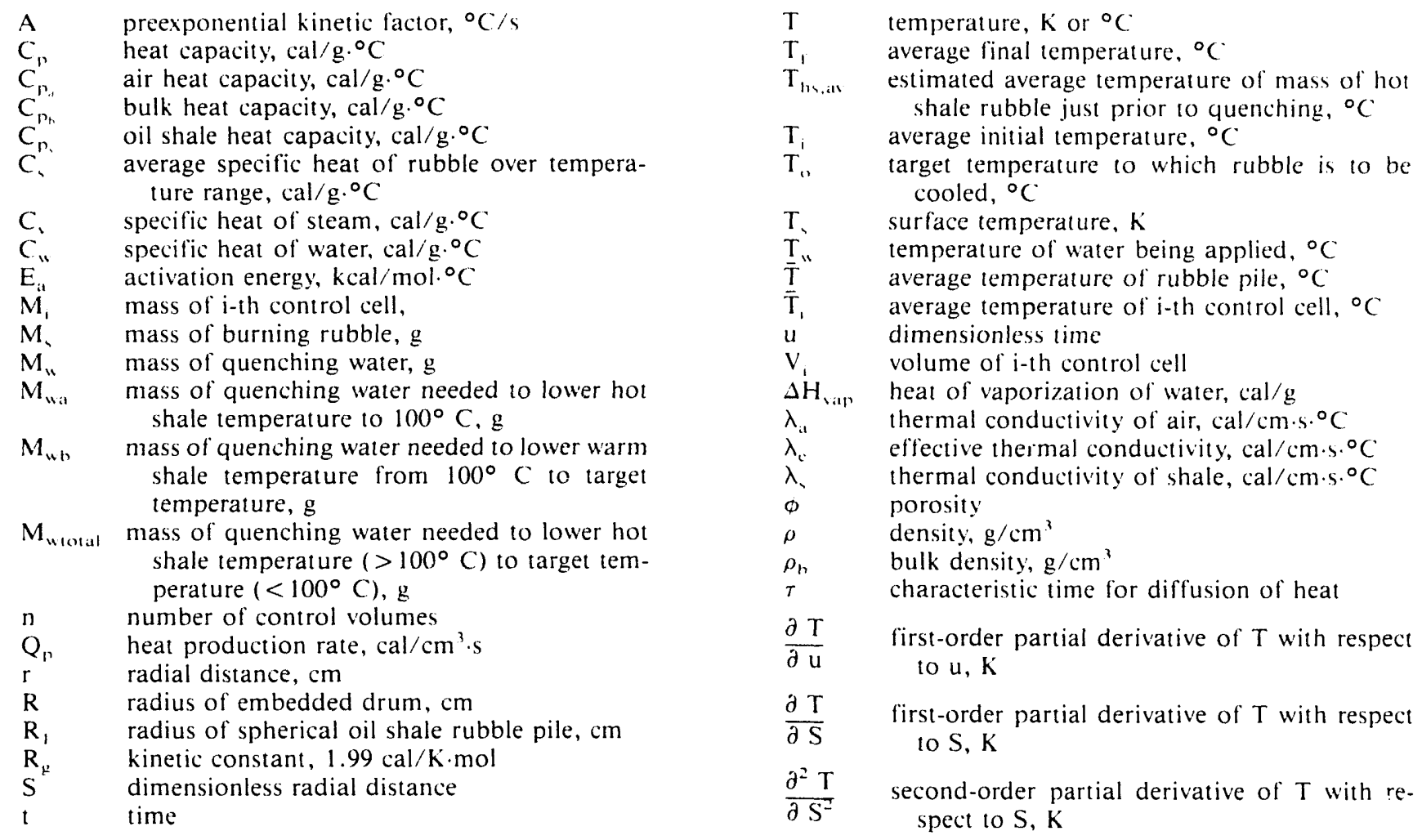

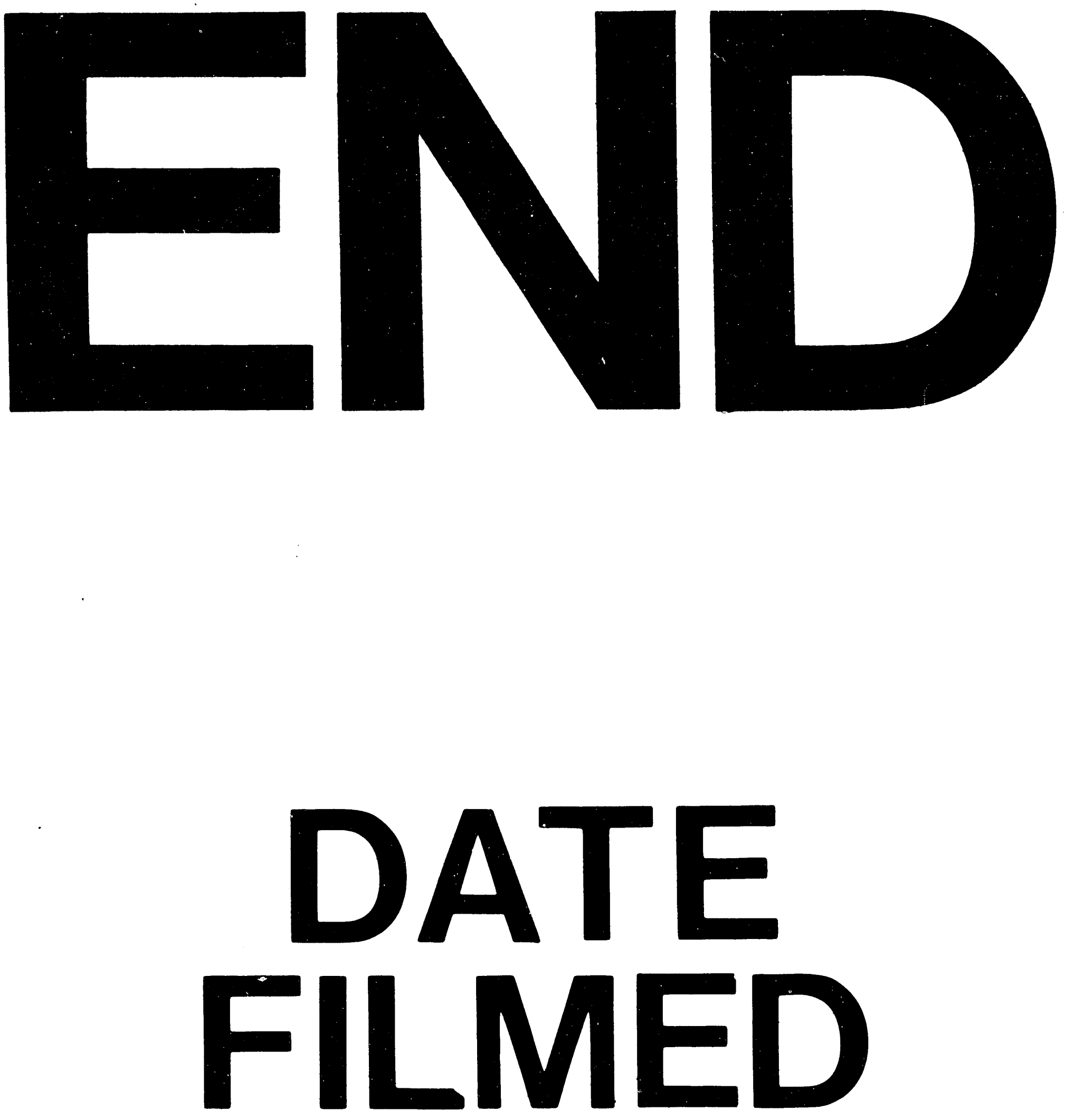

I

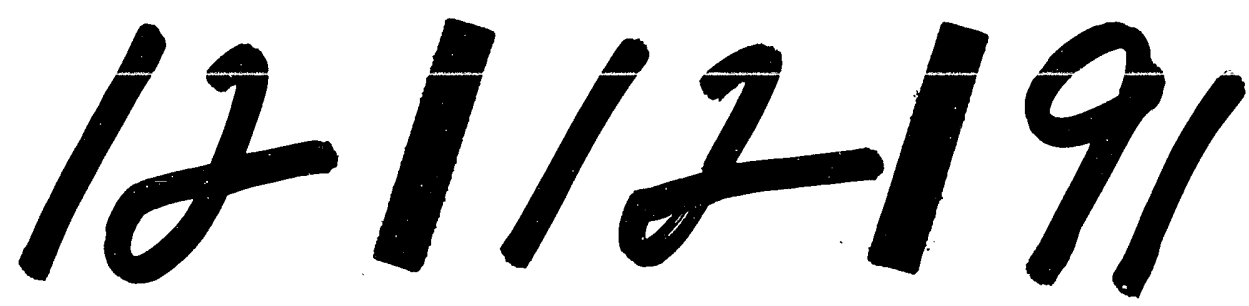


